1994

\title{
Olimpio Pitango De Monalia
}

Eduardo L. Holmberg

Gioconda Marun

Fordham University, marun@fordham.edu

Follow this and additional works at: https://fordham.bepress.com/modlang_facultypubs

Part of the Modern Languages Commons

\section{Recommended Citation}

Holmberg, Eduardo L. and Marun, Gioconda, "Olimpio Pitango De Monalia" (1994). Modern Languages Faculty Publications. 5. https://fordham.bepress.com/modlang_facultypubs/5

This Book is brought to you for free and open access by the Modern Languages and Literatures Department at DigitalResearch@Fordham. It has been accepted for inclusion in Modern Languages Faculty Publications by an authorized administrator of DigitalResearch@Fordham. For more information, please contact considine@fordham.edu. 


\section{EDUARDO L. HOLMBERG \\ OLIMPIO PITANGO DE MONALIA}

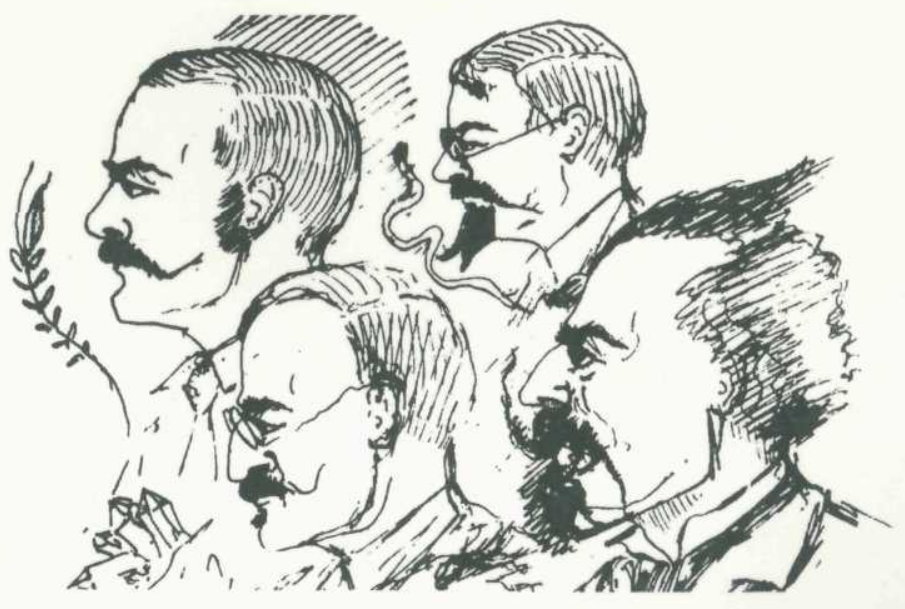

EDICIONES SOLAR 


\section{OLIMPIO PITANGO \\ DE \\ MONALIA}

LA PRESENTE EDICIÓN HA SIDO POSIBLE

POR EL APOYO DEL PROGRAMA REgIONAL DE DESARROLlo CULTURAL QUE EJECUTAN LOS ESTADOS MIEMBROS CON LA PARTICIPACIÓN

DE LA SECRETARÍA GENERAL DE LA ORGANIZACIÓN DE LOS ESTADOS AMERICANOS. 


\section{BIBLIOTECA \\ "DIMENSION ARGENTINA" \\ dirigida por \\ GREGORIO WEINBERG}

\section{SERIE “EDICIONES CRITTICAS"}




\section{EDUARDO L. HOLMBERG}

\section{OLIMPIO PITANGO DE MONALIA EDICIÓN PRÍNCIPE}

Edición, introducción y notas de GIOCONDA MARÚN 
La viñeta de tapa reproduce un fragmento del dibujo de E. L. Holmberg que aparece en la página 91 de esta edición.

Todos los dibujos que aparecen en este libro son del autor y fueron tomados del manuscrito original

\section{ACKNOWLEDGEMENT}

My sincere appreciation to Fordham University for its administrative and financial support through the Faculty Research Fellowship Award (Spring 1991) and the Faculty Research Grant (Summer 1988) which made possible this edition.

Copyright $\odot$ by Ediciones Solar S. A., Alberti 835, Buenos Aires, 1994

Hecho el depósito que previene la ley 11.723 IMPRESO EN LA ARGENTINA - PRINTED IN ARGENTINA 


\section{INTRODUCCIÓN}

\section{CONTEXTO HISTÓRICO DEL TEXTO}

\section{CONFIGURACIÓN DEL INTELECTUAL MODERNO}

El inusual polimorfismo de Eduardo Ladislao Holmberg, que conjuga el hombre de ciencia con el hombre de letras, emerge enmarcado por el concepto del intelectual que está consciente del poder del pensamiento, para lograr transformaciones de orden público. Será el Holmberg intelectual, en una relación de oposición con la estrechez de un medio marcado por concepciones religiosas y morales, el encargado de diseminar una nueva ideología, de sembrar verdades y propagar, junto con los últimos adelantos científicos, el darwinismo.

En Holmberg coexistieron estrechamente unidos el científico y el intelectual, aspectos advertidos por Leopoldo Lugones al comentar su obra Nelly (1896). Aquí Lugones parece adelantarse al resto de los países hispanoamericanos, al usar en 1896 el vocablo "intelectual", tan unido al desarrollo del modernismo: ${ }^{1}$

${ }^{1}$ Aníbal González, que estudia la presencia del intelectual en la novela modernista hispanoamericana, acota: "El sustantivo 'intelectual' no se utilizó en Hispanoamérica hasta los primeros años del siglo XX, en obras como la novela f́dolos rotos (1901), del venezolano Díaz Rodríguez, y la Moral para intelectuales (1909), del filósofo uruguayo Carlos Vaz Ferreira (La novela modernista hispanoamericana [Madrid, Gredos, 1987], p. 28). 
[N]uestro querido sabio Holmberg... escribe con relevante estilo, fluidas prosas y correctos versos, siendo uno de los más completos intelectuales con que cuenta el país de los argentinos. ${ }^{2}$

El concepto del intelectual moderno surgió con el "Manifiesto de los intelectuales" en 1898, a raíz del "affaire Dreyfus", protesta iniciada por Émile Zola, y secundada por todos los hombres de letras y artistas, contra la condena injusta del oficial judío Dreyfus acusado de traidor por los militares franceses. Este concepto, que con el tiempo se ha ido "ampliando", tuvo en su origen el "carácter de acusación y de confianza en el poder público del pensamiento". 3

Quienes iniciaron la tradición del intelectual en la Argentina fueron Sarmiento y Alberdi. Ambos emitieron un discurso cuya autoridad se asentaba en la reflexión histórica social de su época. Fue precisamente el costumbrismo ético-social, que ambos cultivaron como periodistas, Alberdi en La Moda (1837) y Sarmiento en El Progreso (1842), el medio que les permitió iniciar la tarea de civilizar a las masas, de educar al pueblo. ${ }^{4}$

Sarmiento "acuñó la figura del hombre de letras hispanoamericano", al traducirse "en defensa polémica del futuro moderno

${ }^{2}$ Leopoldo Lugones, "Primera edición. Nelly por E. L. Holmberg." El Tiempo, Bs. As., sept. 18, 1896, p. 1, col. 3; el subrayado es mío. En 1900 se le vuelve a aplicar el término "intelectual" a Holmberg, esta vez en ocasión de aparecer como objeto de las caricaturas del célebre Cao, a cargo de la sección Caricaturas Contemporáneas de la revista Caras y Caretas (1900):
A la Historia Natural
con talento excepcional
se dedica horas enteras,
resultando entre sus fieras
otra fiera ... intelectual.

3 Rafael Gutiérrez Girardot, Temas y problemas de una historia social de la literatura hispanoamericana (Bogotá, Cave Canem, 1989), p. 72.

${ }^{4} \mathrm{El}$ costumbrismo ético-social fue el foro de iniciación de la misión de reformadores de la sociedad, al mismo tiempo que representó una toma de conciencia de la necesidad de una lengua americana. Este proceso, que culminó con el modernismo, tuvo en Holmberg a uno de los ejecutores; él no sólo innovó la lengua, sino que agudamente entendió "el conflicto de la lengua" argentina e integró, en Olimpio Pitango de Monalia, los indigenismos y extranjerismos, que dialogaban al unísono en el medio argentino, como lo analizaré más adelante. Acerca de la labor de Sarmiento y Alberdi, como iniciadores de este proceso, véase mi libro: Orígenes del costumbrismo ético-social. Addison y Steele: antecedentes del artículo costumbrista español y argentino (Miami, Florida, Ediciones Universal, 1983). 
y secular" de la Nación, con su Civilización y barbarie. Vida y obra de Juan Facundo Quiroga (1845). Obra que presentó a Rosas como el resultado de la tradición colonial, de la barbarie que oprimía la civilización (Temas y problemas, 67).

La confianza en el poder del pensamiento lo lleva a Sarmiento a denunciar situaciones que deben ser reformadas, e iniciar una tarea de educación y civilización del pueblo, que abarca todos los aspectos de la vida humana, misión didáctica social que tiene como meta el progreso. Sarmiento llena un vacío intelectual al acusar los resabios de la mentalidad colonial que detienen el progreso, y al iniciar el proceso de secularización, ideología liberal puesta en marcha para la organización nacional.

La situación de oposición del intelectual con el medio se repetirá más adelante en Holmberg. Así, mientras Sarmiento opuso a la anarquía e incivilidad el orden y la civilización, Holmberg opuso a la estrechez y beatería del medio el pensamiento racional de la ciencia. Como aquél, las barreras y obstáculos que tuvo que vencer fueron muchos, los que empezaron en 1875 cuando fue nombrado profesor de historia natural en la Escuela Normal de Profesoras. En esta oportunidad fue acusado de "sectario", "ateo" y "materialista", por prohibir terminantemente a la clase la interpretación religiosa o moral de los fenómenos naturales. ${ }^{5}$

La misión didáctica y constructiva, realizada por Sarmiento a lo largo de sus obras, será continuada por Holmberg, agregando a la reflexión histórica del país el estudio del suelo argentino y la divul-

5 Es ilustrativo escuchar a Holmberg contar este hecho: "pregunté un día por qué motivo, al derretirse la nieve o el hielo de las montañas, corrían como líquido por los flancos de las mismas", y las 80 alumnas de la clase de historia natural le contestaron, "Porque así es la voluntad de Dios". Holmberg les respondió: "[s]i el espíritu religioso es tan vehemente entre ustedes, contesten así en la clase de Moral y Religión [...] Y puesto que ustedes desean hacerme creer que las domina un impulso místico, debo prevenirles que eso de manosear el nombre de Dios es un pecado, y para que no se repita ese nombre como capa que sirva para ocultar la ignorancia, prohibo terminantemente nombrar a Dios en mi clase ("Discurso del Dr. Eduardo Holmberg", Homenaje al Dr. Eduardo L. Holmberg, Revista del Centro de Estudiantes de Ingeniería, año XVI, $\mathrm{N}^{\circ} 159$, set. 1915, 735). La presencia de Holmberg dentro de la Escuela Normal de Profesoras fue decisiva: a él se debió la reestructuración y ampliación de los planes de estudios. Cuando él empezó, la asignatura se llamaba historia natural; él la dividió en tres ramas: anatomía, fisiología y zoología, y agregó la higiene y más adelante, en 1877, la física y la química. Todas estas asignaturas fueron enseñadas por él ("Discurso", 734, y Foja de Servicio de Holmberg, redactada por Holmberg el 20 de febrero de 1903 para ser presentada a la Directora de la Escuela Normal de Profesoras $\mathrm{N}^{\mathrm{o}} 1$ de la Capital, en mi archivo). 
gación amena de estas investigaciones. Importante quehacer del intelectual que sienta las bases para el conocimiento de la Argentina. Holmberg llena así otra ausencia en el país: el estudio y la difusión de las ciencias naturales. Aunque fue médico de profesión, se dedicó por entero a las ciencias naturales, a catalogar la flora y fauna de la República Argentina, respondiendo a una necesidad ya advertida por Alberdi. 6

Aunque muchas fueron las barreras, la influencia de Holmberg en el medio fue determinante, no sólo durante sus 40 años de enseñanza y los 15 años de dirección del Zoológico de Buenos Aires, ${ }^{7}$ sino porque fue el difusor más ardiente del darwinismo en el país. Este erigirşe en "conductor de los hombres", consagrado a revelar la verdad de la ciencia, le daría una posición de liderazgo frente al político, destinado "a explotar la ignorancia cobarde y vil", como lo señaló Lugones. 8

Antes de analizar la ideología de Holmberg como intelectual, quisiera detenerme en un aspecto soslayado por la crítica, la estrecha vinculación de Holmberg y Sarmiento, testimonio de una labor de continuidad, en ambos casos ardua y difícil, en favor del progreso y de la modernización del país.

\section{SARMIENTO Y HOLMBERG}

A los pocos meses de la muerte de Holmberg, ocurrida el 4 de noviembre de 1937, uno de sus alumnos, el Dr. Pablo Pizzurno, publicó "Eduardo L. Holmberg como educador. Un aspecto descono-

6 "Nuestra generación [expresa Holmberg], es la destinada a dar impulso a la siguiente, porque realizaremos una opinión manifestada por Alberdi hace treinta años: 'Naturalistas, ingenieros, mecánicos ... eso es lo que necesita la República Argentina'" (Eduardo L. Holmberg, Carlos Roberto Darwin [Bs. As., El Nacional, 1882], 91).

7 Holmberg fue el Director del Jardín Zoológico desde 1888 hasta 1903 cuando injustamente, por razones de índole política, fue exonerado por el intendente municipal, Alberto Casares, por "incompetente". A Holmberg se debió la creación y planificación del actual Zoológico; para ello se inspiró en los diseños de zoológicos europeos y norteamericanos, que reproducían el habitat de los animales (Luis Holmberg, Holmberg. El último enciclopedista [Bs. As., Francisco A. Colombo, 1952], 87-100). Con la remodelación del Jardín Zoológico, Holmberg continúa la obra de Sarmiento, quien lo creó durante su presidencia en el Parque 3 de Febrero.

8 “Discurso del Señor Leopoldo Lugones", Homenaje al Dr. Eduardo L. Holmberg, 730. 
cido de su acción cultural", homenaje del alumno al maestro, que no sólo les enseñó la zoología, la botánica, la mineralogía y la geología, sino que de él aprendieron:

a pensar... a tener ideales, a amar el trabajo, a apreciar la importancia de la observación atenta de las cosas y de los hechos... Nos prevenía contra la ligereza para afirmar lo que no estuviera bien investigado... a desconfiar no sólo de nuestros sentidos sino también de nuestra razón pensando que así como existe el daltonismo físico, puede sufrirse alguna vez de daltonismo moral (La Nación, 11 de enero de 1938).

El artículo ofrece luz sobre otro aspecto de la personalidad de Holmberg, la del maestro que tuvo como maestro a Sarmiento:

Niño mimado de Sarmiento, muy cerca del cual había vivido y crecido; lleno el ambiente del espíritu del prócer, vivo y actuante, Holmberg, influido por él, no podía menos que contemplar, y contempló en sus discípulos normalistas, no a estudiantes comunes sino a futuros educadores del país. 9

Holmberg admite al final de su Foja de Servicio, que la actividad que domina en su vida fue la del Profesor, ya que le sería difícil "determinar cuál de los dos trabajos citados no se vincula con la enseñanza, ya se examinen los de Ciencia pura, ya los de Crítica, y, sobre todo, las Conferencias" ( $\mathrm{s} / \mathrm{p}$ ). Actividad didáctica que lo acerca indudablemente a Sarmiento; 10 sin embargo hay otros lazos de unión que procederé a analizar.

Mucho se ha dicho de que Holmberg fue el encargado de diseminar las ideas de Darwin en la Argentina; indudablemente sus escritos, artículos y conferencias así lo testimonian. Darwin y el darwinismo aparecen tempranamente incorporados en su obra Dos partidos en lucha (1875), mas la presencia de Darwin en el medio intelectual argentino es anterior a la incuestionable misión propagadora de Holmberg.

9 Pizzurno fue probablemente alumno de Holmberg en la Escuela Normal de Varones y en la Facultad de Ciencias de la Universidad de Buenos Aires, en donde Holmberg fue profesor de Botánica desde 1890 hasta 1900 (Foja de Servicio, s/p).

${ }^{10}$ En más de una ocasión vemos el nombre de Sarmiento durante los años de enseñanza de Holmberg: fue nombrado profesor en la Escuela Normal de Profesoras en 1875, siendo Presidente del Consejo de Educación Sarmiento ("Discurso del Dr. Eduardo L. Holmberg", 733); en su conferencia "La misión del maestro" pronunciada en 1880 a los egresados de la Escuela Normal de Varones -Pizzurno era uno de ellos-estaba presente el "General Domingo F. Sarmiento" (Foja de Servicio, 9). 
En el acto organizado a la muerte de Darwin por el Círculo Médico Argentino en 1882, dos personalidades ocuparon la tribuna: el venerable Sarmiento y el joven hombre de ciencia, Eduardo L. Holmberg. En esta ocasión Sarmiento revela que conoció la tripulación del Beagle, a cargo del capitán Fitz Roy, entre la que estaba Darwin, el joven naturalista que observaría y coleccionaría todo lo relacionado con la historia natural:

Pudiera decir señores, que me era familiar el nombre de Darwin desde hace cuarenta años, cuando embarcado en la "Beagle" que mandaba Fitz Roy, visitó el extremo del Continente, pues conocí el buque y su tripulación y desde luego el "Viaje de un Naturalista" [sic] que hube de citar no pocas veces hablando del Estrecho. 11

La expedición del Beagle estuvo anclada en la Argentina entre 1833 y 1834 , realizando viajes exploratorios del suelo argentino en Buenos Aires, Bahía Blanca y la Patagonia,12 aunque parece ser que la circunstancia a la que alude Sarmiento no tuvo lugar en la Argentina, sino en Chile probablemente en 1835. Es Alberto Palcos quien informa sobre este aspecto:

Darwin le preocupa a lo largo de la existencia. Picado por insaciable curiosidad visita de joven en Chile el "Beagle" y se relaciona con su tripulación. ${ }^{3}$

Evidentemente la lectura del filósofo Spencer había preparado a Sarmiento para aceptar el evolucionismo. Así, a los seis años de la publicación de On the Origin of Species by Means of Natural Selection (1859), Sarmiento explicaría un hecho de selección de las especies en el campo argentino mediante la teoría de Darwin:

Admira, de veras, comprobar cómo en 1865 , a seis años escasos de ver la luz el "Origen de las especies", cuando la teoría desenvuelta en sus pági-

11 Domingo F. Sarmiento, Darwin. Sintesis de la evolución del pensamiento laico (Bs. As., Sociedad Luz, 1934), 7.

12 Cuatro fueron las expediciones realizadas dentro del país: "1. El Carmen or Patagones-Bahía Blanca, Aug. 11-17 1833; 2. Bahía Blanca-Buenos Ayres $(400$ m) Sept. 8-20, 1833; 3. Buenos Ayres-Sta. Fe (nearly 300 m) Sept. 27-Oct. 2, 1833; [4]. Captain's expedition up Santa Cruz R. Apr. 18- May 1834" (Charles Darwin, The Voyage of the Beagle, Ed. Leonard Engel [New York, Doubleday \& Co. Inc., 1962], mapa s/p).

13 Alberto Palcos, "Darwin, Sarmiento y Holmberg", La Prensa, 25 de febrero de 1945 , 2a. sec., 1a. col. 
nas está sometida a muy ruda controversia entre los especialistas, Sarmiento además de admitirla cual verdad inconcusa, la emplea para explicar concretamente un hecho observado en nuestro país. Una majada de ovejas que daba cría dos veces al año, empieza a dar tres. Don Domingo inquiere datos desde los Estados Unidos. Se los manda una hermana suya y publica la observación, bajo su firma, en el Boston Daily Advertiser. (Palcos, La Prensa, 2a. col.)

A medida que obtiene más información sobre el hecho, Sarmiento la va enviando al periódico norteamericano, y en una carta a su amiga estadounidense Mary Mann le dice:

Este hecho, fuera de toda duda, viene en confirmación de la teoría de Darwin sobre la selección de las especies (Palcos, La Prensa, 2a. col.).

Con esta experiencia, Sarmiento "se alista entre los defensores del evolucionismo" (Palcos, La Prensa, 2a. col.). En el diario de viaje de New York a Buenos Aires, siendo ya presidente, escribe el 12 de agosto de 1868: "La teoría de Darwin es argentina y me propongo nacionalizarla por Burmeister" (Palcos, La Prensa, 2a. col.). Este concepto, Sarmiento lo volverá a repetir en su discurso sobre Darwin, en 1882:

Le hemos dado, pues, ciencia y fama a Darwin, con los fósiles y las crías argentinas; $y$ siguiendo sus indicaciones, se enriquecen nuestros estancieros.

Me parece que hay motivo suficiente para que seamos los argentinos partidarios de la doctrina del transformismo [...] Hemos constituido una nueva especie: "la oveja argentífera" porque da plata y porque es argentina además (Sarmiento, Darwin, 11).

La idea de "nacionalizar" la teoría de Darwin por el naturalista alemán Burmeister, quien - a sugerencia de Sarmiento- había sido invitado para la dirección del Museo Nacional, por supuesto no se realizó, pues Burmeister no aceptaba el darwinismo. Sarmiento tendrá que esperar a la nueva generación de argentinos, la de Holmberg, no sólo para la propagación del darwinismo, sino para la enseñanza de las ciencias naturales y la formación de discípulos, caras ideas del prócer. ${ }^{14}$

${ }^{14}$ Fue Sarmiento quien facilitó y apoyó la entrada a la Argentina de muchos científicos para que estudiaran el país y difundieran las ciencias. A esto se debe la presencia de D'Orbigny, Burmeister, Bompland, Bravard, Gould, Azara, y que la Argentina, a su vez, tuviera un plantel de investigadores nacionales: Moreno - discípulo de Burmeister-, Ameghino, Zeballos, Lista. 
Holmberg estaba al tanto de la adscripción de Sarmiento al darwinismo. En su "Fantasía científica", Dos partidos en lucha (1875), novela que se desarrolla durante los últimos años de la presidencia de Sarmiento 1872-1874, la teoría de Darwin en Buenos Aires ha enfrentado a dos partidos, enfrentamiento que concluye con la presencia del mismo Darwin. Al arribo de éste a Buenos Aires, se le acercan varias personalidades a saludarlo, entre ellas está Sarmiento a quien Darwin reconoce como a "uno de [sus] más ilustres prosélitos":

El Presidente de la República D. Faustino Sarmiento, extendió la mano al sabio que la estrechó con efusión y le dijo:

— "Tengo el honor de saludar el ilustre reformador inglés..." [...] Darwin que había esperado cinco minutos dijo en castellano bastante claro:

- No es poca mi dicha haber cruzado el Atlántico, para estrechar, al poner el pié en tierra, la mano de uno de mis más ilustres prosélitos americanos, primer magistrado de una gran República!”15

Un cotejo de los discursos de Sarmiento y de Holmberg sobre Darwin revela una gran identificación ideológica. Ambos historian los antecedentes del evolucionismo. Sarmiento demuestra didácticamente cómo el evolucionismo permite explicar fenómenos y

Al respecto, Hicken acota: "Por aquella época, el genio de Sarmiento quiere fortificar la libertad incipiente de la república con el estudio de la naturaleza, única fuente de verdad y justicia; trae de lejanas regiones personas insignes por su saber y cultura, para que ellos esparzan su luz por todos los ámbitos de la joven nación.

Burmeister, Lorents, Gould, Weyhenberg, Hieronymus, Sievert, Stelzner [...] y muchos más, honraron nuestro país con su nombre y sabiduría. Sus producciones, en idiomas exóticos por lo general, son monumentos de método, de meditación y paciencia. Sus libros son conocidos, apreciados y respetados por los especialistas, que los ostentan con orgullo en sus bibliotecas [...] Pues bien, Sarmiento se equivocó; no en la idea, pero sí en los medios. La inclinación de la juventud a las ciencias naturales, esos sabios no la consiguieron. Ellos no dejaron un solo discípulo [...] Holmberg, mientras entregaba a la ciencia los frutos de sus desvelos, esparcía por el pueblo, en lenguaje fácil y festivo, las interpretaciones modernas de hechos vulgares y conocidos" (Cristóbal M. Hicken, Eduardo L. Holmberg y las doctrinas evolucionistas [Bs. As., Imprenta de Coni Hermanos, 1915], 10).

15 Eduardo L. Holmberg, Dos partidos en lucha. Fantasía científica (Bs. As., Imprenta de El Arjentino, 1875), 111-112, el subrayado es mío. Véase el excelente estudio sobre esta obra de Angela Dellepiane, "Ciencia y literatura en un texto de Eduardo L. Holmberg”, en Homenaje a Alfredo Roggiano. En este aire de América (Pittsburgh, Instituto Internacional de Literatura Iberoamericana, 1990), pp. 457-476. 
situaciones de la vida diaria. Holmberg, con un enfoque científico sostenido por un fuerte aparato crítico, se detiene en las contribuciones de la ciencia a la teoría de la evolución, y explica los axiomas de la doctrina de Darwin expuestos en On the Origin of the Species.

Aunque la exposición de Sarmiento está atemperada por su edad, admite que se adhiere a la doctrina de la evolución, "porque necesit[a] reposar sobre un príncipio armonioso y bello a la vez, a fín de acallar la duda, que es el tormento del alma" (Sarmiento, Darwin, 21). Holmberg, que fervientemente proclama que la doctrina de Darwin "nos arrastra, nos envuelve, nos guía" (Carlos Roberto Darwin, 122), está consciente de las limitaciones de la misma:

gran doctrina cuyos principios, adaptados á todas las formas de la actividad humana, deben llevarnos á la perfección, esa perfección tan soñada y que debiéramos haber alcanzado ya, si no fuera indefinida por el progreso, y porque todavía conservamos muchos rastros de nuestro predecesor símico (Carlos Roberto Darwin, 67). ${ }^{16}$

En este pasaje Holmberg, con un juego de palabras que encubre una nota de escepticismo, está transformando el postulado del positivismo "progreso indefinido" - tantas veces esgrimido por el liberalismo económico puesto en funcionamiento por Alberdi, Mitre y Sarmiento- por "indefinida por el progreso". Luego, la doctrina de Darwin permitiría alcanzar la perfección, si no fuera que está "indefinida por el progreso" y por los antecedentes simios del hombre.

Mas los vínculos entre Holmberg y Sarmiento se esclarecen cuando se leen las dos publicaciones de Holmberg sobre aquél. En

${ }^{16}$ El discurso de Holmberg fue malentendido por el medio. Holmberg aclaró muy bien que el eterno problema quedaba insoluble: "Manteniéndonos en los límites estrictos de la observación pura, el problema queda eternamente insoluble.

¿Cuál es el origen de la materia?

¿Es ella eterna? ¿Ha sido creada por un acto de voluntad divina, o ha sido solamente transformada de Caos en mundos definidos, sobre cuyas aguas flotaba el espíritu del Señor ..." (Carlos Roberto Darwin, 24). Más adelante agrega que las Ciencias Naturales pueden usar otros métodos que la observación pura e "inducir" la "eternidad de la materia" (24). Sin embargo el periódico La Ilustración Argentina, que destaca "el fanatismo por Darwin" (317) del discurso, pregunta: "YY el problema fundamental?... y el origen de la vida?... Aquí tenéis amigos, el libro abierto [el de Darwin]. Hacedle la pregunta y sólo quedará en vuestras manos la huella que puede dejar una leve columna de humo" (año II, $\mathrm{N}^{\circ} 27$, sept. $30,1882,318)$. 
1910, a los doce años de la muerte de Sarmiento, Holmberg publica un extenso estudio sobre el prócer en El Tiempo, ${ }^{17}$ y al año siguiente el artículo "Sarmiento" en Caras y Caretas $\left(\mathrm{N}^{\circ} 659\right.$, mayo $28,1911)$, actos de protesta ante "el mamarracho" de la estatua de Sarmiento realizada por Rodin. Holmberg revela un profundo conocimiento de Sarmiento, confiesa haber leído sus obras y sobre todo examinado "sus manuscritos de periodista" (Sarmiento, 35). A través de ellos ha podido extraer "la quinta esencia de Sarmiento", sus tres odios: "España; Rosas; La ignorancia" (20-21). Proyecciones de este prisma son su lucha por la libertad, el progreso y el saber. Aunque concluye que Sarmiento será "el símbolo del talento más grande y del genio más vivo puestos al servicio de la patria Argentina" (67), no deja de reconocer que, "[c]uando se trata de odios, Sarmiento se lleva todo por delante" (28).

Un aspecto sobre el cual Holmberg volverá a insistir en el artículo de Caras y Caretas, es el del "loco Sarmiento", como las caricaturas y anécdotas lo llamaban: "muchas veces se confunde el loco con el hombre inspirado; pero el loco no deja en pos de sí nada estable" (Sarmiento, 41). Este aspecto que Holmberg trataría en muchas obras de ficción, el de la genialidad marcada por aparentes incongruencias, explicaría por qué Sarmiento no fue "un tipo popular" para el pueblo, porque "su obra es demasiado compleja y los pueblos no glorifican sino las entidades simples” (“Sarmiento”, 1a. col.). Más adelante agrega:

Hay que tamizar mucho a Sarmiento.

Y cuando surja radiante la gran figura del patriota, del estadista, del genio, Buenos Aires quedará pensativo, $\mathrm{y}$ hará derribar ese mamarracho de estatua que afrenta su memoria ("Sarmiento", 2a. col.).

Holmberg se identifica con Sarmiento, porque ambos emprendieron una campaña contra el pasado colonial todavía presente, reflexionaron sobre la libertad, y el concepto de república: ${ }^{18}$

17 Este estudio apareció en los números $11,12,15,16,17,18$ y 25 de El Tiempo (oct. 25, 1910). Posteriormente se publicó como libro, Sarmiento (Bs. As., Francisco A. Colombo, 1938), todas las citas en el texto pertenecen a esta edición. Erróneamente Cristóbal M. Hicken afirma que Sarmiento se publicó en El Tiempo en 1902 ("Bibliografía del Dr. Eduardo Ladislao Holmberg por Cristóbal Hicken 1922” en L. Holmberg, Holmberg. El último..., 179).

18 Un cotejo de la ideología de Sarmiento volcada en los periódicos de la época, común a la que expone Holmberg en Olimpio Pitango de Monalia, se realiza más adelante en "Reflexión histórica", apartado 7 de Multiplicidad ideológica en esta Introducción. 
pero los que hemos hecho del estudio de la Libertad y de la República un tema obligado de nuestras meditaciones políticas, tenemos la más profunda convicción de que, entre nosotros, la Libertad y la República han sido la encarnación de la más solemne farsa (Sarmiento, 65).

Aquí están los dos intelectuales, en oposición con el medio que hay que reformar. Mientras Sarmiento realiza la "defensa polémica del futuro moderno y secular" de la Nación (Gutiêrrez Girardot, 67), Holmberg, que continúa la misión progresista de Sarmiento, agrega la difusión de la ciencia fundada en el estudio de la naturaleza para poder combatir la ignorancia que es el arma de la tiranía, y para difundir el conocimiento del suelo argentino. Ambas funciones de estos intelectuales fueron didácticas: la de Sarmiento, didáctica-política; la de Holmberg, didáctica-científica.

\section{IDEOLOGÍA DEL INTELECTUAL}

Holmberg marcó las diferencias entre el especialista que se encierra en su gabinete de investigación, y el intelectual, cuya ilustración proviene no sólo de ser un hombre de mundo, sino de ser un universitario. Asombrosamente él pudo conciliar el entomólogo y el botánico con el intelectual políglota, versado en filosofía, arte y literatura. Todo este saber está expuesto en una gran cantidad de artículos que pululan en los periódicos y revistas de su época, en sus obras publicadas y en manuscritos inéditos que me ha cedido la familia. Para ofrecer un panorama de la ideología que él vuelca en estos escritos, clasifico el material en tres rubros: filología y crítica literaria, arte griego, ciencia y literatura.

\section{FILOLOGÍA Y CRÍTICA LITERARIA}

La Ilustración y el cientificismo del siglo XIX dará como resultado la crítica literaria. Crítica y examen de la obra literaria, intimamente relacionada con la vigorización de los estudios filológicos de fines del siglo XVIII e inicios del XIX. En este despertar, la filología y la crítica se auxiliarán con los métodos de análisis de las ciencias naturales. No es de extrañar que Holmberg incursione en estas dos disciplinas cuya metodología le era familiar por su especialización.

Ilustradores de su profundo interés filológico son sus escritos y conferencias, los que mencionaré brevemente. En el discurso en homenaje al profesor "B. F. Dobranich", considera que la filología 
es "el estudio que mejor sintetiza la evolución humana superior".19 Aquí aludirá a la evolución y lengua de las antiguas civilizaciones, Egipto, China, India, al sánscrito y sus derivaciones.

La inquietud lingüística se materializa más adelante, en la detallada redacción del glosario de argentinismos, criollismos e indigenismos usados en su poema Lin-Calél (1910), que aparece al final del poema. Notas, aclara Holmberg, que para un lector argentino pueden ser "simples curiosidades" pero que muchas veces están revelando la "rica [...] sinonimia" del país, relativa a los nombres de plantas y animales, dificultad que se salva "con los nombres científicos $[\ldots]$ que son universales".20

Le preocupa a Holmberg la disparidad de pronunciación existente entre el habla de los argentinos y de los españoles. Las diferencias de pronunciación española y argentina de la $c$ y la $z$ (preciso y zapato), son consecuencias de particularidades del habla de cada país, aprendidas desde la cuna y acuñadas por el uso: “ ¿Desde cuándo el uso ha dejado de hacer ley en los idiomas?" ("Lo que vale una Y", El Nacional, set. 1, 1887, 4a. col.), precisamente "[u]no de los caracteres fundamentales de lo que podríamos llamar nuestro estilo nacional es la gracia y libertad de la palabra" ("Lo que vale una Y", 4a. col.). Implícitamente en estos conceptos está presente la dualidad lengua y habla, conceptos lingüísticos que empezaron a surgir en Europa con los neogramáticos a mediados del siglo XIX, y que el lingüista suizo Ferdinand de Saussure usaría como base de su teoría. Holmberg distingue entre la lengua, el sistema lexicológico y gramatical que existe como producto social, y el habla, el uso individual del sistema. Al habla de los argentinos pertenecen "veni, tomá, corré", frente a "la magnificencia petulante del vén, tóma y córre" de la lengua ("Lo que vale una Y", 1887, 4a. col.). Mas el objetivo de este artículo, "Lo que vale una $Y$ ", es comentar el cambio introducido por algunos periodistas, de la $y$ griega por la $i$ latina, resultando "lei, rei, soi y do $i$ " en vez de "ley, rey, soy y doy", modificación que pretende convertirse en una reforma en las escuelas ( 3 a. col.). Con respecto a la Academia Española, Holmberg aprovecha la oportunidad de apuntar su ineficaz intento de regular desde España la lengua de los argentinos:

19 “B. F. Dobranich", discurso en homenaje al profesor Balmar F. Dobranich, inédito, en mi archivo. Según Cristóbal M. Hicken, este discurso fue pronunciado en la Escuela Normal de Profesoras, N $N^{\circ}$ 1, en 1912 ("Bibliografía", 168). 309-354.

20 Eduardo L. Holmberg, Lin-Calél (Bs. As., L. J. Rosso y Cía., 1910), pp. 
Aquí, en la República Argentina, son escepcionales [sic] los hijos del país que adoptan sus últimas resoluciones, mientras que los extranjeros, que no alcanzan á comprender lo que podría llamarse el conflicto de la lengua, las aceptan á ojos cerrados.

Y hacen bien.

No conciben un idioma sin reglas (3a. col.).

Holmberg agrega que en sus pocos años ya ha asistido "a cuatro lunas del diccionario y de la gramática" (3a, col.).

Con respecto a la crítica literaria, comentaré en especial La noche clásica de Walpurgis, originariamente una conferencia dada el 28 de julio de 1885 , luego ampliada y publicada independientemente. 21

Aunque el motivo de la conferencia fue el análisis del simbolismo de "La noche clásica de Walpurgis" del segundo Fausto de Goethe, implícitamente está contestando a la crítica que le hizo Miguel Cané, a raíz de la publicación de su obra Dos partidos en lucha (1875).

Conviene esclarecer algunos aspectos de la crítica de Cané, a los que Holmberg alude en su conferencia.22 Miguel Cané parece no aceptar los conocimientos científicos que Holmberg despliega en su obra "que ultrapasan el caudal de conocimientos de aquél que lee" (Cané, 4a. col.):

Es el error, ó más bien, el egoísmo aristocrático de la cultura alemana el orijen de la oscuridad aparente de sus manifestaciones intelectuales. Los alemanes escriben solamente para aquellos á quienes el tecnicismo científico de su lenguaje es tan familiar como para el vulgo el idioma que se arrastra... Y no solamente esa oscuridad, esa generalización agoviadora en la esposición constituyen un obstáculo difícil de vencer, sino que muchas veces es el plan mismo de la obra el que presenta caracteres análogos.

Si Hegel, Kant, Lessing, etc. son inespugnables en el estilo, el segundo Fausto de Goethe es incomprensible en la concepción. El monólogo de Fausto en el aposento de Margarita se lee con delicia, y se pasa como sobre áscuas sobre la noche de Walpurgis (Cané, 4a. col.).

Holmberg confiesa que para "leer el Fausto" decidió aprender el alemán, "y quién sabe si con algún otro motivo también. De ésto hace más de diez años" (La noche clásica, 26, el subrayado es mío).

21 Eduardo L. Holmberg, La noche clásica de Walpurgis (Klassische Walpurgisnacht de Goethe) 2a. ed. (Bs. As., Imprenta de Pablo E. Coni é Hijos, 1887), todas las citas en el texto corresponden a esta edición.

22 Miguel Cané, “'Dos partidos en lucha (Fantasía científica)'. Por Eduardo L. Holmberg", El Nacional, $\mathrm{N}^{\circ} 8.597$, feb. 29, 1875. Las citas se hacen por este artículo, que más tarde sería incluido en Ensayos (1877) de Miguel Cané. 
Si tenemos en cuenta que el artículo de Cané se publicó en 1875, podemos comprender cuál fue el otro motivo.

Holmberg expresa que el segundo Fausto de Goethe no puede ser "debidamente interpretado" ni "criticado" por "un literato que no sepa ciencias, ni por un amante de éstas que no sea literato en toda la extensión" (50). El segundo Fausto refleja tanto al poeta como al sabio: 23

es el lienzo en que estampa las muecas de la vida... es la urna de ágata en que deposita las conquistas de su vasta ciencia, y en la que se unen, á sus estudios de los clásicos griegos, sus investigaciones sobre las metamorfosis de las plantas, sus pesquisas sobre las leyes de la armonía en los colores, sus brillantes inducciones y deducciones de Anatomía Comparada (La noche clásica, 46).

Sin embargo la obra permite una doble interpretación; la primera, es la de ser una "ironía sangrienta contra los sabios pacientes que dedican toda su vida... al estudio de un fenómeno" (La noche clásica, 57). La otra interpretación, mucho más sutil y que no muchos han podido sospechar, queda revelada en una carta de Goethe a Zelter (1826) en la que Goethe admite que la obra está destinada a "resolver una querella". Esta querella - según Holmberg — es "la lucha entre el clasicismo y el romanticismo" (La noche clásica, 62).

\section{ARTE GRIEGO}

Sus estudios de la cultura griega y de su lengua le permitieron no sólo leer los clásicos, sino penetrar en la concepción de belleza reflejada en el arte. La fascinación con el arte heleno no era un secreto. Holmberg tenía en su hogar una réplica de la Venus de Milo, que Correa Morales le trajo de París por intermedio de la casa de Luis Boniche. ${ }^{24} \mathrm{Al}$ pie de esta estatua, Holmberg solía recitar en

23 Aunque la labor científica fue opacada por su fama literaria, Goethe fue uno de los precursores de Darwin: "[F]ue Goethe quien descubrió el protoplasma, ó, para ser más exacto dentro de la verdad histórica, quien concibió esa materia colóide, convertida luego en vesículas y más tarde en organismos superiores" ( $\mathrm{La}$ noche clásica, 34). Holmberg se ocupó de Goethe, como precursor de Darwin, en Carlos Roberto Darwin; según Holmberg, Goethe en Metamorfosis de las plantas (1790), dedujo "que todos los órganos vegetales eran simplemente modificaciones de un órgano fundamental: la hoja". En esta obra ya Holmberg había dicho que Goethe "no sería tan inaccesible para la generalidad, si la generalidad fuera instruida como él" (Carlos Roberto Darwin, 29).

24 Eduardo L. Holmberg, "Actitud de los brazos en la Venus de Milo (Erotófora)", El Nacional, nov. 30, 1889, col. 3-4. 
griego pasajes de la Ilíada, ante la admiración de Rubén Darío y de otros escritores que visitaban su casa. El conocido pintor argentino, José León Pagano, recrea una de estas veladas:

Eduardo L. Holmberg. Un sabio y un espíritu cordial. Fui presentado por Rubén Darío. Cuando me hallé en su presencia, el Dr. Holmberg me tomó de la mano, y como quien guía a un niño, me llevó a la sala. Allí indicándome la Venus de Milo, en magnífica réplica, tamaño del original, me dijo sonriente: así rendimos culto a la belleza en esta casa. Y mientras el taciturno Rubén consentía inclinando la cabeza, el docto señor de la casa comenzó a recitar versos de la Ilíada, en griego naturalmente. ${ }^{25}$

Holmberg escribiría en tres oportunidades acerca de la Venus de Milo. ${ }^{26}$ Se preguntaba por qué la estatua, que había sido encontrada sin brazos, no había podido ser reparada por los artistas, a pesar de haberse intentado en varias ocasiones:

el fracaso de todas las restauraciones de la Venus de Milo (menos una) se debe a una falta completa de estudio de todas sus partes... Para ello no basta el criterio estético: se necesita el criterio científico - si es posible el de la Medicina Legal ("La Venus de Milo", Caras y Caretas, 2a. col.).

Usando el criterio científico estudia los intentos de reproducción de la actitud de los brazos de la Venus, especialmente, la de un escultor ateniense moderno, que después de tres años de estudio, concluye que la Venus sostenía con el brazo derecho un escudo de Marte, apoyado en la pierna izquierda, y con el izquierdo se arreglaba el cabello. Holmberg demuestra que esta interpretación es errónea desde el punto de vista de la fisiología y de la anatomía, 27 y al realizar el estudio de las tres cicatrices de la espalda, "que no las ha producido la acción del tiempo, sino el arrancamiento de algún cuerpo que estaba allí" ("Actitud de los brazos”, La Nación,

25 José Luis Pagano, El arte de los argentinos (Bs. As., Edición del Autor, 1938), 329.

26 “La Venus de Milo (Erotófora). Dos cartas abiertas”, El Nacional, nov. 22, 1889; "Actitud de los brazos. La Venus de Milo (Erotófora). Dos cartas abiertas", El Nacional, nov. 30, 1889; “La Venus de Milo”, Caras y Caretas, $\mathrm{N}^{\circ} 450$, mayo $13,1907$.

27 “ ¿Cómo puede plantar sobre el pie derecho y apoyar el escudo en la pierna izquierda?... Además el arranque del brazo derecho (lo que de él queda) indica que bajaba, y mal podía sostener con él el escudo del dios de la guerra... Ese arranque y la cicatriz considerable del vientre, abajo y a la derecha del ombligo, y oblicuo, señalan... la posición del brazo derecho" ("Actitud de los brazos", 3a. col). 
2a. col.), demuestra que Cupido era ese cuerpo. Leamos la restauración que él propone:

El muslo derecho del hijo de la diosa apoyaba por su cara interna y algo de la anterior en la espalda derecha, quedando la pierna en el aire; el izquierdo descansaba oblicuamente hacia arriba con la cara posterior, pasaba la pierna hacia lo anterior del cuerpo materno por sobre el arranque de que lo que falta del brazo, y quedaba también, en gran parte en el aire ("Actitud de los brazos", 2a. col).

Interesa en esta presentación arqueológica del polifacético Holmberg la conclusión a la que arriba: la importancia tanto en las artes plásticas como en la poesía, de "observar todo con ojos de naturalista, es decir, no apartarse de la fuente universal de la verdad" ("Actitud de los brazos", 3a. col.).

Para Holmberg el arte griego y su literatura son inmortales. Ambos crearon "esa majestad solemne" que Homero transmitiría a la posteridad con la Ilíada y la Odisea, "majestad de dioses que sólo interpretó Esquilo, se humanizó con Sófocles y se degradó con Eurípides" ("La Venus de Milo", Caras y Caretas, 2a. col.).

En otra oportunidad, Holmberg cantó a Homero, a "Él", como lo llamó Aristóteles, el que creó "el idioma del Pensamiento, el lenguaje de la Idea fulgurante é inmortal". ${ }^{28}$ Aquí residiría la superioridad de la literatura griega. A diferencia de lo que pasa actualmente que "sólo se trabaja buscando el efecto", los griegos se preocuparon más por las ideas que por las palabras. Precisa el concepto haciendo suyo el pensamiento de Goethe: "Los antiguos representan la existencia, mientras que nosotros representamos sus efectos" (La noche clásica de Walpurgis, 10). Es por esto que las grandes obras literarias griegas, productos de "la reflexión pura de la Naturaleza", no podrán ser suplantadas por la actual novela francesa de amores libres -la naturalista-que sólo se propone producir efectos, como tampoco el arte griego podrá ser reemplazado por "esa solemne impertinencia que hoy se designa como Art nouveau, hija legítima de la Decadencia en Literatura" ("La Venus de Milo", Caras y Caretas, 2a. y 1a. col.). 29

28 Eduardo L. Holmberg, "Él”, en mi archivo. Según C. H. Hicken, este artículo se publicó en El Magazine, aunque no da fecha.

$29 \mathrm{La}$ idea de que la palabra era un instrumento para ocultar el pensamiento, la expresará en otra ocasión: “;Os están engañando, compatriotas! os están haciendo frases en vez de estátuas; frases en vez de instituciones; frases en vez de crédito; frases en vez de arcas repletas con el oro y la plata de vuestras minas; frases en el mundo político; frases en literatura, en religión y en arte!” (E. L. Holmberg, Sarmiento, 14). 


\section{CIENCIA Y LITERATURA}

En 1989 comenté sobre la fusión de ciencia y literatura en el medio argentino en mi estudio sobre la olvidada Revista literaria (1879), de la cual Holmberg fue uno de los fundadores. 30 Fusión que él inició con sus dos obras, Dos partidos en lucha (1875) y Viaje maravilloso del señor Nic-Nac (1875). 31

La presencia de la Revista literaria, no sólo alumbra una época de la vida de Holmberg que aparece ausente en toda la crítica sobre él, sino que ilumina el nacimiento del modernismo en la Argentina. ${ }^{32}$ La Revista literaria, Órgano del Círculo Científico Litera-

30 Gioconda Marún, “Revista literaria (Bs. As., 1879), una ignorada publicación del modernismo argentino", Revista Iberoamericana (enero-junio 1989), 6388. Aquí Holmberg publicó "El periódico liberal" (1879) y no en 1884, como sostiene Cristóbal Hicken, "en una revista del doctor A. Navarro Viola" ("Bibliografía del Doctor Eduardo Ladislao Holmberg por Cristóbal Hicken 1922”, 177).

${ }^{31}$ En este libro, cuyo subtítulo es revelador, "Fantasía espiritista", Holmberg aplica la cosmogonía filosófica y espiritista del astrónomo francés Camille Flammarion, expuesta esencialmente en La pluralidad de los mundos habitados, libro de gran difusión en Buenos Aires en esa época, de tanteos espiritistas y ocultistas (rica cantera para el modernismo, como lo he analizado en otra ocasión). Este préstamo es admitido por Holmberg al final del Viaje maravilloso del señor Nic-Nac, en "El editor toma un momento la palabra". Aquí expresa que Marte, como la Tierra, puede ser también habitable y que podria estar poblado por seres tan inteligentes como los de la Tierra: "Espíritus brillantes como el de Flammarion sostienen hoy desde el corazón de la Europa, y lo sostienen con todas las potencias de que están dotados, que los otros planetas son habitables, porque en ellos existen todas las condiciones esenciales para la evolución de la vida, y aunque es verdad que no aseguran positivamente que otros hombres recorren sus tierras, admiten por lo menos la posibilidad de existencias análogas" (Viaje maravilloso del señor Nic-Nac. Fantasía espiritista [Bs. As., El Nacional, 1875], 184). Más adelante agrega: "La pluralidad de los mundos habitados no es una fantasía nacida en un cerebro calenturiento, es una necesidad, una conquista del espíritu humano, un homenaje a la grandeza del Universo" (185). Flammarion en La pluralidad de los mundos habitados expone "que los otros mundos planetarios son habitables como la Tierra, y que ésta no tiene ninguna preeminencia marcada sobre los demás" (La pluralidad de los mundos habitados, 4a. ed. [París-México, Bouret, 1907], 24). Apud Angela Dellepiane, "Viaje maravilloso del Señor Nic-Nac: primera novela argentina de ciencia ficción", La Mistica Spagnola. Spagna America Latina. Ed. Gaetano Massa, (Dowling College, 1989), pp. 209-231.

32 El modernismo coincide con una época de nuevas estructuras socioeconómicas y de adelantos científicos. La secularización del siglo XIX, la aparición de la burguesía y la presencia de Darwin, nublarán el optimismo positivista. Factores como la desaparición de Dios, la lucha por la vida, la herencia, el ambiente, cambian las relaciones entre los hombres, y crean una especie de espíritu de crisis, antítesis del exultante optimismo del progreso indefinido. Véase mi libro El modernismo ar- 
rio, ${ }^{33}$ ofrece como novedad la unión de hombres de ciencia y de escritores, nueva generación que incorpora a la literatura los conocimientos científicos más modernos.

Ya en 1852 el pontífice de los parnasianos, Leconte de Lisle, en su "Préface des Poèmes antiques", había propuesto la unión del arte y de la ciencia. ${ }^{34}$ La propuesta se concreta en el modernismo. La ciencia inyecta nueva sangre a esta literatura, nuevos temas, no hollados antes, son explorados, al mismo tiempo que el discurso se hace más sólido y escultórico.

No en vano uno de los Gutiérrez, al escuchar un poema de Holmberg expresa:

¡Qué hermosura! ... Uds., los naturalistas literatos, nos arrebatan a los poetas el privilegio de encontrar las metáforas más novedosas y expresivas! (P. Pizzurno, "Eduardo L. Holmberg como educador", ob. cit.).

Y Leopoldo Lugones, al comentar Nelly de Holmberg, asevera que "la ciencia al avanzar ensancha el campo de las aspiraciones artísticas" al descubrir nuevos horizontes, "ampliación del inmenso misterio universal" que crea para el arte una gran "atmósfera"; así el arte "cree en la ciencia y la respeta" ("Primera edición. Nelly por E. L. Holmberg", ob. cit). 35

Conviene detenernos en las ideas de Holmberg sobre la fusión de ciencia y literatura, expuestas en conferencias inéditas y artícu-

gentino incógnito en La Ondina del Plata y Revista literaria (1875-1880) (Bogotá, Instituto Caro y Cuervo, 1993), donde estudio los orígenes del modernismo en la Argentina en ambas revistas. Aquí analizo a Holmberg como a uno de los primeros cultivadores de esta nueva literatura, con sus cuentos "El ruiseñor y el artista", "El periódico liberal", y sus poemas en prosa.

33 Pertenecían al Círculo Científico Literario: Eduardo Holmberg, Carlos Monsalve, Carlos Olivera, Martín García Merou, Miguel Cané, Adolfo Mitre, Adolfo Navarro Viola, Benigno B. Lugones, Rodolfo Rivarola, Araujo Muñoz, Máximo Riglos, José Nicolás Matienzo, Eduardo Sáenz, Belisario Arana.

34 "L'art et la science, longtemps séparés par suite des efforts divergents de l'intelligence, doivent donc tendre a s'unir étroitement, si ce n'est a se confondre (Charles M. R. Leconte de Lisle, Poésies complètes [París, Alphonse Lemerre, 1927], IV, 211). 35 Como testimonio de esta relación enriquecedora entre la ciencia y el arte, Leopoldo Lugones asevera que "[c]uando Rubén Darío dice que la banda de Iris tiene siete rayos como la lira siete cuerdas, pronuncia una verdad; y más aun: pudo decir científica y artísticamente que la banda de Iris es una lira, una grande y sublime lira, la lira del Sol. El Sol, que es un inmenso cerebro, piensa en colores, y de la concordancia de esos pensamientos nace una armonía: la blanca y bienhechora luz" ("Primera edición. Nelly por E. L. Holmberg"). 
los. En más de una vez, Holmberg propone borrar los límites entre las ciencias y las letras y "establecer una trabazón armoniosa de ambas, de tal modo que el espíritu atento, aunque sea por un instante, confunda los dominios del sentimiento con los dominios de la razón". ${ }^{36}$ En los plebiscitos existentes acerca de la prioridad de las ciencias sobre las letras, en los programas de estudios en las escuelas, triunfan las ciencias, porque "cada día se hacen más patentes sus beneficios, inclusive en las mismas Letras" ("Discurso del Dr. Eduardo L. Holmberg", 740).

El conocimiento de las ciencias ha contribuido a que los humanistas eviten la repetición de errores motivados por la falta de información:

Nuestros compatriotas literatos ya no dicen que el Clavel del aire es una parásita... porque los botánicos verduleros les han enseñado lo que es; los artistas ya no pintan las abejas con dos alas y las moscas con cuatro, porque los zoólogos carniceros les han enseñado que es al revés; ... ya no existen escritores estimados que hablen de abismos sin fondo porque los geólogos picapedreros les han demostrado que eso es un absurdo... "Discurso del Dr. Eduardo L. Holmberg", 740).

Las verdades de las ciencias "han ultrapasado en su vuelo las más estupendas creaciones del talento no servido por ellas" (740). Las teorías de Darwin, no sólo se han infiltrado en los naturalistas y en la enseñanza, sino que iluminan "á la vez las elucubraciones de la Sociología" ("Carlos Roberto Darwin”, Caras y Caretas, s/p). Al explicar científicamente las plagas de Egipto, Holmberg sostiene que las ciencias permiten la interpretación de hechos de la naturaleza, juzgados antes con espíritu místico, al mismo tiempo que auxilian la reflexión y meditación de la filosofía. ${ }^{37}$

Las imágenes de la fantasía "liban en la flor de la Razón" (Las plagas de Egipto, 6), es por esto que los grandes poetas de la historia, son "grandes sabios poseedores de la Ciencia de su época" (740). Éste es el caso de Goethe, a quien Holmberg admira como sabio y como poeta, y de tantos otros como él que han sabido com-

36 “Ciencia y Poesía”, conferencia inédita en mi archivo, pronunciada en El Ateneo en 1893 (Foja de Servicio, s/p), según Cristóbal Hicken esta conferencia fue leída en el año 1896 ("Bibliografía", 167).

37 Eduardo L. Holmberg, Las plagas de Egipto explicadas científicamente (Bs. As., Imprenta "La Vanguardia", 1927), 5, 19. En otra oportunidad Holmberg había pronunciado conceptos similares: " $¥ Y$ la ciencia se ha permitido profanar su misterio, explicándolo! (Carlos Roberto Darwin, 79). 
binar las ciencias con el arte, sin que "la dedicación á la especialidad" haya cerrado "el corazón a los más nobles afectos de patria y familia, y la inteligencia á la contemplación de todas las bellezas de la Ciencia y del Arte" (La noche clásica de Walpurgis, 23).

Toda la obra de Holmberg es un testimonio de la coexistencia en él del científico y del escritor, que según lo exija la obra, primará uno u otro. En la "Nota de Remisión" de su libro Viaje a Misiones, quien habla es el científico:

Si alguna vez un espíritu travieso se ha divertido sobre las páginas, no ha sido sin consentimiento mío, porque el otro espíritu, el que lo mimaba, hacía una vigilancia incesante sobre él. ${ }^{38}$

Aunque Viaje a Misiones es el producto del especialista en ciencias naturales, está escrita —como todas sus otras obras científicascon un lenguaje accesible a todo público: "En este libro (en este tomo) he procurado esquivar, cuanto ha sido posible, el tecnicismo" (15). Y en este intento tenía como maestro a Darwin, cuyos libros popularizaron la ciencia:

¿Por qué se lee con delicia el libro de Darwin Viaje de un Naturalista? Porque se siente la verdad con toda la pureza del hecho estampado en palabras, y revelado al lector con ingenuidad y gracia (Viaje a Misiones, 8).

Holmberg informa que fue durante el siglo XIX, con "la división del trabajo", consecuencia del progreso "en busca de la perfección", que se produjo la división de las ciencias, las artes y las bellas letras, "para llevar a buen término el inventario de sus riquezas y aumentar aisladamente las verdades similares", de cada especialidad ("Ciencia y Poesía", 5). Al dividirse el estudio, cada especialidad creó "su lenguaje propio", ya que debió bautizar "con nombre nuevo cada hecho nuevo" ("Ciencia y Poesía", 6). Es cierto que la pedantería pretenciosa a veces adopta la nomenclatura de la especialidad cuando existe el término vulgar, pero no todos los hechos son vulgares: "[c]uando el músico nos dice moderato, maestoso, andante, allegro, fuga, $[\ldots]$ podremos quizá no entenderle, pero ¿quién nos impide aprenderlo?" ("Ciencia y Poesía", 6).

38 Eduardo L. Holmberg, Viaje a Misiones (Bs. As., Imprenta de Pablo E. Coni é Hijos, 1887), 6. El primer tomo de este libro, fue publicado en el Boletín de la Academia Nacional de Ciencias de Córdoba, t. X, 1887. Un segundo tomo se publicó en 1889. Holmberg fue comisionado por la Academia para hacer estudios científicos en el Norte del país: 1884, Paraná y Santa Fe; 1886, Misiones (Foja de Servicio). 


\section{CRONOLOGÍA}

Para la presente cronología de los hechos esenciales de la vida de Holmberg, se toma como base referencial la Foja de Servicio redactada por él mismo, que obra en mi archivo; la "Bibliografía de la Obra del Dr. Eduardo Ladislao Holmberg" de Hicken; Holmberg el último enciclopedista, libro escrito por Luis Holmberg, el hijo, y el "Estudio preliminar" de Antonio Pagés Larraya a la edición de los Cuentos Fantásticos. ${ }^{39}$ En muchos casos, en lo que respecta a la obra literaria, se ha enmendado la "Bibliografía" de Hicken. ${ }^{40} \mathrm{La}$ vasta producción científica de Holmberg, que ocupa seis hojas de su Foja de Servicio clasificada en zoología, botánica, mineralogía, geología y arqueología, no se menciona en esta cronología. ${ }^{41}$

1852 Eduardo Ladislao Holmberg nace en Buenos Aires el 27 de junio; sus padres: Eduardo Holmberg y Laura Correa Morales

1862-68 Presidencia de Bartolomé Mitre

1872 Terminados sus estudios preparatorios en la Universidad de Buenos Aires, realiza un viaje exploratorio a la Patagonia (Río Negro) y Bahía Blanca. Las colecciones sobre ciencias naturales las regala al director del Museo Nacional de Buenos Aires, Dr. Burmeister

1868-74 Presidencia de Domingo F. Sarmiento

$1874 \quad$ El 18 de julio se casa con Magdalena Jorge

1874-80 Presidencia de Nicolás Avellaneda

1874-76 Oficial primero de la Oficina de Estadística de la Provincia de Buenos Aires

1875-1915 Profesor de historia natural: anatomía, zoología, botánica, cosmografía, geología, como así también de higiene, medicina doméstica, física y química en la Escuela Normal de Profesoras

1875 Publica Dos partidos en lucha y Viaje maravilloso del señor Nic-Nac

1876 Publica "El ruiseñor y el artista" en La Ondina del Plata, y "La pipa de Hoffmann" en El Plata Literario

${ }^{39}$ Antonio Pagés Larraya, "Estudio preliminar”, en E. L. Holmberg, Cuentos Fantásticos (Bs. As., Hachette, 1957), pp. 7-98.

${ }^{40}$ No se incluye en esta cronología todas las publicaciones literarias que aparecieron en periódicos y revistas de la época, lo que se hace más adelante en: Obra Literaria de Eduardo L. Holmberg.

41 Para una información sobre la actividad de Holmberg como hombre de ciencia, véase la "Bibliografía" de Cristóbal M. Hicken (pp. 165-180). 
1877 Enviado por el Consejo de Educación a las provincias del Norte de la República para hacer estudios y preparar colecciones de ciencias naturales

1877-83 Profesor de historia natural en la Escuela Normal de Varones, luego de agricultura, higiene pública y privada

1878 Funda con Enrique Lynch Arribálzaga la revista científica El naturalista argentino

1878 Publicación inconclusa, "El tipo más original" en El Álbum del Hogar

1879 Colabora en la Revista literaria (1879) Órgano de la Sociedad Científica de Escritores, aquí publica su cuento "El periódico liberal"

1879 Publica "Horacio Kalibang o los autómatas" en El Álbum del Hogar

1880-86 Primera presidencia de Julio Argentino Roca

1880 El 29 de setiembre recibe el título de Doctor en Medicina en la Facultad de Medicina. Su tesis doctoral fue sobre El fosfeno. 42

1881 Director del Informe oficial de la Comisión Científica de la Expedición del General Roca a Río Negro en 1879, y redactor de una sección de la parte de zoología de dicho Informe

1882 Miembro activo de la Academia Nacional de Ciencias de Córdoba

1882 Conferencia "Carlos Roberto Darwin" en el Teatro Nacional, publicada como libro el mismo año

1883 Comisionado por el gobierno de la provincia de Buenos Aires para hacer estudios científicos de la sierra de Curá-Malal

1884 Publica "Filigranas de cera" en La Crónica. Holmberg fue uno de los fundadores y el redactor de la sección científica de este periódico.

1884-85 Médico (ad honorem) de la Escuela Normal de Profesoras

1884-86 Comisionado por la Academia Nacional de Ciencias para hacer estudios científicos en Paraná, Santa Fe y Misiones

1885 Jefe de la comisión científica auxiliar enviada a Chaco por el ministro de Guerra y Marina

1886 Publica La noche clásica de Walpurgis; la primera versión de esta conferencia aparece en La Nación en 1885, la 2a. ed. en 1887.

1886-90 Presidencia de Miguel Juárez Celman

1888-1903 Director del Jardín Zoológico.

1890 Miembro académico de la Facultad de Ciencias Físico-naturales y Matemáticas de la Universidad de Buenos Aires

1890-92 Presidencia de Carlos Pellegrini

1892-95 Presidencia de Luis Sáenz Peña

1893 Crea la Revista del Jardin Zoológico, colabora en Caras y Caretas

42 Eduardo L. Holmberg, El fosfeno (Bs. As., Imprenta Ostwald, 1880). 
1894 Enviado en comisión con el doctor Carlos Berg para representar al país en las reuniones de la Sociedad de Agricultura para tratar lo relativo a la filoxera

1895-98 Presidencia de José Evaristo Uriburu

1895 Publica Las plagas de Egipto explicadas científicamente, conferencia pronunciada en 1894 en el Teatro Nacional

1896 Publica La casa endiablada, La bolsa de huesos y Nelly.

1898 Publica "El medallón" en el folletín de El Tiempo

1898-1904 Segunda presidencia de Julio A. Roca

1904-06 Presidencia de Manuel Quintana

1905-10? Inspector de Enseñanza Secundaria 43

1906-10 Presidencia de José Figueroa Alcorta

1910-14 Presidencia de Roque Sáenz Peña

1910

1912

Publica para el centenario argentino el extenso poema Lin-Calél

rar en Fray Mocho

1915 Termina Olimpio Pitango de Monalia

1915 Homenaje organizado por las asociaciones científicas e instituciones educativas al retirarse Holmberg de la docencia, después de 40 años de servicio

1916-22 Presidencia de Hipólito Yrigoyen

1918 Se publica Evolución, capítulo XIX de su Botánica elemental (1908)

1922-28 Presidencia de Marcelo Torcuato de Alvear

1927 Al cumplir 75 años la Academia de Ciencias y la de Medicina lo nombran, respectivamente, presidente y académico honorario. El Concejo Deliberante de la ciudad de Buenos Aires crea el premio municipal anual “Dr. Eduardo L. Holmberg” para el mejor trabajo sobre ciencias naturales, que lo otorga la Academia de Ciencias Exactas Físicas y Naturales

1928-30 Segunda presidencia de H. Yrigoyen.

1930-32 Presidencia de José Félix Uriburu

1932-38 Presidencia de Agustín Pedro Justo

1937 El 4 de noviembre muere Eduardo L. Holmberg

1938 Se publica Sarmiento que apareció en 1910 en El Tiempo

43 Según Pagés Larraya, "En 1905 fue designado inspector de Enseñanza Secundaria" (ob. cit. 23). No he podido confirmar este dato, pero Manuel Gálvez, que lo conoció y dejó su retrato En el mundo de los seres ficticios, informa que Holmberg ya era Inspector cuando él empezó a trabajar también como Inspector de Enseñanza Secundaria, alrededor de 1906. Holmberg "[s]iendo inspector, publicó Lincalel [sic], poema épico sobre las luchas contra el indio. Por su renombre científico, Holmberg daba categoría a la inspección. Me gustaba conversar con él. Su palabra enseñaba y divertía" (Bs. As., Hachette, 1961, p. 27). De esto se deduce que todavía era inspector en 1910, año de publicación de Lin-Calél. Este período de la vida de Holmberg, es importante por su relación con la gestación de Olimpio Pitango de Monalia, como se verá más adelante. 


\section{OLIMPIO PITANGO DE MONALIA}

El 22 de junio de 1927, al cumplir Holmberg 75 años, el periódico La Razón le hace un reportaje. Refiriéndose a Olimpio Pitango de Monalia Holmberg expresa:

De todo lo que he escrito, esto es lo que más quiero. Hace diez años le puse punto final, y no lo he vuelto a tocar, más que para releerlo en mis ratos perdidos. Sin duda no he de publicarlo nunca... ${ }^{44}$

Cuando el cronista, después de escuchar partes de la obra que Holmberg le lee, lo insta a que lo publique, Holmberg responde:

Veremos... puede ser... es que desearía hacer la edición yo mismo, y la impresión de libros cuesta cara (3a. col.). 45

La novela es una descripción de una isla imaginaria, Monalia, en donde en 1912 un sabio escritor, Olimpio Pitango, especie de héroe épico, provoca una verdadera revolución al exponer la necesidad de que su país se organice constitucionalmente para que pueda entrar en el concierto de las naciones más civilizadas, entre las que estaba la Argentina. Su plan de reforma tiende a que la nación tenga héroes, ruinas históricas, partidos políticos, constitución, todo lo que tenían los países más avanzados y que Monalia carecía hasta ese momento. Así fantásticamente se crea una situación falsa, se descubren ruinas históricas, se inventan héroes. La locura de Olimpio Pitango trasciende y la reacción de los países europeos ante este nuevo Don Quijote, inunda Monalia de burlas feroces e ironías. Lo extraño de la situación obliga al gobierno de Monalia a alejarlo del medio. Olimpio es enviado como ministro plenipotenciario a Sud América, pues aquí encontraría todo lo que él había es-

44 "Cumple 75 años en estos días el doctor Eduardo L. Holmberg, prototipo del sabio y del maestro en la Argentina. Una biografía a grandes rasgos, algunos recuerdos y una revelación: en breve publicará su último libro, obra maestra de humorismo, de ironía y de interés" (La Razón, 22 de junio de 1927, col. 3-5, s.p.).

${ }^{45}$ Pagés Larraya, que hizo la edición de los Cuentos Fantásticos en 1957, menciona la existencia de esta obra. Él transcribe parte del reportaje de La Razón en su Estudio preliminar (ob. cit. 50-51) e inclusive cuando comenta otra obra de Holmberg, "El tipo más original" (El Álbum del Hogar, 1878), expresa: "Al mismo género, mezcla de utopismo científico y crítica de costumbres, pertenece su obra inédita Olimpio Pitango de Monalia" (69). 
tado buscando para Monalia. Pero las cartas y reflexiones de Olimpio sobre la Argentina y las demás naciones sudamericanas van iluminando un cerebro sagaz.

El gobierno de Monalia comprende, finalmente, que Olimpio no está loco, cuando él les revela que debió exponer los fundamentos de la reforma "en una forma fantástica y descabellada para una minoría seria y grave... pero imponente y necesaria para una mayoría abrumadora" (164). Su plan de reforma surgió ante la expansión territorial de las naciones capitalistas y las aspiraciones de la alta Banca. Olimpio Pitango previó el peligro de los deseos expansionistas de las grandes potencias; su obra fue una visión de futuridad y así lo pudo entender finalmente el gobierno que lo convirtió en héroe nacional.

A través de dieciséis capítulos se va describiendo la transformación política operada en la isla de Monalia, "paraíso terrenal" no sólo por su clima y vegetación, sino por el ejercicio de la libertad espontánea entre los ciudadanos y la práctica de una democracia perfecta. Monalia sufre el proceso de modernización con todas sus consecuencias, y en este despertar político, va reflejando lo sucedido a las naciones sudamericanas, después de la independencia de España.

La estructura narrativa de la obra permite ser dividida en cuatro partes:

1. Capítulos I-V, descripción de Monalia; fervor político de los habitantes despertado por Olimpio Pitango; contienda periodística entre El Patriota y El Regulador, periódicos de los dos partidos más importantes; descubrimiento de un presunto documento arqueológico; reacción de Europa ante los acontecimientos; Olimpio Pitango ministro plenipotenciario en Sud América.

2. Capítulos VI-XIII, iniciación del proceso constitucional en Monalia; carta reveladora de Tipitambo que descubre los resortes internos de la actitud de Olimpio Pitango; feminismo o el papel de la mujer dentro del nuevo régimen político; el presunto documento arqueológico resulta ser el borrador de un informe médico; carta de Olimpio Pitango describiendo los cánceres de la Argentina; Olimpio regresa a Monalia.

3. Capítulos XIV-XV, Olimpio Pitango es enviado al continente para iniciar una triple alianza de paz y cooperación con Uruguay y la Argentina; reflexión sobre la historia de las naciones sudamericanas; importante presencia de una dama desconocida entre los nin̄os de Monalia, quien logra mantener la atención de ellos con el relato de cuentos. 
4. Capítulo XVI, "La princesa Rayo de Luz", cuento de la dama desconocida expuesto a los niños en el escenario del Teatro Nacional; la dama desconocida resulta ser la madre de Olimpio Pitango; Olimpio Pitango, embajador ante las repúblicas sudamericanas para sostener la doctrina monalita, "South America for the South Americans".

La complejidad temática de Olimpio Pitango desborda los límites de este esquema estructural y le permite a Holmberg reflexionar nuevamente sobre temas y preocupaciones anteriores. Si Olimpio Pitango fue la novela que Holmberg más quería, se debe a que es la obra totalizadora de su actividad creadora. Al participar de toda su vida, es Holmberg en toda su complejidad, en todos sus tiempos.

\section{VISIÓN CARNAVALESCA DE UN MUNDO AL REVÉS}

Por la asombrosa libertad del argumento y por el universalismo filosófico presente, que contempla el mundo dentro de una visión carnavalesca, la novela es una sátira menipea según la define y estudia Bakhtin. ${ }^{46} \mathrm{La}$ sátira menipea fue el género más propicio para la recepción de elementos derivados del carnaval, aparentemente heterogéneos e incompatibles: ideología filosófica y ética, países imaginarios, aventuras fantásticas, violación de normas y de etiquetas, multiplicidad de géneros y de discursos. Elementos estrechamente integrados en un principio unificador: el sentido carnavalesco del mundo.

Olimpio Pitango es el héroe que encarna la invención temática: la necesidad de que Monalia tenga historia, se organice constitucionalmente. Esta idea origina las más disparatadas circunstancias por medio de las cuales el héroe pierde su unidad épica al ser tildado de loco, para luego recuperarla bruscamente después de su sabia actuación en los países extranjeros. Contribuyen a esta visión carnavalesca característica de la sátira menipea las situaciones extremas y ridículas presentes en la novela - las distintas interpretaciones paleográficas, la invención de héroes y de documentos históricos - la pluralidad de discursos opuestos, y la multiplicidad de géneros. Tono múltiple y dispar, integrado como en el

46 Los efectos que las festividades y ritos del carnaval tuvieron sobre la literatura constituyen para Bakhtin la carnavalización literaria (M. M. Bakhtin, Problems of Dostoievsky's Poetics [Minnesota, University of Minnesota, 1984]. Hay edición en español: M. Bakhtin, Problemas de la poética de Dostoievsky, México-Bs. As., Fondo de Cultura Económica, 1986.) 
carnaval, para crear la representación de un mundo al revés, el de la civilización actual.

Es posible seguir en OPM los caracteres definitorios de la sátira menipea elucidados por Bakhtin, ${ }^{47}$ que procederé a puntualizar.

Un epígrafe en francés encabeza la primera página del manuscrito firmado por L. K., iniciales aclaradas al final de la página, cuando después de un comentario que sigue al epígrafe, firma Ladislao Kaulitz, uno de los seudónimos de Holmberg. 48 Es importante detenerme en esta página, sin enumerar, por su significado interno. El epígrafe en francés reza:

On vend l'inmeuble connu sous le nom de Paradis terrestre avec ses lions. On a fait courir le bruit qu'un des chiens a disparu pendant la nuit dernière, mangé peut-être par un des vieux lions. C'est inexact. Le chien est caché dans un trou de la véranda, pour soigner la petite fille qui va y dormir ce soir comme un garantie de l'inexpérience des lions pour toutes espèces de chairs. Ils ne mangent que du riz. L. K. $(73)^{49}$

La primera idea presente aquí es la de caos y desorientación que invade el "paraíso terrestre". En la novela, Monalia, "paraíso terrestre" que vive "la paz de la edad de oro" (83), pierde, con el despertar político-institucional, todos los beneficios experimentados hasta ese momento: la justicia, el orden, el bienestar, la felicidad, el respeto de las naciones (104). Por otro lado, este proceso es además un reflejo de otros similares vividos por las naciones sudamericanas ante los deseos expansionistas de las naciones extranjeras, "los leo-

${ }^{47}$ Bakhtin, ob. cit., pp. 114-134.

${ }^{48}$ En realidad Holmberg ha usado en otras publicaciones el nombre Ladislao Kaillitz. En Dos partidos en lucha (1875), él se incluye como personaje de la obra con este nombre. Ladislao Kaillitz es el seudónimo de sus obras "La ciudad imaginaria" (La Crónica, abril 14, 1884). "Filigranas de cera" (La Crónica, abril 7, 1884). En "El tipo más original” (ob. cit.), Ladislao Kaillitz es uno de los personajes. Llama la atenciôn que en OP utiliza la forma Kaulitz, que se repite contemporáneamente, en 1913, en "Un fantasma" ( $L a$ Cruz del Sur, ob. cit.), en este relato, que proporciona importante información acerca de su niñez, Holmberg habla de su "apellido eslavo Kaulitz" y cómo "la terminación "itz" lo tuvo "mucho tiempo intrigado" (327). Según Luis Holmberg, el abuelo de Holmberg fue Eduardo Kannitz, barón de Holmberg, quien actuó en las guerras de la Independencia argentina. El apellido apareció indistintamente escrito en el medio argentino, Kanitz, Kaunitz, Kammitz, Kaillitz e incluso Kaulitz (Luis Holmberg, Holmberg. El artillero [Bs. As. Francisco A. Colombo, 1946], 31). Holmberg, en sus obras, no está haciendo nada más que repetir las distintas versiones que circulaban de su apellido Kannitz.

${ }^{49}$ Los números entre paréntesis después de cada cita corresponden a la paginación del texto en esta edición. 
nes" que pretenden comer sólo “arroz". Por lo tanto Monalia representa el microcosmos de otro mundo al revés, el macrocosmos mundial que en esos momentos vive la iniciación de la Primera Guerra Mundial (1914-15), en la que otros "leones", las potencias extranjeras, tampoco se alimentan sólo de "arroz". Olimpio Pitango alude a esto en el texto, cuando justifica su modo de actuar ante su gobierno:

Era necesario que Monalia fuese apta igualmente como nación, ya que lo eran todos sus ciudadanos. Él no tenía confianza en la buena fe de los leones sino cuando los leones carecen de colmillos y de garras, que es cuando no sirven para nada (169).

Valiéndose de una multiplicidad ideológica y genérica, la novela desarrolla un universalismo filosófico que completa la visión carnavalesca del mundo. Ruptura del orden establecido, lograda a través de la incorporación de elementos dispares y opuestos, como se observa en el párrafo que sigue al epígrafe francés:

Cuando Goethe experimentaba la necesidad de escribir, no siempre encontraba a mano una cantidad homogénea de papel, y se valía de sobres, reversos de cartas y aún de hojas de envoltorio. En esa misma época, predominaba el papel de hilo con más o menos rayas de aguas, que también se usaba en las imprentas, y que más de una vez, utilizando libros impresos, se han pitado los lectores a falta de chalitas.

En el momento actual nos sobra el papel homogéneo. Lo que nos hace falta son los hombres que piensan como Goethe.

Lector: elige entre el papel y el pensamiento.

Ladislao Kaulitz (73)

Este párrafo, que concluye la primera página, anticipa la doble visión que Holmberg ofrecerá en la obra: la necesidad de unidad de los países hispanoamericanos ante el imperialismo extranjero no cancela la diversidad cultural, sino que por el contrario está proclamando que la unidad de Hispanoamérica reside precisamente en su variedad. Pluralidad cultural, producto de la fusión de lo indígena y lo nacional con lo extranjero, que se manifiesta en un discurso heteroglótico. Heteroglosia que asienta la convivencia de indigenismos, de hablas rurales, regionales, de distintas normas sociales.

En el párrafo arriba citado, los americanismos pitado (pitar, fumar) y chalitas (chala del quichua challa, hoja que recubre la mazorca del maíz), están exaltando la pluralidad lingüística de Hispanoamérica y al mismo tiempo destruyendo la separación en- 
tre dos códigos lingüísticos que funcionaron en el siglo XIX separados: el de la cultura culta y el de la popular.

Por otro lado, la mención de Goethe en el párrafo, asienta un concepto ya desarrollado por Holmberg: la importancia de las ideas sobre las palabras. Goethe es el admirado autor, fusión del científico con el escritor, cuyo lenguaje - como el de los griegoses el del pensamiento, el de la idea, y no el de la palabra que sólo intenta lograr efectos.

En conclusión, por los contenidos descifrados, esta primera página funciona como metáfora de la novela, al apuntar a significados claves presentes a lo largo de la misma.

Usando los conceptos de Bakhtin, distinguiré en la novela la heteroglosia en el lenguaje, la multiplicidad de géneros y de ideas. Elementos que permiten ubicar la obra en los orígenes de la vanguardia, por la conciencia de la coexistencia de una pluralidad de voces y de culturas en Hispanoamérica. ${ }^{50}$

\section{HETEROGLOSIA EN EL LENGUAJE}

La heteroglosia ${ }^{51}$ en el lenguaje se manifiesta no sólo en la incorporación en el discurso de las voces de distinto nivel cultural registradas ya arriba, sino en la inserción de lenguas extranjeras que dialogan al unísono con los indigenismos y populismos. Las lenguas extranjeras presentes son el latín, el francés y el inglés. El libro se abre con el epígrafe en francés ya comentado. Algunas de las citas en latín, como "Si vis pacem para bellum" (156) y "In hoc signo vinces" (115) forman parte del acervo cultural. Otras como "ad referendum" (166) y "laurorum genitrix" (147), son latinismos aceptados por la norma culta e integrados al discurso. A veces se intercala "un latinajo" o un "latín de cocina" (143), como sucede con la interpretación en latín que recibió el recorte de papel encontrado por el paleógrafo Ñanga Pichanga, que analizo en el apartado siguiente.

De las tres lenguas, el inglés es la menos frecuente, aunque Holmberg la usaba mucho pues había traducido varias obras del

${ }^{50}$ Apud Ana María Barrenechea, "El español de América en la literatura del siglo XX a la luz de las teorías de Bakhtin", Actas del II Congreso Internacional sobre el español de América. Ed. José G. Moreno de Alba (México, Facultad de Filosofía y Letras, 1986), 11-21.

51 Sobre el concepto de heteroglosia, véase M. M. Bakhtin, The Dialogic Imagination (Austin \& London, University of Texas Press, 1981), 263 y ss. 
inglés. $52 \mathrm{El}$ inglés está marcando el discurso con los vocablos "market", "lectures", "starting" (97) y la expresión "They say so, but they don't mean it" (161).

Algunas veces el discurso registra los extranjerismos que ya han adquirido carta de ciudadanía, como la palabra francesa "claquer" (97) y la expresión "pour la galerie" (176), que se usa todavía en la lengua coloquial del porteño y alude a aquellas cosas que se hacen para engañar o halagar a alguien.

La heteroglosia del lenguaje señala otras veces la ruptura de las normas sociales del discurso, esta vez con el cuento final "La princesa Rayo de Luz" (cap. XVI). Este cuento maravilloso, que tiene lugar en la corte de un poderoso rey, destruye la separación entre la norma culta - el habla de los reyes, reinas-y la norma popular —el habla del pueblo. Aquí el rey, que bebe mucho durante las ceremonias reales, ante las reconvenciones de la reina repite vulgarmente más de una vez, "Al diablo el ceremonial" y juzga al Hada Madrina una "bellaca" (188).

La ruptura entre los distintos niveles de la lengua se da también en los nombres de los personajes del cuento. El trovador, que resulta ser el Príncipe Rayo de Sol, opina que la princesa que se llama Diamela, tiene "un nombre muy vulgar, el mismo nombre de una perrita lanuda de su tía Petrona" (187). La ironía es doble no sólo por la incorporación de otro nombre vulgar, Petrona, sino porque Diamela, etimológicamente viene del latín vulgar (lat. dies: día). ${ }^{33}$ Evidentemente, los conocimientos lingüísticos de Holmberg le permiten no sólo delinear una conciencia idiomática, que está marcando los dos niveles de lengua, el culto y el popular, sino jugar con la etimología de los nombres, aspecto ya desarrollado en obras anteriores.

Toda la novela es un muestrario de nombres con doble etimología, así el nombre del protagonista principal, Olimpio Pitango de Monalia. Olimpio alude a la mitología griega, el monte Olimpo sede de los dioses; Pitango viene de pitanga, argentinismo que designa al arrayán, ${ }^{54}$ y Monalia, el nombre de la isla imaginaria, es el país de los monos - etimología dada por Holmberg - porque imitaron todo lo que las

52 Entre sus traducciones, Los documentos del Club Pickwick de Dickens en El Argentino 1874, El mundo perdido de Conan Doyle en Fray Mocho (Pagés Larraya, "Estudio preliminar", ob. cit. 50).

53 Joan Corominas, Diccionario crítico-etimológico castellano e hispanoamericano (Madrid, Gredos, 1980), s.v.

${ }^{54}$ Lisandro Segovia, Diccionario de argentinismos, neologismos y barbarismos (Bs. As., Coni, 1911), s.v. 
otras naciones hispanoamericanas habían hecho antes. Este nombre es otro hito importante que refuerza el sentido de toda la obra: la unidad en la diversidad cultural de Hispanoamérica. Hispanoamérica y especialmente la Argentina, el Uruguay y el Paraguay, las naciones con las cuales Monalia, por intermedio de Olimpio Pitango, quiere firmar un tratado de paz y cooperación, son un ejemplo vivo de esa diversidad cultural que une lenguas indígenas —el guaraní y el quichua- lenguas nacionales y populares - la gauchesca - con las diversas lenguas de las sucesivas corrientes inmigratorias, que empezaron a llegar a partir de la segunda mitad del siglo XIX.

Este otro estrato lingüístico, el de los dialectos y jergas de los inmigrantes, tambiẻn es registrado en el texto a través de los dos grupos inmigratorios más importantes de la Argentina: el de los andaluces y el de los italianos. Ambos discursos son transcriptos fonéticamente, el de los andaluces representado en el cuento del sevillano que no pudo llegar a Grecia, porque: "Cá; impozible; ar yegá al Estrecho del Gibrartá no’ zemo encontrao una bayena atravezá que no nos dejó pazá" (116). El dialecto de los italianos aparece en el genovés enriquecido en la Argentina por la fabricación de vinos falsos: "Ma, il vin si prepara de cuarque cosa, de cuarque cosa ... anque al úrtimo con l'uva" (156). Nueva ruptura de la separación entre la norma culta y la popular, al incorporar estos dos discursos, el del italiano y el del andaluz, pertenecientes al nivel popular de la lengua, que coexisten con el francés y el inglés, éstos dentro del nivel culto.

La Argentina es el producto de este mosaico de lenguas que detecta las distintas tensiones de las tendencias discursivas de la época, registradas tempranamente en la literatura en Olimpio Pitango de Monalia. Quizás éste sea uno de los tantos aciertos de la obra, el haber tenido conciencia de la heteroglosia de la Argentina, no sólo por su condición de nación mestiza, sino también por el carácter cosmopolita de su lengua nacional marcada por los distintos grupos inmigratorios que la poblaron.

Evidentemente Holmberg, que alcanzó a comprender “el conflicto de la lengua", como él mismo lo definió, 55 estaba en una posición de privilegio para reproducir en la novela la heteroglosia del discurso de su época, no sólo por su formación científica y el conocimiento de varias lenguas, sino por sus estudios de filología y de literatura universal.

55 Veáse p. 19 de este trabajo. 


\section{MULTIPLICIDAD DE GÉNEROS}

La polifonía y dialogismo alternan en la obra con una multiplicidad de géneros. Junto al canónico lírico, Holmberg utiliza los siguientes géneros discursivos: el histórico, el retórico y el literario.

1. Género histórico: aparece como género serio-cómico en las interpretaciones del pliego de papel encontrado por el paleógrafo Ñanga Pichanga.

El propósito es hacer una parodia de las interpretaciones paleográficas para evidenciar la falibilidad de las mismas.

Las interpretaciones paleográficas del obliterado documento acerca de una supuesta ruina histórica, dan lugar a las afirmaciones más disparatadas. Fue el "sabio" Ñanga Pichanga, el primero que reconstruye el documento "a los pocos minutos de haberlo recibido":

Es bastante fácil determinar desde la cumbre mirando hacia abajo $y$ casi justo hacia el NO las ruinas por donde hoy pasan dos sendas y se descubren a veces algo veladas por arena de la playa, cubierta de conchillas. Se ven bien alineadas desde las montañas (140).

El periódico El Regulador, da dos interpretaciones más:

Se ha podido determinar apoyándose sobre base tan segura $y$ aún ajustada hasta que punto se arruinará en salud y pensando siempre de un modo descabellado. Descuidadas las precauciones desmaya su ánimo y continúa en demencia al tenerlas por patrañas (141).

La segunda interpretación, esta vez en latín, es la "opinión de [otro] Pichanga":

Sub-hoc nomine determinare possumus crebrem punctatum orthorhynchum $j u$ dicatumm habitu sectiones gruinarum atque forsan adhuc non descriptum. Alterum ad kalendas Julius in montibus Himalaya repertum satis est conforme et fert apud hispanos nomen "alcarabán de las montañas" (143). ${ }^{56}$

56 Esta frase cuya traducción sería: "Con este nombre podemos designar al común (abundante) orthorhynchum (de pico o morro derecho) y plumaje 'densamente puntuado' [que se cree que se encuentra o vive en los lugares de las grúas], y que probablemente todavía no ha sido descrito. El otro o el segundo, encontrado el $1^{\circ}$ de julio en el Himalaya, es muy semejante y lleva en español el nombre de 'alcarabán de las montañas'”. La frase que está entre corchetes "judicatum habitu sectiones gruinarum", correspondería a un "latín de cocina" al que se alude luego en el texto. Traducción basada en la interpretación dada por el autor en la novela. 
Con esta interpretación en latín "de cocina”, que parece ser la "nota fugaz de algún naturalista" (143), se parodia además el uso del latín en los tratados de las ciencias naturales. La ironía se acentúa cuando el periódico aconseja que se busque en el Museo de Molenia, "entre las zancudas, y en la sección de las grullas (gruinae) la que tenga el plumaje "densamente puntuado"” (143), aquí se traduce grullas, por gruinae, en vez de gruis.

Finalmente "la interpretación del rompecabezas" se esclarece. El documento era "una tira de papel colocada como indicador en cierta foja" de un legajo, y "representaba el fragmento de un borrador de un informe médico-legal", cuyo texto íntegro, que estaba precisamente en la página indicada por la tira, era:

Es muy difícil determinar cómo un hombre tan rico $y$ tan juicioso haya podido caer en ruina. Los unos piensan que sus facultades se encontraban alteradas; los otros opinan que haya quizá confiado demasiado en alguna persona de malas mañas (144).

Aunque se menciona en el texto que cuando se anunció el descubrimiento de la hoja de papel se dio un "facsímil fotográfico" de la misma, esto no ocurre, con lo que se oscurece más el galimatías. Son las sílabas subrayadas en todas las versiones, las que dan la clave de las originales "afirmaciones obliteradas" aparecidas en la hoja de papel: determinar bre $n$ y ju ba ruina san des das aya con en al las añas.

El propósito en todas estas versiones ha sido mostrar los extremos en que puede caer la paleografía en su afán de interpretar los documentos del pasado. La ironía se acentúa cuando se acota:

La paleografía está llena de abrojos y bastará que recordemos cuántos comentarios arrancó a los arqueólogos, filólogos y lingüistas la interpretación de las palabras inscriptas en cierto vaso:

Itis Apis Potan Dabi Cone (141).

Sátira que termina con otra humorada, pues la última frase en latín, tal como está, carece de sentido.

2. Géneros retóricos. Los géneros retóricos satirizados son la arenga y las diatribas o polémicas periodísticas.

a) la arenga: la ironía a la historia como género serio emerge con la interpretación de documentos históricos falsos acerca de los supuestos héroes Cachimbo Pérez y Botijo. El primer documento, 
enviado por OP desde Buenos Aires, es una fotografía que está en "una hoja de papel de hilo, bastante quemada", salvada del incendio de "la famosa biblioteca del Colegio Nacional de Santiago del Estero, provocado por el canónigo" (146). Pero lo que importa, no es la descripción de la fotografía, sino la interpretación de la rúbrica de Cachimbo Pérez, "que será el único documento positivo revelador del modus operandi de Cachimbo al modelar sus arengas" (147). Esta rúbrica que aparece dibujada en el texto, es interpretada según las características del discurso de la arenga, ya que reproduce el "exordio", los "argumentos" y "silogismos" de la arenga (147).

Fue precisamente el artículo incendiario de Olimpio Pitango, la arenga destinada a despertar en los monalitas el entusiasmo y el valor para que abandonen las viejas prácticas gubernamentales, $y$ se organicen constitucionalmente: “¡Despierta, Monalia, de tu sueño secular! haz honor a tu nombre, levántate altiva, reivindicando tus derechos en el pasado, en el presente y en el porvenir" (85). El artículo que reproduce la oratoria de sentido patriótico de las arengas dio su fruto, pues esta "elocuencia de barricada" (86) convulsionó a todo el pueblo y desencadenó un fervor político desconocido hasta entonces. El artículo produjo además "el renacimiento de las antiguas, olvidadas prácticas oratorias" (88), como lo prueban luego los discursos del diputado Toribio Albarda sobre el papel de la mujer en el nuevo régimen político (123), y sobre las diferencias entre la oratoria de los anglosajones y los latinos (146).

b) la polémica es el otro género retórico satirizado a través de las diatribas cruzadas entre los dos diarios políticos, El Patriota y El Regulador. La controversia política entre estos dos diarios empieza en el capítulo IV y ocupa gran parte de la novela. Mientras El Patriota apoya a OP y al partido político del mismo nombre, El Regulador desprestigia todo evento que procede de dicho partido y que se relacione con OP.

3. Género literario: el cuento maravilloso o de hadas está representado en "La princesa Rayo de Luz", último capítulo. El esquema estructural de este cuento maravilloso corresponde a lo que Propp 57 ha definido como el deseo de poseer algo, en este caso la mano de la hermosa princesa Rayo de Luz, hija de un poderoso Rey. A la corte del Rey llegan príncipes de otros poderosos reinos, pero la princesa Rayo de Luz se enamora de un simple trovador.

57 Vladimir Propp, Las raíces históricas del cuento (Madrid, Editorial Fundamentos, 1987), pp. 17 y ss. 
Esta complicación, que enoja al Rey, recibe una probable solución de la Reina quien aconseja al Rey que convierta al trovador en miembro real, mediante la adjudicación de un título noble. Finalmente todo se resuelve cuando el trovador declara que él es el Príncipe Rayo de Sol, origen noble que había ocultado hasta entonces.

4. Género lírico: Holmberg utiliza este género en varias oportunidades. La mayoría son composiciones populares. Así los pensamientos autógrafos que OP escribe para sus admiradoras argentinas: uno es un cuarteto de arte mayor en rima aconsonantada (107), el otro es una décima clásica de versos octosílabos (107). El tercer poema popular aparece en el cuento final, y es una octava con rima aconsonantada (189). Por último, el himno nacional que OP compone titulado "El triunfo póstumo" está escrito en heptasílabos asonantados alejandrinos, con "la cesura del hemistiquio clásico" (99). La ironía aumenta cuando se sugiere que este himno permite ser cantado con la música de "Cuando Juana de Arco tocaba la corneta", con "Arrorró mi niño, Arrorró mi amor" o con "E viva Garibaldi" (100).

La mezcla de géneros literarios con géneros extraliterarios -el histórico y el discursivo- rompe la clásica separación de los mismos, al mismo tiempo que desautoriza la preeminencia de alguno: multiplicidad de géneros canónicos con populares que persigue una carnavalización literaria. Por otro lado, se observa una intención arcaizante de volver a antiguos géneros del pasado como la arenga, el cuento maravilloso, el verso alejandrino, intención que tiene eco en la caracterización de OP. En una nota dentro del texto, Holmberg describe a OP como a un personaje "épico" que "conoce a Esquilo y a Prometeo" (238). Esta vuelta a la antigüedad encaja perfectamente con la admiración que Holmberg sentía por las literaturas griega y clásica, en las que importaba más el pensamiento que la forma.

\section{MULTIPLICIDAD IDEOLÓGICA}

La asombrosa libertad temática de la novela, que incursiona en una multiplicidad de temas, refleja a Holmberg en toda su complejidad: conjunción del intelectual con el científico que aborda los más variados asuntos. Aunque muchos de estos temas se pueden rastrear en sus ensayos intelectuales y científicos, lo nuevo aquí es que Olimpio Pitango de Monalia es la primera obra de ficción de Holmberg, que resume y contiene este polimorfismo ideológico. 
La ideología presente permite la siguiente clasificación: 1 . ciencias naturales, 2 . filología, 3 . cultura griega, 4 . pedagogía, 5 . feminismo, 6. genialidad/irracionalidad, 7. reflexión histórica.

1. Ciencias naturales. Entran en este apartado sus caras ideas acerca del transformismo y evolucionismo. Ideología que a manera de columna vertebral va sosteniendo el andamiaje de la obra.

Gran parte de esta ideología científica de Holmberg ya había aparecido en sus trabajos sobre el darwinismo que él popularizó en la Argentina. Precisamente el plan de Olimpio Pitango es la transformación de Monalia arcaica en moderna y progresista, para poder hacer frente a los deseos expansionistas de las grandes potencias.

En Monalia, país agropecuario esencialmente, se deben multiplicar los astilleros, las usinas, y construir acorazados, torpederos y submarinos, "instrumentos con que los pueblos defienden su existencia o luchan por la vida" (145). La lucha por la vida, axioma darwinista, 58 "es una ley fundamental de la vida" (83). OP ha intuido que, "por encima de todas las diplomacias" de todas "las fraternidades", se "levanta la ley natural del hombre, de la lucha por la vida y del triunfo de los más aptos, cualesquiera que sean los instrumentos que esa lucha pueda poner en juego" (169).

Lamentablemente "el espíritu de guerra" no se extinguirá “jamás en la Humanidad, género de mamíferos provisto de colmillos” (177). 59

A sus conocimientos de las ciencias naturales corresponde la lista de geólogos y botánicos (158-159); la mención del Cardo de Castilla (138) - especie descubierta en la Argentina por Holm-

58 Según explica Holmberg, Darwin aplica en la lucha por la vida la Ley de Malthus [On Population]: "El hombre se propaga en progresión geométrica y los alimentos en progresión aritmética" (Carlos Roberto Darwin, 62-63). Más adelante agrega: "los blancos, los civilizados, los cristianos, armados de remington, acabamos con los Indios, porque la Ley de Malthus está arriba de [...] opiniones individuales, $[. .$.$] sea porque falte aún mucho para que la humanidad esté civilizada, sea$ por cualquier otra causa, no se hacen carne - y así luchando también nosotros por la vida, con buenas ideas, con buenas armas, con buenos recursos, no hacemos más que poner en juego nuestras ventajas" (Carlos Roberto Darwin, 66).

59 En otra oportunidad Holmberg expresa que "La paz universal es una quimera" porque "el Hombre tiene la pugnacidad natural de su estirpe de colmillo" ("De Siglo a Siglo", Anales de la Sociedad Científica Argentina [julio de 1901] 52, 53). Estas ideas encajan con lo ya puntualizado más arriba, en el apartado sobre Sarmiento y Holmberg, de que la doctrina de Darwin podría llevar al hombre a la perfección sino fuera "indefinida por el progreso", y por los antecedentes simios del hombre (Carlos Roberto Darwin, 67). 
berg-;60 la nómina de las aves insectívoras que son exterminadas por los cazadores (155); la descripción geográfica de la isla de Monalia -constitución geológica, hidrografía, clima, flora, fauna- con su correspondiente mapa físico (75-76).

2. Filología. A este tema corresponden las dos conferencias sobre el lenguaje dadas en Monalia. En la primera, un conferenciante monalita menciona "la teoría del lenguaje hablado antes de manifestarse en las tres formas consagradas por los filólogos" (78); alude a las tres teorías del lenguaje - la naturalista, la síquica y la de los neogramáticos- originadas por el desarrollo de las ciencias naturales, y la presencia de Darwin en el siglo XIX.61

En la segunda conferencia se hace referencia al sánscrito, a los dos grandes poemas épicos hindúes, el Mahabharata y el Ramayana, y a las lenguas religiosas seculares, el pracrito y palí (80), lenguas que derivan como el sánscrito del tronco ario.

3. Cultura griega. Como lo testimonian las notas explicativas del texto, la cultura griega es otro elemento vertebrador en la obra. Las referencias abarcan las letras (Aristófanes, Homero, Esquilo, Safo, Xenofonte, Herodoto), la filosofía (Sócrates, Platón, Aristóteles), las ciencias (Arquímides), la escultura (Fidias, Praxíteles), la historia (Alejandro Magno, Alcibíades, Demóstenes, Licurgo, Solón, Pericles, Aspasia, Arístides), los deportes (Milón de Crotona), la mitología (Zeus, Apolo, Atenea, Aquiles, Teseo, Ariadna, Fedra, Pentesilea, Penélope) y la educación tanto espartana como ateniense (77), más de una vez modelo a seguir por los monalitas.

4. Pedagogía. Los muchos años de docencia de Holmberg y sus lecturas le permitieron elaborar un cuerpo de doctrinas que en la novela se materializan en la descripción de ese "paraíso terrenal" que es Monalia, y en la educación de sus niños.

La instrucción pública ha sido "la mayor preocupación" de Monalia durante los tres siglos de existencia (180). Aquí reside su "grandeza real", en esa constante inquietud "de desenvolver, desde la más tierna infancia, las aptitudes individuales de los niños”

${ }^{60}$ En Carlos Roberto Darwin, Holmberg informa que fue él quien descubrió la existencia del Cardo de Castilla (Cynara Cardunculus). La presencia de este cardo en el campo argentino ejemplifica "The struggle for life" de Darwin. Holmberg llamó la atención al gobierno argentino sobre la rápida propagación de este cardo nocivo para el ganado, que amenazaba desterrar las especies de cardos que comían los animales (58-63).

61 Véase nota explicativa 6 en el texto de OPM. 
(181). Es misión de la madre el descubrir y cultivar dichas facultades mediante lecturas apropiadas (157).

La madre de Olimpio Pitango es quien "realiza un ideal pedagógico" en la ciudad, al desarrollar en el niño, mediante el relato de cuentos, "la facultad más necesaria para el hombre intelectual", la imaginación (181). La imaginación es la fuente de toda actividad creadora, no sólo para los poetas, escultores y pintores, sino para los matemáticos, físicos, químicos y naturalistas (181). Mediante los cuentos que intercalan "con prudencia lo maravilloso" se les obliga a los niños "a pensar sin que lo sientan" (181-182).

Con respecto a las entidades metafísicas, la verdad y la justicia, que serán tema de reflexión de Holmberg a lo largo de toda su obra, 62 el procedimiento impartido en las escuela era análogo: "No les definían la Verdad diciendo que es lo que es, sino que les presentaban los hechos, las cosas, demostrándoles que tal cosa, una piedra, por ejemplo, era una piedra; que tal otra era una mosca; que la mosca no era una piedra y ésta no era una mosca" (102). Este sistema bautizado por la pedagogía moderna con el nombre de "método intuitivo, no tenía nombre en Monalia; no tenía sino existencia” (102). Solamente cuando estaban más maduros racionalmente, se les definía así la verdad: "es una condición esencial de la existencia de las cosas y de sus relaciones" (102).

Debido a la importante misión del maestro en la formación de los niños, en Monalia:

62 Tema que se rastrea en otras obras: "Disculpadme, los que me lo hayáis oído en otras ocasiones y en lejanos pueblos, si repito las palabras del gran filósofo chino Lao-Tsé, precursor de Confucio, y anterior por más de 5 siglos a la Era Cristiana o Vulgar: La tarea más noble del entendimiento humano consiste en la investigación de la Verdad, y como la Verdad no puede conquistarse sino sobre la base de la evidencia, es menester comenzar por despojarnos de todas las causas susceptibles de oscurecerla, ocupando entre ellas, en primer lugar, los sentimientos, base de todos los perjuicios, de todas las preocupaciones, de todos los fanatismos" ("Las Ciencias y la Masonería", conferencia inédita manuscrita, p. 2, en mi archivo); "Cuando en vez de respeto, que es un sentimiento, hay intolerancia que es otro, no puede resultar de su encuentro la verdad, porque la verdad es simple, y las cosas simples se buscan directamente y se encuentran ó no se encuentran" (Carlos Roberto Darwin, 110); "y en tono burlesco, escribí, poniéndolo en boca de un profesor de filosofía: 'la Verdad es lo que es, pero lo que no es también es verdad'. Ninguna frase me ha preocupado más desde entonces. Tartarín de Tarascón no habría quedado más sorprendido con una mentira forjada por él" (Viaje a Misiones, 10). Aunque el tono irónico es obvio, como en gran parte de la obra de Holmberg, está aquí aludiendo a que el lenguaje no define la esencia de algo (verdadero), sino solamente está representando ese algo. 
No enseñaba el que quería sino el que podía.

Y para poder enseñar era necesario ser apto (102).

La aptitud, "base de la estructura física, intelectual, moral y social de Monalia” (149), se desarrollaba desde la más temprana edad en el hogar (157). En Monalia, "[h]abituados desde sus orígenes a la selección de las aptitudes" (103), para cualquier actividad era necesario ser apto, y "habrían declarado loco, mal patriota y caduco al gobierno que hubiese recomendado para dirigir las actividades militares a un monalita entendido en la fabricación de vidrio solamente o a otro reconocido apto en la confección de versos líricos" (103). Es probable que este énfasis en la aptitud le venga a Holmberg de su conocimiento de la filosofía de Lao-Tsé y Confucio; fue éste quien proponía el cultivo de la aptitud por medio de la educación, y que sólo debía gobernar aquél que tuviera aptitud para ello. 63

5. Feminismo. El capítulo IX, titulado "Feminismo", reproduce el discurso del diputado Toribio Albarda acerca del papel que debe tener la mujer en el nuevo régimen constitucional. A través de ejemplos de mujeres famosas de la historia y de la mitología -Catalina de Rusia, Isabel de Inglaterra, María Teresa de Austria, Isabel de Castilla, Safo, Belona, Palas Atenea y otras más- demuestra que la mujer siempre se ha destacado en cualquier actividad, ya sea política, artística o social. Aunque el discurso de Toribio Albarda propone "la intervención de la mujer en todas las tareas que corresponden a la evolución política y social de Monalia" (130), en este despliegue de funciones viriles desempeñadas por mujeres, las "reticencias escondidas en la sucesión de los ejemplos” (130) infunden sospechas.

Precisamente en el capítulo XIII, "Las mujeres de Monalia a los miembros de la Convención Constituyente", exponen que detrás de cada hombre ilustre - Humboldt, Cuvier- ha habido una madre cuyo talento le permitió descubrir y desarrollar las aptitudes del hijo. Aquí reside la superioridad de la mujer, "en la educación de la niñez y de la juventud" (161). Por lo tanto piden que los derechos electorales para la mujer, requeridos por el diputado Albarda, "no sean acompañados de la imposición militar del voto obligatorio" (161).

63 Véase nota explicativa 123 sobre Confucio en el texto de la novela. 
En consecuencia, el feminismo en Holmberg va más allá de los ejemplos de mujeres excepcionales que la Historia ofrece: la mujer tiene una misión importantísima en la nación. Holmberg continúa aquí la orientación ya iniciada en la Argentina por Alberdi y Sarmiento, ${ }^{64}$ acerca de la necesidad de que la mujer se eduque, porque de ella depende la formación de los futuros ciudadanos, la industria y la moralidad de un país.

Así lo entendió él desde muy joven, cuando se inició como profesor en la Escuela Normal de Profesoras, e introdujo el estudio de las ciencias naturales, la teoría de la evolución, los nombres de Laplace, Darwin, para desafiar a esa gente que se empeña "en que las mujeres sean solemnes ignorantes", cuya única obligación "consiste en mantener su cerebro en un estado de vacuidad seráfica” ("Discurso del Dr. Eduardo L. Holmberg", Homenaje, 732). Producto de esta educación científica fue la Doctora Grierson, la primera médica argentina que fue su alumna en la Escuela Normal de Profesoras. 65

Otro discurso de Holmberg, esta vez pronunciado cuando se trasladaron los restos de la Sra. Emma N. de Caprile, directora de la Escuela Normal de Profesoras, ilumina la posición de Holmberg con respecto a la educación de la mujer. Aquí expresa que "[n]uestro grande error político no es la forma republicana de gobierno -es el descuido en la educación de la mujer". Las mujeres están destinadas a ser las maestras de primeras letras, tienen "ese secreto, los hombres no". Para ello no necesitan "mucha química, mucha filosofía", sino que lo que ellas necesitan es necesario para "el país entero que debe pulirse en la escuela y por la escuela". Es aquí donde la mujer suaviza los instintos, que a veces "derrumban las aspiraciones de pueblo culto", y esto no se puede lograr si las mujeres no son "instruidas, muy instruidas".66

64 Véase mi estudio sobre este tema en Origenes del costumbrismo ético-social (ob. cit., pp. 122, 144).

65 En ocasión del Homenaje a Holmberg en 1915, cuando se retiró de la enseñanza, la doctora Grierson expresó en su discurso: "Nosotros que aprendimos el catecismo de Astete y que nuestra frágil memoria nos hizo olvidar hace rato, hemos, en cambio, tratado de poner en práctica lo que con su ejemplo y palabra nos enseñó él [Holmberg]" ("Discurso de la Doctora Grierson" en Homenaje al Dr. Eduardo L. Holmberg, ob. cit., 723). Es interesante la mención del catecismo de Astete (ver nota explicativa 131 en el texto de $O P M$ ), del cual se hace una sátira como se verá más adelante en la novela.

66 "Discurso del Dr. Holmberg en la inauguración del monumento a la memoria de la Señora de Caprile" (El Nacional, agosto 10, 1887, col. 3). 
Algunos conceptos pronunciados en esta ocasión son similares a los que aparecen en OPM, como así lo evidencia el siguiente cotejo:

La madre de los Humboldt, la madre de los Cuvier, son los primeros profesores de ciencias que tienen esas grandes figuras de nuestro siglo ("Discurso", 2a. col., s.p.).

Dos grandes hombres, representantes genuinos de estas dos últimas naciones [Francia y Alemania], debieron su grandeza a la dirección materna y a su talento: Jorge Cuvier y Alejandro Humboldt, y con ellos podríamos citar plêyades de varones ilustres cuya celebridad tuvo igual origen (Olimpio Pitango de Monalia, 160).

6. La irracionalidad y la genialidad. La genialidad y el talento, enmascarados en actitudes aparentemente irracionales, aparecen más de una vez en la obra de Holmberg. ${ }^{67}$ En OPM esta fusión que sirve para caracterizar a un hombre público, Olimpio Pitango de Monalia, retrotrae a los comentarios vertidos en Sarmiento, ya puntualizados.

Cuando Europa se entera del plan de Olimpio Pitango, lo declaran "loco o fraguando una gran mistificación" (96); su obra, opinan, "parece una pesadilla, verdadera creación de un lunático, y en ciertas ocasiones de un loco de remate" (97). Para Francia, OP semeja Don Quijote "cuando le zumbaban al oído ráfagas de caballería" (98); y el gobierno de Monalia, ante el tumulto que su ardiente arenga ha originado, lo juzga "loco de remate" y dispone alejarlo del medio con una misión diplomática (106). Es sólo al final, después de sus actividades diplomáticas, que el gobierno comprende que, "Olimpio no está loco ni lo ha estado nunca" (132); conocedor de Prometeo —el defensor de la humanidad- es el "profeta", el "vidente" (133), que advirtió que la seguridad nacional estaba en peligro.

Seguramente Holmberg conocía la abundante bibliografía sobre la locura que proliferaba en la Argentina, ${ }^{68}$ pero quizás la fuen-

${ }^{67}$ En Viaje maravilloso del Sr. Nic-Nac, el "loco del matraz"; en "El tipo más original", el extraño profesor Burbullus, políglota, que cada día de la semana habla una lengua diferente.

${ }^{8}$ Pagés Larraya cita las siguientes obras y autores populares durante la época de Holmberg: Las neurosis de los hombres célebres de Ramos Mejía; La locura en Buenos Aires de Samuel Gache; Los manicomios de Norberto Maglioni (ob. cit., pp. 37-38). Holmberg menciona Las neurosis de los hombres célebres de Ramos Mejia en Carlos Roberto Darwin (117). 
te de este tema en él haya que buscarla en el romanticismo alemán, particularmente en Hoffmann, autor que Holmberg cita constantemente, ${ }^{69}$ especialmente su relato "Councillor Krespel". 70 Olimpio Pitango es otro Krespel, según las palabras de Claudio Moloso, que "Para realizar [su] gran concepto [ha] gesticulado como un violinista" (163), símbolo que se intensifica cuando más adelante agrega Moloso que "la seguridad de la Patria exigía que continuara Krespel gesticulando en su violín de Cremona" (164).

No por nada este personaje Krespel es recordado por Holmberg cuando escribe sobre Sarmiento, para justificar la expresión de "morisquetas" irracionales para la mayoría, ${ }^{71}$ pero que resultan un acto de catarsis interior:

"En el fondo del alma de todo hombre, por serio y grave que sea" —contesta Krespel- "hay una morisqueta escondida. Si no se suelta al aire, como yo lo hago, se convierte, por extrañas metamorfosis, en semillero de maldades. Ella es origen de calumnias, maledicencias e injurias, todo lo cual no se aviene con mi carácter" (Sarmiento, 50).

Es por esto que el "loco Sarmiento" - como lo llamaban despectivamente- y Olimpio Pitango serían ejemplos de seres en los que la genialidad produce morisquetas aparentemente irracionales.

La clave de la personalidad de Sarmiento, tal cual la delinea Holmberg en su estudio Sarmiento, permite extraer las siguientes

69 Además de titularse uno de sus cuentos "La pipa de Hoffmann", Holmberg comparte con Hoffmann la sátira a la sociedad de su tiempo —que esconde un horror frente a un mundo en transición- la imaginación creadora y la creación de caracteres extraños, excéntricos, locos o autómatas (particularidades presentes en "The Sandman", "The Doubles" de Hoffmann, y en "Horacio Kalibang o Los Autómatas" de Holmberg).

${ }^{70} \mathrm{El}$ consejero Krespel es un personaje tildado de loco por la población por sus excéntricas actitudes; es el Profesor M. quien explica su comportamiento: "There are men [...] from whom nature or some peculiar destiny has removed the cover beneath which we hide our own madness. They are like thin-skinned insects whose visible play of muscles seem to make them deformed, though in fact, everything soon returns to its normal shape again [...] Krespel expresses bitter scorn in mad gestures and irrational leaps, even as does the spirit which is embedded in all earthly activity". ("Councillor Krespel”, Selected Writings of E.T.A. Hoffmann. vol. I. Ed. y trad. Leonard J. Kent y Elizabeth C. Knight [Chicago-London: The University of Chicago Press, 1969], 180).

71 " $[\mathrm{L}]$ os que hemos tenido oportunidad de examinar sus manuscritos de periodista [las contribuciones de Sarmiento a la prensa argentina y chilena] hemos podido encontrar más de un tic simbolizado por un rasgo intempestivo de pluma $o$ por una interjección demasiado profana" (Sarmiento, 34-35). 
semejanzas con OP: ambos son grandes oradores y diplomáticos, hombres públicos en conflicto con su medio, que asumen la labor de organizar constitucionalmente sus países. Sarmiento en 1800 , Olimpio Pitango en 1900 tienen sentido porque:

En las diversas tonalidades de la cultura humana, cada una de ellas tendrá con el tiempo, entre nosotros los Argentinos, un Sarmiento propio (Sarmiento, 47).

Parafraseando a Renan, Holmberg agrega que "muchas veces se confunde el loco con el hombre inspirado; pero el loco no deja en pos de sí nada estable. El extravío de la razón no ha tenido hasta ahora ninguna influencia en la marcha del género humano" (Sarmiento, 41). Esta confusión entre el loco y el hombre inspirado resulta por no haberse advertido que la "individualidad humana sólo proyecta una imagen virtual" de la vida (Sarmiento, 15).

Lo que está representando Holmberg, tanto en su descripción de Sarmiento, como en la caracterización de OP, es —como él mismo lo expresa- la fusión de genio y talento al "servicio de doctrinas políticas o sociales" (Sarmiento, 39), que despiertan "en [el] espíritu todas las incongruencias de un loco y todas las fulguraciones de un genio" (Sarmiento, 42). Así, cuando Olimpio Pitango regresa a Monalia, después de su misión diplomática, le explica al gobierno que su reforma política y social, consecuencia de "una larga premeditación", le significó en un primer momento un dilema:

Aquel dilema se formulaba de este modo: $\mathrm{O}$ expongo en forma seria y grave los fundamentos de la reforma necesaria ... o bien expongo esos fundamentos en una forma fantástica y descabellada para una minoría seria y grave que me considerará loco de remate y me dejará en paz, pero imponente y necesaria para una mayoría abrumadora, y en tal caso hay probabilidades de triunfo y entonces mi obra puede ser fecunda (OPM, 164).

Implícito está aquí el concepto de que las masas reaccionan más fácilmente ante actitudes irracionales, porque no piensan - tema ya desarrollado en la Argentina por Alberdi- ${ }^{72}$ Holmberg expresa también en Sarmiento:

72 El concepto del pueblo-masa, sin criterio propio, ya aparece en el periódico La Moda (1837) de Alberdi. Analizado en mi libro Origenes del costumbrismo ético-social (121). 
$\mathrm{Y}$ cuando el genio y el talento se funden por extraño consorcio, tal cual sucede en Sarmiento, y esa fusión se pone al servicio de doctrinas políticas o sociales, el mundo interno que encierra aquel caudal es como la espada flamígera del arcángel, que podrá deslumbrar á las turbas, pero no á los que flotan en la región de los iguales superiores (Sarmiento, 39).

Quizás Holmberg esté dando la clave de su quehacer cuando confiesa que después de haber leído las obras de Sarmiento (especialmente Facundo y sus artículos periodísticos), y de haber escuchado algunas de sus conferencias, advierte que la caracterización de Sarmiento podría figurar "en alguna parte como personaje de novela" $y$, "es evidente que habría podido constituir una personalidad más subjetiva que desenvuelta en la circunstancialidad de la trama" (Sarmiento, 24).

7. Reflexión histórica. Este aspecto, que lo acerca a Sarmiento en más de una ocasión, especialmente en sus ideas acerca de la herencia española y en el análisis de los cánceres de las naciones sudamericanas, encaja perfectamente con la figura del intelectual que reflexiona más de una vez acerca de su país e Hispanoamérica.

Es el discurso testimonial de Olimpio Pitango, ministro plenipotenciario en Sud América, el que va descubriendo una realidad caótica. Aunque Monalia, Uruguay y la Argentina tienen el mismo origen e idioma, la misma sangre, las mismas necesidades, Monalia difiere de ellas porque "henchida de civilización [...] no surge de la barbarie colonial, de la ignorancia, del fanatismo, del atraso en que aquellas dormían" (165). Agudamente realiza la radiografía de los "cánceres" sudamericanos que impidieron el ejercicio de la democracia:

[L]as naciones hispanoamericanas eran víctimas [...] del espíritu añejo de su origen, con leyes civiles y militares hediondas de Inquisición y de Siete Partidas, tufo de horcas y de conventos, infulas de republicanos que hablaban de libertad y democracia mientras hacian punterías a blasones apócrifos [...] señores feudales civilizados y bruñidos en los grandes centros, y asesinos inmundos de cepo y de látigo en los tugurios solariegos adquiridos por la usurpación a los débiles; corazones corrompidos por el ejercicio de una autoridad secular ejercida sobre almas primitivas a las que no habían dado en tanto tiempo otra luz que la de los candiles conservándolas bajo la influencia de un terror perpetuo con el nombre de religión (170).

Es importante rastrear las concomitancias de esta ideología con los artículos periodísticos de Sarmiento, para quien el origen co- 
mún de los países sudamericanos es también la causa de todos los males:

Hijos de unos mismos padres, mal educados, con hábitos viciosos que engendró la política de un siglo oscuro, y con las mismas dificultades en la transición, no es extraño que en todas partes suceda lo mismo y que aquí y acullá un observador halle los mismos defectos, encontrando las causas en origen idéntico ("La comedia de la libertad", El Mercurio nov. 14, 1841, Obras completas, vol. IX, Instituciones Sudamericanas [Bs. As., Imprenta y Litografía Mariano Moreno, 1896], 43).

Estos antecedentes, para Olimpio Pitango, explican el desarrollo político de la Argentina. "[D]espués de un régimen colonial absurdo y tiránico" (Olimpio Pitango, 104), no pudo educar a las masas por el surgimiento de la anarquía militar, que trajo como corolario la dictadura de Rosas. Como no se había enseñado lo que era la fraternidad y la igualdad, el concepto vago de patria "olía a terruño y la independencia había pasado a ser una época histórica y nada más" (Olimpio Pitango, 172).

En El Nacional Sarmiento ya había señalado la falta de preparación de los pueblos americanos para vivir procesos democráticos:

$\mathrm{Al}$ ver la serie de sucesos desgraciados, las tentativas malogradas y la falta de pericia de los pueblos americanos para organizarse de un modo permanente y estable, han creído muchos que la Revolución se inició a deshora y cuando los pueblos no estaban preparados para la libertad como si alguna vez el despotismo colonial, y el despotismo español sobre todo, fuese parte á preparar otra cosa que retroceso y envilecimiento ("Política americana”, El Nacional, abril 14, 1841, Obras, vol. IX, 1617).

En el desarrollo político de un siglo, señala Olimpio Pitango, la Argentina había experimentado todas "las locuras de los ensayos de la democracia" (Olimpio Pitango, 133):73 la Constitución, que

${ }^{73}$ Hay una especie de collage en el manuscrito formado con recortes de periódicos, que confirman la reflexión en el texto sobre la incompetencia de las naciones sudamericanas para vivir procesos democráticos. En el reverso de la p. 11 del cap. II del manuscrito, Holmberg ha pegado dos recortes de periódicos. El primero lleva como título: “1811. Revolución del Paraguay”, donde se informa que el movimiento emancipador del Paraguay fue iniciado por la presencia de Belgrano, que inspiró el sentimiento de libertad. La revolución libertadora fue el 14 de mayo de 1811 y el 15 de mayo, la declaración de la Independencia. Este recorte pertenece a la sección de "Efemérides" del periódico La Razón (14 de mayo de 1912, p. 13). El segundo recorte titulado, "Recibimiento del ejército. 
no se había reformado en medio siglo aunque se violaba con frecuencia en la práctica, la libertad de cultos, aunque "la religión de estado que permit[ía] a los gobernantes levantar una iglesia [católica] donde ...[faltaba] una escuela" (Olimpio Pitango, 172), la reciente ley sobre el sufragio secreto y obligatorio de Sáenz Peña, ${ }^{74}$ originada ante la anarquía política que había perpetuado el fraude electoral (Olimpio Pitango, 105).

Este fracaso del sistema institucional puesto en funcionamiento por los liberales, Sarmiento lo entendió perfectamente:

queríamos hacer avanzar a la América en el camino del progreso i de la civilización europea. Por desgracia ha sucedido lo contrario ("Al Señor H. Southern, encargado de negocios de S.M.B. Cerca del gobierno de Bs. As.”, Crónica, enero 20,1850, Obras, vol. VI, Política argentina [París, Berlin Hnos., 1909], 288).

\section{Y también:}

Las instituciones liberales sucumben en América, como plantas exóticas arrojadas en suelo ingrato y estéril... Es sin duda desconsolador el cuadro que el mundo civilizado presenta hoi. Vese la humanidad echada en una vía fatal, empujada hacia adelante por antecedentes que no la dejan pararse un momento" ("De la Revolución Arjentina", El Progreso, enero 11, 1843, Obras, vol. vi, 93).

En Olimpio Pitango, las deficiencias de este sistema se complementan con el análisis de la realidad socio-económica argentina de

Asunción mayo 14", alude a que el recibimiento del ejército vencedor de la actual Revolución en 1912, que depuso al presidente, el coronel Jara, coincide con el aniversario del movimiento emancipador. En este recorte Holmberg ha escrito al costado: “La Razón. Martes mayo 14 de 1912". Efectivamente este recorte se publicó también en el mismo periódico en la página 9, y es un fragmento de un artículo más extenso, titulado "Sucesos Paraguayos. La última jornada de la revolución. El ejército vencedor de Asunción" que comenta los últimos acontecimientos de la Revolución. Ambos recortes testimonian cómo una nación sudamericana, Paraguay, al cabo de un siglo, 1811-1912, todavía sigue viviendo procesos revolucionarios de inestabilidad institucional.

74 Alude a la ley de Roque Sáenz Peña sobre el voto secreto y obligatorio, aprobada en 1912 durante su presidencia (1910-1914). Por primera vez en la historia argentina, en 1916 se elige libremente, según esta ley, al presidente Hipólito Yrigoyen del Partido Radical. Los radicales se habían abstenido en el pasado de votar debido a que las elecciones estaban controladas por la aristocracia terrateniente (George Pendle, Argentina [Londres, Oxford University Press, 1963], 67-69). 
principios del siglo (1912-1913). ${ }^{75}$ Los males que sufre la Argentina actual, la ausencia de los valores éticos de la sociedad, la excesiva burocracia y la crisis económica, ya fueron pulsados en el discurso "sociológico" (152) de Olimpio Pitango.

A Olimpio Pitango le causa malestar "cierta superficialidad" en el carácter de los porteños que toman a risa cuestiones graves. En los negocios hablan de una diferencia de " 2 o 3 millones ... como si se tratara de centavos" (152), pero como "se gana el dinero con tanta facilidad" hay muchos potentados que hace unos años "carecían de zapatos" (152). Asombra la cantidad de intelectuales y "el arte soberano de algunos brutos para codearse con desenvoltura entre esos intelectuales" (151). Con respecto a la aptitud, "base de la estructura física, intelectual, moral y social de Monalia" se desconoce en la Argentina, "que cuando necesitan un diplomático nombr[an] un bailarín" (143)76 así "hay lugar para todos sin distinción de raza ni de aptitud" (143).

El gobierno que acaba de gastar 200 millones en la celebración del centenario de la Independencia argentina (1910), no habla de crisis económica, sino del abaratamiento de la vida. Si la carne vacuna sufre un impuesto de $1 \%$ en el costo, el precio de venta de la misma sube un $50 \%$, este "robo" al consumidor es justificado como inflación (153). ${ }^{77}$ La carencia de frutas y de verduras se debe

75 Mucho más tarde, José Luis Romero reflexionará sobre lo mismo: "The institutional system established and put into effect by the liberals little by little ceased to be adequate, being more advanced than actual conditions in some ways but deficient in many others (José Luis Romero, A History of Argentine Political Thought, trad. Thomas F. McGann [Stanford, California, Standford University Press, 1963], p. 165; versión original: Las ideas politicas en Argentina, Bs. As., Fondo de Cultura Económica, 1956.

76 Una observación similar aparece en Beaumarchais: "il fallait un calculateur, ce fut un danseur qui l'obtint". Le Mariage de Figaro en Studies on Voltaire and the Eighteenth Century, vol. LXIII , T. Besterman Ed. (Genève: Institut et Musée Voltaire, Les Délicies, 1968), p. 437; “Et si je deviens ministre, qu'est-ce qu'on dira? -Que vous êtes le plus beau danseur de tous les conseils du roi" (Notes et réflexions [Paris, Hachette, 1961], p. 76).

$77 \mathrm{La}$ obra testimonia un aspecto de la vida social que aparece escasamente documentada en las obras específicas. José Panettieri en Argentina: historia de un país periférico. 1860-1914 (Bs. As., Centro Editor de América Latina, 1986), alude a las deficiencias de información sobre este aspecto durante los años 1899-1903, pero confirma que efectivamente hubo carestía en Buenos Aires y da algunos guarismos: "En cuanto al aumento de los artículos de consumo [...] pueden efectuarse, aproximadamente algunas comparaciones. La carne de vaca [...] cuyo precio en 1904 era, según calidad, de 0,18 a 0,40 peso el kilogramo, costaba, en igual relación, 0,25 a 0,80 en 1911 [...] Las papas, que costaban 0,05 a 0,10 pesos, habían elevado su precio a $0,20 "$ (192). 
a que "los acaparadores la[s] compran por mayor" para surtir los hoteles o exportarlas, y cuando finalmente el consumidor puede adquirir algo de lo que haya quedado, lo paga con un aumento del $900 \%$ por "el número de intermediarios que separa al consumidor del productor" (154). Los abusos de la libertad de comercio llevan a la especulación y la deshonestidad, así el caso de un genovés enriquecido con la fabricación de vino falso (156). ${ }^{78}$

El escalpelo de la crítica minuciosa ausculta todas las deficiencias de la realidad social argentina: la carestía de la carne por la matanza indiscriminada de vacunos, la falta de caminos en el campo, la insólita presencia de campos de pastoreos para criar vacas lecheras en los alrededores de la ciudad, la ausencia de las yerbas aromáticas europeas en las comidas argentinas, la proliferación de las plagas de insectos debida a la caza de las aves insectívoras (155).

Otro cáncer detectado en la sociedad argentina es la burocracia, oficinas estatales llenas de empleados con "aires de perros rabiosos", cuyos asuntos más importantes son los concernientes al té o al café. Administraciones papeleras que se preocupan más por la forma de un expediente, que por el contenido; un expediente puede pasar por veinte oficinas que desconocen el asunto, hasta que finalmente lo olvidan.

La Argentina vivía un exultante progreso y no tenía plena conciencia de su futura crisis. Buenos Aires era según Olimpio Pitango "un maravilloso Gargantúa" (156). Visión que reproducía prematuramente un mundo dado vuelta en los años en que la Argentina figuraba entre los países de mayor desarrollo económico. ${ }^{79} \mathrm{La}$ novela cobra así gran actualidad pues las denuncias emitidas en 1915 detectan los males de la Argentina actual: la inestabilidad económi-

${ }^{78}$ Esta quiebra de la ética por el inmigrante en la Argentina sería testimoniada más tarde por la sociología: "The immigrant had simultaneously broken his ties with his birthplace and abandoned the system of norms and principles that had regulated his conduct. Both as a citizen and as an ethical being, the immigrant was a person uprooted, to whom his adopted country, because of its scanty population and level of development, could not offer an explicit, fixed, social and moral structure to replace that of the land he had forsaken (José Luis Romero, ob. cit., 174).

79 Levene describe la atmósfera de exultante optimismo previa a la crisis de 1930: "Tranquilidad institucional; avances en la perfección de las prácticas de la democracia política; prosperidad económica y financiera; ganados y praderas con trazos definitorios de ampulosa riqueza; ... Sí, el país avanzaba con tal soltura que no cabía dudar de su futuro" (Gustavo Levene, Historia Argentina, t. III [Bs. As., Editorial Campano, 1964], 234). 
ca, la burocracia, la ausencia de valores éticos en una sociedad no preparada históricamente para vivir procesos democráticos.

\section{FIJACIÓN DEL TEXTO CRÍTICO}

\section{EL MANUSCRITO}

La presente edición de OPM se hace sobre el manuscrito autógrafo de un texto nunca publicado. A tal efecto se considera todo el material documental que ilumina el proceso de la escritura, el paratexto. $80 \mathrm{El}$ manuscrito, de letra inglesa caligráfica, está compuesto de dos cuadernos muy deteriorados, con la mayoría de las hojas desencuadernadas. El primer cuaderno conserva las tapas de cartulina, el segundo las ha perdido, y la página 103, tachada, tiene una gran perforación en el centro.

El primer cuaderno tiene ocho capítulos con números romanos y termina en la página 105; el segundo con ocho capítulos, empieza directamente en la página 106, primera del capítulo nueve. El manuscrito posee un total de XVI capítulos con 192 páginas de 16 por 23 centímetros; la paginación es correlativa hasta la 174, que corresponde al último capítulo. Este capítulo, el XVI del manuscrito, es el cuento "La Princesa Rayo de Luz" que parece haber sido escrito separadamente y luego agregado. Por lo tanto, en las primeras páginas del mismo hay dos numeraciones, es decir 173 y 2 (segunda página del cuento, la primera sin numerar), 174 y 3,175 y 4. A partir de la página 5 , Holmberg no continúa con la numeración correlativa del manuscrito, sino con la del cuento, que llega hasta la página 20 .

En la tapa del primer manuscrito aparece primero el nombre "E. L. Holmberg", el título en el medio, Olimpio Pitango de Monalia, "I", en número romano (primer cuaderno), debajo, "1913", seguido de: "Buenos Ayres". Luego aparece una portada donde se repite el nombre de Holmberg y el título de la novela. A

80 Para la fundamentación crítica de esta edición se sigue de cerca Litterature Latino-Americaine et Des Caraibes du XX Siècle. Thearie et Pratique de L'Édition Critique, Ed. Amos Sagala (Asociación ALLCA XX: Centre de Recherches ibéro-américaines, Université de Paris X, 1988), especialmente Giuseppe Tavani, "Metodología y práctica de la edición crítica de textos literarios contemporáneos" (pp. 65-84). 
continuación, sin numerar, está el mapa físico de Monalia, y en página enfrentada está el reclamo dirigido al lector que se inicia con el epígrafe en francés, firmado por Ladislao Kaulitz. La paginación empieza a partir de la primera página del primer capítulo.

Holmberg ha escrito de un solo lado de la página; el dorso de la misma está en limpio, excepto en aquellas que él ha usado para introducir cambios o enmiendas correspondientes a la página enfrentada o a la página anterior. Estos agregados y enmiendas prueban que Holmberg no pasó a limpio los borradores. En la mayoría, las correcciones son hechas al correr de la pluma y eliminan erratas propias de una escritura rápida; otras veces, las enmiendas descartan vocablos más cultos por otros más expresivos o populares. Los agregados en las páginas enfrentadas, productos de una relectura y de la reflexión, introducen importantes cambios, como la reestructuración de los infiernos, que analizo en las Variantes.

Hay indicaciones para la imprenta a lo largo del mismo relativas al tipo de letra y presentación del contenido. Inclusive Holmberg ha dejado diseñada la cubierta del futuro texto, en la página enfrentada a la 174 , la que se reproduce en esta edición. En esta cubierta aparece el nombre: E. L. Holmberg; el título: Olimpio Pitango de Monalia; en el medio hay dibujada una cabeza, y debajo de ella está escrito: "Cachîbo Pérez" con la rúbrica de esta firma (que es la que también aparece dibujada en la página 120 y que fue interpretada por Olimpio Pitango). Por último el año: "1915”, seguido de: "Buenos Ayres", y del nombre de la imprenta, ilegible por supuesto.

La afición de Holmberg hacia el dibujo, que él tanto desarrolló por su especialidad en las ciencias naturales, aparece en el manuscrito no sólo en el diseño de la portada y del mapa de Monalia, sino a lo largo del texto. En el reverso de la página 63 hay un grupo de seis hombres de medio cuerpo, probablemente políticos, la mayoría de perfil, en actitud de escuchar o ver algo. Como este dibujo aparece en el capítulo VI sobre el gobierno de Moloso en Molenia, es probable que haya querido representar a su gabinete nacional. En el ángulo superior izquierdo del capítulo XIV, "En plena organización política. El alma de las repúblicas sudamericanas", hay un pequeño dibujo cómico, una mujer cuyo cuerpo es un gran escudo con estrellas en el centro, y con muchos brazos, que son los mástiles de distintas banderas. 


\section{MATERIAL PARA-TEXTUAL}

El material para-textual que aporta datos sobre la producción y la fecha de conclusión de Olimpio Pitango es:

1. Dos recortes de periódico: "1811-Revolución del Paraguay" y "Recibimiento del ejército" (La Razón, 14 de mayo de 1912) que Holmberg pegó en el dorso de la página 11 del manuscrito.

2. La extensa nota en las páginas enfrentadas a las 143,144 y 145 del manuscrito, que Holmberg escribió en una lectura posterior, reproducida aquí en el Apéndice.

3. El artículo "El encarecimiento de la vida de Buenos Aires" (Fray Mocho, 25 de octubre de 1917), que reproduce parte de una carta de Olimpio Pitango a Toribio Albarda.

4. El artículo "Cumple 75 años en estos días el doctor Eduardo L. Holmberg, prototipo del sabio y del maestro en la Argentina" (La Razón, 22 de junio de 1927).

Los dos recortes del periódico La Razón, pegados por Holmberg al dorso de la página 11 del manuscrito, se titulan "1811-Revolución del Paraguay" y "Recibimiento del ejército". Al margen de éste Holmberg ha escrito: "La Razón, martes, mayo 14 de 1912". Efectivamente ambos recortes pertenecen a $L a$ Razón y fueron publicados en esa fecha: el primero en la sección "Efemérides. Fastos americanos", p. 13; el segundo forma parte de la sección "Sucesos paraguayos. La última jornada de la revolución. El ejército vencedor”, p. 9. Como ya comenté en la nota 73 de este estudio, el primer artículo informa sobre el movimiento emancipador del Paraguay, iniciado por la presencia de Belgrano, que inspiró en 1811 el sentimiento de libertad. La revolución libertadora en Paraguay fue el 14 de mayo y el día de la Independencia el 15 de mayo. El segundo recorte alude al recibimiento del ejército vencedor de la Revolución que depuso al presidente, el coronel Jara en 1912, que coincide con el aniversario del movimiento emancipador.

¿Qué valor tienen estos dos recortes para el proceso genético de la obra? Probablemente estos acontecimientos sudamericanos, que Paraguay al cabo de un siglo todavía viva revoluciones de inestabilidad institucional, tengan que ver con toda la reflexión histórica presente en la novela, como ya lo apunté. Pero además, la cronología de la novela empieza con el año 1912. Estos artículos Holmberg los pegó en el capítulo titulado "Un artículo incendiario. Fervor 
político", que describe la influencia que tuvo Olimpio Pitango sobre la población: su artículo despertó la necesidad de una nueva organización institucional. Este liderazgo de este nuevo héroe, se puede comparar al realizado por Belgrano en 1811 "que logró inspirar al general paraguayo y a sus oficiales el sentimiento de libertad" y poco después iniciaron la revolución emancipadora ( $\mathrm{LaR}$ zón, “1811-La Revolución del Paraguay”, p. 13).

Lo anterior permite asumir que la novela se empezó a escribir en 1912. Hay otros hechos que confirman esta fecha. La presencia en el texto de expresiones que indican que Holmberg está escribiendo en el año 1912, así:

a. En el capítulo VI en el decreto del gobierno de Monalia fechado el 15 de mayo de 1912, se convoca a un plebiscito para "el día $1^{\circ}$ de Junio del año corriente” (p. 113, el énfasis es mío).

b. En el capítulo X, la carta de Olimpio del 23 de julio empieza: "La China, mi caro Toribio, se ha convertido en República" (134). La China se convirtió en República en 1912, después de la dinastía de los manchúes.

c. En la misma carta del punto anterior, Olimpio dice: "Mutsuhito es el primer ciudadano, el primer patriota, el padre de los japoneses que lo adoran con la razón y no con el sentimiento ciego" (135). Mutsuhito fue emperador de Japón desde 1867 a 1912; el uso del presente todavía en 1912 indica que aún no se había producido el deceso del emperador, el que ocurrió en 1912.

Los otros materiales para-textuales mencionados arriba aportan datos sobre la fecha de finalización de la novela. ¿Cuándo se terminó $O P M$ ? El año que figura en el diseño que Holmberg dejó de la cubierta del futuro texto, 1915 , crea un problema. Holmberg escribió 1913 en la tapa del primer cuaderno; en el segundo cuaderno está la nota escrita en la página enfrentada a la 143, donde expresa: "Escribí este libro en 1913 y no lo publiqué entonces por cualquier motivo" y más adelante: "No pensaba al terminarlo que habría de publicarse en 1915".

En 1927, al cumplir 75 años, declaró de OPM: "Hace diez años le puse punto final, y no le he vuelto a tocar, más que para releerlo en mis ratos perdidos. Sin duda no he de publicarlo nunca" (La Razón, ob. cit., col. 3). Según esta declaración, terminó OPM en 1917.

En 1917, la revista Fray Mocho, que publicó independientemente parte de la carta de Olimpio Pitango a Toribio Albarda, con las observaciones acerca del abaratamiento de la vida en Buenos Aires, la introduce así: 
He aquí la primicia de un curiosísimo libro del doctor Eduardo L. Holmberg, inédito aún, aunque terminado en 1913, bajo el título de Olimpio Pitango de Monalia (Fray Mocho, "El encarecimiento de la vida en Buenos Aires", oct. 25, 1917, año VI, N²87).

Aunque Fray Mocho repite aquí el año 1913,81 creo que el diseño de Holmberg de la cubierta - hecho probablemente al terminar la novela, pues aparece en el dorso de una página escrita en el segundo cuaderno (páginas en blanco usadas generalmente para las variantes del texto) - es el que más se acerca a la realidad. Es decir, Holmberg empezó la novela en 1912, escribió durante 1913 y la terminó en 1915, introduciendo variantes en lecturas posteriores del manuscrito, que es lo que de alguna manera él declara en la extensa nota inserta en el manuscrito.

Ctros datos confirman que OPM no fue concluida en 1913. Primero, en la nota de la página enfrentada a la 143 del manuscrito alude a la Primera Guerra Mundial (1914-1918) en varias ocasiones:

A los muy pocos días de iniciarse la guerra [...]

La terminación de la guerra en Europa devolverá por algún tiempo a sus hogares a los sobrevivientes, porque en realidad no se trata de que Alemania se quede o no con Bélgica y con Polonia [...] se trata del dominio del Mundo entero y en el mundo está Monalia. Olimpio Pitango [...] [h] abía previsto un peligro.

No se crea, sin embargo que la guerra actual haya influido en lo mínimo en la redacción de este libro [...]

Si el autor escribiera un libro influenciado por la actual guerra [...]

Segundo, hay en el texto otras indicaciones que prueban que en 1913 todavía estaba escribiendo la novela:

1. Cuando alude a: "las elecciones del 30 de marzo de este año de 1913 (p. 158 4/5 del manuscrito). 82

81 Este artículo de Fray Mocho, que ofrece variantes con respecto al manuscrito autógrafo de Holmberg (véase p. 62), lo ha reproducido recientemente Stella Marys Ballarini en Diagnóstico de enfermedad crónica. La crítica social en algunos textos de E. L. Holmberg (Mendoza, Argentina, Cectla, 1989). En esta oportunidad Ballarini expresa: "Fray Mocho asegura que Holmberg concluyó el Olimpio Pitango... en 1913 " (7).

82 En la página 158 Holmberg introdujo un largo agregado de tres páginas que numeró: $1581 / 2,1583 / 4,1584 / 5$. 
2. En la nota a la página enfrentada a la 143 del manuscrito, cita el artículo "Danger" de Conan Doyle, publicado en febrero de 1913 en Fortnightly Review.

En esta nota se refiere a la idea generatriz de la novela, aunque también es difícil establecer el año. Holmberg informa:

Me encontraba en la Inspección General de Enseñanza Secundaria, [...un] Profesor refería las peripecias de un cerebro en el cual persistieron las exteriorizaciones del lenguaje parlamentario mucho tiempo después de la cesación del mandato [...] Esa misma noche [...] encontré una carta de Carlos Correa Luna, "Doctor, necesito una página suya para Fray Mocho". Claro! Ya tenía el tema y me senté a escribir [...el] primer capítulo de este libro. Pero eso no era lo que me pedía el Director de Fray Mocho. Había deseado ubicar, localizar al personaje a que antes aludí y el cuadro resultó demasiado grande para él [...] al cerrar ese capítulo primero, el libro todo estaba bocetado.

Como se vio en la Cronología, Gálvez y Pagés Larraya mencionan el cargo de Inspector de Enseñanza Secundaria entre los años 1905 y 1910 (véase nota 43 de la Cronología). Pero la declaración arriba citada crea otro problema: ¿todavía era Inspector en el año 1912?

Por otro lado, importa esta nota de Holmberg porque a través de ella se sabe que la idea inicial de la novela - la anécdota del profesor sobre ese personaje en el cual persistía el lenguaje parlamentario, después de finalizado el cargo- fue transformada en el proceso de la escritura: "La imaginación, al separarse de las primeras intenciones por las interferencias de una filiación de ideas complejas y múltiples me había hecho olvidar el tema" (nota página enfrentada a la 143).

Un estudio del manuscrito autógrafo -que es un borrador, pues Holmberg no lo pasó a limpio- evidencia que no se trazó un plan previo. Holmberg pertenece a ese grupo de escritores que "proceden un poco al azar como si la escritura fuese un camino que se va creando mientras se transita". .83

83 "Según lo que nos muestran esquemas y borradores existen dos clases de conductas entre los escritores. Hay los que establecen un plan previo (Flaubert, Zola, Galdós) y luego lo desarrollan con mayor o menor sujeción; hay los que proceden un poco al azar, como si la escritura fuese un camino que se va creando mientras se transita, con atajos imprevistos, retrocesos, vuelcos, meandros, sorpresas fulgurantes. A este último tipo corresponde la novelística de Julio Cortázar". Ana María Barrenechea, “Estudio preliminar”, en: Julio Cortázar, Ana María Barrenechea, El cuaderno de Bitácora de Rayuela (Bs. As., Edit. Sudamericana, 1983), 18. 
Corroboran este juicio los errores que se observan en la estructura. Holmberg repite la numeración romana de los capítulos en dos oportunidades: hay dos capítulos IV, y luego dos capítulos VI; después del capítulo XIII salta al XV. Hay inconsistencia en los títulos: todos los capítulos tienen títulos excepto el III, el VIII y el XIII.

La secuencia temporal presente en el manuscrito también revela vacilaciones. Holmberg se preocupó de precisar los acontecimientos detalladamente, a veces día por día. La narración cronológica de los sucesos empieza en el capítulo III, el $1^{\circ}$ de marzo de 1912; al llegar al primer capítulo VI, después de haber arribado al 15 de enero de 1913, retrocede al año 1912, cuando debería continuar con 1913. Como consecuencia de este error, el retorno de Olimpio Pitango a Monalia, en el capítulo XI, debe ser el 28 de febrero de 1914 y no de 1913, como figura en el manuscrito. Esto puede haber sucedido porque Holmberg agregó los años en una lectura posterior, según lo revela el estudio de las variantes del texto.

\section{CRITERIOS SEGUIDOS EN LA PREPARACIÓN DE ESTA EDICIÓN}

Esta edición está basada en los dos cuadernos borradores autógrafos del manuscrito de la novela. Aunque una edición que se realiza sobre un testimonio único puede ser simple, en este caso la fijación del texto ha sido una tarea ardua por momentos, debido al mal estado de los cuadernos, que hacía difícil la lectura, y al hecho de que Holmberg no pasó a limpio estos borradores.

La presente edición respeta la versión última del autor, que es la que aparece como texto aquí. Se han enmendado los errores que hubieran sido advertidos por Holmberg, si hubiera pasado a limpio el manuscrito. Ellos son los referidos a la secuencia cronológica, y a la numeración de los capítulos, ya mencionados en el apartado anterior.

Los capítulos van generalmente precedidos por títulos explicativos que resumen los aspectos a desarrollar. En algunos capítulos sin títulos (III, VIII y XIII) productos del desdoblamiento de otros, estos títulos aparecen enunciados en el capítulo anterior. En estos casos se ha titulado el capítulo trasladando del capítulo anterior el título correspondiente.

Los cambios más importantes introducidos por Holmberg son el resultado de lecturas posteriores y aparecen en el manuscrito en las páginas en blanco enfrentadas a las escritas. Hay además cons- 
tantes correcciones de palabras y de expresiones, en un afán de evitar usos descuidados. Por ser todo esto un reflejo del proceso genético de la novela, se lo consigna en la sección titulada Variantes, con un estudio de los principales tipos de variantes.

Con respecto a parte de la carta de Olimpio Pitango a Toribio Albarda, fechada el 9 de setiembre de 1913, que fue publicada, sin fecha, en la revista Fray Mocho (oct. 25, 1917, $N^{\circ} 287$ ), por representar una versión posterior mucho más cuidada se la incorpora en el texto aunque no en su totalidad. Holmberg, al separar fragmentos de una carta más extensa, realizó una serie de cambios que responden a la naturaleza de este medio de publicación, la revista Fray Mocho, y que alteran el contenido del texto: introduce una nota a pie de página, dirigida al director de Fray Mocho, y alude al final a preguntas de una carta anterior, inexistentes en el manuscrito. Esta carta de Toribio Albarda, fechada el 5 de setiembre de 1913, precede a la de Olimpio.

Las notas explicativas del texto, a pie de página, esclarecen nombres y circunstancias mencionadas por Holmberg, al mismo tiempo que iluminan el bagaje cultural del autor; estas notas aparecen la primera vez que se registra el término. Para no demorar demasiado la lectura del texto, no se dan notas explicativas de los nombres más conocidos de la literatura universal (Shakespeare, Cervantes) y de la música clásica (Bach, Mozart, Beethoven). Los datos editoriales de la bibliografía mencionada en las notas, aparecen la primera vez que se acude a ellos; al citarlos nuevamente se da el título abreviado y la página correspondiente. Se incluyen también a pie de página las notas de Holmberg, con la aclaración de Nota del Autor. La extensa nota escrita en las páginas enfrentadas a las 143, 144 y 145 del manuscrito, se reproduce en el Apéndice.

Muchas veces los nombres estaban alterados por cambios de omisión, adición o inversión de fonemas, lo que retardó la identificación de los mismos para las notas explicativas. Erratas que aparecen corregidas en el texto. Holmberg, ávido lector, confiaba mucho en su gran memoria, que más de una vez le hizo algunas jugadas.

Se respetan en su totalidad la puntuación y el uso de mayúsculas, porque representan un rasgo estilístico del autor. Se han modernizado la grafía (uso de $g, j, y$ ) y acentuación. Mucho cuidado se ha tenido, al fijar el texto, de estudiar detenidamente algunos pasajes ilegibles y confusos, para reproducir con la mayor exactitud la realidad planteada. 
Deseo expresar mi agradecimiento a Laura Holmberg de Parkey Newbury, la nieta del autor, quien me facilitó el manuscrito autógrafo y me brindó generosamente escritos inéditos y documentos personales de Holmberg. Especial reconocimiento debo a Ricardo Arias por la lectura del manuscrito de esta edición y sus valiosas observaciones. Vaya mi profundo agradecimiento a mi esposo, George Castellanos, que me auxilió en la programación de esta edición en la computadora; al padre diácono del convento P. P. Pasionistas de Tafalla, Navarra, que me brindó el inhallable Catecismo de Astete; a las siguientes personas que en distintas ocasiones me asistieron durante el proceso de gestación de esta edición: Martha Barbato, Claude Cymermann, Angela Dellepiane, Jean Macary, Nelly E. Marún, Alina y Julio Zolezzi; y al Dr. Gregorio Weinberg, director de Ediciones Solar, y a sus colaboradores, por la revisión profesional de las pruebas.

GIOCONDA MARÚN

\section{BIBLIOGRAFÍA}

En 1922 Cristóbal M. Hicken, discípulo de Holmberg, publicó una bibliografía sobre la obra científica y literaria de Holmberg. ${ }^{84}$ La científica, que no se abordará aquí, abarcaba las distintas ciencias que Holmberg estudió e investigó: medicina, mineralogía, geología, botánica, zoología, arqueología. Aunque muchos títulos le fueron proporcionados por Holmberg, faltaba en muchos otros la indicación bibliográfica precisa, búsqueda de fuentes completada por Hicken.

Esta labor tiene el valor de ser la primera noticia bibliográfica totalizadora sobre la obra de Holmberg. Sin embargo, en lo que respecta a las obras literarias, la nómina está incompleta y a veces las fechas de publicación son incorrectas. Hicken, por sus afinidades científicas con Holmberg, le dio más importancia a este aspecto que al literario.

La bibliografía sobre la obra literaria de Holmberg que doy a continuación es el producto de horas de rastreo y compulsa de periódicos y revistas en las cuales Holmberg publicó. Su fecundidad

${ }^{84}$ Cristóbal Hicken, Bibliografía del Dr. Eduardo Ladislao Holmberg. Extracto de Darwiniana, vol. I (Bs. As., Coni, 1922), pp. 7-21. Esta bibliografía fue reproducida por Luis Holmberg, Holmberg. El último enciclopedista (ob. cit.) pp. 165-180. 
fue tan vasta que escribía y publicaba simultáneamente en más de un periódico y revista.

Aunque se han consultado todos los periódicos y revistas a los que Holmberg mandaba sus contribuciones, es posible que la nómina de ellos suministrada por Holmberg en su Foja personal (ob. cit), confirmada luego por Hicken y ampliada más adelante por Pagés Larraya, en su edición de los Cuentos fantásticos de Holmberg (ob. cit.) esté incompleta. Esta suposición no es del todo arbitraria, pues muchas veces encontré publicaciones que no habían sido mencionadas por ninguno de los tres. Este es el caso de $L a$ Revista literaria (1879), que descubrí en el Museo Mitre, que no aparecía en la nómina de las revistas a las que Holmberg contribuía. Aquí Holmberg publicó "El periódico liberal" (1879), que erróneamente Hicken lo da como una publicación en una revista de Navarro Viola en 1884.85

Gran parte de las obras que se publicaron en periódicos y revistas, muchas de las cuales se dan a conocer aquí por primera vez y que van marcadas con un asterisco (*), formarán parte de otro volumen en preparación en estos momentos: Obras inéditas de Eduardo L. Holmberg recogidas de periódicos y revistas argentinas.

\section{OBRA LITERARIA DE EDUARDO L. HOLMBERG}

Se consigna la primera publicación del texto, salvo en aquellos casos durante la vida de Holmberg en que luego de haber aparecido la obra en la prensa, se editó como libro.

* “Clara”, El Porvenir Literario, oct. 1, 1872.

Dos partidos en lucha. Fantasía científica. Bs. As., Imprenta de El Argentino, 1875.

Viaje maravilloso del Señor Nic-Nac. Fantasía espiritista. Bs. As., El Nacional, 1875.

* "Insomnio", La Ondina del Plata, feb. 13, 1876.

“El ruiseñor y el artista”, La Ondina del Plata, jun. 18, 1876.

* "El piano de Elvira", set. 15, 1876, en manuscrito.

"La pipa de Hoffmann", El Plata Literario, jun. 15, 1876.

* "El tipo más original”, El Álbum del Hogar, jul. 21, 1878 (inconcluso).

* "Umbra”, La Nación, agos. 18, 1878.

"Boceto de un alma en pena", La Nación, agos. 25, 1878.

“Olga”, La Nación, set. 1, 1878. dista, 177.

85 Cristóbal Hicken, "Bibliografía”, en: Holmberg el último enciclope- 
" "El periódico liberal", Revista literaria, set. 14, 1879.

Horacio Kalibang o Los Autómatas. Bs. As., Imprenta de El Álbum del Hogar, 1879.

* "Política callejera", Nueva Revista de Buenos Aires, vol. I, jun., 1881, pp. 385-394.

"Filigranas de cera", La Crónica, abril 7, 1884.

"La ciudad imaginaria", La Crónica, abril 14, 1884.

* "Dirritío. Rodeando el fogón", La Crónica, jun. 18, 1884; El Nacional, agos. 19, 1887.

* "Kiyué. Rodeando el fogón”, El Nacional, marzo 11, 1887.

La noche clásica de Walpurgis. Bs. As., Imprenta Pablo E. Coni, 1887.

"El reloj de la muerte" (fragmento de La casa endiablada), novela inédita, La Nación, jun. 10, 1895.

La casa endiablada. Bs. As., Cía. Sudamericana de Billetes de Banco, 1896.

La bolsa de huesos. Bs. As., Cía. Sudamericana de Billetes de Banco, 1896.

Nelly, La Prensa, enero 27, 1896.

Nelly. Bs. As., Cía. Sudamericana de Billetes de Banco, 1896.

"El medallón", El Tiempo, set. 29, 1898.

"La gallina infecunda", Caras y Caretas, may. 2, 1903.

"Cuando suena la hora", Caras y Caretas, may. 9, 1903.

* "Mire qué gracia", Caras y Caretas, jun. 6, 1903.

"Nunca se supo", Caras y Caretas, jul. 18, 1903.

"Desenlace de un drama", Caras y Caretas, jul. 25, 1903.

* "El sonso de la colmena", Caras y Caretas, dic. 12, 1903.

"Hurones y comadrejas", Caras y Caretas, enero 16, 1904.

"Panoramas y rumores", Caras y Caretas, mar. 12, 1904.

* "Y con jabón", Caras y Caretas, may. 14, 1904.

* El paraguas misterioso, novela en colaboración con: Ingenieros Peña,

Murature, Lorente, Cantilo, Fernández, Bunge, Ghiraldo, Payró,

Ibarlucea, Carlés, Laferrére. Caras y Caretas, set. 24, 1904.86

* "Don José de la Plamplina", Caras y Caretas, abr. 8, 1905.

* "Más allá de la autopsia", Caras y Caretas, mar. 31, 1906.

* "El fantasma", Caras y Caretas, oct. 13, 1906.

* "Lo más natural", Caras y Caretas, dic. 22, 1906.

* "El gran premio", Caras y Caretas, jun. 29, 1907.

"San Bismo", Caras y Caretas, jun. 15, 1907.

* “Transubstanciación”, Caras y Caretas, dic. 19, 1908.

Lin-Calél. Poema. Bs. As., L. J. Rosso y Cía., 1910.

"Manifestaciones", Caras y Caretas, jun. 25, 1910.

"La chocolata", Caras y Caretas, nov. 18, 1911.

86 Según el Catálogo Centralizado de Bibliotecas Municipales de Buenos Aires, existe una novela de Holmberg publicada por la editorial "Los Novelistas" en 1923, con el mismo título, la que no he podido encontrar, ni hallar ninguna otra referencia acerca de ella. 
* "Las luces malas", Caras y Caretas, mar. 25, 1911.

* "Voluntad que mata", Fray Mocho, jul. 26, 1912.

* "Música ofensiva y defensiva", Fray Mocho, oct. 25, 1912.

"Muy difícil", Fray Mocho, dic. 27, 1912.

"Los fantasmas", Fray Mocho, abr. 25, 1913.

"Pero si están ahí", Fray Mocho, oct. 3, 1913.

* "Un fantasma”, La Cruz del Sur, nov. 1913.

“QQuieres que te afeite?, Fray Mocho, may. 7, 1915.

* "El rey enfermo y la cabeza del médico extranjero", s/f, manuscrito.

"Llegará en abril", s/f, manuscrito.

"Marcelino", s/f, manuscrito. ${ }^{87}$

\section{SOBRE EDUARDO L. HOLMBERG: VIDA Y OBRA LITERARIA}

Argerich, Jorge. “A propósito de un discurso." La Ilustración Argentina, set. $30,1882$.

Ballarini, Stella Marys. Diagnóstico de enfermedad crónica. La crítica social en algunos textos de E. L. Holmberg. Mendoza (Argentina), Cectla, 1989.

Cané, Miguel. "Dos partidos en lucha (Fantasía científica) por Eduardo L. Holmberg." El Nacional, Bs. As., feb. 29, 1875.

—, Ensayos. Bs. As., Adm. Gral., 1919 [1877]. 141.

Cortés, Darío. "El ruiseñor y el artista: un cuento fantástico de Eduardo L. Holmberg." Actas del Sexto Congreso Internacional de Hispanistas. Eds. A. M. Gordon, E. Rugg. Toronto, University of Toronto, 1980. 188-190.

“Cosas de duendes." La Nación, enero 8, 1897.

"Cumple 75 años en estos días el doctor Eduardo L. Holmberg, prototipo del sabio y del maestro en la Argentina." La Razón, jun. 22, 1927.

Darío, Rubén. "Versos de Año Nuevo." Caras y Caretas, enero 1, 1910.

-, Autobiografía. Obras Completas, vol. IV, Madrid, Administración Editorial del Mundo Latino, 1918. 127.

Dellepiane, Angela B. "Ciencia y literatura en un texto de Eduardo L. Holmberg." Homenaje a Alfredo A. Roggiano. En este aire de América. Eds. K. McDuffie, R. Minc. Pittsburgh, Instituto Internacional de Literatura Iberoamericana, 1990. 457-476.

-, "Narrativa argentina de ciencia ficción. Tentativas liminares y desarrollo posterior." Actas del IX Congreso de la Asociación Internacional de Hispanistas. Frankfurt am Main, Vervuert Verlag, 1989. 515525 .

87 C. Hiken en su "Bibliografía" menciona otras obras inéditas inhallables: Hilda, El vampiro negro, En viaje por el método de Lituria, y Puerilia. 
-, "Viaje maravilloso del Señor Nic-Nac: Primera novela argentina de ciencia ficción." La Mistica Spagnola Spagna America Latina. Ed. Gaetano Massa. Roma, Dowling College, 1989. 209-231.

-, "Critical Notes on Argentinian Science-Fiction Narrative." Monographic Review Revista Monográfica. 1-2 (1987). 19-32.

"Discurso del Dr. Holmberg. En la inauguración del monumento a la memoria de la señora de Caprile." El Nacional, agos. 1, 1887. 1.

"Dr. Eduardo L. Holmberg. Falleció en esta capital." La Nación, nov. 5, 1937.

"El discurso del Doctor Eduardo L. Holmberg", El Nacional, agos. 7, 1988

"El Dr. Eduardo L. Holmberg." La Crónica, mar. 19, 1885. 1.

"EI libro de Monsalve" en Ernesto Quesada, Reseñas y críticas. Bs. As., Lajouane, 1893. 165-179.

"El ruiseñor y el artista" (estudio y texto). Antología de literatura fantástica argentina. 1 Narradores del siglo XIX. Selección y notas de H. Flesca. Bs. As., Kapelusz, 1970. 118-150.

"En El Ateneo. Conferencia del Dr. Holmberg.” La Nación, set. 26, 1896.

Escalada, Miguel de. "Nelly por el Dr. Eduardo L. Holmberg." La Nación, oct. $6,1896$.

Ferrero, Graciela. El inconsciente en la creación literaria. Rastreo y análisis de cuatro exponentes sudamericanos: Leopoldo Lugones, Eduardo Holmberg, Oliverio Girondo, Felisberto Hernández. Santa Fe, Argentina, Fondo Editorial de la Provincia de Santa Fe, 1980. 33-61.

Gálvez, Manuel. En el mundo de los seres ficticios. Bs. As., Librería Hachette, 1961. 27.

García Merou, Martín. Recuerdos literarios. Bs. As., Eudeba, 1973. 277-280.

Hahn, Oscar. "Eduardo Ladislao Holmberg: del idealismo romántico al positivismo naturalista", El cuento fantástico hispanoamericano en el siglo XIX. Estudios y textos. 2a. ed. México, Premia Editora, 1982. 4861, 138-162.

Holmberg, Luis. Holmberg el último enciclopedista. Bs. As, Francisco A. Colombo, 1952.

"Holmberg versus Beneliche, cuarenta años de observaciones." El Nacional, set. 26, 1887.

"Homenaje al Dr. Eduardo L. Holmberg." Revista del Centro Estudiantes de Ingenieria, 159 (set. 1915), 720-742.

"Horacio Kalibang o los autómatas. Ed. por El Álbum del Hogar". La Nación, enero 26, 1879.

J. A. "A propósito de un discurso." La Ilustración Argentina, set. 30, 1882. 317-318.

König, Irmtrud. La formación de la narrativa fantástica hispanoamericana en la época moderna. Frankfurt - Bern - New York, Verlag Peter Lang, 1984. 66-82.

Litchblau, Myron. The Argentine Novel in the XIXth. Century. New York, Hispanic Institute, 1959. 
Lugones, Leopoldo. "Primera edición. Nelly por E. L. Holmberg." El Tiempo, set. 18, 1896.

Marún, Gioconda. El modernismo argentino incógnito en La Ondina del Plata y Revista literaria (1875-1880). Bogotá, Instituto Caro y Cuervo, 1993.

-. "España en la novela inédita de Eduardo L. Holmberg: Olimpio Pitango de Monalia" (1915). III Congreso Argentino de Hispanistas "España en América y América en España". Buenos Aires, Instituto de Filología y Literaturas Hispánicas, 1993. Actas II: pp. 673-679.

-, "Un mundo al revés: Argentina en el discurso testimonial de Olimpio Pitango de Monalia (1915), novela inédita de Eduardo L. Holmberg." Río de la Plata [París] 11-12 (1991) 127-134.

—, "Historia y ficción en el cuento inédito de Eduardo L. Holmberg: 'Un periódico liberal' (1879)." Discurso literario. Revista de estudios iberoamericanos 2 (1er. semestre 1990) 377-385.

-, "Revista literaria (Buenos Aires 1879) una ignorada publicación del modernismo argentino." Revista Iberoamericana 146-147 (enero-junio 1989) 63-88.

-, "El ruiseñor y el artista: un temprano cuento modernista argentino." Río de la Plata [París] 2 (1986) 107-116.

—, "La bolsa de huesos: un juguete policial de Eduardo L. Holmberg." INTI Revista de Literatura Hispánica 20 (1984) 41-46.

"Mucho antes de morir E. Holmberg quedó consagrado como sabio de América." Crítica, nov. 5, 1937.

Murillo, Mercedes. "Las virtudes fueron los verdaderos pergaminos del sabio Holmberg." El Hogar, dic. 3, 1937.

“Nelly por el Dr. Eduardo Holmberg." La Nación, oct. 6, 1896.

Ortiz, Eduardo L. "Eduardo Ladislao Holmberg." Principios, 2 (mayo-junio 1953) 30-34.

Pagano, León. El arte de los argentinos. Bs. As., Ed. del Autor, 1938. 329. Pagés Larraya, Antonio. Estudio preliminar. Cuentos fantásticos. De E. L. Holmberg. Ed. Antonio Pagés Larraya. Bs. As., Librería Hachette, 1957. 7-98.

—, Los extraños relatos de E. Holmberg." La Nación, mayo 5, 1957.

Palcos, Alberto. "Darwin, Sarmiento y Holmberg." La Prensa, feb. 25, 1945.

Pizzurno, Pablo A. "Eduardo L. Holmberg como educador: un aspecto desconocido de su acción cultural." La Nación, enero 11, 1938.

"Programa." La Crónica, oct. 1, 1883.

"Remedios caseros. Holmberg versus Benelischem." El Nacional, oct. 8, 1887.

Risco, Antón. “Los autómatas de Holmberg.” Mester 2 (otoño de 1990). 63-70.

Robledo, Efraín. “Un octogenario ilustre.” El Hogar, oct. 22, 1937. 16. Santos, Juan [Martín García Merou]. "Palmetazos." [comentario sobre $E l$ tipo más original de Holmberg]. El Álbum del Hogar, mayo 4, 1879. 346. 
Schiaffino, Eduardo. La pintura y la escultura en Argentina 1783-1894. Bs. As., Edición del Autor, 1933. 316.

"Semblanza del sabio argentino Dr. Eduardo Ladislao Holmberg." La Vanguardia, enero 1, 1946. 14.

s.t. Reseña de Dos partidos en lucha. La Nación, marzo 10, 1876.

s.t. Reseña de Dos partidos en lucha. La Ondina del Plata. feb. 21, 1875. 33.

Uriarte, Gregorio. s.t. Reseña de Dos partidos en lucha. Revista literaria, abr. 1, 1875. 111-113.

Vega Belgrano, Carlos. s.t. Comentario de: El maravilloso viaje del señor Nic-Nac. El Plata Literario, mayo 15, 1876. 23. 


\section{EDUARDO L. HOLMBERG \\ OLIMPIO PITANGO DE MONALIA}

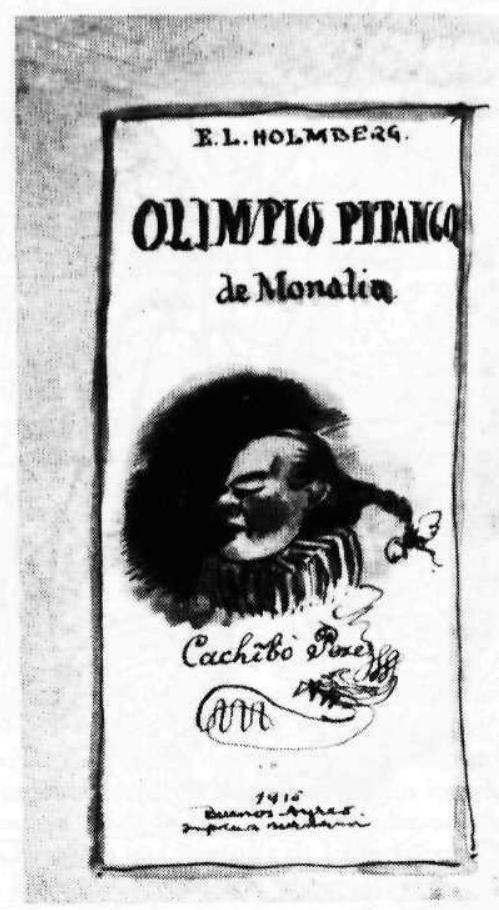

Portada dibujada por E. L. Holmberg (reducción). 


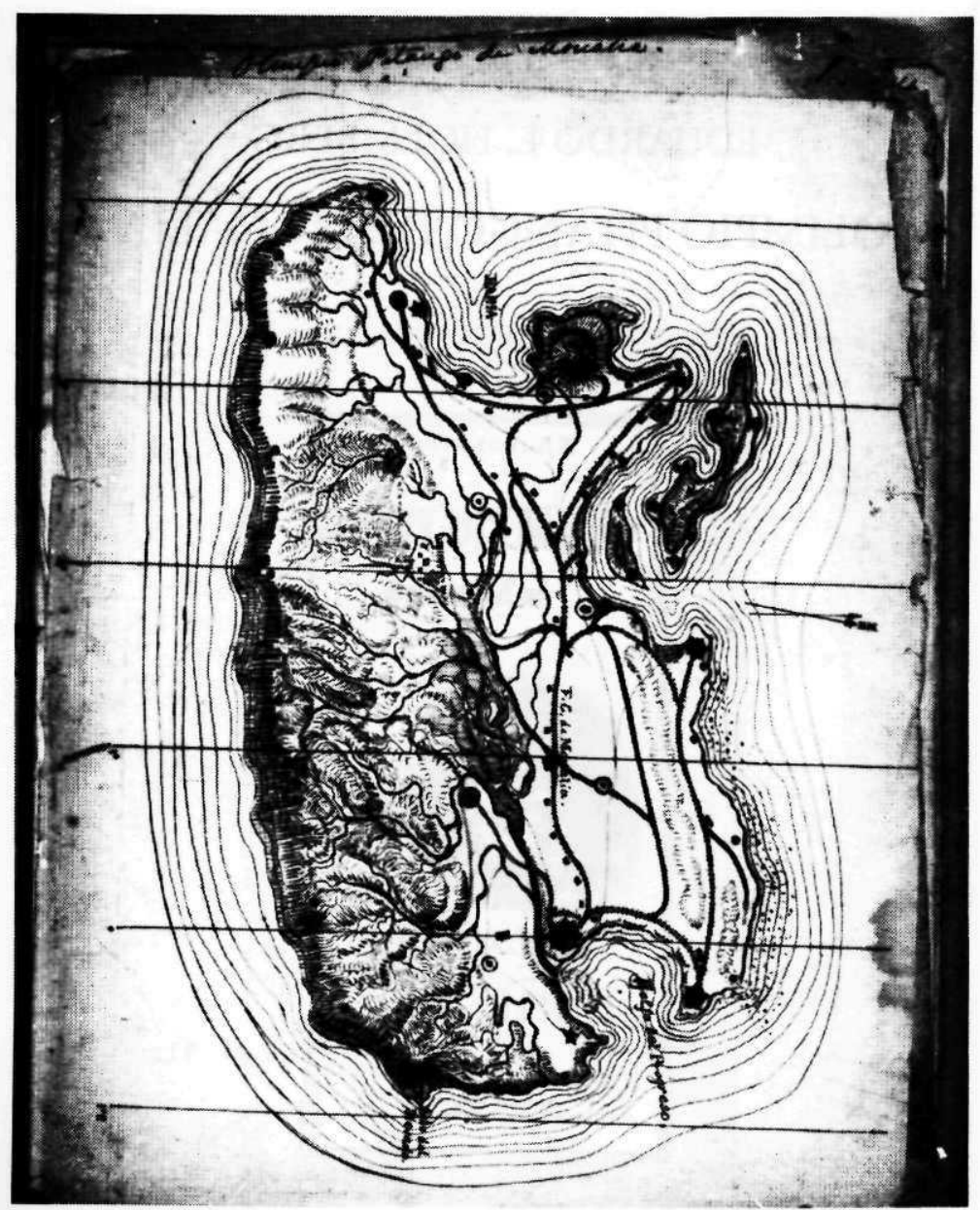

Mapa de Monalia. Dibujo de E. L. Holmberg. 
On vend l'immeuble connu sous le nom de Paradis terrestre avec ses lions. On a fait courir le bruit qu'un des chiens a disparu pendant la nuit dernière, mangé peut-être par un des vieux lions. C'est inexact. Le chien est caché dans un trou de la véranda, pour soigner la petite fille qui va y dormir ce soir comme un garantie de l'inexpérience des lions pour toutes espéces de chairs. Ils ne mangent que du riz. ${ }^{1}$

L. K.

Cuando Goethe experimentaba la necesidad de escribir, no siempre encontraba a mano una cantidad homogénea de papel, y se valía de sobres, reversos de cartas y aun de hojas de envoltorio.

En esa misma época, predominaba el papel de hilo con más o menos rayas de agua, que también se usaba en las imprentas, y que más de una vez, utilizando libros impresos, se han pitado 2 los lectores a falta de chalitas. ${ }^{3}$ En el momento actual nos sobra el papel homogéneo. Lo que nos hace falta son los hombres que piensen como Goethe.

Lector: elige entre el papel y el pensamiento.

Ladislao Kaulitz. leones.

1 En venta el inmueble conocido bajo el nombre de Paraiso terrestre con sus

Se ha corrido la voz que uno de los perros ha desaparecido durante la noche anterior, devorado probablemente por uno de los viejos leones. Es inexacto. El perro estâ escondido en un rincón de la galería, para cuidar a la pequeña niña que va a dormir ahí esta noche como una garantía de la inexperiencia de los leones sobre todo tipo de carne. Ellos sólo comen arroz.

2 pitado: americanismo de pitar, fumar.

3 chalitas: (del quichua challa) los cigarrillos de chala eran los que se hacían con la chala, hoja que envuelve la mazorca de maíz. 


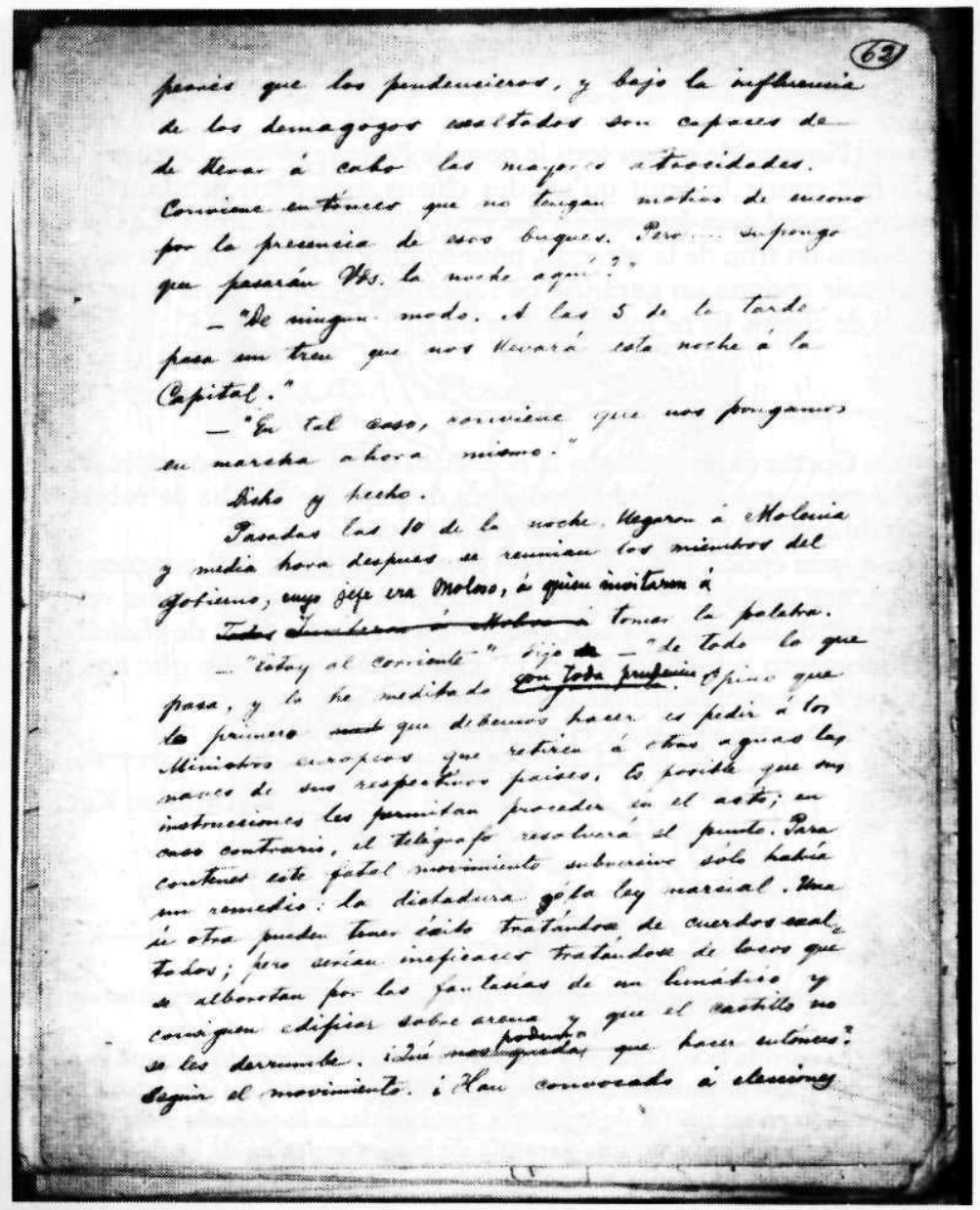

Reproducción facsimilar del manuscrito. 
EL PAÍS DE MONALIA, SU ASPECTO Y RIQUEZA. - EL PUEBLO. - OPINIONES DE ESCRITORES MAL INFORMADOS.

\section{- LOS NUEVOS COLONES.}

Monalia es el país más hermoso del mundo, y todos los poetas y teólogos que lo han visitado han sentido la necesidad imperiosa de considerarlo como un Edén, como el verdadero Paraíso Terrenal. No hay fe que resista. Es inútil presentarles textos sagrados o profanos en los cuales se consigna, casi como un dogma, que el Edén estaba situado en el Asia Menor, entre los ríos Tigris y Éufrates. Por más profundos que sean los argumentos en contra, por más convincentes que aparezcan las deducciones probatorias respecto de la incongruencia histórica en abrigar semejante opinión, el que ha vivido en Monalia está convencido de que ella fue la cuna bíblica de la Humanidad, aunque sólo sea en estilo figurado.

Y además de su hermosura, predomina por su riqueza. No es, sin embargo, de los países más vastos; pero su topografía, su orientación y fertilidad excluyen la existencia de rivales.

Situada en forma insular en el Hemisferio Sur, limítala cerca del Norte una cadena de colinas cubiertas de viñedos, y en la parte austral se levanta una elevada cordillera cuyo flanco del Norte desciende suavemente como un talweg 4 hasta formar un valle transverso al que bajan innumerables arroyos y torrentes los cuales descargan sus aguas en dos ríos que corren al mar en direcciones opuestas: el uno hacia el Naciente y el otro hacia el Poniente. La abundancia de agua, por la humedad que en la falda se condensa, mantiene una vegetación prodigiosa de árboles colosales en

${ }^{4}$ talweg: (voz de origen alemán) $\mathrm{m}$. Fondo de un valle (Grijalbo Diccionario enciclopédico [Barcelona, Ediciones Grijalbo, 1986]), s.v. 
cuyas ramas se tienden, como cenefas y guirnaldas, enredaderas de diversos tipos; cúbrense las cortezas de musgos, líquenes y helechos, y los sitios no cultivados de las montañas y del valle sirven de asiento a una flora variadísima. Las praderas, por otra parte, son ricas en ganados, mientras que, en las poblaciones, aprovecha la industria toda la materia prima del país.

El clima no está en concordancia con lo que a su latitud corresponde, pues los vientos cálidos del Norte, engolfados por la Cordillera Austral, elevan la temperatura de modo que las isotérmicas descienden mucho hacia el Sur a lo que se agrega la ventaja del clima marítimo.

Separada del Continente por un hundimiento muy moderno, unos $21 / 2$ grados de longitud, su constitución geológica, su flora y su fauna son continentales, y puede admitirse que el hundimiento se produjo en Verano, si se toma en cuenta la extraordinaria variedad de peces de agua dulce que puebla sus ríos y arroyos; además de numerosas avecillas que difícilmente se atreverían a desafiar con su vuelo ese espacio marítimo de $21 / 2$ grados.

Todo lo que tiene de suave la cordillera en su declive boreal, lo presenta de abrupta y casi vertical por el lado del Sur, donde choca perpetuamente con furia la corriente antártica interrumpida en su camino, y así excava la base de los formidables acantilados, y origina frecuentes derrumbamientos, de modo que no existe en el mundo entero una costa más peligrosa e inabordable. Óyese allí sin parar el áspero graznido de las aves marinas que pululan en bandadas incontables y anidan en Primavera en las grietas del farallón. No hay documento humano que recuerde la presencia voluntaria de una expedición marítima en tan turbulento mar, $y$ hasta la fecha se ignora su profundidad en las proximidades del acantilado, desde cuya cumbre, que con dificultad salvan las nubes antárticas, ascensionistas audaces han visto muchas naves estrellarse en las rocas y hundirse en los abismos sospechados.

Rica, feliz, generosa y caritativa, gobernada patriarcalmente dentro de un concepto clarísimo de la libertad por el equilibrio del derecho y del deber, la Nación Monálica fue universalmente respetada, y las mismas potencias tuvieron el pudor de no inventar ni la necesidad de establecer en sus costas una estación carbonera.

No se crea, sin embargo, que sus habitantes fuesen unos modestos pastores ignorantes y simples, o labradores palurdos o abotagados, sino ciudadanos perfectamente instruidos en todo lo que concierne al ejercicio discreto de las más amplias libertades; pero el 
gran tacto político que más los caracterizaba consistía en haber realizado la libertad sin proclamarla, sin manosearla, sin llenarse con ella los pulmones para convertirla en motivo de canciones populares. Allí la libertad era espontánea, porque las generaciones sucesivas se habían habituado a ella; era una función del organismo individual y colectivo, como lo es el respirar, el sentir y el pensar, y como un goce tan completo de la libertad no puede adquirirse sin el hábito de la posesión y del fundamento, la instrucción pública formaba parte del equilibrio nacional, confiada esencialmente a los hogares como en otros países son los custodios de la religión. Esto facilitaba en extremo la educación de las aptitudes, primero elementales, luego complejas, lo que había dado origen a la existencia de numerosos institutos variados cuya misión era velar por el desenvolvimiento natural y espontáneo de los más aptos.

Muchos escritores ilustrados de diversos países que conocían superficialmente al pueblo de Monalia habían sostenido en gruesos volúmenes que una constitución social semejante sólo podía dar origen a un pueblo pusilánime, porque la virilidad de las naciones, según ellos, surgía históricamente de la lucha. Pero ¿faltaba acaso la lucha en Monalia? Los espartanos, desde chicuelos, habían luchado como unos toros en la plaza pública, y, pueblo militar aristocrático, se había reservado el derecho de mandar y de combatir con las armas, dejando que la instrucción fuera una vil prerrogativa de los ilotas, de los esclavos.

Atenas, deslumbrada por los retóricos, fue más hábil en la lucha de las frases que en los certámenes de gratitud, en los que siempie salió perdiendo; y cuando Roma se enseñoreó del mundo por las virtudes espartanas del vigor y de la tenacidad en la guerra, llevó a su seno esclavos atenienses para ostentar el lujo de una instrucción de que carecía, y se glorificó de entregar la púrpura imperial a los más grandes bellacos que ha producido la corrupción militar y política.

No.

Monalia no tuvo nunca esa clase de virilidad, tuvo las otras.

Monalia tuvo las luchas del trabajo, porque la función del trabajo era orgánica también, y como las diversas aptitudes no engendraban jerarquías sino modalidades, todos los ciudadanos sabían burlarse de las jerarquías, y así realizaron una democracia perfecta, enseñando al mundo que la adquisición plena de una libertad semejante era la fuente más fecunda de todas las virilidades. 
Los autores mal informados sostuvieron que en Monalia no había un pueblo culto, y como la caridad es una de las virtudes más cosmopolitas, se formaron en algunos países asociaciones de diverso carácter para fomentar la emigración temporal a Monalia de cierta clase de representantes de la cultura humana.

Llegó primero a su capital Molenia un historiador famoso que fue recibido con esa dignidad sin melindres que caracteriza a los monalitas, y anunció que daría diez conferencias (palabra que gustó mucho en el país) en el teatro principal: la 1a. sobre Prehistoria Universal, la 2a. sobre la India, la 3a. sobre la China, la 4a. Egipto, la 5a. Grecia, la 6a. Roma, la 7a. etc. etc. Los monalitas, que conocían el origen de las funciones caritativas que el ilustre viajero iba a desempeñar, le manifestaron que era una práctica nacional el hacer acompañar a todo conferenciante extranjero por un ciudadano que lo presentara al público, y que esto se repetiría en todas las conferencias. Agradeció mucho esta distinción y señaló día y hora. Pero en ese día y en esa hora, cuando ambos personajes se presentaron en el teatro, se encontraba éste adornado de tal modo que parecía un Museo de Prehistoria Universal, y lo que faltaba de material estaba representado en telones especiales.

Después de un saludo hecho por el público, sin exceso, pero con la cantidad suficiente de cortesía para ofrecer la bienvenida, tomó la palabra el monalita, presentó al conferenciante, y habló una hora, indicando las principales fuentes bibliográficas en que podía fundamentarse una conferencia semejante, señalando en distintas direcciones los variados objetos o representaciones de los mismos que servirían para ilustrarla, y dedicó la última parte de su discurso a desenvolver la teoría monalita relativa a las diversas opiniones reinantes en el mundo de los eruditos respecto de la evolución del hombre 5 antes de llegar a la aurora de las civilizaciones históricas que habían dejado las reliquias clásicas hoy conocidas, y rozando con brevedad la teoría del lenguaje hablado antes de manifestarse en las tres formas consagradas por los filólogos. ${ }^{6}$

5 El tema de esta conferencia, como el de las siguientes, está directamente relacionado con los amplios estudios de la filología durante el siglo XIX. Definida como la "ciencia de lo conocido" o de la civilización, abarcaba la historia, la religión, las lenguas, las literaturas, las artes, la política y las costumbres sociales. Concepción amplia del término que fue luego limitado al estudio de las lenguas ỳ literaturas clásicas, la literatura y lengua sánscrita, y las lenguas germánicas y románicas.

6 Se alude a las tres teorías originadas durante el siglo XIX con respecto al lenguaje en las que incide el desarrollo de las ciencias naturales durante el siglo XIX 
-Tales son, conciudadanos, los temas que desarrollará nuestro distinguido huésped.

El huésped agradeció con un saludo y habló durante otra hora. Sabía su discurso de memoria, y no se preocupó de mencionar ninguno de los objetos que se le habían presentado para facilitar su exposición.

Al día siguiente, la prensa entera del país se expresó con unanimidad, declarando que todo juicio sería prematuro antes que el distinguido huésped hubiera dado su 10a. conferencia.

La 2 a. se anunció a los tres días. El conferenciante se ocuparía de la India. El ciudadano que hizo la presentación inició su discurso estableciendo las formas continentales probables que precedieron a la actual asiática. Llamó la atención sobre el Continente Gondwana, 7 y después de manifestar las variaciones probables desde un punto de vista geológico, presentó un cuadro breve, pero muy explicativo de las faunas y floras sucesivas que habían precedido a la flora y a la fauna actuales de la India y de los países circunvecinos, esbozando las teorías recentísimas respecto de los habitantes humanos que la han poblado y la pueblan; trató a grandes

y la presencia de Darwin. La primera, considera el lenguaje como producto físico; concepción naturalista del lenguaje, según la cual la lengua semeja un organismo, con una evolución, un desarrollo (período prehistórico) y una decadencia (período histórico), con diversas modificaciones. En esta teoría son las leyes fonéticas las que explican las transformaciones ocurridas en la lengua. La segunda, es una reacción a la concepción naturalista; según ella, el lenguaje es un producto síquico, cuyos fenómenos pueden ser explicados por leyes fonéticas o reglas, pero cuyas excepciones responden a la analogía, modificación de las palabras bajo la influencia de otras sin que sean etimológicamente afines. La tercera concepción del lenguaje, la de los neogramáticos, reacciona contra los lingüistas anteriores que se han ocupado de la lengua, pero no del hombre, como si la lengua pudiera tener existencia fuera de él. Para estos lingüistas la lengua existe para los individuos que la hablan, $y$ todos los cambios acaecidos provienen de ellos. Esta doctrina concilia las dos precedentes uniendo el factor físico - ley fonética - con el factor síquico - la analogía - (Iorgu Iordan, Lingüística Románica [Madrid, Ediciones Alcalá, 1967], pp. 9-35).

7 Gondwana: nombre dado por el geólogo austríaco Eduard Suess al hipotético continente que comprendía África, Madagascar, India peninsular, Australia, Tasmania, la Antártida, y toda Sud América, excepto el extremo oeste y el noroeste, que durante el devoniano y jurásico fue invadido por los océanos. Suess sustenta su hipótesis en el desarrollo similar de la flora, fauna, y ecología. Geólogos posteriores no han aceptado esta teoría y sugieren que los movimientos continentales no pueden haber ocurrido simultáneamente, y que por lo tanto, la similar distribución de la flora y fauna puede deberse a migraciones naturales, o evoluciones paralelas (Encyclopedia Britannica, 24 vols. [Chicago, London, Encyclopedia Britannica, Inc., 1965] 10: 569). 
rasgos del idioma sánscrito ${ }^{8}$ en el que recitó algunos trozos del Ramayana y del Mahabharata ${ }^{9}$ para dar una idea de su riqueza fonética; señaló su ramificación, hace más de 40 siglos, en pracrito y en pali, 10 de los que dio algunos ejemplos; mencionó a grandes rasgos las migraciones arias, explicando lo que significaba idiomas indogermánicos; ${ }^{11}$ estableció la correlación de la poesía india en su vinculación con sus idiomas y su ambiente, y terminó con algunas indicaciones bibliográficas, señalando de paso que, en la Biblioteca Nacional de Monalia se encontraban los 30 tomos publicados hasta ahora de la traducción inglesa del Ramayana y que abrigaba la esperanza de que todos los presentes alcanzarían a ver la traducción completa.

Esta vez el conferenciante hizo un exordio algo más extenso al agradecer a los dos distinguidos profesores que le habían hecho el honor de presentarlo. Pero, al hacer una ligera pausa, el distinguido "profesor" intercaló unas pocas palabras para advertirle que "ellos" no eran profesores sino estudiantes.

Como en la primera, el conferenciante habló una hora. Su discurso fue muy elocuente, muy elegante.

${ }^{8}$ sánscrito: lengua aria que deriva de las indoeuropeas. Los más pretéritos documentos indoarios, Jos textos Védicos, están compuestos en sánscrito. Aunque se desconoce su fecha, es probable que el más antiguo pertenezca a la segunda mitad del año 2000 a.C. Estos textos religiosos fueron conservados por tradición oral. Originalmente el sánscrito se reservó como lengua religiosa, pero a partir del cuarto siglo se usó como lengua secular (E. B. 19: 954).

9 Mahabharata y Ramayana: los dos grandes poemas épicos hindúes del período clásico. El primero atribuido a Vyasa y probablemente del 300 a.C. no es realmente un poema épico, sino una colección de poesías legendarias y didácticas que giran alrededor de una narración central heroica. El segundo, Ramayana, poema cuyo héroe principal es Rama, tiene un total de 48.000 versos de dieciséis sílabas. Su probable autor es el poeta Valmiki (E. B. 19: 962).

10 Pracrito y pali: fueron las lenguas religiosas y seculares de las nuevas sectas antes de que el sánscrito se usase como lengua popular. El pracrito, derivado como el sánscrito del tronco ario, fue usado por los escritores budistas e hindúes desde la tercera centuria antes de Cristo, hasta el cuarto siglo después de Cristo. (E. B. 18: 417). El pali que también deriva de las lenguas indoarias, aparece como la lengua canónica de los escritos de Buda que se conservan en Ceylán, Burma y Tailandia. La lengua deriva como el sánscrito del tronco ario. El sánscrito, la lengua literaria, fue prohibida por Buda para la enseñanza, quizás porque era una lengua inteligible para los que él quería convertir. Debido a la multiplicidad de dialectos, no se ha podido rastrear el origen del pali. Aunque se identifica al pali como la lengua de Magda (India oriental), el lenguaje canónico de los escritos de Buda no está relacionado con el dialecto de Magda (E. B. 17: 145).

11 idiomas indogermánicos: lenguas indoeuropeas. 
Al otro día la prensa entera del país se expresó con unanimidad declarando que hablaba muy bien; que tenía una voz muy simpática y una erudición recomendable.

Pero el clima del país le hizo daño, y los médicos le recomendaron un cambio continental de aire. Y se fue. Cuando llegó a su tierra, escribió varios artículos llenos de reticencias y eufemismos. Habló mucho de la belleza del país; pero dijo que la gente culta era inculta; que los oradores eran unos lateros y que su ignorancia era la propia de los petulantes.

Estos artículos estimularon una vez más a las asociaciones caritativas de diversa índole para fomentar la emigración temporal a Monalia de cierta clase de representantes de la cultura humana.

Le tocó el turno a un crítico musical.

Los periodistas de Monalia, gente que con la mayor facilidad se sulfura, estuvieron bravos en esta ocasión.

Por vez primera, en toda su existencia, emplearon términos insólitos:

Colón musical. Siguiendo el rastro luminoso de un historiador que ignoraba la existencia de los Museos Universales de Prehistoria, viene a descubrirnos un crítico musical. De su primera conferencia resulta que no sabe música. ¡Que nuestro clima le sea benigno!

Llegó después a Monalia un eminente escritor que despertó grande entusiasmo en el público. Anunció varias conferencias sobre El Quijote, y solamente se ocupó de Virgilio12 y de Schiller. ${ }^{13}$ Como el clima le fue benigno, se burló de los habitantes. Un día descubrieron los periodistas que sólo había tenido oyentes de mecánica y bondadosas seriamente especialistas -y como carecían de la práctica de la ironía voltairiana, lo saludaron con el apodo de Colón literario.

Desarrollóse por todas partes la fiebre de los descubrimientos en Monalia, y como a todos esos descubridores el clima les fue benigno, Monalia los adoptó.

12 Publio Virgilio Marón: (70-19 a.C.) el gran poeta romano, autor de Las Bucólicas, Las Geórgicas, La Eneida, que es el poema sobre Roma.

13 Schiller, Johann Christoph Friedrich von: (1759-1805) poeta, dramaturgo y filósofo alemán nacido en Marbach, fue el exponente de la ideología que en Europa corresponde al período previo a la Revolución Francesa. Sus obras tuvieron gran influencia en Jos románticos; entre ellas estản: Don Carlos, María Stuardo, La doncella de Orleans, Guillermo Tell, Historia de la Guerra de los Treinta Años. 
Habíanse infiltrado en sus habitantes las ptomaínas ${ }^{14}$ del exotismo con sus gérmenes correspondientes. Y huyendo de ese peligro, Tupitambo emprendió un viaje al Exterior.

\section{UN ARTÍCULO INCENDIARIO. \\ - FERVOR POLÍTICO}

Monalia pasó por una crisis cuya duración podría llegar a un término inmediato o hacerse indefinida, tomando el carácter de una versatilidad permanente, o desalojando poco a poco los impulsos momentáneos.

Sus periodistas habían gustado por vez primera el fruto picante de la crítica burlona. Los términos casi inocentes de "Colón literario", "Colón científico" con que habían designado a los caritativos invasores que iban a Monalia a disertar sobre asuntos que ésta conocía mejor que ellos, tuvieron un éxito loco. Ni las más sangrientas burlas emitidas desde Aristófanes 15 hasta Mark Twain, 16 pasando por Petronio, ${ }^{17}$ Apuleyo, 18 Boccaccio, ${ }^{19}$ Cervantes, Voltaire ${ }^{20}$ y

14 ptomaína: ciertos alcaloides o bases orgánicos, algunos venenosos, que provienen de la descomposición de las materias orgánicas.

15 Aristófanes: (c. 450-388 a.C.?) el más famoso escritor griego de comedias. Sus obras son a menudo sátiras políticas o literarias, entre ellas: Las nubes $(423$ a.C.), donde ridiculiza a Sócrates, Las avispas, Las ranas, Lisistrata, Los caballeros, etcétera.

${ }^{16}$ Mark Twain: seudónimo de Samuel Langhorne Clemens (1835-1910) importante escritor estadounidense del siglo XIX. Autor de libros de viajes y novelas autobiográficas, entre ellas: The Adventures of Tom Sawyer, The Adventures of Huckleberry Finn, The Prince and the Pauper.

17 Petronio: (m. 66 d.C.) poeta y autor de El satiricón, novela picaresca social de la Roma neroniana, cuya característica narrativa es la fusión de géneros: cuentos, sátira menipea, poesía épica, digresiones donde el autor expone sus propios puntos de vista sobre diversos tópicos.

18 Apuleyo: (siglo II a.C.) filósofo platónico y retórico, autor de la prímera novela latina, El asno de oro, que a partir del Renacimiento ejerció una gran influencia en la novelística posterior.

19 Boccaccio, Giovanni: (1313-1375) escritor italiano, autor del Decameron, conjunción de 100 cuentos cuyos valores humanistas, productos del Renacimiento, emergen sobre una aparente frivolidad temática.

20 Voltaire, François Marie Arouet: (París, 1694-1778) autor de obras teatrales, históricas, filosóficas, poemas, cuentos, novelas cortas. Entre ellas: Discours en vers sur l'homme, Essai sur les moeurs, Siècle de Louis XIV, Candide, Dictionnaire philosophique, etcétera. 
Dickens, ${ }^{21}$ despertaron jamás tanto alboroto. Y resultó lo que tenía que resultar: al verse tan festejados no pudieron menos de engolosinarse. Inventaron términos nuevos y de un modo gradual, casi insensible, llegaron hasta el insulto. Pero nunca fueron venales: jamás recibieron un centavo por el elogio, ni por la defensa, ni por el ataque.

Cierto día, el mejor de sus escritores conmovió a la nación entera con un artículo de proyecciones políticas y sociales incalculables.

La virtud —decía - no consiste en ser virtuoso solamente porque se es ignorante o inocente. La verdadera virtud es una función de la voluntad en presencia y conocimiento del escollo que es el peligro. ¡ Valiente gracia el ser casto a los noventa años! Heroica acción el ser honrado cuando no se manejan dineros públicos o ajenos.

Los monalitas no conocemos los peligros de las diversas formas de gobierno, y mientras no las hayamos ensayado todas estaremos inhabilitados para vituperar a los que nos consideran unos simplones, unos ignorantes, unos primitivos. Nuestro régimen de vida política encuadra de un modo admirable en los tiempos prehistóricos o casi, y si hemos de tomar parte en lo que universalmente se designa como el concierto de las naciones, necesario es ponernos a la par de todas ellas, abandonando las prácticas añejas de un bienestar apolillado.

Nosotros no tenemos próceres, no tenemos himnos, no tenemos ruinas, ni cámaras, ni constitución, ni comités, ni siquiera partidos políticos, lo que es una deficiencia indigna de un pueblo que pretende ser ilustrado; lo único que tenemos es la paz de la edad de oro, el bienestar, la riqueza y la justicia. ¿Para qué nos sirve todo eso si carecemos de la lucha que es una ley fundamental de la vida política? Es necesario que tengamos todo aquello aunque sólo sea para variar los temas de nuestras conversaciones y la aplicación de nuestra dialéctica.

Si carecemos de próceres, los inventaremos; como han hecho otros y como los pueblos son más sugestionables que los individuos, los pueblos acabarán por convencerse de que tienen próceres. Una vez convencidos de su existencia, lo estarán también de sus hazañas; los poetas escribirán himnos en su elogio y en el de la heroica nación que los ha producido, y los escultores fijarán sus fisonomías en el mármol y en el bronce. Surgirán los historiadores de la patria —que nos hagan conocer la evolución de la misma en todas sus formas y dedicarán interminables veladas al estudio de las opiniones y de las sangrientas luchas con que las sustentaron aquellos ínclitos varones de la libertad. Nuestros paleógrafos encontrarán documen-

21 Dickens, Charles: (1812-1870) novelista inglés, uno de los maestros del género, autor de Oliver Twist, Nicholas Nickleby, David Copperfield, Bleak House, Great Expectations, que calan en los aspectos sociales de la Inglaterra victoriana. 
tos justificativos de todos los sacrificios nacionales o los construirán en su defecto; se descubrirán las ruinas que todos los países civilizados han descubierto, menos nosotros, por esa desidia que es prerrogativa del bienestar, y por esa aversión atávica que nos ha caracterizado siempre por todo lo que sea aplicar los procedimientos maravillosos de la plástica moderna a la ejecución de documentos esenciales, concretos, probatorios de las afirmaciones históricas o prehistóricas.

Nuestros archivos están repletos de legajos que nadie consulta porque según los testimonios de lo que podríamos llamar nuestro mundo político, durante tres siglos, no contienen sino documentos de carácter agrario o emanados de los actos de la vida civil. Y esto nos lleva, por la lógica misma de los sucesos, a la convicción de que no pasará mucho tiempo sin que nuestros historiadores indignados pregunten qué se ha hecho con nuestros archivos militares, quiénes han sido sus custodios, y por qué motivo no se ha levantado una voz enérgica que reclame ante el mundo de esa falta de patriotismo, de ese criminal exceso de indolencia, de esa desidia sin nombre que ha dejado perder jay! por ignorancia y por olvido, hasta los mismos estandartes y banderas que inflamaban el corazón de las huestes de la patria, y las que llevaban a la victoria y al triunfo, y en olas del entusiasmo hasta la gloria.

Así dirán nuestros historiadores, y será necesario, para satisfacer su justo reclamo, que nuestros paleógrafos dediquen todo su tiempo, todo su talento reconstitutivo, a llenar ese deplorable vacío.

$¿$ Qué se han hecho las estatuas elaboradas por el genio de nuestros Fidias, ${ }^{22}$ de nuestros Praxíteles?23 ... ¿qué los gloriosos cuadros pintados por nuestros Rafaeles ${ }^{24}$ y Murillos ${ }^{25}$ y Rembrandts ${ }^{26}$ en nuestro siglo de

22 Fidias: (Atenas, 500-431 a.C.) uno de los más grandes escultores griegos. Sus dos obras maestras fueron las estatuas de la diosa Atenea y la colosal representación de Zeus. Aunque Fidias no pudo ser el ejecutor de todas las esculturas del Partenón, se considera que él fue quien las diseñó.

${ }^{23}$ Praxíteles: (Atenas, siglo IV a.C.) uno de los escultores griegos más originales, su escultura más famosa fue Afrodita. A él se debe la transformación de los contornos majestuosos y estéticos de la escultura griega del siglo v, en gráciles y dinámicos.

24 Rafael Sanzio: (Urbino, 1483-1520) uno de los representantes de la genialidad artística del Renacimiento, junto con Leonardo da Vinci y Miguel Ángel. Colaboró en la decoración del Vaticano y sobresalió en la pintura de las madonas, entre sus obras maestras: La Sagrada Familia, La Fornarina, El Pasmo de Sicilia, La Madona Sixtina, etcétera.

${ }^{25}$ Murillo, Bartolomé Esteban: (Sevilla, 1617-1682) pintor de innumerables cuadros religiosos transidos de misticismo: La Inmaculada Concepción, La Visión de San Antonio, San Leandro, San Isidoro, etcétera.

${ }^{26}$ Rembrandt: (Harmenszoon Van Rijn, Leyden, Holanda, 1606-1669) prolífico pintor holandés, sobresalió por la maestría de los efectos de luz y claroscuros, la riqueza de detalles, y la armonía de sus composiciones. Entre sus obras maestras: Tobias y su familia, El samaritano, Los peregrinos de Emaús, Ronda nocturna. 
oro, cuando por toda la nación se difundía ardiente y vibrante la acción progresista de nuestro inmortal Cachimbo Pérez, ese Pericles ${ }^{27}$ de Monalia, que a semejanza del ateniense dio forma y vida a los entusiasmos nacionales después de las victorias de Tipitamba, Sichinta y Sambomba.

¡Despierta, Monalia, de tu sueño secular! haz honor a tu nombre, levántate altiva, reivindicando tus derechos en el pasado, en el presente y en el porvenir.

Semejante artículo leído con entusiasmo y en altas voces por todos los ámbitos de la Nación no fue un grito revolucionario, un llamado vibrante al sentimiento nacional, un estímulo a la eclosión de pasiones en germen: fue simplemente, para el sentido común un artículo de diario, y para Monalia un clarín.

Jamás bronce alguno resonó con más estrépito, ni Quinquendona 28 oxigenada sintió un despertar más tumultuoso, porque cada vez lo leían con nuevas entonaciones más vibrantes y se pensó que aquella era oratoria, elocuencia y verdad; y los oradores, aunque digan disparates, triunfan siempre, si les comunican fuego y entusiasmo, porque las muchedumbres en ciertas ocasiones no necesitan de ideas complejas y expresadas en largos períodos para electrizarse, sino palabras de altísimo sentido patriótico artísticamente distribuidas en el rumor sinfónico de las arengas.

Los agricultores abandonaron la pala y el arado; repudiaron los estudiosos sus libros y artefactos de investigación; los pintores arrojaron sus pinceles y paleta a los rincones, y los escultores sus cinceles y martillos; apagóse el fuego de las fábricas, cesó el ruido de los molinos y telares y ya no se sintió el golpe ni el olor, ni el humo de las fraguas.

Monalia se había levantado estupefacta y electrizada.

27 Pericles: (490-429 a.C.) orador y político ateniense de gran influencia sobre los ciudadanos, jefe del Partido Democrático, contribuyó a la expansión territorial y naval de Atenas. A pesar de la guerra del Peloponeso, durante su liderazgo Atenas obtuvo prosperidad económica y gran desarrollo artístico y literario.

28 quinquendona: neologismo de Holmberg formado a semejanza de quinqueviro (1. quinquevir-iri, de quinque, cinco y vir, varón: oficiales o magistrados romanos, que en número de cinco eran nombrados para distintos cargos de la República); partiendo de esta etimología crea otra semejante (quinquen, cinco y dona, mujer), en este caso irónicamente alude a la mujer oxigenada, al servicio del gobierno. 
No; no se levantaron todos los monalitas.

Frente al desbordamiento de aquella elocuencia de barricada, surgió sereno el espíritu práctico, discreto y tranquilo, inaccesible a las metáforas relumbrantes, conservador de la felicidad y de la paz, del grupo de ciudadanos que constituía el gobierno patriarcal.

En vano procuró demostrar a la nación monalita que iba a sacrificar todo su bienestar perpetuo ante el ara de una pesadilla de fuegos de artificio.

Predicó en el desierto.

Cuando el corazón de un pueblo se enardece las llamas le suben hasta el cerebro y le consumen todo el fósforo, y mientras dura esa combustión, quema, rompe, quiebra, derrumba y destruye cuanto encuentra. Pero los monalitas carecían de experiencia para realizar estas acciones fuera de los fines útiles, es decir les faltaba la técnica del desenfreno, y su furor no tuvo sino consecuencias oratorias. La primera palabra que inició el exotismo fue conferencia, y así, después de los primeros fervores del entusiasmo se resolvió que media nación conferenciara con la otra media. En el país no había jerarquías oficiales dentro de las aptitudes; pero una cosa es la jerarquía que da derechos, y otra la jerarquía que ya los tiene. El incendio fue iniciado por las palabras, y como no todos los ciudadanos tenían la aptitud de propagarlo con ellas, los menos aptos se eliminaron espontánea y sucesivamente, de modo que las conferencias se fueron restringiendo también, hasta que al fin se redujeron a grupos muy limitados, pero en los cuales, en identidad de coeficientes de aptitud con los otros, se perfilaban las ideas que habían sustentado los próceres de "aquellos tiempos gloriosos". Al principio, sólo presentaron albores indefinidos; pero, en el calor de las discusiones, en el chocar luminoso de las frases, hubo tintes de aurora que no alcanzaban a herir las fibras fatigadas de los menos aptos. Éstos, poco a poco, aprovechando los agentes reconstitutivos de la playa marina, de las brisas del valle y sus recursos, o de los bálsamos de los bosques, penetraban cada vez con más vigor y espontaneidad popular en el espíritu de las conferencias que se retintaban con mayor energía gradual, y convencidos entonces de que el solo hecho de haberse repuesto les creaba una autonomía indiscutible, gritaban en todos los tonos: “¡Comités! ¡Comités!”

Y no hubo remedio.

Fue necesario crear los comités.

Pero se presentó un inconveniente, y de los más pesados. ¿Sobre qué base habrían de fundarse esos comités? 
¿Cuáles las ideas que darían el nervio a sus deliberaciones? directores?

Al propalarse estas preguntas hubo un estupor general, y los habitantes de Monalia reconocieron con sorpresa que faltaban bases, ideas, principios y corifeos.

Hubo como una vislumbre de que la elocuencia maligna del escritor los había envenenado, enardecido y cegado al despertar en sus corazones un entusiasmo ficticio.

— ¡No importa! — dijeron entonces los demagogos - fundemos los comités y mantengamos cada vez más ardiente el fuego del patriotismo y gritemos bastante, porque el patriotismo sin muchos gritos no lo comprenden los pueblos, sino cuando se transforma en causa habiendo nacido como efecto.

-Pero el patriotismo, como sentimiento, no ha sufrido jamás en Monalia ni la sombra de un vituperio; ha sido siempre sincero y profundo, íntimo, inherente a la nacionalidad misma - exclamaron todos aquellos que más se inclinaban a la forma de gobierno vinculada a su bienestar de tres siglos.

Y así fue como se crearon los dos primeros partidos políticos en el país de Monalia, sosteniendo el uno que era necesario mantener cada vez más ardiente el fuego del patriotismo, y el otro que el patriotismo en su forma secular era inherente a la vida nacional.

Tomó el primero el título de Partido Patriota; - designóse al segundo con el de Partido Regulador; - y cuando se constituyeron, cuando se crearon comités por toda la nación, sin que quedara un solo ciudadano sin embanderarse, hubo entre ambos un entusiasmo correlativo sin precedente, porque se realizaba una aspiración que sólo el genio había podido descubrir en la forma embrionaria o si se quiere latente en que la guardaban todos los ciudadanos.

Consagróse aquel día como el más grande de la nacionalidad monalita, como el día sagrado de la patria; y cuando resonó el coro inmenso del uno al otro confín insular proclamando el 29 de Febrero ... recién entonces se dieron cuenta de que aquel año era bisiesto y de que no podrían conmemorar sino cada cuatro.

- iNo importa! —exclamaron los Patriotas y los Reguladorestambién nosotros tendremos olimpíadas. El 29 de Febrero será nuestro grito de Ypiranga,29 nuestro 5 de Enero, 2 de Marzo, 15 de Abril,

29 Ypiranga: el Grito de Ypiranga fue la declaración de la independencia del Brasil, a orillas del río Ypiranga (São Paulo), el 7 de setiembre de 1822. 
25 de Mayo, 35 de Junio, 4, 9, 14 y 18 de Julio, 27 de Agosto, 18 y 2 de Setiembre, 39 de Octubre, 80 de Noviembre, 95 de Diciembre, 3 de Metagitnion, 3035 del Ramadán... ${ }^{31}-$ y gritaban cada vez más fuerte mucho más fuerte, que lo que se grita en Lohengrin, 32 hasta que no pudiendo gritar más, al sentir que les iba a faltar el resuello para el grito supremo, estallaron en voz económica pero profunda:

—iAl fin tenemos partidos políticos y comités!

\section{III}

\section{EL MEJOR DE SUS ESCRITORES}

Con tan fausto motivo, por todas partes hubo banquetes en los cuales se comió, se bebió y se gritó; pero también surgió algo nuevo que los monalitas no habían conocido nunca: la oratoria política.

El mejor de sus escritores, el de marras, cuyo nombre sonaba ya en los corrillos como el del jefe probable del Partido Patriota, publicó otro artículo con fecha 1० de Marzo de 1912 en El Patriota..., diario fundado la noche antes para sostener los principios del partido del mismo nombre -y así el $1{ }^{\circ}$ de Marzo conocieron los monalitas algo nuevo (cae de su peso) que nunca habían visto: un diario político.

Ayer 29 - decía - se ha manifestado en forma gloriosa la vitalidad política de la nación, y no debemos ni podemos ocultar que se ha producido un verdadero renacimiento de las antiguas, olvidadas prácticas oratorias que fueron un tiempo prerrogativa de nuestro pueblo, cuando inspirado el Gran Botijo en los más nobles sentimientos, incubados a la lumbre de las altas virtudes del civismo, electrizaba a las masas populares con las joyas irisadas de su elocuencia incomparable. Es verosímil que esas joyas se hayan perdido como tantas maravillas de nuestro pasado; pero la leyenda, la tradición, que valen tanto o más que los documentos, nos presentarán siempre a la imaginación su grande, viril figura, ora conminando a los enemigos presuntos de la libertad, ora apostrofando a los conculcadores

${ }^{30}$ Metagitnion: del gr. $\mu \varepsilon \tau \alpha \gamma \varepsilon \imath \tau v i \omega v$, segundo mes del año ático, según lo registra por primera vez Suidas en su Lexicographus s. X a. C. (A Greek-English Lexicon. Comp. Henry George Liddell, Robert Scott [Oxford, The Claredon Press, 1953]. Vocablo no registrado en la mayoría de los diccionarios y enciclopedias españoles. Espasa Calpe lo incluye pero remite a un derivado, metageitnias, las fiestas en honor a Apolo, celebradas durante el segundo mes del año en Atenas (Espasa Calpe, vol. 34, 1131-1132).

31 Ramadán: el quinto mes del año musulmán cuando el Korán fue enviado como guía para la gente, es el mes sagrado de ayuno.

32 Lohengrin: ópera de Wagner compuesta en 1848 e inspirada en Lohengrin (composición épica medieval alemana de 760 estrofas). 
hipotéticos del sufragio por establecer. ¡Ah! ¡Sí! ¿Cómo no sentirse orgulloso al considerar que el vigor, el brillo, la poderosa sugestión de aquellos próceres de nuestra oratoria renacen en los labios de nuestra juventud entusiasta, como si las leyes del atavismo hubiesen mantenido latente la vitalidad de los modelos inmortales que consolidaron para siempre las instituciones de Monalia? Al escuchar anoche, en distintos banquetes, las improvisaciones de los oradores juveniles humedecíanse los ojos de los ancianos, como si obedeciendo a la entonación imperativa de las evocaciones, se les hubiera presentado la no olvidada imagen tradicional de Botijo.

Pero lo que da más brillo a la fecha ya consagrada del día 29 de Febrero es la aptitud insospechada del pueblo para constituir, por un prodigio de actividad patriótica, los dos bandos que se repartirán en adelante la dirección política de Monalia; pero más, mucho más, la rapidez casi fulmínea con que se han organizado en todos los pueblos los comités locales.

Debemos lamentar empero que un accidente de almanaque no nos permita conmemorar todos los años la gloriosa fecha. No importa por ahora. Al iniciarse nuestra vida institucional, vislumbramos, en un futuro muy próximo, las decisiones parlamentarias a su respecto....

Olimpio Pitango

***

Los Reguladores no comentaron este artículo en su diario $\mathrm{El}$ Regulador. Ni se ocuparon de él.

Pero fue devorado por Los Patriotas.

Apenas leído, se transmitió por telégrafo no sólo a los más apartados rincones del país, sino también al exterior, como lo había sido el primero, que provocó el despertar de Monalia. Su lectura produjo un cisma en el Partido Patriota.

La mitad de los partidarios se segregó formando un nuevo partido: Los Insistentes, que sostenían la celebración anual de la fecha.

Los no cismáticos conservaron el nombre de Los Patriotas, aceptando la sugestión de las olimpíadas.

Los Reguladores, por su parte, y malograda la insistencia adversa de los elementos directivos, tuvieron su cisma también, porque, si bien es cierto que un grupo importante no aceptaba en forma alguna la propaganda de Olimpio Pitango, otro, no menos numeroso, tenía sus veleidades por el estilo aflautado del escritor, y constituyendo otra agrupación con el nombre de Los Olimpicos se distanció de Los Re- 
guladores los cuales no se habían preocupado mucho ni poco de los períodos de conmemoración. Pero Los Olímpicos no pudieron entenderse, porque los unos aceptaban la celebración anual y los otros las olimpíadas, en lo que coincidían con Los Patriotas. Entonces, los que aceptaban las olimpíadas, conservaron el nombre de Olimpicos, y los otros, los de la conmemoración anual, formaron dos grupos: Olímpicos de Febrero y Olímpicos de Marzo, que sostenían, los primeros, la conmemoración el día 28 de Febrero y los segundos el 10 de Marzo -dando los unos razones tan buenas o tan malas como las de los otros. Los Insistentes, disgregados de Los Patriotas, discreparon también y en la misma forma, constituyendo tres grupos: 10. Los Insistentes februarios que adoptaron la conmemoración el 28 de Febrero en los años no bisiestos; $2^{\circ}$. Los Insistentes marciales el 1० de Marzo; y 3o. Los Insistentes terciarios que querían la celebración del 28 y del 10 siempre, más el 29 de Febrero en los bisiestos.

En lo que todos estaban de acuerdo, sin embargo, era en la conmemoración solemne del 29, estableciendo que en tal fecha, se haría caso omiso de todos los distanciamientos que pudieran originarse por la evolución y generación creciente de los partidos.

$\mathrm{Y}$ téngase en cuenta que todos estos cismas ocurrieron en menos de dos días, porque el 3 de Marzo El Regulador y El Patriota daban cuenta de ellos a sus lectores, con tan poca suerte, sin embargo, que nadie se entendía. Entonces convinieron en que cada uno señalara las escisiones de su partido; pero aquí podemos establecerlas en forma sinóptica:

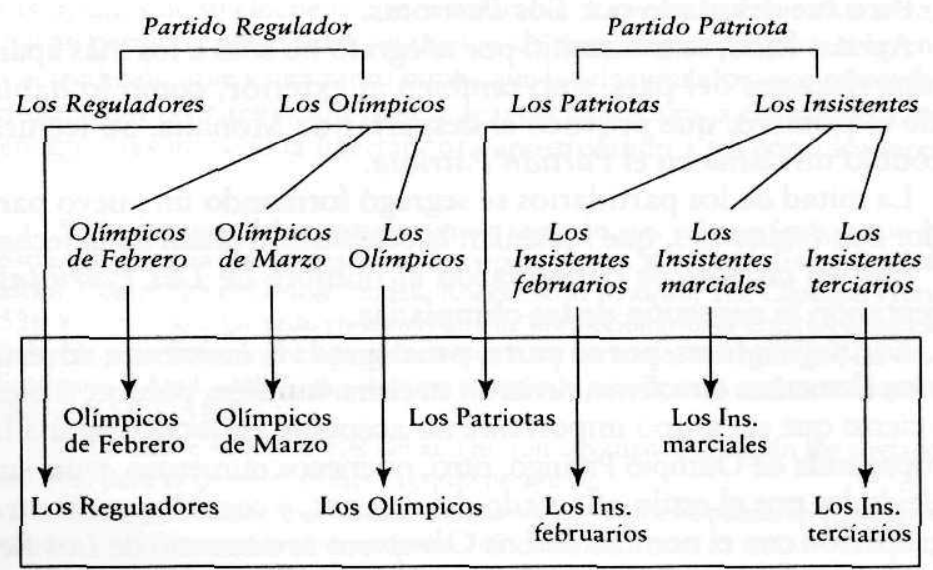




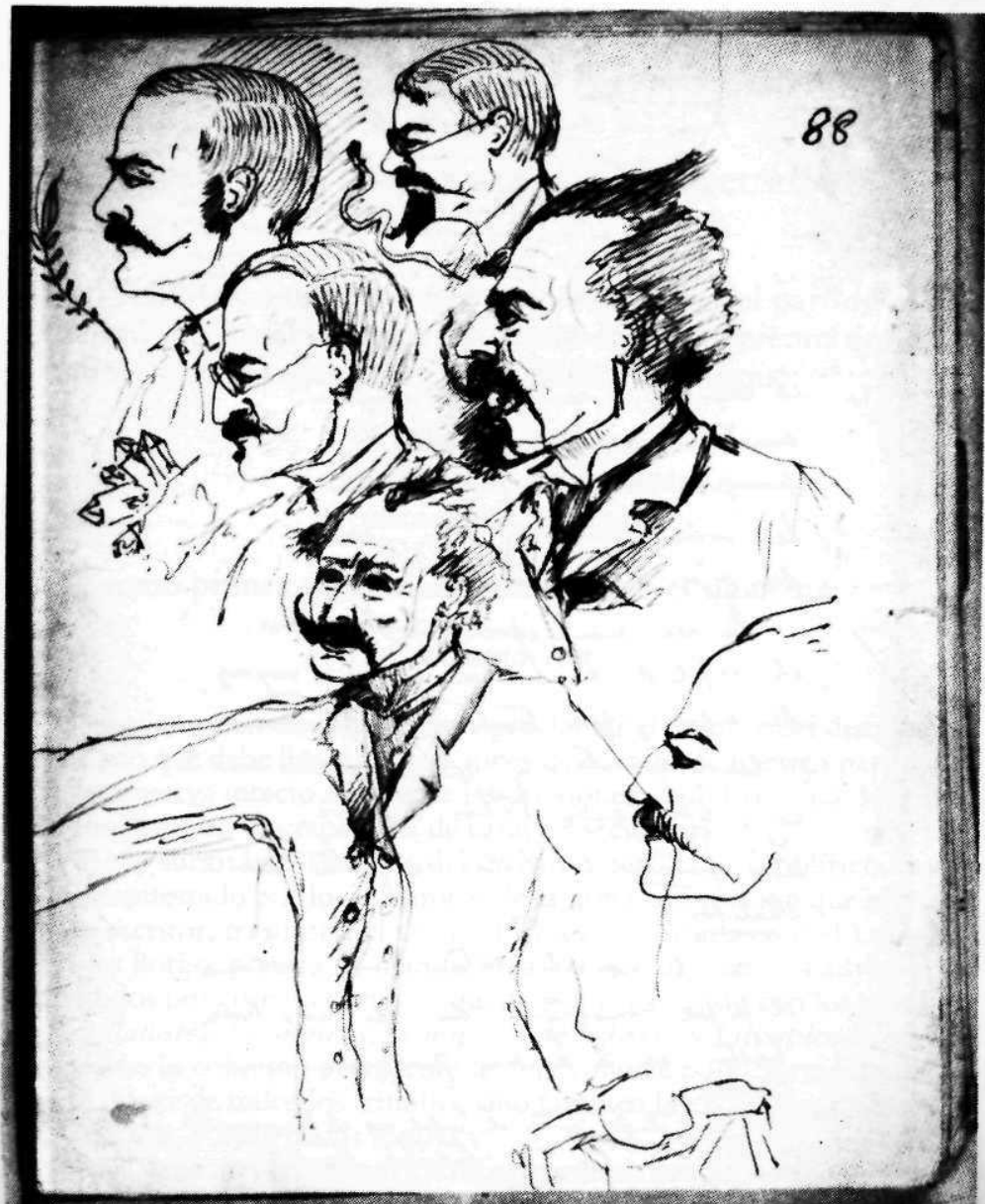

Dibujo intercalado en el manuscrito de Holmberg. 


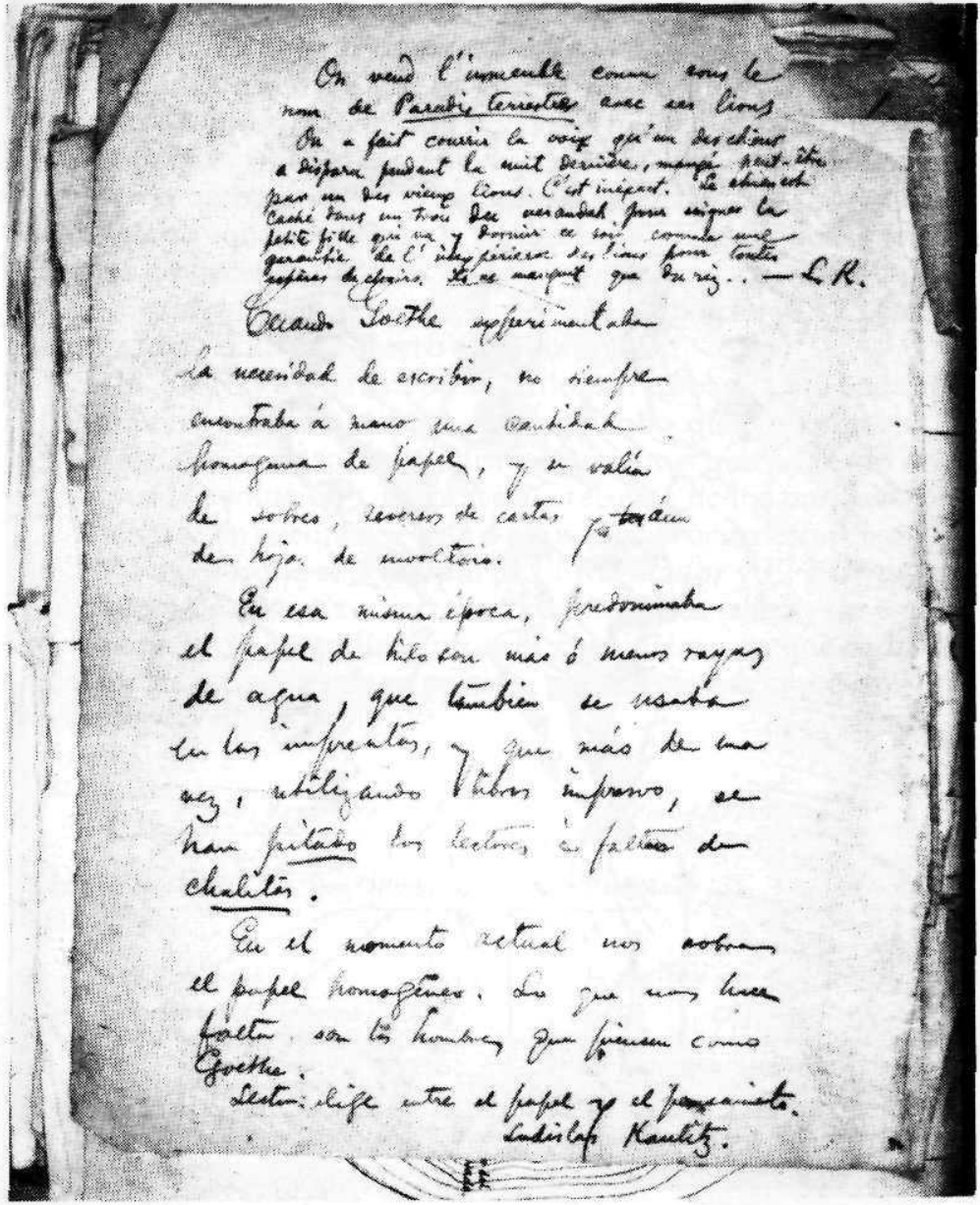

Reproducción facsimilar del manuscrito. 
Esta sinopsis demuestra cómo, llevados por su fervor patriótico, los monalitas habían formado ocho partidos políticos en tres días. Debe recordarse, sin embargo, que, a pesar de la subdivisión, los dos partidos fundamentales se mantuvieron cada uno con la idea generatriz: el Regulador que no reconocía la necesidad de vigorizar el patriotismo preexistente y el Patriota que sí.

\title{
IV
}

\section{EL PATRIOTA Y EL REGULADOR. - UN DOCUMENTO. - EUROPA ALBOROTADA}

El día 4 de Marzo de 1912, El Patriota, órgano del partido político del mismo nombre, colocaba como encabezamiento de su 1a. columna, y en grandes letras, las siguientes palabras:

\author{
Olimpio Pitango \\ candidato de los patriotas \\ para jefe del partido.
}

Y, como primer artículo de la redacción, el siguiente:

\section{Proclamación}

Cumplimos con un deber cívico: proclamar el nombre del distinguido ciudadano que debe llenar las funciones de Mentor de nuestro partido, el cual se conserva intacto a pesar de las divisiones y subdivisiones de la opinión fundadas en discrepancias de carácter secundario.

Pronto surgirán las luchas del civismo; pero el tino político tantas veces manifestado por los miembros de la noble agrupación que rodea al eximio escritor, trasunto fiel de las glorias conquistadas por el Legendario Gran Botijo, pondrá de manifiesto a los ojos de nuestros adversarios -divididos por cismas continuos que se han consagrado con los nombres de Reguladores, Olímpicos, Olímpicos de Febrero y Olimpicos de Mar$z o$ - cómo la cohesión persistente de una cohorte política representa no sólo la fuente de todos los triunfos, sino también la excelencia de las convicciones y la pureza de los ideales.

El día 9 del mes corriente, los representantes de todos los comités patrióticos, delegados para constituir el Comité Central, entregarán a la urna el voto imperativo y secreto de que son portadores, y ese día, 9 de Marzo, llegará a ser uno de los más gloriosos de nuestros fastos electorales, porque será el símbolo fiel del comicio moderno, el comicio libre, no contaminado por las impurezas de la coacción partidista arbitraria y des- 
considerada. Así votaban los próceres inmortales en los tiempos del Gran Botijo y de Cachimbo Pérez - lo que quizá está vedado comprobar a los jóvenes de la generación presente a causa de la desidia de un gobierno que no ha sabido reconocer la importancia que tenía el maravilloso archivo confiado a su impericia.

Macabeo

\section{Importante descubrimiento}

El distinguido paleógrafo Nango-Pichango, 33 al revisar algunos documentos de nuestro archivo nacional, ha descubierto, en uno de los legajos, una hoja intercalada y suelta que contiene indicaciones relativas a la existencia de una ruina al parecer de grande interés arqueológico. Nada más podemos anticipar al respecto a nuestros lectores, porque el feliz descubridor se ocupa, en estos momentos, en reconstruir las afirmaciones obliteradas...

\section{El Regulador}

El día 5 de Marzo, El Regulador, órgano del partido político del mismo nombre, encabezaba su 1a. columna con el acápite:

\section{Proclamación}

Nos es grato, gratísimo, comunicar a nuestros lectores que, con fecha de ayer, el distinguido colega de El Patriota proclama como candidato para jefe de su Partido al ilustre escritor Olimpio Pitango que ha sabido contagiar a sus compañeros de tal modo que, si no fuera porque el artículo está firmado Macabeo no tendríamos inconveniente en atribuirlo al mismo agraciado, tal es la identidad de la verba flexible, imaginativa, pintoresca e inventiva.

Contiene ese artículo una afirmación que adoptaremos y que se refiere al eximio escritor, trasunto fiel... del Gran Botijo... En efecto, algo de Botijo le hemos encontrado.

Lo que es una verdadera lástima es que un partido de principios como el Patriota se halle dividido por cismas continuos que se han consagrado con los nombres de Patriotas, Insistentes februarios, Insistentes marciales, e Insistentes terciarios.

Lamentamos también que Macabeo, un escritor sagaz y prudente, exalte tanto la importancia del 9 de Marzo, como día glorioso, porque esto nos Autor.

33 "Ñanga-pichanga equivale a la voz castellana mentirijillas." Nota del 
amenaza con la posibilidad de que llegue a consagrarse como un día más de fiesta. ¡Y qué será cuando los paleógrafos descubran o reconstruyan los discursos del Gran Botijo y las arengas de Cachimbo Pérez!

Por otra parte, el artículo contiene afirmaciones que nos auguran días estupendos para cuando lleguen a realizarse "comicios libres no contaminados por las impurezas de la coacción partidista, arbitraria y desconsiderada "-iy todo a base de voto imperativo! - Bienteveo.

\section{El Patriota}

El día 6 de Marzo contestó:

La ingenuidad de El Regulador es digna de sus cabezas dirigentes. En el periodismo de todo el mundo existen convencionalismos tácitos que forman parte de la liturgia efemeriodográfica del espíritu de cuerpo. Y aún suponiendo que el nombre de Macabeo fuese un pseudónimo, no veríamos en ello nada de particular.

\section{El Regulador de 7 de Marzo dice:}

Nosotros tendríamos el pudor de no designarnos a nosotros mismos como eximios, a menos que los convencionalismos litúrgicos del espíritu de cuerpo nos obligaran a tragarnos un Botijo, peor aún un Gran Botijo, y pésimo un Cachimbo de Pérez.

\section{El Patriota, de 8 de Marzo:}

En momentos en que la diatriba procura empañar la pureza de nuestras intenciones, aprovechando de paso la terminología de nuestras frases culminantes, nos es grato anunciar a los historiadores que acaba de descubrirse en una cripta secular un legajo que contiene tres arengas de Cachimbo Pérez. El ilustre paleógrafo que las reconstruye nos las ha ofrecido para engalanar nuestras columnas, lo que será para nosotros una satisfacción y una gloria.

\section{El Regulador, \\ 9 de Marzo:}

Hoy es día de gloria.

Los delegados de todos los comités del Partido Patriota celebrarán en el Comité Central del mismo un comicio puro y libérrimo depositando en la urna su voto imperativo. 


\author{
El Patriota, \\ 10 de Marzo: \\ "Jefe del Partido Patriota \\ Olimpio Pitango".
}

\title{
El Regulador, \\ 11 de Marzo. \\ Telegramas
}

París, Marzo 10.- Llegaron por telégrafo artículos de Olimpio Pitango. Estupefacción general respecto de próceres, reconstituciones, invenciones, Botijo, Cachimbo Pérez. Consultado paleógrafos, arqueólogos, pintores. Declaran está loco o fraguando una gran mistificación. Talento desviado. Hombre muy peligroso si consigue prestigio en Monalia Tupitambo.

\section{El Patriota, 12 de Marzo:}

Monalia, 11 de Marzo.- Bajo la presidencia del jefe del Partido Patriota se reunió el Comité Central del mismo y en virtud de los poderes de que han sido revestidos los delegados por los votos unánimes de todos los comités locales, resuelven invitar a los ciudadanos del país monalita para que se reúnan en comicios el día 15 de Mayo y procedan a elegir 30 ciudadanos aptos que redacten un proyecto de Constitución Nacional. - Los Secretarios.

\section{La Convención}

Hasta el momento parece que nuestros adversarios guiados por un espíritu vetusto habían echado a la broma los movimientos preparatorios de nuestro Partido para iniciar las reformas que la civilización moderna reclama en este país.

Se ha considerado como una locura el empeño de modificar las costumbres añejas dando a los pueblos de Monalia una Constitución a semejanza de las que rigen a nuestros vecinos continentales, tomando de modelo la de los Estados Unidos de Norte América.

Primero se burlaron del exotismo. Considerando que se trataba de algo sin fundamento se han burlado de todo. Y Monalia tendrá cámaras como poder legislativo, poder ejecutivo, poder judicial, comicios libres, archivos regulares, una historia, próceres, estatuas, himno y todo aquello que, en la sucesión de añejeces se consideraba ridículo y utópico.

En presencia de tales reformas ¿qué habremos perdido? La santa inocencia, la sublime felicidad de una ignorancia convencional, mientras se desenvolvian a la par todas las aptitudes del saber humano. 


\section{El Regulador, 15 de Marzo. Telegramas}

Londres, Marzo 14. (De nuestro corresponsal político).

Todos los diarios de esta capital comentan la situación de Monalia, y parece que están bien informados. El Times en particular, le dedica un largo artículo, del que transmito el párrafo más importante: Nunca hubiéramos pensado - dice- que un país tan tranquilo y tan juicioso diera de pronto un vuelco de carácter tan inesperado. No existe una sola enciclopedia, ni un solo tratado de geografía que no haga mención de ambas virtudes políticas... Las conferencias (lectures dice el original) han sido siempre allí formas de propaganda, y sus numerosos y hábiles conferenciantes, profesores en las instituciones de enseñanza superior, o especialistas en los variados objetos del saber humano, congregaban siempre un público selecto que difundía cada vez con mayor empeño la ilustración general. No se recuerda allí un solo descubrimiento realizado en cualquier parte del mundo y apenas recibida la comunicación telegráfica, que no fuera objeto de una conferencia pública o de excelentes artículos de su prensa ilustrada (learned), habiéndose presentado más de un caso en que se han realizado allí en el mismo día experimentos comunicados de otros países en la forma concisa telegráfica, mientras que algunas naciones que ocupan una categoría muy superior, los practicaron después... Desde hace pocos años algunos escritores europeos consideraron que la plaza (market) era buena... han conseguido exaltar con tanto fuego ciertas cabezas, en particular la del escritor Olimpio Pitango, que, como ha podido leerse en numerosos telegramas llegados de Monalia, se ha producido en ésta una verdadera efervescencia que no pueden contener los más prudentes y respetables ciudadanos. La obra de Olimpio Pitango parece una pesadilla, verdadera creación de un lunático, y en ciertas ocasiones de un loco de remate. Partiendo (starting) de ficciones absurdas ha llegado a convertirlas por una sugestión maravillosa en hechos que sus adherentes ya consideran probados por documentos irrefutables... y el incendio se propaga... Existe el peligro de que se extienda a las naciones continentales vecinas, y como es un solemne mentiroso, conviene que Inglaterra tome algunas medidas de precaución.

París, Marzo 14. - Del Fígaro: La fiebre de exotismo que ha estallado en Monalia tiene su apóstol en el más sublime claqueur ${ }^{34}$ que sea posi-

34 claqueur: persona pagada para que aplauda. 
ble imaginar. Ni el mismo Rabelais ${ }^{35}$ en los momentos más inspirados de su verba incomparable ha conseguido arrancar de sus lectores carcajadas más pantagruélicamente sonoras que las que despiertan la lectura de los largos telegramas que de allá nos envían. Parece imposible que una nación tan juiciosa se haya dejado sugestionar por Olimpio Pitango, cerebro digno de encerrarse en el cráneo de Don Quijote cuando le zumbaban al oído ráfagas de caballería. Jefe de un partido ya poderoso, parece que su apostolado resulta de la asiduidad con que acudía a escuchar las conferencias de algunos escritores europeos que han visitado Monalia desde algunos años a esta parte... Se teme una conflagración... Francia debe imitar a Inglaterra, en este caso particular, porque sus intereses pueden ser afectados por una propaganda tan perniciosa si llega a influenciar a las naciones continentales vecinas...

$$
* * *
$$

Berlin. Marzo 14. - El Ministro de Marina Contralmirante Von der Bum ha ordenado al Comandante del Donnerwetter ${ }^{36}$ que se estacione en aguas de Monalia.

$$
* * *
$$

Madrid. Marzo 14. - Si son ciertas las noticias que llegan de Monalia a esta corte, estamos de parabienes. El Consejo de Ministros, al tener conocimiento de lo que ocurría, se vio obligado a suspender la sesión después de la lectura de los artículos de Olimpio Pitango. S. M. el Rey, a causa de la risa se retiró a sus habitaciones con un calambre en el estómago que felizmente pasó breves momentos después. Aquí nadie toma a lo serio los movimientos de Monalia, pues los considera como uno de esos estallidos de patriotismo que más que a nada se parecen a una borrachera nacional, que sin duda pondrán a raya a los pensadores de una nación famosa por su juicio secular. Algunos eruditos opinan que presentan, en la psiquis de las masas, muchas analogías con las efervescencias populares que Zola describe en Naná, o con el furor de Las Cruzadas, de manera que el Jefe del partido exaltado, ya que no se llama Pedro, quedaría bien designado como Olimpio el Ermitaño... La Academia por su parte, ha dictaminado que las vocales sueltas no sean acentuadas, lo que representa una enorme economía de tinta.

$* * x$

35 Rabelais: (1495?-1553) humanista y escritor francés, autor de Gargantúa $y$ Pantagruel (1534?), obra monumental en la que a través del humor el autor expone sobre la paz, la educación, la felicidad.

36 Donnerwetter: (alemán) explosión. 
Viena. Marzo 14. - Dos famosos alienistas de nuestra Facultad han partido hoy para Génova donde tomarán el paquete que primero salga para Monalia.

$$
* * *
$$

Roma. Marzo 14. - El mejor de nuestros músicos se ocupa en estos momentos en orquestar el himno nacional de Monalia. El motivo es de una belleza indecible, y el conjunto, según se nos afirma, de una grandiosidad tal, que los monalitas se curarán homeopáticamente.

* * *

Nueva York. Marzo 14. - Hoy se ha embarcado una tonelada de píldoras de Bromhistoctono de Smith para Monalia.

$* * *$

Bruselas. Marzo 14. - Por el vapor Encaje sale hoy para Monalia un gran cargamento de cohetes voladores y fuegos de artificio.

$* * *$

\section{Marsella - Marzo 14. On vend. El Patriota, 16 de Marzo.}

\section{El triunfo póstumo}

Ocurre con frecuencia - que la verdad histórica - no pueda abrirse paso porque la ocultan sombras; - pero su vida es tanta, - si la sustentan glorias, - que resplandece al cabo - como brillante aureola.- La lápida que pesa, la lápida marmórea, - que cubre los despojos - del que alentaba otrora con la potencia mágica - de un Milón de Crotona, ${ }^{37}$ - de sutileza ogaño y abre su cuenca fosca. - Luce por fin el día - de las solemnes honras, - y un escultor divino, - de inspiración famosa, - con la mejor arcilla - que viene de la Europa - de nuestro Gran Botijo - plasma la ilustre forma. - La abovedada frente - donde el saber se aloja, - los ojos centelleantes - y la elocuente boca, - la diestra levantada - los pliegues de la ropa... - todo es verdad que vive ... - hasta en las mismas botas. - Pero la gran sorpresa -

${ }^{37}$ Milón de Crotona: (siglo vi a.C.) atleta griego que ganó seis veces los Juegos Olímpicos y Los Píticos, famoso por su fuerza, comandó la armada de su pueblo que venció al pueblo de Sibaris en el 511. 
para la turba tonta, - para los sabios necios - que la verdad ignoran, - será una noble estatua - que las musas coronan, - la de Cachimbo Pérez, prócer de las victorias! O.P.

\section{El Regulador, 17 de Marzo.}

Para muchos lectores de El Patriota ha pasado inadvertido un acontecimiento político literario de altísima importancia, debido sin duda a la manipulación tipográfica de uno de esos monumentos destinados a perdurar en la memoria de los pueblos. Olimpio Pitango nos ha ofrecido ayer un presente glorioso, ¡El Himno de Monalia! en heptasílabos vibrantes asonantados o sea, si se quiere, alejandrinos con la cesura del hemistiquio clásico.

Mientras llega la música que un ilustre compositor prepara, como lo anunciamos en nuestro número del 15 , puede cantarse con la de

Cuando Juana de Arco tocaba la corneta... ${ }^{38}$ las de

y lo que es más curioso, se le puede aplicar también, con bastante éxito,

Arrorró mi niño, arrorró mi amor ...

y de $E$ viva Garibaldi...39

Lo que se puede lamentar es la falta del coro.

\section{V}

CARÁCTER DEL PUEBLO. - CAUSAS DE SUPERIORIDAD.

- OLIMPIO PITANGO MINISTRO PLENIPOTENCIARIO EN SUD AMÉRICA CONTINENTAL

Para la generalidad de los lectores de El Regulador no había la menor duda de que Olimpio Pitango estaba loco; porque le constaba, como a la minoría, que Monalia como el resto del Continente, había sido poblada por aventureros audaces y valientes, de noble estirpe y ambición tanto más crecida cuanto mayor era el desamparo en que los habían dejado en su patria de origen las leyes del

38 Juana de Arco: (Domremy, Francia, 1412-1431) de gran misticismo. Apariciones de Santa Catalina y San Miguel la llevaron a intentar salvar Francia de la dominación inglesa. Dirigió el ejército que liberó Orleans y derrotó a los ingleses en Patay. Abandonada, cayó en poder de sus enemigos que la condenaron a morir en la hoguera. Fue canonizada en 1920.

39 Giuseppe Garibaldi: (1807-1882) patriota italiano que con sus conquistas de Sicilia y Nápoles (1860) contribuyó a la unidad italiana durante el reinado de Víctor Manuel II. En Sudamérica sirvió a los gobiernos de Brasil y Uruguay durante los años 1836-1848. 
mayorazgo. 40 Pero la riqueza del suelo, el clima delicioso, y el juicio de sus principales jefes, todo contribuyó a dulcificar su carácter sin aminorar sus bríos, cuando en sus prácticas fueron tan altos como los de Aragón y proclamando así los derechos del hombre 2 1/2 siglos antes que estallara la Revolución Francesa de 1789.41

Mientras la fiebre del oro dominaba al resto del mundo, los monalitas fueron atacados por la fiebre de la paz y del trabajo, y considerando el peligro a que se exponían ante sus mismos compatriotas del Continente y de la patria de origen si se descubría el oro en sus montañas resolvieron convertir en el más riguroso secreto el conocimiento de las localidades en que encontraran el codiciado metal.

Siendo común el peligro, fue común el temor, y de éste nacieron las precauciones. No existen crónicas ni leyendas que lo revelen; pero sí rumores vagos de que el solo hecho de encontrarse atacado de nostalgia uno de los monalitas fundadores daba origen a su desaparición misteriosa.

Abundaba el hierro: lo trabajaron en todas sus formas. Explotaron el carbón mineral, las maderas de sus bosques, cultivaron los campos. Los ganados pululaban por todas partes y procuraron adelantarse a su época haciendo de la instrucción pública la base de su libertad.

Felices y contentos, los monalitas no tuvieron dificultades políticas internas, y como las leyes que ellos se habían impuesto eran pocas, justas y claras, los cerebros, desde los tiempos de la colonización, se vieron libres de todas las penurias inherentes a la difícil aplicación de leyes innumerables, absurdas y oscuras, lo que les permitió aplicar sus aptitudes intelectuales a otros fines útiles y prácticos.

No descuidaron, sin embargo, la defensa nacional; y como la naturaleza del clima no era deprimente, educaron, a la vez que las aptitudes mentales, las energías físicas.

40 mayorazgo: el mayorazgo se origina en la Edad Media española y consistía en la separación de ciertos bienes del patrimonio familiar (unidad que tenía un orden sucesorio especial basado en la primogenitura) con el fin de que dichos bienes permanecieran en la familia. El mayorazgo fue abolido por la ley 1820 , en 1841 , como consecuencia de las contradicciones en que caía, y por resultar incompatible con el individualismo moderno (Germán Bleiberg, Diccionario de Historia de Espana, 3 vols. [Madrid, Alianza Editorial, 1986] 2: 979-980).

${ }^{41}$ Revolución Francesa: (1789) surgió para destituir los privilegios de la aristocracia y el alto clero y establecer una sociedad igualitaria, donde los ciudadanos pudieran participar en el gobierno y en los cargos públicos. El 4 de agosto la Asamblea Nacional proclamó la Declaración de los Derechos del Hombre. 
Mientras que en la capital de un país del continente vecino, destinada a ocupar tres siglos después uno de los primeros rangos, se presentaba al Cabildo, a principios del siglo XVII, un buen ciudadano, solicitando permiso para enseñar a leer y escribir a algunos niños, como que no había escuelas, y el Cabildo se lo concedía autorizándolo a cobrar a cada uno y por año dos reales de vellón por la lectura y dos por la escritura, importe que podía abonarse también en especies, Monalia estaba llena de escuelas de todo género, desde la primaria, hasta los institutos más adelantados de acuerdo con los conocimientos positivos de la época.

Conviene establecer aquí un fundamento muy curioso que explica por qué motivo pudo conservar Monalia durante tanto tiempo su unidad política, su tranquilidad interna, su gobierno patriarcal y la gran aptitud de progreso, ventajas que le atrajeron el respeto y consideración de las naciones, aun en épocas de relativa dureza bárbara.

No enseñaba el que quería sino el que podía.

Y para poder enseñar era necesario ser apto.

Esta aptitud no surgía de certámenes, ni de exámenes, ni de títulos, ni de recomendaciones sino del conocimiento que se tenía de las personas.

Las únicas entidades metafísicas superiores de carácter moral que enseñaban los monalitas eran la Verdad y la Justicia, que procuraban explicar a los niños en todas las formas concretas posibles. No les definían la Verdad diciendo que es lo que es, sino que les presentaban los hechos, las cosas, demostrándoles que tal cosa, una piedra, por ejemplo, era una piedra; que tal otra era una mosca; que la mosca no era una piedra y ésta no era una mosca. (A su paso por Monalia en viaje al Continente, Pero Grullo 42 casi se muere de vergüenza al visitar una escuela primaria.) Este sistema, que la Pedagogía moderna ha bautizado con el nombre de método intuitivo, no tenía nombre en Monalia; no tenía sino existencia. Para enseñar a los niños por tal sistema, no era necesario que aprendieran a leer ni escribir, bastaba que conocieran muchos hechos, muchas cosas, y como retenían los nombres, se fortificaba de paso la memoria. Cuando llegaban a la edad apropiada con el cerebro fortificado por el conocimiento real de las cosas y desarrollada la aptitud de distinguir las semejanzas que las aproximan y las diferencias que las se-

42 "Pero Grullo" (Perogrullo): supuesto personaje al que se atribuyen humorísticamente las sentencias o afirmaciones de contenido sabido y natural. 
paran, entonces los obligaban a representarlas. Un grado más adelante aprendían a leer y escribir, y solamente cuando estaban dotados de uso sensato de la razón, les definían la Verdad diciéndoles, "la Verdad es una condición esencial de la existencia de las cosas y de sus relaciones"; pero se comprende que lo explicaban con otras palabras; - lo importante era que lo entendiesen. Más tarde podrían asimilarlo o rebatirlo. Respecto de la Justicia el procedimiento era análogo.

De este modo nadie se daba importancia, ninguno se consideraba superior a los demás, desde el momento que las cosas se encontraban al alcance de todo el mundo, y el combinarlas de distinta suerte no era más que una propiedad que residía en ellas, y así esa combinación, ese resultado, era también una verdad, una condición esencial de las aptitudes de las cosas —el combinarse, el relacionarse entre sí.

Por eso los monalitas jamás reconocieron el derecho de invención, ni menos la patente de la misma. Entre ellos hubo siempre especialistas para todo, pero no los consideraban seres excepcionales, ni gloriosos, ni únicos. Se les designaba como aptos. Y habían llegado a un concepto tan bien definido de la aptitud, que habrían declarado loco, mal patriota y caduco al gobierno que hubiese recomendado para dirigir las maniobras militares a un monalita entendido en la fabricación de vidrio solamente $\mathrm{o}$ a otro reconocido apto en la confección de versos líricos.

Y es necesario decirlo alguna vez: los monalitas eran adiestrados en los ejercicios militares desde la edad de 3 años. A los 5 ya eran aptos para todos los movimientos de compañía; a los 15 para los de división, y como a esta edad ya manejaban todas las armas, se encontraban aptos para la defensa nacional.

Habituados desde sus orígenes a la selección de las aptitudes, el ser apto para pintar un cuadro, dirigir una maniobra, descubrir un astro, hacer una estatua, inventar una máquina, no tenía nada de particular. Eso no creaba distinciones especiales, no era mérito ninguno, porque todo había consistido en hacer lo que cualquiera: tomar las cosas existentes y relacionarlas. El mérito correspondía a la patria misma, a la nación que había sabido llevar de la mano a sus hijos por el camino que más le convenía.

¿Humos de raza? ¡Bah! Los fundadores eran españoles de nacionalidad; pero eso no implicaba una raza. Entre ellos habían llegado vascos, gallegos, navarros, catalanes, valencianos, andaluces, castellanos, murcianos, canarios... tenían por lo tanto sangre de 
celtas, de íberos, de godos (alemanes), de judíos, de árabes, de franceses, de italianos, de mauritanos, de eslavos, ... y los vascos, quién sabe de dónde - eran rojos-y según Basaldúa, 43 habitantes de un continente sumergido, de una raza antiquísima como los atlantes. ${ }^{44}$ ¿Humos de apellido? La primera precaución que tomaron los primitivos organizadores fue el cambio de los apellidos, de modo que al colonizar Monalia rompieron de un golpe toda tradición de familia.

El único humo al que se reconoció algún valor fue al humo del patriotismo.

Con tales antecedentes ¿de dónde sacaba Olimpio Pitango próceres, ni oradores, ni Pericles, ni Cachimbo Pérez, ni Botijos, ni Murillos, ni Rembrandts?

Imponiéndose a sí mismo tantas existencias ficticias como realidades históricas, iniciaba con la fantasía una verdadera revolución, y una revolución de mal carácter, porque iba a privar a la nación de todos los más grandes beneficios a que es posible aspirar: la paz, el orden, la libertad, la justicia, el bienestar, la felicidad, el respeto de las naciones, el ejercicio natural de las aptitudes, el desenvolvimiento de una democracia bien entendida, ¿para darle qué? ¿Una centralización absoluta de poderes que funcionaban admirablemente difundidos en pueblos animados por el sentimiento profundo de la patria? ¿Para qué? ¿Para imitar a otras naciones vecinas que tenían la clase de dirección constitucional que él proponía y que después de un régimen colonial absurdo y tiránico habían llegado a la más desastrosa anarquía militar, continuada por una anarquía política más desastrosa aún que había exigido imperiosa-

43 Pedro Basaldúa: periodista español (1906-?, Baracaldo, Vizcaya). Desde 1942 residió en la Argentina colaborando en las publicaciones vascas. Autor de: Con los alemanes en París, En España salió el sol (Diego A. Santillana, Gran Enciclopedia Argentina, 8 vols. [Bs. As., Ediar Soc. Anón. Editores, 1956-1963] I: 411).

44 atlantes: está aludiendo a Atlántida, continente legendario sumergido en el océano por un cataclismo que, según Platón, se extendía al occidente del estrecho de Gibraltar. Después del Renacimiento se intentó racionalizar el mito de Atlántida. Para algunos etnólogos, sus habitantes, los atlantes, eran los ascendientes de los guanches, vascos y antiguos italianos. Todavía en los siglos XVII y XVIII se debatía seriamente la credibilidad de la leyenda, y algunos hombres de letras como Montaigne, Buffon y Voltaire, la admitían (E. B. 2: 698). El tema de los orígenes de los vascos vuelve a ser retomado en el siglo XIX, con los estudios filológicos y lingüísticos. Lily Litvak menciona entre la extensa bibliografía al respecto un artículo, "La Atiántida y el pueblo basco" Euskal-Errial, 47, agos. 30, 1902, que supone a los vascos integrantes del continente perdido (El sendero del tigre. Exotismo en la literatura española de finales del siglo XIX (1880-1913) [Madrid, Taurus, 1986] 41). 
mente en una de ellas la creación de una ley por la cual el voto era obligatorio, mientras que en Monalia el voto por tradición y de hecho era un derecho y un deber, que nadie habría conculcado jamás ni en sueños?

Olimpio Pitango estaba loco, y loco de remate y lo peor es que había conseguido enloquecer de un modo ostensible a media nación.

Si su palabra aparecía fogosa y ardiente en sus últimos escritos, más ardiente y más fogosa se presentaba en sus arengas, a tal extremo que al escuchar una de ellas un monalita que había visitado las naciones vecinas del Continente llevando a Monalia una colección de dichos, refranes y metáforas exclamó entusiasmado: — “iAl lado de Olimpio Pitango, Cachimbo Pérez es un poroto!”- ¿Es decir que para ese monalita viajero Cachimbo Pérez tenía también existencia real y comparable?

¡Qué subversión!

¡Qué contrasentido!

¿Qué desastre!

Reuniéronse los miembros del gobierno patriarcal y resolvieron ... no ... el caso fue discutido primero, y en el curso de las discusiones no faltó quien propusiera encerrar a Olimpio Pitango en el Manicomio Tarpeyo. Pero una proposición semejante no era justa. ¿Dónde se encerrarían los innumerables oradores que habían surgido en los banquetes del 29 de febrero? ¿Allí también?

¿Eliminarlo? Tanto valía.

Resolvieron entonces celebrar con él una entrevista; Pitango acudió a ella.

- Por vez primera, ilustre Pitango - le dijo el más diplomático de todos los miembros del gobierno- corre peligro la nacionalidad monalita. Alemania ha ordenado al Comandante del Donnerwetter que se estacione en aguas de Monalia, y ha llegado esta mañana. Según telegrama de Río, Inglaterra ordena a la escuadrilla del Atlántico Sur que se presente en la Bahía del Progreso; Francia nos envía dos acorazados ... y esto va a seguir. El único ciudadano más apto para conjurar el peligro que nos amenaza, eres tú. Es necesario que ordenes al Partido Patriota suspenda todos sus proyectos políticos por algún tiempo. Esto no implica en forma alguna el desconocimiento de tus derechos: como ciudadano has conseguido crear un partido politico poderoso, bien venido sea; pero, cuando la patria corre peligro, los partidos políticos no existen, no hay más que uno: el de la Nación. Los miembros del gobierno aquí reunidos hemos resuelto confiarte 
una misión diplomática ante las naciones Sud Americanas. Tus despachos están prontos y firmados; indícanos los nombres de los ciudadanos que deseas te acompañen para extenderles sus nombramientos; ponte al habla con los personajes del Partido Patriota; recomienda a todos la mayor prudencia, y mañana a medio día, en una de nuestras naves, te embarcarás para Montevideo. Una vez allí darás cumplimiento a las instrucciones a que debes sujetarte después de abrir el pliego secreto que las encierra. Aquí tienes el que te acredita como Ministro Plenipotenciario de la Nación Monálica. ¿Querías próceres? Cumple como corresponde a tu energía, a tu talento y a tu patriotismo lo que se te ordena, y serás uno de ellos.

Olimpio Pitango se quedó mudo de asombro.

Saludó y se fue, pero murmurando: — ¿Qué lástima! ¡qué retardo! ¡cuánto tiempo perdido!

Ahora, ciudadanos - dijo el que había hablado—, sólo nos resta esperar que lo enchalequen en alguna de las naciones Sud Americanas.

- ¿Y cuál de ellas se atrevería a hacerlo?

-Cualquiera.

-Pero eso no es creíble. Los discursos y escritos de Olimpio Pitango son un contrasentido en Monalia; pero en las otras naciones Sud Americanas no. Casi todas tienen sus próceres verdaderos, sus eximios oradores, sus archivos, sus artistas; tienen un régimen de gobierno unitario o federal, constitución, cámaras, tribunales de todo género, historia, revoluciones por centenares, elocuencia a chorros en las arengas y en la prensa; en una palabra, tienen todo lo que le hace falta a Pitango para desahogarse, y cuando se encuentre en presencia de los oradores y escritores de esos países, entonces comenzará a apagar sus fuegos y se curará, porque ellos hablan como él, y hasta con mayor vehemencia, como que no mienten.

$$
* * *
$$

Tres días después llegaron a Monalia los diarios de Montevideo.

Abril 2. - Con todos los honores debidos a su rango fue recibido ayer por nuestro Gobierno el Ministro Plenipotenciario de la Nación Monálica, Exmo. Señor Dr. Olimpio Pitango. Ha sido muy agasajado en diversos círculos y como goza de gran fama de orador, no ha fallado quien, con mañas muy finas, lo hiciese hablar. Reservamos nuestro juicio, lo mismo que ha hecho él.

A los quince días llegaron diarios de Buenos Aires.

Abril 17. - Ha sido recibido por nuestro gobierno, y con los honores debidos a su rango, el Exmo. Señor Ministro Plenipotenciario de Monalia, 
ciudadano Olimpio Pitango. Como era de esperar, nuestros círculos sociales lo han colmado de agasajos, los fotógrafos lo han asediado, le han remitido centenares de tarjetas postales pidiéndole un pensamiento autógrafo y no podemos resistir a la tentación un tanto indiscreta de consignar aquí uno de ellos:

Tú debes ser mi ángel, dulce criatura cuando así manifiestas, lo que has pensado; yo soy un fuego fatuo, y en tu dulzura me has dado cuerpo y alma, que me han faltado.

Debemos advertir que, en su carta de remisión la señorita que solicitaba el autógrafo, se dirigía al Hércules de la oratoria monalita, tan grande como el enorme pensamiento que encierra. En uno de nuestros salones, otra le presentó el álbum con igual pedido. Lo revisó el ilustre jurisconsulto, tomando una pluma, escribió:
Me pides un pensamiento
que en este álbum quede fijo;
pero si no soy prolijo
se lo va a llevar el viento;
inspírame con tu acento
con el brillo de tus ojos, con esos suaves sonrojos, que de la luz son la gloria y si queda en tu memoria míos serán los despojos.

\section{O. Pitango}

Esta décima fue muy celebrada, no sólo por la galanura de los conceptos - bien merecidos por otra parte-cuanto por la rapidez con que se improvisó, Y porque tales cosas se elogian siempre.

$$
* * *
$$

Al leer estas noticias, el Gobierno patriarcal de Monalia y los miembros del Partido Regulador dijeron: - "Más vale así. Nuestro Ministro tiene más juicio en sus versos que en sus arengas y artículos políticos".

$$
* * *
$$

Buenos Aires, Abril 1912. - Todos los periódicos ilustrados de esta Capital nos ofrecen el retrato o la caricatura del Ministro Plenipotenciario de Monalia. Es muy culto; pero, según parece, no le han hecho gracia. En 
cambio ha quedado muy complacido con los retratos. Conociéndole sus recentísimas afecciones, ha sido muy solicitado por los coleccionistas de estampillas postales.

Ayer fue invitado a asistir a las declaraciones de un comité político. $\mathrm{Si}$ no fuera que hemos seguido con interés todo lo que El Patriota y El Regulador de Monalia han publicado desde su fundación, habríamos tenido una sorpresa colosal. Olimpio Pitango es de una altura que pasa de la mediana, delgado, figura arrogante, no representa 35 años, mirada viva, penetrante, bigote negro de buenas guías, magníficos dientes, modales de alta cultura $-\mathrm{y}$ las muchachas dicen que es un buen mozo.

$\mathrm{Al}$ arengar se transforma; se le inyectan los ojos, una de las guías del bigote se le va para arriba, la otra para abajo, en el período siguiente alternan, las mejillas se le incendian alternativamente también, todo lo cual es de un efecto diabólico y fantástico. Su voz es poderosa, vibrante; la dicción fácil y en extremo apasionada. Al exponer lo que constituye la posesión de un pueblo, es metódico, lógico; de pronto se exalta, imagina lo que un historiador tiene el derecho de reclamar porque no se tiene ni se ha tenido; sube el tono, vibra, tiembla - ya no es el historiador, es él quien exige. Entonces aparece Cachimbo Pérez, el Gran Botijo, Pericles y una multitud de personajes imaginarios. Es tal la realidad de la ficción, de la potencia imaginativa, que uno se queda sin saber qué pensar, y es mejor que no piense.

$$
* * *
$$

Al leer estas noticias, el Gobierno patriarcal de Monalia y los miembros del Partido Regulador dijeron... bueno, dijeron algo en primera de plural, dijeron: - Ya la... la... embarramos. Aun fuera de agua nuestro Ministro carece de juicio en sus arengas.

Le enviaron un telegrama cifrado y una gran cantidad de estampillas postales usadas y nuevas para responder personalmente a los innumerables cambios que le proponían.

Desde ese día, Olimpio Pitango se dedicó verdaderamente con pasión a las estampillas y a la señorita del álbum.

— ¡Ojalá! —dijeron en Monalia.

Antes de cumplirse medio año de ausencia, Olimpio presentó un ultimatum a la señorita del álbum, la cual le contestó secamente:

-Agradezco mucho el honor que Ud. me dispensa; pero antes de contestarle de un modo definitivo, deberé exigirle un juramento solemne de que jamás, mientras yo viva, volverá Ud. a Monalia.

Al oír estas palabras, Pitango murmuró “¡Espía!”, se paseó a grandes trancos por el salón - y repetía entre dientes: "Botijo... Cachimbo Pérez... los archivos... Pericles... Tipitamba... Sichinta... Sambomba... 
- Dentro de la solidaridad internacional de los pueblos, Señor Ministro, disminuyen, por su gran número, las glorias de los próceres locales, y si Ud. no lo toma como una ofensa, le diré que, al lado de Napoleón, ${ }^{45}$ de Aníbal ${ }^{46}$ y de Alejandro, ${ }^{47}$ Cachimbo Pérez es un poroto.

- La patria, para un monalita, es el primero, el más grande y el último de los amores... - y paseándose otra vez... - Aníbal... Botijo... Sambomba... Cachimbo... ¡no! Déjeme Ud. pensarlo durante un mes.

Al día siguiente, recibió Pitango un extenso manuscrito procedente de Monalia. Era del Comité Central y contenía graves cargos al Jefe del Partido. Casi, casi, aparecía más de una vez la palabra "tránsfuga".

Su situación era terrible.

CLAUDIO MOLOSO. - EL GOBIERNO. - EL PLEBISCITO.

- EL GABINETE NACIONAL

A pocos kilómetros de distancia de las cataratas y sobre una meseta que es como la continuación del penúltimo contrafuerte de los mayores situados antes de llegar a aquéllas, existen algunas construcciones rurales en campo descubierto, pero rodeado de espesos bosques, menos al norte. Es la estancia de Claudio Moloso, viejo setentón de larga cabellera blanca y barba de nieve. Ágil como buen montañés y fornido como un verdadero moloso, es un hacendado tan inquieto de cuerpo como sereno en el pensar y en el consejo. El mes de Mayo es bastante crudo en las alturas en que habita; pero

45 Napoleón I: (1769-1821) emperador de Francia, contrajo matrimonio con María Luisa de Habsburgo. Dueño del poder por sus victorias militares con Italia, Egipto, Jlevó a cabo una gran obra gubernamental y legislativa: Banco de Francia, Legión de Honor, Universidad, Código Civil. Después de una larga guerra con otros países, fue derrotado en Leipzig (1813). Fue desterrado en la Isla de Santa Elena, después de la derrota en Waterloo.

46 Anibal: (247-183 a.C.) guerrero cartaginés hijo de Amílcar, dominó buena parte de la península ibérica, atravesó los Pirineos, traspasó los Alpes y venció a los romanos en varias batallas. Fue derrotado en Zama (202 a.C.) por Escipión el Africano.

47 Alejandro Magno: (356-323 a. C.) rey de Macedonia, hijo de Filipo y Olimpias. Creador del gran imperio griego que se extendía por el este, hasta la India, por el norte, hasta Escitia y por el sur, hasta Egipto y el golfo Pérsico. A él se debe la propagación del helenismo en Asia y África (E. B. 1: 571). 
se pasea en el borde de la meseta esperando a alguien, porque le han hecho telegrama de la estación más próxima del ferrocarril. Nada le costaría montar a caballo y galopar unas 4 o 5 leguas hacia el nordeste; mas como no lo han llamado, espera. Una hora después divisa tres jinetes que se acercan y es más que probable que sean ellos los que han llegado en el tren de la Capital y vienen a buscarlo. Diez minutos después le estrechan con afecto la mano tres ciudadanos que forman parte del Gobierno. Monta a caballo también, pues tiene el suyo allí cerca, y siempre echarán media hora en llegar a las casas. de los tres.

-El gobierno reclama tu opinión, Moloso — dijo el más viejo

- Lo imaginaba, porque como el tiempo está bravo, no es el más a propósito para visitar a la gente de las montañas.

-Así es. Hemos pensado que tu presencia en la Capital es necesaria. Este alboroto producido por Olimpio Pitango nos tiene muy preocupados.

- ¿Por qué?

- Porque es más serio de lo que pensábamos al principio. serio.

-Pues yo creía que desde el principio lo habían tomado a lo

- ¿Lo has seguido?

- En todo y por todo. La arenga pronunciada en Buenos Aires no volvió a repetirse, lo que me hizo pensar que Uds. le ordenarían que se dejase de arengas.

-En efecto, así fue.

-Pero - continuó Moloso-, su ausencia nada significa, porque la juventud y los papa-moscas se han alborotado. Convencidos, como lo está él, de la existencia de los próceres, de Botijo y de Cachimbo Pérez y de las necesidades políticas de la Nación, ya es imposible apagar el incendio.

-Esa es nuestra opinión también. Aunque nos han asegurado que su presencia no es una manifestación hostil en las aguas del golfo, hay allí cinco barcos de guerra, uno de Alemania, uno francés y tres ingleses. Los Ministros de Alemania, de Francia y de Inglaterra se interesan por estos asuntos tanto como nosotros.

-Y piensan -interrumpió Moloso- que no tienen remedio y que lo único que se puede hacer es encauzar el desborde.

- Lo has dicho.

-Claro está. Bueno, bueno. Y no hay qué hacerle. Así he pensado yo también desde el primer día. Bastantes ganas tuve, cuando 
leí el primer artículo descabellado pero incendiario de Olimpio, de traérmelo por estas montañas, y hacerlo tomar un baño de aguas arriba de las cataratas. Estos baños son muy eficaces, porque a cualquiera le pasa un accidente. Se acabó Monalia por ahora. Pero vamos llegando y conversaremos después de almorzar.

Apenas instalados y una vez realizadas algunas ligeras prescripciones higiénicas, almorzaron tan alegremente como era posible, hecho lo cual, rodearon una chimenea alimentada con trozos de madera dura y carbón, y continuaron su plática.

- Ante todo - dijo Moloso- es necesario procurar que esos buques se retiren de nuestras aguas. Cuando los pueblos pacíficos $\mathrm{y}$ tranquilos se alborotan son peores que los pendencieros, y bajo la influencia de los demagogos exaltados son capaces de llevar a cabo las mayores atrocidades. Conviene entonces que no tengan motivo de encono por la presencia de esos buques. Pero ... ¿̇supongo que pasarán Uds. la noche aquí?

-De ningún modo. A las 5 de la tarde pasa un tren que nos llevará esta noche a la Capital.

-En tal caso, conviene que nos pongamos en marcha ahora mismo.

\section{Dicho y hecho.}

Pasadas las 10 de la noche, llegaron a Molenia y media hora después se reunían los miembros del gobierno, cuyo jefe era Moloso, a quien invitaron a tomar la palabra.

- Estoy al corriente -dijo- de todo lo que pasa, y lo he meditado con toda prudencia. Opino que lo primero que debemos hacer es pedir a los Ministros europeos que retiren a otras aguas las naves de sus respectivos países. Es posible que sus instrucciones les permitan proceder en el acto; en caso contrario, el telégrafo resolverá el punto. Para contener este fatal movimiento subversivo sólo habría un remedio: la dictadura o la ley marcial. Una u otra pueden tener éxito tratándose de cuerdos exaltados; pero serían ineficaces tratándose de locos que se alborotan por las fantasías de un lunático y consiguen edificar sobre arena y que el castillo no se les derrumbe. ¿Qué podemos hacer entonces? Seguir el movimiento. ¿Han convocado a elecciones para crear una Convención? Convoquemos a los pueblos para que determinen primero por un plebiscito si la quieren o no. ¿La quieren? Bueno. La Nación, al fin, pertenece a sus ciudadanos. Pero es que quieren tener un día patrio, y esto sólo ha dado origen a dos partidos políticos de los que, con pocas excepciones, forma parte toda la población. Olimpio Pitango, inesperadamente discreto en ese caso particu- 
lar, indicó que ese día sería designado por las Cámaras; pero esto solo ya envolvía como hechos consumados, la afirmación de la existencia de una Convención, de Cámaras y de todos los resortes de un Gobierno Constitucional. Los demagogos exaltados, más locos que su jefe, sostienen que debe mantenerse ardiente el patriotismo, y todo junto ha dado como consecuencia la formación de ocho partidos políticos. ¿Qué será cuando al discutir la constitución del estado se trate de las diversas formas de gobierno: Monárquica o Republicana, y suponiendo, sin tocar a ésta, que llegaran a adoptar la primera, se formarían partidos por la monarquía absoluta o constitucional, y éstas a su vez darían origen a las formas hereditaria o electiva, y así en lo demás? Vendrían luego los asuntos religiosos, porque estos locos de Monalia, por espíritu de imitación, van a convertirse en creyentes y a dividir sus opiniones entre todas las sectas, $y$ antes de un año tendremos más de 500 partidos políticos y religiosos. Sigamos entretanto la corriente. Veamos mañana a los ministros extranjeros; sus intenciones son buenas, y retirarán las naves. Enseguida vendrá el plebiscito.

- Has hablado como siempre, Moloso y haremos lo posible para que seas nombrado Presidente de la Convención primero, de la Cámara de Diputados después, y por último de la República.

-Y si llega el caso de que asuma la Dictadura, no será difícil que las cataratas nos causen algunas sorpresas -agregó el ciudadano que primero había hablado en la hacienda de Moloso.

-Dejemos actuar al tiempo — dijo Moloso.

$* * *$

Molenia, Mayo 15 de 1912

El Gobierno Central de Monalia:

Considerando:

Que los últimos acontecimientos ocurridos en la Nación, cualesquiera que sean sus causas y consecuencias representan un derecho inalienable de la misma;

que la existencia de los partidos políticos constituye una fuente de equilibrio para el mejor gobierno por cuanto ella garantiza la mayor seriedad en el estudio de todas las cuestiones que puedan relacionarse con el desenvolvimiento nacional y con el bienestar de los ciudadanos;

que la convocatoria a elecciones de convencionales para proyectar una Constitución Nacional no se encuadra en las funciones de los partidos políticos sino en las del Gobierno Central; 


\section{Decreta:}

Art. 1. Convócase a todos los ciudadanos de Monalia a un plebiscito para que declaren, el día 1o de Junio del año corriente 1912 si quieren o no quieren que se reúna una Convención Nacional Constituyente.

Art. 2. Hágase saber a todos los pueblos en la forma habitual, y también el procedimiento.

El Gobierno Central

Por más esfuerzos que hicieron algunos demagogos exaltados para desvirtuar los términos del Decreto anterior, no tanto por espíritu de oposición cuanto por hacerse ostensibles, no les hizo caso el pueblo, y así desaparecieron las dificultades que podrían haber surgido de la existencia de los ocho partidos políticos de creación reciente, y dejando de lado todas las desavenencias, recibió el Decreto con el mayor entusiasmo, al que contribuyó no poco la noticia de que los buques europeos de guerra, estacionados en el Golfo, levarían anclas al día siguiente y se despedirían de Monalia en forma estruendosa.

Molenia estuvo de fiesta.

Desde la mañana del 16 de Mayo aparecieron empavesadas todas las naves surtas en el puerto, y muy particularmente las cinco europeas de guerra, cuyos comandantes, al visitar a los miembros del Gobierno Central declararon que se despedían de la $\mathrm{Na}$ ción Monálica con verdadero sentimiento, porque un pueblo que tenía un Gobierno semejante estaba llamado a grandes destinos; que era un gran pueblo; y que confiaban en que la fiebre política despertada por Olimpio Pitango resultaría un motivo más para consolidar las prácticas institucionales, aunque muchos ciudadanos se empeñaran en tener una Constitución escrita, con todas las creaciones políticas inherentes a las reformas presuntas, habiendo exteriorizado aquella fiebre, por otra parte, la enorme importancia de las energías vitales de la Nación.

Una vez que estuvieron embarcados, tronaron los cañones; contestóles la batería de las salvas; el pueblo saludó con casi todos los cohetes voladores y bombas que habían llegado de Bélgica, y se alejaron de la Capital con todas las banderas y gallardetes flameando al soplo del viento marino. A la noche hubo fuegos artificiales pero la verdadera pirotecnia se reconcentró en la sala de Acuerdos del Gobierno, donde los miembros de éste conversaron largamente sobre un hecho interesante que todos habían observado, y era que, desde que se establecieron en el Golfo, hasta perderse de vista al retirarse, todos los jefes y oficiales de las cinco naves no 
se habían desprendido de sus binóculos para examinar la serie de baterías que adornaban las costas de aquél y los conciliábulos que celebraban sobre cubierta con gestos de sorpresa.

-Y pensar que los oficiales de esas naves pertenecen a las tres potencias que más millones gastan en el espionaje militar y político - dijo uno de los Ministros.

-No seas imprudente - agregó Moloso-, no olvides que Monalia es la Nación que posee más secretos políticos y militares inviolables.

Como el día del plebiscito se acercaba y algunos creían que su ejecución ofrecería dificultades por ser un hecho tan nuevo en la vida monálica, el Gobierno Central demostró prácticamente que no existía operación más simple.

Se habló de un censo de la población.

Era inútil.

El Censo estaba hecho ya y de un modo que no daría lugar a equivocaciones. Desde el momento que el deber patriótico del ciudadano le imponía desde los quince años el servicio militar en defensa de la patria, tenía el deber, patriótico también, de dar su voto en todas las elecciones o actos semejantes, y desde aquella edad se sentía más orgulloso de tal deber que de tal derecho.

El Gobierno hizo una convocatoria militar por la cual todos los electores, es decir, todos los ciudadanos desde la edad de 15 años se presentarían en sus respectivos distritos, sin armas, naturalmente, formando el $1^{\circ}$ de Junio a medio día.

Como cada provincia era a la vez una circunscripción militar, el jefe de cada una de éstas se encontraría en su Cuartel Central para recibir los resultados de los Distritos y comunicarlos al Gobierno. La formación sería normal, y una vez contados los electores, los Capitanes ocuparían la cabeza de su compañía alineada en una sola fila, como señal de que el recuento se había efectuado. Como no se podía ser oficial sin saber contar y escribir, el Gobierno estaba seguro de que aquel recuento no se haría por tarjas. A un toque de tambor, los Capitanes ocuparían el frente y dirían:

- ¡Los que no deseen la convocatoria de una Convención Nacional Constituyente, dos pasos al frente!

Nada más breve; nada más práctico, por cuanto se trataba de un dilema cuyas proposiciones estaban bien conocidas por el pue- 
blo, y en particular la de proponer en forma negativa, porque muchos monalitas tenían conocimiento de que numerosas elecciones, en países vecinos, se habian ganado por emplear dicha forma.

Antes del $1^{\circ}$ de Junio los periodistas pulsaron la opinión nacional, y los miembros del Gabinete pulsaron a los periodistas.

En la mañana de ese día se encontraban reunidos dichos miembros y conversaban animadamente respecto de la situación.

Claudio Moloso, sentado junto al fuego, parecía un poco meditabundo.

- ¿Que te preocupa, Moloso? - le preguntó uno de sus compañeros, acercándose a él con los demás. tantino.

-No, preocupado no estoy. Pensaba en el Emperador Cons-

- ¿Y en algún Código futuro?

-Eso vendrá. Ustedes recuerdan cómo se propagó el cristianismo a pesar de todas las crueldades de que fueron víctimas los cristianos, y cómo se convirtió en religión del Imperio. Los últimos emperadores paganos se dieron cuenta de que aquello no tenía remedio, y que, día más, día menos, triunfaría el cristianismo. Algún Olimpio Pitango de aquellos tiempos (o algún distinguido paleógrafo ulterior) inventó eso de In hoc signo vinces; pero lo que hubo en realidad fue que Constantino, 48 en la convicción definitiva de que aquel torrente ya no se podía contener, de que sus legiones, sus generales, y hasta sus ministros eran cristianos, se puso al frente de todos, convirtiéndose al cristianismo por más que para su cerebro de pensador no hubiera tanta distancia entre Júpiter ${ }^{49}$ y Cristo.

- No así para el político.

- Se comprende. Mucho más tarde realizó lo mismo Enrique III de Francia al declararse Jefe de la Liga. ${ }^{50}$

48 Constantino I el Grande: emperador romano en 306, trasladó la capital del Imperio a Bizancio que adoptó el nombre de Constantinopla. Parece que horas antes del combate contra Majencio, se le apareció a Constantino una cruz con las palabras In hoc signo vinces (por este signo vencerás), Constantino hizo pintar esta señal sobre su estandarte. Después de su victoria sobre Majencio decidió tolerar el cristianismo dentro del Imperio, a través del Edicto de Milán (313).

49 Júpiter: dios romano, el padre de los dioses, equivalente al Zeus griego.

50 Enrique III: rey de Francia desde 1574 hasta su muerte en 1589 . Durante su reinado continuaron las luchas religiosas del siglo XVI entre protestantes y católicos. Enrique III se declaró jefe de la Liga Santa en un intento de controlar las protestas de los católicos por las concesiones que él había hecho a los hugonotes. 
-Y más tarde aún —agregó uno de los ministros — hizo algo parecido un andaluz.

- No recuerdo el caso.

-Un andaluz de Sevilla emprendió viaje, anunciando que se iba a la Grecia de paseo, y como lo vieran por las calles de la ciudad a los pocos días le preguntaron: - ¿Y el viaje a Grecia? -Cá; impozible; ar yegá al Estrecho del Gibrartá no' zemo encontrao una bayena atravezá que no nos dejó pazá. Y con esto se despidió y luego se fue al campo a visitar unos amigos. Al regresar a los pocos días, se encontró con Sevilla abandonada; no había casi nadie. - ¡Pero hombre! ¿qué' zesto? ¿dónde está la gente? —¿Quéá é zé? que tó'er mundo za'ido a vé la bayena. - ¡Sí?! pué no hay má; me voy a vezla yo también!

-Pues ni más ni menos hizo Constantino - dijo Moloso.

-Ni más ni menos tendremos que hacer nosotros, y pasaremos por el aro de la Convención. Te advierto que el Partido Regulador ya te ha puesto en la lista de convencionales.

-Estás atrasado de noticias. Nos han incluido a todos y también somos candidatos del Partido Patriota - observó Moloso.

Pocos minutos después de medio día, sonaban todos los tambores de Monalia; a las 12 1/2 rompían filas los ciudadanos electores y militares, y a las 10 de la noche se encontraban todos los documentos en poder del Gobierno Central.

La prensa de Inglaterra dijo: - “Gobierno práctico.”

Los Patriotas, porque así lo había proclamado Olimpio Pitango, y los Reguladores, por aquello del Emperador Constantino, habían declarado - “¡Sí!”

\section{VII}

\section{MONALIA TENDRÍA UNA CONSTITUCIÓN}

Ahora ya no se trataba de un dilema, sino de una elección compleja. Era necesario que la prensa toda se preocupara de llegar a términos definitivos respecto del número de convencionales. Los periodistas Reguladores celebraron conferencias con los periodistas Patriotas, y todos ellos con los presidentes de los Comités. La Nación Monálica estaba dividida en 10 provincias; pero llegaron a un acuerdo. Convencidos todos los monalitas de que el número carece en absoluto de relaciones con la apitud, dejaron de lado los censos, y no adoptaron una representación proporcio- 
nal sino un número fijo: cinco representantes por cada una. Por otra parte, no ocurría en Monalia lo que se observa en otras naciones respecto de la densidad de población, pues como en ella todo el territorio era igualmente fecundo no había motivo para grandes diferencias.

Como era necesario desplegar mucha prudencia en la elección, y aquilatar el valor de los candidatos, y más que todo preocuparse la Nación entera de las faenas rurales del invierno, se resolvió dejar a un lado los entusiasmos y los ardores, de modo que el Gobierno Central, de acuerdo con la opinión y con el buen sentido, decretó los comicios para el 15 de Enero del año siguiente.

\section{VIII}

\section{UNA CORRESPONDENCIA CURIOSA DE TUPITAMBO. \\ - MEDIO MILLÓN DE CIUDADANOS VOTA EN MEDIA HORA. - LOS CONSTITUYENTES}

Poco antes del 15 de Enero de 1913 llegó a Monalia una correspondencia firmada por Tupitambo, el monalita que salió a correr tierras, cuando se inició la fiebre monálica de exotismo y de progreso.

Decía así:

Pocas veces ha seguido la Europa con más interés los movimientos de una nación sudamericana. Al principio, como se podía esperar, consideró que aquello era un verdadero manicomio; pero pronto se dio cuenta de que todo cuanto ocurría era debido a un fenómeno psíquico que no sólo tiene asiento en los individuos sino también en las colectividades.

Con tal motivo han sido recordados muchos casos históricos desde los tiempos antiguos.

Cuando se trató de condenar a Arístides al ostracismo, ${ }^{51}$ acercóse a él en la plaza pública un ciudadano de Atenas, que no lo conocía personalmente, y le pidió le escribiera su voto porque él no sabía hacerlo.

- ¿Qué mal te ha hecho Arístides para que votes por su destierro?

-Estoy cansado de oír que lo llamen el justo.

Sócrates 52 ha sido víctima del fastidio que causaba en muchos atenienses su enseñanza, y el mismo Aristófanes, que odiaba la nueva filo-

${ }^{51}$ Arístides: (:540-468? a.C.) político y general ateniense llamado "el Justo" por su gran integridad. Desterrado de Atenas a instigación de su rival, Temístocles, retornó más tarde para defender la ciudad de la invasión de Jerjes. Tomó parte en la organización del imperio colonial.

52 Sócrates: (Atenas 470-399 a.C.) filósofo, creador del método mayéutico. Acusado de corromper a la juventud y de atacar a los dioses, fue condenado a beber cicuta. 
sofía de aquél, ha hecho más daño a su país con sus desvergonzadas injurias al filósofo, ${ }^{53}$ que éste a las víctimas de su dialéctica. - Alcibíades, político a la moderna; ${ }^{54}$ observa que ha pasado algún tiempo sin que sus ciudadanos se ocupen de él. Es necesario que lo recuerden siempre y en todos los momentos, aunque sea por una brutalidad, para que no olviden. Tiene un perro magnífico: le corta la cola, los atenienses no hablan de otra cosa, y el perro de Alcibíades pasa a la Historia.

La Condenación de Cristo no puede fundarse política, ni criminalmente. La bondad, la virtud, la humildad no encuadran en ninguna de las culpas acusables; pero su práctica sistemática es un azote a la bestialidad de los mandones de su época y a los vicios de sus compatriotas. Muere en la cruz, y el espíritu de piedad y de justicia le compensa su martirio y lo sienta en un trono divino a la diestra de Dios.

La ingratitud, en general, es una de las manifestaciones más comunes de un fastidio inexplicable. - ¡Pero hombre! ¿cómo es que Ud., que viaja siempre y por todas partes, anda siempre desarmado? -le preguntan a un individuo. - Por una razón muy sencilla - contesta- yo no tengo enemigos porque a nadie le he hecho nunca un servicio.

En la época reciente se conoce uno de los casos más extraordinarios de fastidio colectivo, expresado por una de las huelgas más colosales que han ocurrido: la que hicieron a Pullman los obreros de sus talleres. ${ }^{55}$ Pullman fundó una ciudad para ellos. Lindas casitas con todas las comodidades modernas, construidas por los primeros arquitectos asesorados por los primeros higienistas, y alquiladas a los obreros por un precio ridículo. Teatros, escuelas, museos, iglesias, parques, distracciones de todo género y todo gratis. Las panaderías sólo podían recibir harinas de primera clase y, para mayor seguridad y confianza, cada pan llevaba la marca Pullman. Carne, verduras, pastas, vinos, té, café ... todo era repudiado ignominiosamente cuando no se presentaba de superior calidad, y, siéndolo, llevaba la marca Pullman. Libros, licores ... todo de primera ... marca Pullman. Tranvías Pullman; ropas, telas Pullman ... Pullman en todo como la más alta garantía de que en ningún mercado podría encontrarse nada mejor ni más barato. Tanto bienestar produjo el más horrible hastío, y vino la huelga. Tenían los salarios más elevados que se pagaban en los Estados Unidos. - ¿Quieren más sueldo? - les preguntó Pullman. - No; tenemos bastante; no que-

53 Se refiere a Las nubes (423 a.C.) donde Aristófanes ataca la nueva educación y la moral impartida por los sofistas. Sócrates y sus discípulos son ridiculizados, y al final, su escuela "Phrontisterion" es quemada.

54 Alcibiades: (450-404 a.C.) general y político ateniense con brillantes cualidades aunque ambicioso y sin moralidad. Provocó la derrota final de Atenas en la guerra del Peloponeso. Murió en el destierro.

55 George Mortimer Pullman: (1831-1897) industrial estadounidense, inventor de los coches Pullman en 1865. Fue presidente de la compañía Pullman Palace Car. Su experimento social, un pueblo modelo para sus trabajadores ubicado al sur de Chicago, fracasó con la gran huelga de los trabajadores en 1894. 
remos más. - ¿Qué quieren, entonces? - ... Lo que querían era gritar, desahogarse, romper algo, desfastidiarse. Estaban cansados de ver el nombre de Pullman hasta en las píldoras purgantes.

Un Rey tenía un viejo confesor, el cual habitaba una ermita entregado a sus plegarias y mortificaciones, en la más completa soledad, en el más lóbrego desamparo. Se alimentaba, como todos los ermitaños, de yerbas, de raíces, y algunas veces de frutos secos. De tarde en tarde iba el Rey a visitarlo, y aprovechaba la oportunidad para confesarse. En una de estas ocasiones, más por divertirse que por devoción, acusóse de un pecado galante, pero mortal, que asombró al buen viejo - (la memoria de los ermitaños viejos es muy débil). —¿Es posible, hijo mío, que cometas semejante pecado encontrándote en condiciones legales tan sublimes, tan incomparables? - ¿Qué quieres, padre? ¡Mutatio optima tanquam paradisus gaudeatur!56 Y hablando de otra cosa, padre ‘cómo puedes conformarte con esta horrible vida de penitencia y de privaciones? - La verdad, hijo; no me vendría mal, si pudiera, agregar de cuando en cuando algunas perdicitas a este régimen tan miserable. - Y sin más trámite, se lo llevó el Rey al palacio. Le hizo dar un aposento espacioso y bien ventilado con vista a magníficos jardines, y ordenó se le sirvieran alimentos en extremo escasos, pero que en cada almuerzo y en cada comida, le llevaran dos perdices. A los quince días, apoyado en su báculo, el ermitaño fue a despedirse del Rey. Quería regresar a su ermita. - ¿Cómo es posible eso? — preguntó el Monarca. — ¡Ay! hijo mío; ya no puedo soportar más este régimen: ¡siempre perdices! ¡siempre perdices! ¡Aaaah! - exclamó el Rey. Tienes razón, hijo: mutatio optima... - Bueno, padre, bueno; no te vayas de mi lado y pide el alimento que te agrade...

$\mathrm{La}$ opinión comienza a modificarse respecto de Olimpio Pitango. Su ilustración, su talento, su facilidad de palabra, la claridad de su mente y la excelencia de sus obras, todo revela que ha llegado a una crisis, conı se cree que ha llegado también el pueblo de Monalia. Se encuentran hastiados de ser felices; eso es lo que realmente ocurre. -Contradíceme siquiera una vez para que seamos dos - decía un Rey a su Ministro.

El tono oratorio bombástico de que ha hecho uso Pitango en sus últimos artículos es insólito en él, habituado más bien al lenguaje llano, tanto en sus discursos como en sus escritos. Aquel tono es simplemente la exteriorización de un estado alotrópico nacional cuyo primer intérprete ha sido él. Otros se suicidan, como hizo aquel banquero norteamericano, fabulosamente rico, porque nunca podía saber cuánto tenía, tal era la rapidez con que crecía su renta. Olimpio Pitango (y con él Monalia) es el ateniense que condena a Arístides y después a Sócrates, el judío a Cristo, el obrero a Pullman; es el ermitaño cansado de las perdices, es el pueblero hastiado de la ciudad con todas sus comodidades y contratiempos; es el campesino que sólo anhela tener lo suficiente para vivir en la ciudad.

56 La traducción de esta frase podría ser: Gocémonos o alegrémonos con el mejor cambio como si fuera el paraíso. 
En los diversos países que he visitado, he tenido la oportunidad de tratar con personas muy ilustradas y de variadas categorías. Preguntándoles, entre muchas otras cosas, cuál era la composición musical que más les agradaba, casi siempre me hacían enumeraciones de un eclecticismo superior; en general, preferían a todo el Himno de su patria, y en particular cuando se hallaban ausentes de ella. $\mathrm{Y}$ al inquirirles si aguantarían diez audiciones seguidas del mismo, invariablemente me contestaban: -Primero la muerte $\rightarrow 0$ algo parecido.

Un Lord inglés poseía en su país un castillo hermosísimo rodeado de inmensos parques, con espesas arboledas, que eran una gloria. Se llegó a decir que difícilmente podría encontrarse algo más hermoso. Una mañana, al asomarse por uno de los balcones, sintió una ráfaga extraña. Llamó centenares de operarios, y estos echaron todo al suelo, convirtiendo aquel Edén en una llanura pelada. Y el Lord se consideró feliz. ¡Mutatio optima!

Muchas veces, cuando leo el "Paraíso" del Dante 57 o el Profeta Isaías, ${ }^{58}$ soplan en mi cerebro ráfagas de impiedad, y me pregunto si todas esas teorías de vírgenes y legiones de jerarquías y de santos que cantan eternamente las letanías y otros peanes análogos, no sentirán alguna vez el deseo celeste de asomarse al Infierno, aunque sea de tarde en tarde, para variar un poco las delicias de la música del Infinito.

Pitango se encuentra ahora en el Continente. ¿Qué feliz debe sentirse! Allí, donde hay de todo sin ñanga-pichanga como los próceres de Monalia; donde las estatuas pueden alguna vez ser mamarrachos, pero que la gente califica de tales porque lo son, y porque han conocido personalmente a los glorificados; donde hay constituciones, códigos, cámaras, batallas campales para elegir un alcalde, venta de libretas, compra de electores, instituciones de todo género, sabios festejados de un antropomorfismo encantador, literatos elevados a las nubes porque odian a Cervantes, o no han leído Homero y se jactan de ello porque no existe un Alcibíades que los haga arrepentirse de una cachetada; no conocen a Shakespeare ni de nombre; periodistas que dicen lo que se les da la gana y nadie se asusta; devotos que por la mañana se comen los santos y a la noche se van a los casinos a oír y a ver cosas profanas de tono subido; libre pensadores que exclaman entusiasmados " $i$ Gracias a Dios

57 "Paraíso": uno de los tres cantos de la Divina Comedia de Dante Alighieri (1265-1321), donde residen los seres que por haber alcanzado perfección espiritual pueden ver a Dios.

58 El libro de Isaías: el primero de los tres libros más importantes de profetas en el Antiguo Testamento, junto con el de Jeremías y el de Ezequiel. Uno de 'los más citados en el Nuevo Testamento debido a las referencias a la edad mesiánica. 
yo soy ateo!" ... es imposible ... mientras Pitango no encuentre todo eso en Monalia, no vuelve a ella. ¿Lo tendrá?

Tupitambo

El 15 de Enero de 1913, como se había resuelto, hubo elecciones en toda Monalia, y aunque el escrutinio duró 20 días, prestaron juramento los convencionales en Molenia el 10 de Febrero.

La alegría rayaba en delirio, y si los belgas hubieran tenido la precaución de enviar para esa fecha otro cargamento de cohetes voladores y de fuegos de artificio, habrían tenido un éxito comercial de primer orden, porque los monalitas ya empezaban a aficionarse al estruendo y al olor de la pólvora, y cuando las autoridades no satisfacen esas aficiones, por aquello de las tres F del Rey Fernando de Nápoles, 59 los pueblos se encargan de hacerlo por su cuenta. Cuando un fraile inventó la pólvora en Europa, 60 hacía 2.000 años que los chinos la usaban para sus diversiones en forma de petardos y otros artificios, porque eran unos salvajes; pero a los buenos cristianos de Europa lo primero que se les ocurrió fue meter ese polvo negro en un tubo de fierro, ponerle un tapón del mismo metal o de plomo y arreglar sus contiendas civiles y religiosas, directamente o por elevación, con tales instrumentos, porque no eran salvajes.

Lo primero que se notó al reunirse la Convención fue la carencia de prácticas parlamentarias; pero allá se las compusieron: lo principal era tener 50 convencionales.

59 Las tres F del Rey Fernando de Nápoles: "forza", "festa" y "farina". En 1901 Holmberg había expresado: "¿Será cierta la afirmación de Fernando de Nápoles de que a los pueblos se domina con tres efes, forza, festa y farina?". "De Siglo a Siglo", ob. cit., 52.

60 No se sabe con certeza la fecha de la invención de la pólvora. Parece que los chinos la usaban en la antigüedad y que los griegos tenían una mezcla conocida como el fuego griego, que era el terror de sus enemigos. Sin embargo muchos se atribuyen el honor del descubrimiento, entre ellos los chinos, los hindúes, los griegos, los árabes, los ingleses (Roger Bacon) y los alemanes (Berthold Schwarz). Holmberg probablemente aluda a Roger Bacon (¿1220-1292?) filósofo, científico, astrónomo, alquimista, que fue a partir de 1257 un fraile. Relatos exagerados acerca de sus invenciones y experimentos circularon en la literatura popular (E. B. 10: 1038, 2: 1000). 
En esa primera sesión, llenadas las fórmulas de revisión de poderes y proclamación de la lista, se pasó a cuarto intermedio para convenir en la designación de Presidente y de los convencionales que formarían las diversas comisiones.

Una vez que la sesión se reanudó, Claudio Moloso fue elegido por unanimidad para ocupar la presidencia. Hecho esto, uno de los convencionales pidió la palabra, que le fue concedida.

- Señor Presidente, Señores Convencionales: Propongo que se suspenda hasta mañana la constitución de las comisiones. Durante el cuarto intermedio hemos confeccionado las listas correspondientes; pero esto se hizo por la inspiración del momento. Convendría que todos los señores convencionales las estudiaran, y que presentasen mañana sus observaciones. Éste podría sentirse más apto para ser miembro de otra en que no figura, y aquél no tendría inconveniente en observarlo respecto de otro.

-Apoyado.

- Si nadie toma la palabra se va a votar. Los que estén por la negativa, de pie ... Aprobado por unanimidad. - Bien. Ahora, Señores, conviene que resolvamos hoy mismo, para poder orientarnos en todas las tareas ulteriores, y como base fundamental, qué forma de gobierno debe consignarse en el preámbulo de la Constitución que vamos a redactar.

Y los convencionales todos inclusive el proponente, se pusieron de pie.

— iA la una! ¡a las dos! ¡a las tres!

No se oyó más que una palabra:

— ¡Republicana!

Monalia se había salvado de numerosos partidos políticos probables.

En antesalas:

- No puede negarse que algunas monarquías son más baratas -dijo uno.

- Monalia es una República en la que cada ciudadano será rey absoluto de su derecho y de su deber, y cuando tal forma de gobierno empiece a ser cara, los mandatarios irán a dar un paseo por el Manicomio Tarpeyo - agregó otro.

-Y ese será el preámbulo - insinuó un tercero, y no se tocó más el punto.

Al día siguiente se instalaron las comisiones y desde ese momento empezaron a trabajar. 
Algunos convencionales propusieron se creara otra comisión intermediaria que diera unidad de forma a la redacción, una vez terminada la tarea de las otras.

- La forma definitiva vendrá de por sí, porque, de cualquier modo que se presente al estudio, siempre habrá que modificar algo. En todo caso, ya tendremos tiempo de hacerlo en oportunidad -dijo Moloso.

Aquello era evidente.

Al retirarse del recinto, Moloso iba refunfuñando:

- iYa empezaron! la última proposición parece cosa de atavismo lejano. ¡Malhaya con las administraciones papeleras!

Cuando las comisiones terminaron sus proyectos a los veinte días, se iniciaron las discusiones, sobrias, categóricas, sin flores ni reticencias. Allí no se medía el juicio ni el talento por el número de palabras.

\section{IX}

FEMINISMO.

- UN TELEGRAMA

Una vez abierta la sesión y leída el acta de la precedente, aprobada y firmada, pidió la palabra el diputado Toribio Albarda.

- Señores - dijo- sin desconocer el tesón, laboriosidad y competencia de la comisión redactora del proyecto de constitución, me será permitido recordar que existe un claro muy importante en ese proyecto. Verdad es que la proposición que voy a presentar tiene acomodo en cualquier momento de las discusiones, si se considera desde un punto de vista exclusivamente incidental; pero una vez que hemos entrado en este glorioso período de reformas institucionales, no sería difícil que, tratado al fin, tuviéramos que hacer numerosas modificaciones en el texto definitivo: me refiero al papel que debe representar la mujer dentro del fundamento del nuevo régimen político que nos empeñamos en implantar en Monalia.

Voy a explicar mi idea.

Desde los tiempos heroicos hasta los momentos actuales, la mujer ha tenido oportunidad, en más de una ocasión, de asumir el mando supremo nacional, y si, como es de justicia, comparamos la figuración política y actos de gobierno de algunos reyes y emperadores, con los de muchas reinas y emperatrices, no serían éstas, seguramente, quienes llevarán la peor parte. Ni argüiré tampoco citando casos contemporáneos ocurridos en monarquías de régimen constitucional y parlamentario porque en ellas están restringidas las iniciativas del monarca, sea varón o sea mujer; pero tomando un lapso considerable de tiempo que comienza con Pentesilea, reina 
de las Amazonas, ${ }^{61}$ y termina en Catalina II de Rusia, 62 durante el cual ha tenido una acción relativamente débil el derecho parlamentario, ¿quién podría considerar a Baltasar, 63 a Sardanápalo ${ }^{64}$ y a Nabucodonosor, 65 que llegó hasta alimentarse con las yerbas de los campos, y aún tomados en conjunto, con la inmortal Semiramis?66 ¿Acaso es inferior Isabel de Inglaterra ${ }^{67}$ a Carlos I68 y a Carlos II69 juntos? Es cierto que Isabel le hizo cortar la cabeza a María Stuart; ${ }^{70}$ pero no lo es menos que

${ }^{61}$ Pentesilea: hija de Ares y reina de las amazonas. Fue muerta por Aquiles en el sitio de Troya.

62 Catalina II de Rusia, la Grande: (1729-1796) hija del príncipe alemán Christian Augustus de Anhalt-Zerbst y su esposa Johanna Elizabeth de HolsteinGottorp. A la muerte de Pedro III, su esposo, ella asciende oficialmente al trono. Durante su reinado, después de las dos guerras con Turquía, Rusia gana la Crimea y obtiene salida al Mar Negro. Mujer culta y hábil, favoreció las artes y las letras ( $E$. B. V: 77-79).

63 Baltasar: rey de Babilonia hijo de Nabonid, fue destronado en 538 (?) a.C., por Ciro, rey de Persia, quien conquistó Babilonia cuando Baltasar estaba entregado a los placeres.

64 Sardanápalo: rey de Asiria, según la tradición griega fue el arquetipo del príncipe afeminado que ante el sitio de Babilonia (648 a.C.) se quemó él y sus esposas. Para los asirios éste fue un acto inevitable que el poderoso rey esgrimió para asustar al autor de la rebelión, su medio hermano.

65 Nabucodonosor: rey de Babilonia (¿605-562? a.C.) durante su reinado los pueblos de Siria y Palestina se hicieron sus tributarios. Convirtió a Babilonia en una de las siete maravillas del mundo, famosa por los jardines colgantes.

66 Semiramis: (alrededor del 800 a.C.) princesa asiria sobre la que se han acumulado muchas leyendas. Según ellas, Semiramis, mujer de gran influencia y poder, fue reina de Babilonia. Durante su exitoso reinado erigió grandes ciudades (entre ellas Babilonia), abrió caminos y levantó estatuas.

67 Isabel de Inglaterra, Elizabeth I: reina de Inglaterra e Irlanda desde 1558 hasta 1603 . Hija única de Henry VIII y de su segunda esposa Ana Bolena. Soberana enérgica, defensora del protestantismo contra Felipe II de España, condenó al cadalso a Mary Stuart, quien al ser apoyada por los grupos católicos que querían apoderarse del trono, constituía una amenaza para su reinado. Alentó la colonización y el comercio y protegió las artes y las letras.

68 Charles I: rey de Gran Bretaña e Irlanda (1625-1649) durante su reinado se produjo la guerra civil entre los parlamentarios y los realistas. Charles, incompetente para controlar estos sucesos, realizó oscuros negocios con las partes beligerantes. Cromwell decidió la ejecución del rey como un acto de justicia por haber orquestado el resurgimiento de la guerra civil.

${ }^{69}$ Charles II: hijo de Charles I, rey de Gran Bretaña e Irlanda (1660-1685) su alianza militar y económica con Francia contra Holanda motivó una crisis en su reinado.

70 Mary Stuart: (1542-1587) reina de Escocia y de Francia al casarse con Francisco II. A la muerte de éste regresa a su país, donde tuvo que luchar contra la Reforma. Abdicó en 1567 debido a la insurrección originada por su casamiento con el asesino de su segundo marido, lord Darnley. Huyó a Inglaterra, donde fue ejecutada por la reina Isabel de Inglaterra por su intervención con los grupos católicos. 
Cromwell ${ }^{71}$ se la cortó a Carlos I. María Teresa ${ }^{72}$ tuvo a raya a Federico el Grande, ${ }^{73}$ y es un hecho comprobado que Napoleón I jugaba al gallociego para divertir a María Luisa. Pentesilea como reina pudo presentar combate al mismo Teseo, ${ }^{74}$ combate en el que su ejército reveló las más altas dotes de aptitud militar, y si fue vencida se debió a los Hados y a las condiciones personales del hijo de Egeo más que a su experiencia incompleta, porque él no había puesto aún en juego su táctica con Ariadna ${ }^{75}$ y más tarde con Fedra, ${ }^{76}$ sino con Antíope, ${ }^{77}$ pero era conocedor, y no es verosímil que se preocupara de las mutilaciones por etimología más que de la estética. ${ }^{78}$ Las relaciones exteriores de Catalina de Rusia son tan grandes y tan variadas, como las interiores, y si su gloria personal y política se ha de comparar con la de Luis XIV,${ }^{79}$ ¿quién no reconoce que Catalina era de mayor pujanza?

¿Acaso existe alguna función viril que no haya sido más de una vez desempeñada por una mujer?

71 Oliver Cromwell: (1599-1658) lord protector del Estado Común de Inglaterra, Escocia e Irlanda. Como jefe de la guerra civil entre los realistas y parlamentarios, decidió que la ejecución de Carlos I (1649) era un acto justo por sus crímenes.

72 Maria Teresa de Austria: (1717-1780) hija de Carlos VI, reina de Hungría y de Bohemia. Reina enérgica que luchó contra Federico II el Grande, en la guerra de Sucesión de Austria y en la de los Siete Años.

73 Federico II, el Grande: (1712-1786) rey de Prusia a partir de 1740. En la guerra de Sucesión de Austria, se apoderó de Silesia y en la de los Siete Años, resistió a Rusia, Francia y Austria. Después de la guerra, reconstruyó su estado.

74 Teseo: el gran héroe de las leyendas áticas y el hijo de Egeo, rey de Atenas. Extendió el territorio ático al istmo de Corinto.

${ }^{75}$ Ariadna: hija de Minos de Creta, ayudó a Teseo a salir del Laberinto con un hilo de joyas después de que él mató al Minotauro. La leyenda a partir de este momento diverge: ella fue abandonada por Teseo y se mató, o fue llevada a Naxos y allí murió o se casó con Dionisio, o se murió al dar a luz.

76 Fedra: hija de Minos de Creta y hermana de Ariadna. Se casó con Teseo y se enamoró de su hijo Hipólito. Éste la rechazó y ella se suicidó.

77 Antíope: según las distintas historias tejidas alrededor de las mujeres amazonas, Teseo solo o con la ayuda de Hércules, atacó a las amazonas y capturó a la princesa amazona Antíope. Las amazonas luego invaden el Ática, pero son finalmente vencidas. Teseo se casa con Antíope y tiene un hijo, Hipólito.

78 y no es verosímil que se preocupara de las mutilaciones por etimología más que de la estética: sutil ironía de Holmberg que alude a la etimología de la palabra amazona que en griego significa "sin seno". Se decía que las amazonas mutilaban el seno derecho de sus hijas para evitar que obstaculizara el uso del arco.

${ }^{79}$ Luis XIV: el Rey Sol (1638-1715) rey de Francia de 1643-1715, casado con María Teresa de España. Durante su reinado Francia adquirió gran esplendor en las artes y las letras y se produjeron reformas en la economía y el ejército. 
Los griegos, esos grandes analistas de la aptitud humana, se pintaron en sus dioses, en lo cual coincidieron con todos los otros pueblos, y no es $\sin$ motivo que hicieron de Marte 80 el dios de la guerra. Pero la actuación de Marte en la guerra es la de un soldado valiente hasta la temeridad; pero no pasa de ahí: tiene a su cargo la parte ruda, brutal y sangrienta de la batalla a la que marcha precedido por Belona, ${ }^{81}$ por la Discordia. ¿Cuál de los dioses tenía a su cargo las funciones superiores de la guerra: la disciplina, la táctica, el genio de los combates, la dirección superior de los preparativos y el estímulo de los sentimientos de humanidad con los heridos y de piedad con los muertos? Minerva, 82 la de los ojos glaucos y cabellera negra como el Tártaro ${ }^{83}$ con reflejos de violeta como los del ala de cuervo; Minerva, Athena, ${ }^{84}$ que da su nombre a la ciudad por ella fundada y porque triunfa en la contienda con su colaborador Neptuno que ha hecho surgir de la tierra, de un golpe de tridente, un caballo blanco, símbolo de la guerra, y ella, Palas, Epipírgites, con un golpe de su lanza, un olivo, que es símbolo de la paz. ${ }^{85}$ Cuando Marte recorre las filas enardeciendo el corazón del soldado e infundiéndole en la sangre la ira y la crueldad que para él son el heroísmo, ella, Palas Glauca avanza al frente de ambos ejércitos ofreciéndoles con una rama de olivo la oportunidad de dominar la rudeza de sus pasiones, que es el heroísmo de la voluntad. Mientras en los días de tranquilidad y de paz se dedica Minerva al estudio de las ciencias y de las artes, y a tejer primorosas puntillas que en el andar de los si-

${ }^{80}$ Marte: dios de la guerra, el dios más importante entre los romanos después de Júpiter.

81 Belona: entre los romanos la diosa de la guerra, a veces conocida como la hermana o la esposa de Marte.

82 Minerva: diosa romana de la artesanía, profesiones y artes, se la identifica con la divinidad griega Atenea. Se la considera también diosa de la guerra y algunos la confunden con Belona.

${ }^{83}$ El Tártaro: literalmente es el infierno; para la mitología griega y romana era la morada de los muertos.

${ }^{84}$ Athena (Atenea): protectora de la ciudad griega, Atenas, a la que dio su nombre, diosa de la guerra, la artesanía y de la razón práctica, los romanos la identifican con su Minerva.

${ }^{85}$ Referencia al mito descripto en el frontispicio del Partenón que describe la contienda para lograr el control de la ciudad entre Atenea y Neptuno (Poseidón para los griegos). Atenea aparece dando a los atenienses un olivo y Poseidón un caballo o una fuente de agua. Aunque Atenea como divinidad principal supervisa la economía del olivo, este hecho no explica totalmente el significado de la contienda. Algunas hipótesis suponen que la contienda alude a un conflicto entre el dios de los invasores griegos, Poseidón, y la divinidad nativa, Atenea, que venció al dios de los invasores al ocupar Poseidón un lugar secundario entre los griegos (E. B. 2: 668-669). 
glos llamarán de Escocia, de Bruselas, de Valencia y de Chantilly, Marte se ocupa de una manera que la majestad de este recinto me impide especificar.

Ellos, y por ellos sintetizo la civilización grecolatina y pagana, relegan a la mujer, a la madre, a la esposa, al fondo del gineceo, aunque se llame Penélope ${ }^{86}$ o Cornelia, ${ }^{87}$ mientras se levanta como una encarnación del talento supremo y de la belleza soberana la figura de Aspasia,88 inspiradora de Pericles y generatriz de un siglo de oro.

Cuando se clausuran los templos del paganismo y se derrumban sus cornisas, sus acroterios, sus capiteles, sus altares y sus techos, se levanta un nuevo símbolo de infinita tristeza impregnado con la sangre de Galileo, ${ }^{89}$ de aquel hombre humilde en su infinita bondad que enseña a sus semejantes el respeto y la exaltación de la mujer, y la mujer se eleva en dignidad, en poder y en representación hasta el extremo de sentarse en el solio de los papas con el nombre de Juana, fundadora ocasional de la silla gestatoria. 90

Pentesilea, Juana de Arco e Isabel de Castilla91 marchan al frente de las huestes belicosas como si no temieran imitar el arrojo de

86 Penélope: en la Odisea mujer de Ulises, que durante los años que duró su ausencia para evitar sus innumerables pretendientes, prometió que aceptaría uno, cuando terminara de tejer el manto que destejía por la noche.

87 Cornelia: (siglo II a.C.) hija de Escipión el Africano. Después de la muerte de su esposo Tiberio, con quien tuvo 12 hijos, ella no se volvió a casar. Se dedicó a la educación de los hijos sobrevivientes, Tiberio y Cayo. Conocedora de la literatura griega y latina, sus cartas son famosas por su belleza (E. B. 6: 508).

${ }^{88}$ Aspasia: (siglo V a.C.) mujer de Pericles desde el 450 hasta la muerte de éste. Figura controversial dentro de la sociedad ateniense por su vida privada, respetada por los filósofos, fue célebre por su talento y belleza.

89 Galileo Galilei: (1564-1642) matemático, astrónomo y físico italiano. Con la creación del telescopio astronómico probó que la tierra giraba alrededor del sol, descubrió las leyes de la caída de los cuerpos, el principio de la inercia, el termómetro.

90 Según la leyenda existió una mujer Juana, que fue Papa entre Leo IV (847-855) y Benedicto III (855-858). No se sabe con exactitud si ésta fue sólo una figura legendaria, pero a partir del siglo XIII se la menciona regularmente en la literatura (Petrarca, Boccaccio). Existen varias historias acerca de ella, la más antigua data de 1261, pero es desde el siglo XIV que aparece con el nombre Joan, mujer inglesa que se enamora de un monje benedictino y vestida de hombre lo acompaña a Atenas. Después de aprender diversos conocimientos va a Roma donde la hacen cardenal y luego Papa (E. B. 13: 8).

91 Isabel I de Castilla: (1451-1504) tras casarse con Fernando II de Aragón, se unieron los dos reinos. La política común de los llamados Reyes Católicos, fue de gran trascendencia para España. 
Nemrod, ${ }^{92}$ de Aquiles, ${ }^{93}$ de Alejandro, de Aníbal, de Genghis-Khan, ${ }^{94}$ de Bayardo, 95 de Turena, ${ }^{96}$ de D'Artagnan ${ }^{97}$ o de Napoleón en Arcole. ${ }^{98}$

Las sibilas y las pitonisas de la Grecia hacían temblar a los poderosos del mundo.y de la vida con la profundidad misteriosa de sus predicciones, mientras que en Sagunto, ${ }^{99}$ en Numancia ${ }^{100}$ y en Zaragoza ${ }^{101}$ las mujeres derraman su sangre patriótica al lado de sus hijos, de sus esposos, de sus hermanos y de sus padres. ¿Acaso gritaban más que ellas los descamisados de la Revolución Francesa entre las turbas formidables que llevaron a sus reyes al patíbulo?

$¿$ ¿Hubo entonces una sola que se desmayara al contemplar el moflete ensangrentado de Luis XVI 102 o la ideal blancura del cuello segado de

92 Nemrod: rey fabuloso de Caldea, llamado en el Génesis: "bravo cazador delante de Yahvéh" (GE 10: 8-9).

93 Aquiles: hijo de Peleo y Tetis, famoso héroe griego de La Ilíada, mató a Héctor en el sitio de Troya. Paris le dio muerte por medio de una flecha lanzada a su talón.

94 Genghis-Khan: nombre real: Temutchin (¿1160?-1227) uno de los grandes conquistadores de la historia, es el creador del primer imperio mongol. Su ejército victorioso fue desde la China a Rusia.

95 Bayardo: Pierre Terrail, señor de Bayard (Francia, é1473?-1524) conocido como el "Caballero sin miedo y sin tacha" por su heroísmo y justicia. Uno de los más hábiles comandantes de su época que por espionaje obtenía importante información sobre sus enemigos.

96 Turena o Turenne (Enrique de La Tour D'Auvergne, vizconde de Turena): (Francia, 1611-1675) uno de los grandes capitanes franceses, cuyas campañas Napoleón recomendaba a sus soldados que leyesen una y otra vez. Se destacó principalmente en la Guerra de los Treinta Años; sus victorias decidieron la paz de Westfalia (1648) y el Tratado de Los Pirineos (1659).

97 D’Artagnan: (¿1611?-1673) Charles de Batz de Castelmore, conde d'Artagnan, capitán de la Primera Compañía de los Mosqueteros del Rey, murió valientemente en el sitio de Maestricht en 1673. La guardia de los Mosqueteros, que era la elite de las tropas del rey, fue creada por Luis XIII (Courtilz de Sandraz, Memoirs of Monsieur D'Artagnan, trad. e introduc. Ralph Neuill [London, H. S. Nichols, 1925], 3 vols. (pp. V-XVI).

98 Napoleón en Arcole: Victoria de Napoleón sobre los austríacos dirigidos por Alvinczy (1796) en Arcole, provincia de Verona, Italia.

${ }^{99}$ Sagunto: ciudad de Valencia, España, célebre por la resistencia que ofreció a Aníbal, quien después de un prolongado sitio en el 219 a. C. se apoderó de ella.

100 Numancia: ciudad de la antigua España, después de un largo sitio Escipión Emiliano la destruyó en el 133 a.C. Sus habitantes decidieron morir quemados, antes que rendirse; fue importantísimo el papel de las mujeres.

101 Zaragoza: capital de la provincia de Zaragoza en Aragón, España. Resistió heroicamente en 1808 y 1809 el sitio de las tropas francesas.

102 Luis XVI: (1754-1793) rey de Francia desde 1774, casado con María Antonieta de Austria. Su debilidad, la influencia nefasta de sus ministros y de su 
María Antonieta?103 ¿Tenían sus pulmones menos energía para proclamar ante el mundo estupefacto que el lema futuro de la Francia y de la Humanidad sería: ¡Libertad! ¡Igualdad! Fraternidad?

Hace algo más de veinte siglos una bella joven tan vibrante como las cuerdas de su lira se asomaba cantando por última vez al borde de un abismo. Dulce, tierna y voluptuosa era su voz. La inspiración rozó su frente, y de sus labios y de sus dedos brotó un dialecto eólico, un ritmo delicioso que dos mil años antes inventara el poeta Vasishthas ${ }^{104}$ para elevar su plegaria a Karma. ${ }^{105}$ La poesía, como arte, no ha creado jamás verso más delicado, y la sola cadencia de su marcha inspira sentimientos de amor y de ternura. Si Safo106 lo inventó por segunda vez, gloria para ella; si no lo inventó, gloria para su ciencia paleoscópica. 107

¿En qué no han descollado las mujeres cuando se han propuesto resaltar? En las artes, en las ciencias, en las industrias - en todo saben poner una nota de elevación, de gracia y de cultura que ningún hombre podría igualar. Como administradoras son insuperables, y si alguna vez

esposa, lo hicieron un rey impopular. Su caída fue ocasionada no sólo por sus vacilaciones y por la situación económica, sino porque no comprendió el surgimiento de las nuevas fuerzas liberales y democráticas de la Revolución Francesa. Fue condenado a muerte y ejecutado.

103 Maria Antonieta de Austria: (1755-1793) esposa de Luis XVI. Su nombre se asocia a la caída de la monarquía francesa por sus extravagancias, que derivaron en una crisis económica, y especialmente por resistir los cambios de la Revolución Francesa que finalmente depuso la monarquía. Fue ejecutada unos meses después de Luis XVI.

104 Vasishthas: probable autor del himno VIl de uno de los libros Vedas, el Rigueda, escrito en sánscrito entre 2000 o 1500 a.C. El libro contiene un total de 10 himnos brahmánicos destinados a la comunidad como libro de oraciones (E. B. 19: 958).

105 Karma: palabra sánscrita que significa actos o acción; creencia según la cual cada acción buena o mala recibe una retribución. En el pensamiento hindú, esta doctrina se ha combinado con la doctrina de la transmigración, explicando así la presencia de cualquier dolor o placer injustificado como resultado de acciones previas. La doctrina aparece en el brahmanismo (E. B. 13: 240).

106 Safo: la más grande poetisa de Grecia, nació en Lesbos alrededor del 600 a.C. Escribió poemas, elegías, epigramas, en una lengua que parece no era la literaria sino el dialecto usado diariamente, logrando una conjunción inusual de perfección formal, efecto e intensidad de emoción (E. B. 19: 985).

107 Paleoscópica: neologismo de Holmberg formado probablemente con la fusión del prefijo griego páleo (gr. antiguo) y la raíz griega scop (skopeo: ver). La "ciencia paleoscópica" de Safo fue la que permitió reproducir (ver) los versos del pasado. 
han malversado fortunas de tontos, se debe a que los tontos, con la prolijidad de un pedagogo chino, les enseñaron a hacerlo.

¡Ah Señores Convencionales! Se ve que aquí no está el maestro, el gran maestro de la elocuencia monálica, porque si estuviera en este recinto ya habríais votado, en el estruendo de las aclamaciones, la intervención de la mujer en todas las tareas que corresponden a la evolución política y social de Monalia. ¡Sí, Señores Convencionales! ¡Gimiendo en un cuasi-ostracismo, nos envía su sombra la personalidad imponente de Olimpio Pitango!

A pesar de la ambigüedad sibilina de algunas expresiones; no obstante las reticencias escondidas en la sucesión de los ejemplos contenidos en este discurso, y más por la entonación que por el fondo, los convencionales y la barra aplaudieron estruendosamente al orador significándole así que con toda probabilidad llegarían a entenderse todos en tan delicado asunto.

Aceptado el tema en principio y reconocida la oportunidad probable, la Convención continuó ocupándose de la tarea general.

El discurso de Toribio Albarda fue transmitido por telégrafo a todos los pueblos de la Nación, al Continente y a otros países, y en la noche de ese mismo día se recibió en Molenia el telegrama siguiente:

\section{Buenos Aires, Julio 20 de 1913:}

Al Convencional Toribio Albarda ¡Salud! La luz se hará. Comienza la alborada para el mundo entero. Tupitambo es un precursor también, pero tú eres un Demóstenes, ${ }^{108}$ Toribio. Así lo dije en el Comité Central después de oírte en el banquete del 29 , y hoy realizas lo que predije entonces; tienes el nervio de un Botijo y la flexibilidad de Cachimbo Pérez. Tu honda penetración de las obras de Maquiavelo ${ }^{109}$ te permitirá desenvolver gradualmente el despliegue de los grandes caracteres desconocidos

108 Demóstenes: (384-322 a.C.) orador y político ateniense que impulsó a los griegos a que resistieran a Filipo II de Macedonia. Sus discursos proporcionan importante información sobre la vida política, económica y social de Atenas (E. B. 7: 229).

109 Nicolás Maquiavelo: (1469-1527) político, pensador y escritor italiano cuya penetrante visión de la política contemporánea y de la naturaleza humana se materializó en el tratado El Príncipe, sus Discursos sobre la primera década de Tito Livio y obras teatrales como La Mandrágora. 
y repudiados por la exégesis histórica, entre los cuales figura en primer plano Otelo y D'Artagnan. ¡No vaciles! Monalia reacciona, y a su frente los hombres del Gobierno Central que deseaban a todo trance retardar indefinidamente la creación de un Parlamento, olvidando que Licurgo quiso, 110 y lo realizó, fabricar un pueblo para sus leyes, mientras que Solón, ${ }^{111}$ adivinando con espíritu genial los principios más elementales de la evolución del derecho público redactó un código de leyes de acuerdo con las aptitudes de ese pueblo, muchos siglos antes de Hugo, ${ }^{112}$ de Savigny 113 y de todos los constitucionalistas contemporáneos. Cuando el parlamentarismo como en Francia da por resultado un exceso de legislación se cae en el peligro de no poder orientarse, y de aquí los frecuentes cambios de régimen de gobierno desde el 89 hasta ahora. La Rusia autócrata no durarả veinte años, porque la Rusia no ha sabido o no ha querido darse cuenta de que el parlamentarismo es una válvula de escape de la democracia infiltrada en el espíritu de la civilización y del progreso. Cuando los pueblos no pueden decir lo que piensan, lo hacen. La España que tiene muy pocos sabios de corte alemán, francés o inglés, se ha derramado en profunda sabiduría por sus refranes, y cuando dijo: Perro que ladra no muerde levantó un monumento inmortal de política positiva, con mucha, muchísima anterioridad a la Filosofía de Augusto Comte $114 \mathrm{y}$ a todos los fárragos enormes que se han publicado para demostrar que 3 y 2 son 5 . - Junto con esta explosión de entusiasmo por el espíritu que revela tu discurso en la Convención, te envío una advertencia. Para mí, esto no es un ostracismo sino una escuela. - Después de firmar, y antes que se seque la pluma, continuaré escribiendo, porque tengo mucho que decirte.

Olimpio Pitango

110 Licurgo: legislador espartano (s. VII a.C.) creador de la mayoría de las instituciones de Esparta.

111 Solón: político ateniense, uno de los primeros redactores de leyes en Grecia, nació alrededor del 640 a.C. Sus leyes tendían a reformas económicas, sociales y constitucionales.

112 Victor Hugo: (1802-1885) poeta y novelista, figura señera del romanticismo francés. Entre sus obras: Los miserables, Hernani, Las contemplaciones, Nuestra Señora de París.

113 Friedrich Karl Von Savigny: (1779-1861) jurisconsulto alemán. Sus importantes contribuciones a la jurisprudencia fueron: revelar la continuidad de las antiguas instituciones en las del presente; establecer las bases de la sociología legal y articular los métodos de investigación histórica (E. B. 20: 14C).

114 Augusto Comte: (1798-1857) filósofo positivista francés creador de la ciencia sociológica, autor de Curso de filosofía positiva, obra maestra de la filosofía del siglo XIX. 
El día 21 de Julio todos los diarios de Monalia reproducían el telegrama anterior.

A las 10 de la mañana los miembros del Gobierno Central se encontraban reunidos en el salón de sesiones o de acuerdos.

Claudio Moloso se paseaba con aire pensativo y sólo de cuando en cuando se acercaba a la chimenea por dos o tres minutos, extendía las manos hacia el fuego, se las frotaba y volvía a pasearse.

- ¿Qué te preocupa, Claudio? - le preguntó un personaje gordo, petizo, 115 muy blanco y completamente afeitado, y que, por sus funciones dragoneaba de Ministro del Interior.

- ¿ No tienes acaso tú alguna preocupación hoy?

- Absolutamente ninguna.

-Es extraño. No; no es extraño. No me refiero a tus asuntos particulares sino a los de política nacional.

-No veo por qué motivo me ha de preocupar la política nacional. Ayer se reunió la Convención que ha trabajado con bastante juicio, exceptuando la pérdida de tiempo que ha ocasionado ese otro loco de Toribio Albarda con su discurso.

-Estás equivocado. Toribio es un muchacho de talento y un gran político. ¿Has leído el telegrama de Olimpio?

- Me he reído en grande. Había pensado que estaba loco de remate; pero ahora se encuentra en una situación mucho más grave: es un loco razonante.

-No; se creería que no has leído Esquilo. ${ }^{116}$ Acuérdate del consejo de Océano a Prometeo: "El secreto del hombre prudente está en parecer loco". 117 Monalia es un gran país. Si su población tuviera menos juicio, harías un triste papel en el desempeño de tus funciones -agregó Claudio moviendo la cabeza- Olimpio no está loco ni lo ha estado nunca. Sus extravagancias son clarines que están ensayando las dianas de sus victorias. Déjalas a un lado y procura cambiar de opinión como Tupitambo. Las verdades del

115 petizo: Arg., Chile, Bol., Par., persona de baja estatura.

116 Esquilo: (¿525?-456 a.C.) uno de los grandes poetas trágicos, autor de la trilogía Orestiada, y las tragedias Los Persas, Las suplicantes, Prometeo encadenado. Esta última obra, cuyos personajes se mencionan en el texto, es la historia de Prometeo que salvó a la humanidad al desafiar con el fuego a Zeus. Por esto fue condenado a estar atado a una roca. Aquí fue visitado por un coro de ninfas, por su padre Océano y por Hermes. Al final de la obra Prometeo se sumergió en el Tártaro para sufrir más torturas (E. B. 1:218).

${ }^{117}$ La cita no es literal: "Océano. Lo mejor para el hombre sabio es no parecerlo": "Oceanus. The best thing for a wise man is to seem unwise." (Aeschylus, Prometheus Bound, trad. Warren Anderson. [Indianapolis, New York, The Bobbs Merrill, 1963] 19). 
telegrama son aforismos que revelan su elevado criterio político. Es un profeta, es un vidente.

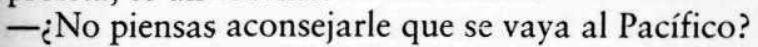

-i¿Yo?! Ni en sueños se me ocurriría cometer tal insensatez. ¿No te has fijado en este final? Mira: "Para mí esto no es un ostracismo, sino una escuela". Pues bien: Olimpio no se moverá de allí. Esa gran nación, a la que nos ligan tantas afinidades de costumbres, de carácter, de sangre y de familia, de todo, menos de política, ha cometido lo que nos hemos empeñado en designar como todas las locuras de los ensayos de la democracia; pero fíjate bien en mis palabras: de la democracia. En su desenvolvimiento político de un siglo, sólo una vez, y eso en los comienzos y bajo la influencia de los humos de un banquete, un oficial Duarte, que tenía el vino hiperbólico, brindó por el Emperador Saavedra, y ya sabemos lo que hizo y dijo Mariano Moreno; 118 pero me he equivocado. Hubo otro caso, tan inocente y tan sincero, que sólo puede atribuirse al glorioso empeño de colocar a la patria en la que consideraban las mejores condiciones de gobierno. $Y$ mira que allí estaban los próceres legítimos, no los próceres de Olimpio: la tentativa de fundar una monarquía del Río de la Plata, lo que fracasó, no por impracticable, sino porque al preferir el General Belgrano, el hombre íntegro, probo, intachable, un monarca de la dinastía de los Incas, ${ }^{119}$ le mató Dorrego el punto diciendo:120 "No fal-

118 Cornelio Saavedra: (1759-1829) y Mariano Moreno: (1778-1811) próceres argentinos de la Revolución de Mayo (25 de Mayo de 1810). Desempeñaron, respectivamente, los cargos de presidente y secretario de la Primera Junta de Gobierno (1810). Durante esta época las fricciones entre ambos surgieron porque frente a la idea de un cambio gradual propuesto por Saavedra, Moreno era partidario de una revolución institucional guiada y controlada por Buenos Aires. Al renunciar Moreno, la Junta fue reemplazada por el Triunvirato y Saavedra fue acusado de apoyar el gobierno monárquico de la princesa Carlota Joaquina.

119 Manuel Belgrano: (1770-1820) patriota argentino, héroe de la Independencia y creador de la bandera. En 1816 propuso al Congreso de Tucumán un plan de acción relativo a tres aspectos: 1 ) declarar la independencia (lo que se hizo el 9 de julio), 2) adoptar una bandera nacional, 3) establecer una monarquía de un príncipe inca. Esto último fue un tema muy debatido en el medio. Los que estaban en favor opinaban que la monarquía inca permitiría unir el Alto Perú y el Noroeste argentino con Buenos Aires.

${ }^{120}$ Manuel Dorrego: (1787-1828) militar argentino, ardiente defensor del federalismo fue gobernador de la provincia de Buenos Aires. Fue asesinado por Lavalle quien creyó que con su muerte se erradicaría el federalismo. De espíritu apasionado, se enemistó con Belgrano cuando luchó en las campañas libertadoras bajo sus órdenes. Más tarde a raíz de su activa militancia en el periódico Crónica argentina, que combatía el periódico El Censor defensor del gobierno monárquico propuesto por Belgrano, fue desterrado. 
taría sino que nos arrodilláramos al pie de un rey con chancletas". Y, como siempre, acertó por carambola, su espíritu inquieto, mordaz, turbulento; y por herir a Belgrano una vez más, arrojó el proyecto de monarquía al limbo de los nonatos. La risa pudo más que el patriotismo. Pero estoy impaciente por conocer la continuación del telegrama de Olimpio. Debe haberse sentido inspirado, porque dice que va a seguir escribiendo antes que se le seque la pluma.

- La verdad, Claudio, te desconozco.

- ¿Qué quieres? No olvides lo que hizo el Emperador Constantino. Por otra parte, y a semejanza del andaluz, me voy a "Gibrartá a ver la ballena".

\section{$\mathrm{X}$}

\section{UNA CARTA DE OLIMPIO PITANGO}

El 23 de julio, publicaban los diarios de Molenia la carta de Pitango.

La China, mi caro Toribio, se ha convertido en República. ${ }^{121}$ Tú sabes que en ese Imperio colosal existen dos clases de chinos, los verdaderos, los legítimos, los inteligentes, ilustrados, de la raza de Lao-Tsé122 y de Confucio, ${ }^{123}$ y los salvajes manchúes, ignorantes, brutales, siberianos, crueles, cuyos mandarines desconocen su propia dignidad cuando no pueden llenar una silla de brazos de 80 centímetros de ancho; 124 hiperbóreos que hace 500 años dominan con su dinastía en el Celeste Imperio al que procuran degradar en todas las formas para nivelarlos con ellos al descen-

121 Después de la dinastía de los manchúes la China se convirtió en República en 1912. La República fue un período de caos gubernamental que afectó la unidad nacional. Las causas del escaso éxito de la República fueron: la repetición de procesos tradicionales, la presencia de fuerzas militares que pugnaban por el poder, el desorden creado por gobernantes inexpertos e inhábiles (E. B. 5: 589).

122 Lao-Tsé: filósofo chino, nació alrededor del 600 a.C., se lo considera el fundador del taoísmo.

123 Confucio: (551-479 a. C.) maestro, teorizador político y filósofo chino cuya ideología tuvo gran influencia en la historia mundial. Insistía en el cultivo de la sinceridad y de la virtud y el desarrollo de la aptitud por medio de una educación adecuada. Su influencia en la cultura china fue profunda; proponía que sólo aquêl que poseía la virtud y la aptitud podía gobernar (E. B. 6: 310-312). Este ideario es, en parte, el de Holmberg en este texto.

124 Algunos de estos conceptos aparecen en el discurso en homenaje al profesor Baldmar F. Dobranich, inédito en mi archivo. En esta oportunidad Holmberg expresa que en China en los tiempos antiguos, "valía más un hombre con cerebro de pensador dentro del cráneo, que otro con 80 centímetros de ancho para poder llenar gloriosamente un sillón de mandarín" ("B. F. Dobranich", 5). 
der. ${ }^{125}$ Para los chinos puros, la monarquía no era una carga pesada ni degradante. Amaban a su Emperador como los japoneses actuales aman al suyo, porque Mutsuhito ${ }^{126}$ es el primer ciudadano, el primer patriota, el padre de los japoneses que lo adoran con la razón y no con el sentimiento ciego. Amaban los chinos a sus emperadores que les habían enseñado la más difícil de las escrituras, el más arpegiado de los idiomas, la astronomía con errores apenas de 500 años para la aparición de un cometa, el cultivo de la morera, del gusano de seda y la elaboración de la misma, el juego del ajedrez y tantas y tantas otras maravillas que formaban el encanto del pueblo. No han sido ellos entonces los que han hecho la República, porque ésta es la obra genuina, el resultado de la barbarie secular de los manchúes. En Chicago se fastidian porque son felices con Pullman; en China se fastidian porque son desgraciados con los emperadores manchúes. Cuando se cansen de la República llamarán a Pullman.

Los filósofos se imaginan que la humanidad es siempre la misma. Hace poco más de 300 años, los parisienses de París tenían una cavidad craneana 300 centímetros cúbicos más pequeña que ahora, y por lo tanto les faltabàn 300 centímetros cúbicos de cerebro, y esto no es una invención mía, sino una afirmación de Paul Broca. 127

¿Qué caso podríamos hacer ahora nosotros de las afirmaciones de los parisienses del siglo XVI respecto del radio, de los aeroplanos, de los automóviles, de la química, y de tantas otras maravillas actuales?

¿Qué nos han dejado los más grandes talentos de Grecia y de Roma respecto de la enseñanza del italiano, del español, del francés y del inglés, idiomas que aún no se habían formado en su época, lo que, para despistar a uno de los ministros dragoneantes, revela hasta qué punto menospreciaban a los habitantes de las tierras por ellos conquistadas?

¡Qué limitado era su saber! ¡Qué risa nos causan ahora sus filósofos, sus sabios, y sus retóricos malabaristas!

No sabían un palote de las cosas de la Naturaleza, ignorancia que ha atravesado incólume los siglos y los siglos, y si levantáramos una estadística de las cosas que ignoraban, reconoceríamos que para ser un talento en aquellas épocas remotas, bastaba tener una cucharada de sesos en un crá-

125 La dinastía de los manchúes se extendió desde 1644 a 1912 . Desde su ocupación militar tuvieron el control armado, aunque poco hicieron por el engrandecimiento del imperio.

126 Mutsuhito: (1852-1912) emperador de Japón desde 1867 a 1912. Al reorganizar la economía, la política, la educación y el orden social, sacó a Japón del aislamiento en que vivía, para convertirlo en una de las potencias mundiales. Es conocido como Meiji, el nombre que él adoptó en 1868 (E. B. 15: 115).

127 Paul Broca: (1824-1880) cirujano y antropólogo francés conocido por sus investigaciones sobre el cerebro y el cráneo. Fundó el Laboratoire d'Anthropologie de l'École des Hautes Études (1858), la Societé d'Anthropologie de Paris (1859), la Revue d'Anthropologie (1872) y la École d'Anthroplogie (1876). 
neo de cretino, en vez de un kilo y más como tenemos ahora, aunque sólo sea para alojar en ellos las matemáticas.

$\mathrm{Y}$ sin embargo, a pesar de todo el esfuerzo acumulado durante tantos siglos, todavía sienten los pueblos que ellos carecen de la necesidad de tener próceres, músicos, pintores, escultores, historiadores etc., etc. y es una necesidad más imperiosa que el hambre, porque (a lo menos en Monalia el hambre no existe) el hambre con cualquier cosa se satisface aunque sea transformándose en Nabucodonosor, mientras que no es posible eliminar del cerebro las palabras de Salomón en el Eclesiastés: “No sólo de pan se alimenta el hombre".128

Y dime Toribio, aquí para nosotros, al oído, ¿te parece que la creación de próceres y otras categorías ilustres, por más ficticias que ellas sean, desmerecerían como entidades aceptables y deseadas frente a frente de los deleites celestiales ofrecidos por Cristo y por Mahoma ${ }^{129}$ a sus prosélitos?

He sabido con sorpresa en este glorioso país que me alberga y agasaja, que unos hombres vestidos de traje talar y con un eczema circular más o menos grande en el cuero cabelludo de la cabeza, ${ }^{130}$ allí donde los frenólogos señalan el turumbico promontorial del amor propio, lo que parece un empeine por jugar con gatos, se empeñan en que los muchachos aprendan de memoria un folletito que llaman Catecismo de Astete. ${ }^{131}$ Lo he conseguido. Es una golosina que te enviaré dentro de poco para que te

128 "No sólo de pan vive el hombre", estas palabras aparecen primero en el segundo discurso de Moisés (Deuteronomio 8. 3) y más tarde las repite Jesús cuando es tentado en el desierto por el diablo en el Nuevo Testamento (Evangelio según San Mateo 4.5, y en el Evangelio según San Lucas, 4.4). Es muy probable que la ironía que se derrama en toda la obra origine la falsa paternidad y el lugar en que fueron dichas.

129 Mahoma: (:570-632?), fundador del Islamismo, uno de los hombres que más influencia ha ejercido en la humanidad al permanecer vivas como doctrina sus enseñanzas entre la población musulmana. El Islamismo creó una nueva civilización cuya ideología, según la dio a conocer Mahoma, es una religión y un sistema para la organización de la comunidad. Esta religión garantiza el paraíso a los seguidores que mueren en defensa de la fe. En consecuencia, Cristo y Mahoma prometen lo mismo.

${ }^{130}$ Eczema circular: fuerte ironía que alude a la tonsura de los sacerdotes.

131 Gaspar Astete: jesuita español (1537-1601) autor de Institución y guía de la juventud, Del estado religioso, Del estado de las viudas y doncellas. Su obra famosa Doctrina cristiana (1599) luego titulada Catecismo de la doctrina cristiana, alcanzó más de 600 ediciones. Por el testimonio de la doctora Grierson, alumna de Holmberg en la Escuela Normal de Profesoras, sabemos que este Catecismo era el que leían los jóvenes durante esa época en la Argentina: "Nosotros que aprendimos el catecismo de Astete y que nuestra frágil memoria nos hizo olvidar hace rato, hemos, en cambio, tratado de poner en práctica lo que con su ejemplo y palabra nos enseñó él [Holmberg]". ("Discurso de la Doctora Grierson", ob. cit., p. 724). Este Catecismo está actualmente fuera de circulación en la Argentina; todas las citas siguientes se hacen por la siguiente edición: Gaspar Astete, Catecismo de la Doctrina Cristiana (Pamplona, Edit. Sancho el Fuerte, 1984). 
recrees en los días nefastos cuando sopla el Viento Norte. Pero antes quiero aprender de memoria lo que se relaciona con unos cuatro infiernos, que no sé todavía de dónde han salido, o cómo se han formado. En su empeño de copiar las creencias del Oriente, los griegos enseñan que Ulises bajó a los Infiernos (a lo que está inferne, abajo). ${ }^{132}$ En el siglo XVII, Fenelon ${ }^{133}$ obliga a Telémaco a que baje también. ¿Cómo no iba a bajar de igual modo Eneas ayudado por la cadencia de los hexámetros de Virgilio?134 Y, claro está, ¿cómo no iba a bajar también Dante para buscar a Virgilio en el siglo XIV? 135 La Monalia de los Pitangos de los primeros siglos de nuestra era, tenía que hacer bajar a Cristo de igual modo, ${ }^{136}$ pero este viaje de funicular vertical no tenía más objeto que practicar una inspección ocular de los cuatro infiernos, tres de los cuales no presentaban mayor interés, pero el 20 sí. El 1०, el Limbo de los Justos o Seno de Abraham, donde residían las almas de los Santos padres precursores de Galileo, ${ }^{137}$ entre ellos el mismo Abraham. Toma la Biblia y vuelve a leer la vida de Abram y luego Abraham. ${ }^{138}$ Es uno de los ejemplos más vivos de lo que antes dije res-

132 Holmberg alude al libro XI, "Rapsodia" de La Odisea.

133 Fénelon, François De Salignac De La Mothe: (1651-1715), escritor y clérigo francés, autor del Tratado de la educación de las jóvenes (1687), Tratado de la existencia de Dios (1718), Diálogos de los muertos (1690). Telémaco (1699), la obra capital por contener sus ideas políticas fundamentales relata las aventuras de Telémaco en busca de su padre Ulises.

134 Referencia a La Eneida; la obra relata en 12 libros las aventuras de Eneas, un troyano que bajo la guía divina funda la nueva ciudad, Lavinium, que tendrá un glorioso destino en occidente. En el libro VI, Eneas desciende al mundo subterráneo, "el infierno", donde su padre le informa sobre su misión en la tierra.

135 Virgilio es quien guía a Dante en la Divina Comedia (s. XIV) a través del Infierno y del Purgatorio.

136 Este descenso de Cristo al infierno y la división siguiente de los Infiernos, 10 Limbo de los justos, 20 Infierno de los condenados, 30 Purgatorio y 40 Limbo, corresponde con algunas variantes, al Catecismo de Astete: "El infierno al que bajó Cristo Nuestro Señor después de muerto no es el lugar de los condenados, sino el limbo donde estaban los justos" (Astete, 31); "Infierno es un lugar de indecibles tormentos, que Dios tiene destinado para castigo eterno de los malos... Los condenados padecen en el infierno dos penas: pena de daño y pena de sentido" (Astete, 87); "El Purgatorio es un lugar o estado donde se purifican para ir al cielo las almas de los que mueren en gracia, debiendo pagar todavía por sus culpas alguna pena" (Astete, 88); "Las almas de los que mueren, ... si mueren antes del uso de razón y no están bautizados [van] al limbo" (Astete, 37). Holmberg hace una sátira de este Catecismo al poblarlo con categorías humanas que en esa época eran condenadas, o se salvaban, según criterios religiosos y morales.

i37 los padres precursores de Galileo: la ironía no podría haber sido más fuerte. Galileo refutó precisamente la interpretación bíblica de la creación, al demostrar, según el sistema copérnico, que la tierra giraba alrededor del sol y no era el centro de la creación, según lo sostenía Ptolomeo.

138 En el Génesis, "Historia de Abraham", Yahvéh les cambia a Abram y a Saray los nombres, por Abraham y Sara $(G E 17.5,15)$. 
pecto de la evolución de la Humanidad y en particular del criterio con que debe juzgarse la ilustración, el carácter y la moral de los hombres según los tiempos o las épocas. Pero lo más curioso es que los judíos no tenían ni tuvieron antes idea alguna respecto de tan venerable hospicio. Para ellos, las almas de los muertos eran algo así como una niebla difusa o humo tenue que vagaba sin ton ni son por las cavernas y los sótanos a semejanza de cucarachas o murciélagos translúcidos. De modo que esa cavidad intramundial se encuentra hoy desalquilada, llena de ratones y de telas de araña.

Hay aquí una planta europea que llaman Cardo de Castilla (desconocida en Monalia). Cuando los frutos están maduros y abierto el penacho que los corona, el viento se los lleva y con mayor razón cuando el grano se desprende. Estos penachos caen a veces en los patios, se acumulan en los rincones, o los llevan las brisas de una parte a otra. Así deberían andar las almas de los justos.

El $2^{\circ}$ es el Infierno de los condenados. No hay alma de persona de verdadero mérito que no esté ahí. Es el Tártaro de los griegos, ${ }^{139}$ pero mucho más refinado. En él hay tachos de aceite en el que hierven eternamente y se fríen como buñuelos los condenados. Los que entran aquí ya no salen más. Con decirte que desde Sócrates, Platón ${ }^{140}$ y Aristoteles ${ }^{141}$ hasta Darwin 142 se encuentran allí recluidos, te he dicho todo. Los más grandes bribones, la canalla específica, quedan excluidos. Ésos, y te diré por qué, van al 30 que es el Purgatorio. La psicología modernísima ha echado por tierra muchas causas de condena que fueron en tiempos pasados origen de crueldades y martirios atroces. Ahora los criminales son irresponsables ante la ley porque lo son ante la ciencia. Imagínate un caballero vestido de traje negro de etiqueta que va a pie por una calle con el objeto de hacer una visita. Al pasar junto a un charco barroso queda todo salpicado - y es natural que no se presente de visita antes de hacer limpiar las salpicaduras. Él no tiene la culpa; pero quedó impresentable. Es lo que pasa con los grandes bribones. Una vez que les limpian las salpicaduras, pueden visitar el cielo. ¡Si supieras quienes son los que ya han salido!

139 Tártaro: en La Ilíada la palabra alude a una prisión bajo tierra debajo del "infierno", a la cual eran condenados los que se rebelaban contra la voluntad de Zeus. El Tártaro es también el lugar de castigo de los perversos, e inmorales.

140 Platón: (428/427-348/347 a.C.) filósofo griego, discípulo de Sócrates y maestro de Aristóteles. Autor de los diálogos: Critón, Fedón, Fedro, Gorgias, El banquete, La Repuiblica, etcétera.

141 Aristóteles: (384-322) filósofo griego, pensador político, creador de la escuela peripatética. Autor de: Física, Poética, Metafísica, Ética a Nicómaco, Organon, etcétera.

142 Charles Robert Darwin: (1809-1882) naturalista inglés que desarrolló su teoría de la evolución orgánica en On the Origin of Species by Means of Natural Selection (1859). El evolucionismo, que refutó el creacionismo, tuvo gran impacto en el desarrollo del pensamiento moderno. 
El $4^{\circ}$ es el Limbo de los niños. A él van las almas de los que mueren sin bautismo, antes o después del nacimiento. ¡Qué injusticia!

Estos descubrimientos me han llenado de asombro. En mis estudios de religiones comparadas jamás había tropezado con este librito, y te aseguro que lo voy a examinar bien.

Te recomiendo mucho examines los archivos cuando tengas tiempo. Por todas partes hay estatuas célebres ejecutadas por los antiguos escultores de Monalia, cuando reinaba allí Apolo, ${ }^{143}$ y visitando a las familias representadas por señoras viejas restantes obtendrás muchos datos de los pintores olvidados, y quizá los cuadros originales. En esta gloriosa ciudad hay un pintor de mucho talento como escritor que posee una rara habilidad para elaborar glorias con lonas remendadas de techo de carretas y tablas viejas de mostradores de pulperías de campaña. Si lo alcanzas no lo sueltes. Al mejor cazador se le escapa la liebre, y si uno por mil de mis compatriotas olfatea que la Gioconda no es legítima, ${ }^{144}$ sino una mala copia, ya tendremos tiempo de desvanecerla por ahí. Cualquiera de las jovenzuelas que anda en esta ciudad por la calle Florida es más preciosa que aquélla y que la Venus de Medici. ${ }^{145} \mathrm{Si}$ vieras qué cabezas más lindas tienen. Pero estoy esperando que abandonen la moda de estos sombreros mamarrachos que parecen bandejas de empanadas para que adopten tanta forma graciosa y equilibrada, es decir, en armonía con su belleza.

El Coronel Ingersoll 146 que piensa mejor que un Voltaire, dice que los pillos se han inventado un cielo y los tontos un infierno. Me parece mucho más tonto aceptar tres infiernos, aunque uno de ellos es muy entretenido, ilustrado y alegre, y uno más desalquilado y mal oliente, que reconocer como legítimo de Rembrandt un hermoso cuadro que acaba de pintar Pitriflini ${ }^{147}$ envejeciéndolo fresco aún con cocimiento de tabaco, o negar la autenticidad de un original de mármol de Praxíteles, porque no le falta la cabeza y eso que tiene la nariz rota, como todas las estatuas griegas, por obra y gracia de los adeptos de Mahoma.

143 Apolo: hijo de Zeus, dios griego y romano de la poesía, de las artes, de la medicina, de los oráculos, de los rebaños, del día y del sol.

${ }^{144} \mathrm{La}$ Gioconda: pintura del artista renacentista italiano Leonardo da Vinci (1452-1519). Famoso retrato de la esposa de Francesco del Giocondo, la "Mona Lisa", realizado alrededor de 1504 . Representa un hito importante en el desarrollo del retrato por la expresión enigmática de su rostro y la vida interior que irradia.

145 Venus de Medici: representación escultórica de Venus derivada del concepto original praxitileo que durante tres siglos dominó las escuelas helénicas y romanas.

146 Robert Green Ingersoll: (1833-1899), orador, político y abogado norteamericano, gran crítico de la Biblia y defensor de la teoría de Charles Darwin en los Estados Unidos. Sirvió con el grado de coronel durante la Guerra Civil. Una de sus famosas conferencias fue, "Some Mistakes of Moses and Why I Am An Agnostic" (E. B. 12: 249).

147 No se ha podido identificar a este pintor. 
Tu amigo Pitango no te hace falta. Sigue como hasta ahora por la buena senda en bien de la patria, servidor en grado heroico, que yo me voy a ocupar en descubrir este hermoso país argentino, como han hecho recientemente muchos europeos. Hasta la próxima.

O. P.

\section{XI \\ DOCUMENTOS. - RÉGIMEN POLÍTICO DE UNA NACIÓN MODERNIZADA. - LA CONVENCIÓN}

El Patriota, Agosto 9 de 1913. En el número del 4 de Marzo del año pasado, I de la Reforma, anunciábamos el descubrimiento de una hoja de papel, oculta en un antiguo legajo, que había sido confiada al sabio paleógrafo Ñango-Pichango, y de la que dimos un facsímil fotográfico. La habilidad de Pichango, universalmente reconocida hoy le permitió interpretar el documento a los pocos minutos de haberlo recibido; pero solamente nos autorizó a consignar que revelaba la existencia de una ruina importante.

Ha transcurrido más de un año y ratifica su primer lectura, declarando ahora que no tiene inconveniente en que se publique.

Dice así:

Es bastante fácil determinar desde la cumbre mirando hacia abajo $y$ casi justo hacia el NO las ruinas por donde hoy pasan dos sendas y se descubren a veces algo veladas por arena de la playa, cubierta de conchillas. Se ven bien alineadas desde las montañas.

La importancia de esta noticia excluye todo comentario, y revela una vez más hasta qué punto alcanza la intuición genial del ilustre compatriota ausente. La dirección del Museo de Molenia debe enviar sin tardanza una comisión investigadora que, con los datos consignados, busque en todas las montañas próximas a la playa marítima, el punto desde el cual, mirando hacia abajo y hacia el Noroeste, se encuentra el asiento de las ruinas. Y conviene hacerlo ahora que la vegetación decae con los fríos, en vez de realizar el estudio en una época en que las altas yerbas cubran todos los campos.

* * *

El Regulador, al día siguiente, y en forma casi confidencial, insinuaba al Patriota la conveniencia de que esas investigaciones se hicieran precisamente a mediados de primavera cuando las yerbas se presentaran con toda su lozanía, suponiendo que tal fenómeno sería casi nulo sobre las ruinas mismas, lo que podía facilitar su descubrimiento desde la altura. 
Y luego agregaba: - El Patriota empero debe exigir que atruenen las trompetas de la Fama a causa del descubrimiento que acaban de hacer $y$ sobre el cual no ha llamado la atención debido a esa modestia delicada que lo caracteriza. Veladas a veces las ruinas por arenas de playa marina deben presentar una vegetación de aspecto tropical. Pero - continuaba El Regulador- ¿no sería conveniente averiguar, antes que todo, si el exiguo número de letras que salpican el roído documento, pueden o no dar motivo a otra interpretación? Lejos de nosotros la idea de tildar en lo mínimo las sabias interpretaciones del ilustre paleógrafo Nango-Pichango; pero no olvidemos que muchas veces los sabios mismos se dejan sugestionar por las circunstancias. La paleografía está llena de abrojos y bastará que recordemos cuántos comentarios arrancó a los arqueólogos, filólogos y lingüistas la interpretación de las palabras inscriptas en cierto vaso:

Itis Apis Potan Dabi Cone.

En prueba de las dudas que, sin ofender al hombre de ciencia podemos abrigar, nos disculpará éste que consignemos aquí la reconstrucción del consabido manuscrito hecha por uno de nuestros lectores, $y$ en la cual no se encuentra nada que se parezca a revelaciones vinculadas con la existencia de una ruina.

Se ha podido determinar apoyándose sobre base tan segura $y$ aún ajustada hasta que punto se arruinará en salud y pensando siempre de un modo descabellado. Descuidadas las precauciones desmaya su ánimo y continúa en demencia al tenerlas por patrañas.

El Patriota, Agosto 11 de 1913. El Regulador no puede abandonar sus conocidas mañas. Órgano oficial de los hombres del gobierno, se imagina que el periodismo está autorizado para pontificar en todos los casos cuando tiene el poder a sus espaldas. Cualquier iniciativa de carácter nacional que surja de las columnas de otro diario lleva, en su concepto, si no el estigma de insano, que es lo que sugiere la interpretación que ha publicado por lo menos un vicio de enunciación que acusa poco estudio y menos criterio al formularla, y gracias que en este caso no haya mostrado las uñas desde la primera línea, pues solamente las deja aparecer en la interpretación final. Velando su espíritu siempre adverso con una cortesía hipócrita, se opone a la idea de realizar la inspección a distancia en la época que hemos indicado, como si no cayera de su peso que, fracasando entonces, sería necesario aprovechar otra.

Lo más abominable del suelto que impugnamos se manifiesta en tono respetuoso, cuando en realidad lo que buscaba era repudiar la sabia interpretación de Nango-Pichango, y con la infatuación que le es propia, arroja como al acaso las expresiones de "exiguo número de letras", "roído documento" - y otras por el estilo, para citar el caso bien conocido de Itis apis, como si no pudiese traducirlo cualquiera que sepa manejar un diccionario grecolatino.

Respecto de la interpretación que propone del "roído documento" no sólo es un absurdo por su contenido sino por la falta absoluta de escuela 
que pone de manifiesto uno de sus “lectores”. ¡Qué falta de ajuste! ¡Qué diferencia con el del original de Ñango-Pichango! Así son los corifeos de nuestra organización vetusta.

Es necesario cepillarle de cuando en cuando los meollos para ponérselos al aire y al día.

$\mathrm{Y}$ cuentos al caso.

Respecto del exiguo número de letras, le recordaremos el caso de Champollion que, al descubrir un solo jeroglífico, la $\mathrm{N}$, pudo leer luego todas las inscripciones egipcias. ${ }^{148}$

Por las perturbaciones de Urano, descubrió Leverrier a Neptuno. 149

A la sola vista de los dos caracteres rúnicos A. S. ya pudo leer el sabio Profesor Otto Lidenbrock, camino del centro de la tierra, el nombre de Arne Sacknussen.

Toda la navegación se debe a una estrella: la polar.

"Dadme un solo punto de apoyo, y hago saltar el mundo" - dijo Arquímedes. 150

Y podríamos citarle otros mil casos al maestro ciruela de El Regulador, para que se convenciera de que un solo hueso de mono en el terreno devónico podría autorizar, por la inducción de un Pichango, la existencia presunta de toda una civilización en el carbonífero.

El Regulador, Agosto 12 de 1913. En los tiempos de la "civilización presunta" del carbonífero, llegó a Monalia sumergida una carta del Continente en la cual se leía lo que sigue:

A pesar de la tranquilidad reinante en la Convención de Molenia, inspirada en los más sanos principios del patriotismo y de la cultura, parece que va a haber rotura de platos entre los periodistas, lo cual sería una verdadera calamidad. Y todo por causa de un indigno rompecabezas hallado en un mamotreto. Las dos interpretaciones publicadas hasta ahora parten de una base que bien podría ser falsa. ¿Por qué no ha de poder estar escrito en latín y no en castellano el documento manzana de discordia?151 Tal es, a lo menos, la opinión de un Pichango que por aquí tenemos, y que lo interpreta así:

148 Jean François Champollion: (1790-1832) francés, creador de la egiptología científica. Descifró muchos de los jeroglíficos egipcios, como así también el modo cómo debían ser leídos. Autor de: L'Égypte sous les Pharaons (1814), Grammaire égyptienne (1836-1841), Dictionnaire égyptien (1842-1843), etcétera.

149 Urbain Jean Joseph Leverrier: (1821-1877) astrónomo francés que por el movimiento de Urano predijo la existencia de Neptuno. El 23 de septiembre de 1846 J. A. Galle, en Berlin, descubrió el planeta Neptuno con una diferencia de un grado con respecto al lugar que Leverrier había indicado (E. B. 13: 1002).

${ }_{150}$ Arquímedes: (¿287-212? a. C.) geómetra, matemático e inventor griego. Descubrió el principio llamado de Arquímedes que determina el peso específico de los cuerpos. Sus inventos en mecánica le hacían decir "Dadme un punto de apoyo y moveré la tierra"; con esto quería significar que poca fuerza puede mover mucho peso (E. B. 2: 297).

151 manzana de discordia: Holmberg alude a la manzana de oro arrojada por Eris, la personificación de la discordia, en la asamblea de las diosas y que Juno, 
Sub-hoc nomine determinare possumus crebrem punctatum orthorhynchum judicatum habitu sectiones gruinarum atque forsan adhuc non descriptum. Alterum ad kalendas Julias in montibus Himalaya repertum satis est conforme et fert apud hispanos nomen alcaraban ${ }^{152}$ de las montañas.

Y como esto también es verosímil, tanto más cuanto que el latín es de cocina, quizá convendría buscar en el Museo de Molenia, entre las zancudas, y en la sección de las grullas (gruinae) la que tenga el plumaje "densamente puntuado", y entonces el mencionado rompecabezas podría no ser sino una nota fugaz de algún naturalista. Seguro que la letra del original, tan única, no puede ser de Teridion Pampelunio.

Por otra parte, y sin menoscabar la compleja erudición del redactor de El Patriota, le recordaremos que, cuando escribía en El Austral, hace unos 15 años, llevó a tal grado los elogios, prodigados a cierto Instituto, fabricó tales hipérboles, alborotó de un modo tan exagerado al público, que los profesores y los alumnos de aquél acabaron por ser unos pedantes tan insoportables que hubo necesidad de enviarlos al Continente donde han hecho camino, porque, de distinta suerte que lo que ocurre en Monalia, allí hay lugar para todos sin distinción de raza ni de aptitud, y es frecuente, como dice un vasco medio rabioso pero de mucho talento, que cuando necesitan un diplomático nombren un bailarín.

¡Qué sorpresa! Tenemos oportunidad, al corregir la prueba, de comunicar a nuestros lectores la noticia de habernos llegado, en este momento tres interpretaciones nuevas: una en francés, otra en italiano y la tercera en inglés.

El Patriota de Agosto 13 de 1913, se ocupó de asuntos económicos y políticos haciendo al latinajo de El Regulador la conspiración del silencio; pero se supo que le había llegado al redactor de aquél un telegrama cifrado de Pitango en el que le recomendaba no se ocupara más de las ruinas ni del rompecabezas. Calmada así la tormenta probable, lo que parecía revelar que Pitango barruntaba los despropósitos en que iba a caer El Patriota, alguien insinuó que Moloso había tomado cartas en la cuestión también. Cierta mañana vieron efectivamente a Moloso entrar en casa de NangoPichango y dirigirse luego ambos, a la oficina en que se había en-

Minerva y Venus querían para sí. Entre las consecuencias de esta discordia figura la guerra de Troya cantada por Homero y Virgilio en La Iliada y La Eneida respectivamente. Por extensión esta expresión indica cualquier asunto que origina desacuerdos o luchas.

152 alcaraván: (Oedicnemus oedicnemus) ave zancuda de plumaje pardo rayado de blanco (M. Moliner, Diccionario del uso del español, 2 vols. [Madrid, Gredos, 1986] s.v.). 
contrado el documento. Una hora después salieron los dos, Pichango con cara de duelo y Moloso riéndose a carcajadas.

En el número del 14 de Agosto, El Regulador publicó un suelto titulado:

\section{Asunto concluido}

Moloso es y ha sido siempre un hombre práctico. No podía explicarse el galimatías originado por la interpretación del rompecabezas de El Patriota que consideraba una fuente fecunda de inútiles discordias ulteriores, tanto menos oportunas cuanto que la Convención está a punto de terminar su cometido. En compañía de Ñango-Pichango buscó el legajo en que se había encontrado el documento en discordia, y ambos convinieron en que se trataba simplemente de una tira de papel colocada como indicador en cierta foja. Esa tira representaba el fragmento de borrador de un informe médico-legal, cuyo texto íntegro se encontraba en el mencionado legajo y precisamente en la página indicada por la tira. El texto íntegro constituía un breve párrafo:

Es muy difícil determinar cómo un hombre tan rico $y$ tan juicioso haya podido caer en ruina. Los unos piensan que sus facultades se encontraban alteradas; los otros opinan que haya quizá confiado demasiado en alguna persona de malas mañas.

De aquî resulta que todos los intérpretes hemos perdido nuestro tiempo practicando agujeros en el aire. Pero esto sirve de fundamento para deducir las monstruosidades a que podrán llegar los paleógrafos de Monalia cuando estudien e interpreten viejos legajos devorados por la polilla.

$$
* * *
$$

Ñango-Pichango y el redactor de El Patriota resolvieron salir al campo, cuando llegara el buen tiempo, para gozar de una breve vacación, eligiendo para su descanso las montañas del poniente desde donde pudieran divisar toda la tierra que quedara al pie, al Noroeste del sitio elegido. Esto demuestra la existencia de cráneos tan tenaces como su propio contenido y la necesidad de triturarlos para modificar su estructura porque la evidencia es inaccesible para ellos. Y demuestra también que muchas veces, para despejar tinieblas que parecen impenetrables, el camino más corto es el más simple: encender una vela.

La Convención, por su parte, estaba a punto de terminar la Constitución de Monalia, y el Gobierno Central, dándose cuenta de que las formas patriarcales son incompatibles con la piratería internacional, solicitó de los convencionales el más absoluto secreto 
para sus decisiones mientras tomaba una serie de medidas con el objeto de colocar a la Nación en condiciones de hacer frente a su próxima representación moderna, una vez que, constituida bajo el imperio de un régimen semejante al de las otras Repúblicas Sudamericanas, tendría que someterse a todas las calamidades que la internacionalidad completa exige de las naciones.

Hija predilecta de la paz y de todos sus beneficios, se extinguiría Monalia como entidad arcaica para convertirse de un golpe en Humanidad moderna ilustrada y progresista a voces. Su bandera blanca con dos diagonales celestes y un anillo de diez estrellas de oro en el centro no podría flamear libremente por tierras y mares sin llevar el latigazo rojo que adorna las de todas las naciones más humanitarias, más cristianas, más honestas, más respetuosas del derecho del más débil cuando nada les produce. Monalia se vería obligada a explotar en grande escala sus minas de hierro y de carbón; se multiplicarían sus astilleros y usinas; y, a la vez que los arados, fundirían las barras de acero con que se forjan las espadas y se construyen los acorazados, los torpederos, los submarinos, sin contar los otros instrumentos con que los pueblos defienden su existencia o luchan por la vida; y los convencionales, dándose cuenta de la transformación fundamental que creaban en su régimen de vida política, juraron guardar el más profundo secreto, declarando que la nueva Constitución no se promulgaría mientras Monalia no estuviera en condiciones de adherirse al Congreso de La Haya, sublime símbolo de paz inventado por Rusia en los momentos en que, ballena hiperbórea, pensaba tragarse a los japoneses como sardinas y se tragó luego su arpón.

En aquellos momentos solemnes en que todos reconocían que en sus manos se apoyaba el porvenir de la patria, se puso de pie Toribio Albarda y una vez que la presidencia le concedió la palabra, dijo:

Señores Convencionales. No necesito reclamar atención especial porque la evidencia no ha menester de reclamos; pero confieso que la emoción y el entusiasmo dominan por completo mi organismo en este instante, en este momento grandioso en que la patria reclama el esfuerzo máximo de sus hijos. Y ese entusiasmo tiene un motivo que pugna por desbordarse y al que daré puerta franca sin más preámbulo.

En el concepto de las naciones, y a pesar de que nuestra nacionalidad se ha constituido por la convergencia de diversas antiquísimas razas, pertenecemos a la latina. De aquí el fenómeno extraordinario que se ha producido en nuestro país, lo que confirma ese concepto. Todo el esfuerzo de 
los oradores anglosajones estriba en la exposición clara, neta y categórica del pensamiento, siquiera sea cuando no se trata de asuntos internacionales; y cuanto más categórica, más neta y más clara sea esa exposición, más rápidamente también se llega a las soluciones deseadas. Nosotros, por el contrario, estamos inhabilitados para seguir ese procedimiento. Necesitamos apoyar, repetir, discutir nuestra propia argumentación para que se nos atienda, se nos escuche y se aprecie nuestro fundamento. No somos aptos para la continuidad de la tarea. Tenemos la versatilidad de los monos sin atención. Monalia quería lo que se está viendo que quiere: modernizarse, hacerse asimilar por el conjunto de las naciones, con todas sus ventajas $\mathrm{e}$ inconvenientes, $y$ ha sido necesario el esfuerzo genial y gigantesco de una grande elocuencia indirecta $y$, al parecer, difusa y loca para que tuviera su sanción la voluntad soberana de los pueblos. Hago moción, Señor Presidente, Señores Convencionales, para que nos pongamos de pie en homenaje a los grandes patriotas ausentes.

\section{XII}

DESCUBRIMIENTO DEL RETRATO DE CACHIMBO PÉREZ Y DE LA ESTATUA DE MAMERTO BOTIJO, PRÓCERES DE MONALIA.

- LOS SECRETOS DE UNA RÚBRICA. - ALGUNAS OPINIONES DEL MINISTRO PITANGO SOBRE BUENOS AIRES

Buenos Aires, Agosto 20 de 1913

Puedes imaginar, querido amigo, a qué grado llega la emoción que me embarga. En nuestra situación política actual, y hecho este descubrimiento, estoy a punto de considerarme un verdadero Colón.

Murió hace pocos años en esta ilustre ciudad un famoso bibliófilo, cuya biblioteca, reunida con la paciencia, prolijidad y astucia de los antiguos escoliastas, contenía verdaderos tesoros en libros viejos y manuscritos. Desgraciadamente hoy se encuentra dispersa, lo que es una calamidad para los historiadores americanos; pero la suerte ha querido protegerme al presentarme la oportunidad de conocer y adquirir la maravillosa pieza cuya fotografía te adjunto, y que se encontraba en aquella. Como ves, se trata de una hoja de papel de hilo, bastante quemada, y que, según me afirman, es lo único que se salvó en 1875 del incendio de la famosa biblioteca del Colegio Nacional de Santiago del Estero, provocado por el canónigo que acababa de ser nombrado rector del mismo, y que aquí se considera un moderno Omar, ${ }^{153}$ cuyas palabras repitió sin más variante que la de Biblia en vez de Korán.

153 Omar I: (581-644) segundo de los califas musulmanes que sucedieron a Mahoma. Defensor del islamismo, guerrero y político, en el 640 conquistó Egipto y mandó destruir la famosa Biblioteca de Alejandría. 
Es imposible que no haya existido en Monalia algún Omar semejante, y ya nos ocuparemos de ese asunto cuando llegue la oportunidad, pues no faltan rastros al respecto, y que te recomiendo desde ahora.

Ese retrato es un prodigio, y como me encuentro en vena de interpretaciones, no puedo resistir a la tentación de comunicarte algunas.

Debo declararte que, en mi concepto, el artista ha sido un verdadero genio, muy especialmente como psicólogo. Observa la noble simetría del conjunto, y dime si no te recuerda esas figuras fantásticas que hacen los muchachos apretando una cabeza de mosca dentro de un papel doblado y junto al pliegue. Ha simbolizado de esta manera la unidad, el equilibrio, la energía, la serena majestad del carácter de Cachimbo, en un cuerpo elegante, esbelto, psíquico, para decirlo todo en una palabra. Y luego, allí donde reside su mayor potencia, la fuente de su nombradía, la prodigiosa, incomparable laurorum genitrix, 154 su cerebro, radiante de vida, de elocuencia variada, motriz incansable y fecunda, el sombrero mismo es afectado por la divina irradiación de su talento, y la pluma se levanta como una llama vigorosa impelida por un aletazo del viento de la gloria. Con los movimientos asimétricos de ambas piezas, se establece un equilibrio artístico incomparable, desaparece la monotonía, y resaltan con más carácter los rasgos agudos y enérgicos del Pericles monalita.

Estudia ahora la rúbrica y observa el movimiento de los rasgos. Obsérvalo bien, Toribio, porque, mientras Ñango-Pichango no haya restaurado las deficiencias de los manuscritos que contienen sus tres discursos, esa rúbrica será el único documento positivo revelador del modus operandi de Cachimbo al modelar sus arengas. Empieza de un modo consecuente con el tema o motivo del discurso, que, en este caso particular estaría representado por el lazo infralinear de la $z$ final. Después de mantenerse por algún tiempo en el exordio derramando su elocuencia en lazos alternativos de ascenso y descenso, como los argumentos en pro y en se expresa en un período águila envolviendo una argumentos que acepta, se que debieron ser una masi presentara a su auditorio contra del caso en cuestión, valiente como el vuelo del parte de los antecedentes y entretiene en modulaciones ravilla de gracia y de voz, regresa a los argumentos para compararlos ahora, vuelve a un intermezzo en que pinta sin duda con soberana elegancia las situaciones probables, y tomando una decisión repentina, fulgurante, plantea un silogismo con una premisa indiscutible representada por el primer triángulo, $y$, una vez entregada la consecuencia a sus oyentes, se expande en amplio vuelo sigmatóideo, ${ }^{155}$

154 laurorum genitrix: madre de los laureles o victorias.

155 sigmatóideo: de sigmatoides (sigma -atos, sigma, y eidos, forma); anat. cavidad en forma de sigma en la apófisis del cúbito (Martín Alonso, Enciclopedia del Idioma, 3 vols. [Madrid, Aguilar, 1958] s.v.). La rúbrica de la firma de Cachimbo Pérez, que aparece en el medio de la página, reproduce la forma de ese del hueso sigmatoides. 
y siguiendo una línea serpentina de altas ondas cual si ofreciera los hechos históricos justificativos de la opinión que defiende, los sintetiza con un vigor extraordinario simbolizado por la línea gruesa; y vuelve, apagando la voz en forma gradual, hasta terminar en un epifonema que abraza su silogismo fundamental expresado ahora con elegantes modulaciones, suaves y apagadas como para que el público sienta que no solicita su aplauso sino la expresión de su raciocinio. Y es un hecho que, a pesar de todo, el público lo aplaudía de una manera frenética, como lo consagra la tradición, que "vale más que los documentos", según afirma un historiador argentino que ha recibido de la Nación 25.000 pesos para publicar un montón de sandeces y de insolencias que le habrían costado muy caras si hubiesen merecido ser leídas.

Como ves, ese retrato ha sido grabado en madera en 1648, es decir, cuando tenía 35 años. Nació por lo tanto en 1613, de modo que no falta mucho para que celebremos el tercer centenario de su nacimiento. Busca en Molenia la fecha en los libros de nacimiento de ese año, y si no existe allí, busca en otros, y envía circulares solicitando el dato a todas las ciudades y pueblos de Monalia que ya existían entonces.

Una vez terminada la obra de la Convención, vente en el primer vapor que salga de Neópolis, si no es que prefieres hacer todo el viaje por mar, embarcándote en Molenia. Aquí ni siquiera se discute tu venida. Tus discursos han despertado tal entusiasmo en los intelectuales de este país, que... imagínate que ya está constituida la Comisión que ha de recibirte. Aunque aquí existen oradores eximios, tienen una preferencia marcada por los exóticos, unas veces porque no los entienden, otras porque son muy galantes con el pueblo, con la Nación. Vino hace algún tiempo un escritor famoso (entrada paga) el cual publicó una carta que se consideró por voz corriente que hubo de ser grabada en colosal placa de oro, y cuando se iba a realizar tan pomposo homenaje, a alguien se le ocurrió que sería mejor leerla primero, porque el citado escritor era uno de los más encumbrados burlones contemporáneos. No se ha fundido ni se fundirá la placa de oro.

Con el afecto de siempre, mi caro Toribio

Olimpio Pitango

Molenia, Septiembre 5 de 1913

Ilustre amigo y caro maestro:

Lo que a ti no se te ocurre, nadie lo sospecha siquiera. Te escribo bajo la influencia del estupor más grande que pudieras imaginar. Al leer tu carta examiné la rúbrica de Cachimbo Pérez, guiado por tus indicaciones, y jasómbrate Olimpio! Como en la Convención se trataría del divorcio al día siguiente, esbocé un discurso en concordancia con la forma oratoria que señala tu interpretación. Al pronunciarlo, me han aplaudido de tal manera, ha habido un estrépito tan colosal, los comentarios y las felicita- 
ciones han alborotado de tal modo a esta gente, que fue necesario postergar la sesión. Al entrar esta mañana en el recinto, se han repetido los ; bra$v o$ ! y los aplausos durante un cuarto de hora. Ni se discute ya el tema, pues ha sido aceptado por unanimidad. Por otra parte, mi argumento fundamental fue el de la aptitud, base de la estructura física, intelectual, moral y social de Monalia. Aquí no se realiza un matrimonio sin determinar previamente si los futuros cónyuges son aptos en todo sentido, individual y recíprocamente. Resuelto este punto, el divorcio no tiene probabilidades. Creo que por ahora no conviene publicar tu carta, pues, si se dan cuenta del artificio, no sabemos lo que podrá suceder. ¿No te parece? Si esto ha sido un triunfo, a ti lo debo. Un gato legítimo no muestra las uñas, sino al arañar, iy aún así!

Pasemos a otra cosa.

Me toca a mí darte una sorpresa.

Ha llegado de Europa un extranjero que trae un cargamento de libros. El Gobierno Central le pidió el catálogo, el cual se pasó al director de la Biblioteca Nacional. Se le ha comprado un centenar de obras raras que faltaban aquí.

No, Olimpio; no. Si en una de ellas estuviese la página en que estás pensando, te lo habría dicho antes de escribir la fecha - más aún: por telégrafo.

Además de los libros, trae varias carpetas con estampas nuevas y viejas, en negro o coloreadas, y se me ocurrió revisar algunas. Entre otros muchos papeles viejos, encontré una hoja quemada, exactamente de la misma forma que la de la fotografiada que me enviaste; pero de doble tamaño, y los contornos de la parte carbonizada son tan idénticos que, si no fuera por las dimensiones, se podría afirmar que estaban juntas cuando se quemaron.

—Claro, clarísimo que estaban juntas! —exclamó Pitango al llegar a esta parte de la carta de Toribio-y ordenó se le hiciera un telegrama a Molenia diciéndole que la fotografiada estaba reducida a la mitad.

Todo me hace pensar que la fotografía adjunta (reducida a la mitad) sea para ti una gran sorpresa. El original es de un grabado en cobre, $y$ he podido leer Rup... Botixo. Ñango-Pichango me dice que Botijo se llamaba Ruperto. Pero esto es una estatua.

A lo lejos se ve el Monte del Cabo y, dato lleno de interés, el dibujante ha señalado junto a él el Montículo del Sudeste. En esa relación de posiciones, sólo puede verse así el montículo desde el Nornoreste de Molenia. Siguiendo esa línea, he deducido que la estatua debió levantarse en la Plaza del Año Nuevo, y, como no hay nada en su centro, se me ocurrió que pudo encontrarse en él. Llevé trabajadores, y a poco de iniciar una excavación encontramos un cimiento cuadrado de piedras graníticas, orientado a los cuatro vientos, como lo revela el grabado. Después de mucho trabajo con- 
seguimos descubrir el pie derecho con parte de la pierna, de una identidad absoluta con el dibujo. Es de mármol. Nadie sabe nada al respecto, y por lo mismo todo el mundo opina algo. Me dice un químico que, si ha sido destruida con fines industriales, dado el peso molecular del mármol, debe haber producido más de cinco toneladas de cal viva. Era realmente un Botijón. Cuando se ejecutó el dibujo, ya estaba muy obliterada la inscripción del pedestal. Parece, sin embargo, que era latina. Puede leerse en el grabado: “...e Monalia... agis (m)agno... tixo" - lo que podría dejar monumentalmente consagrado que, cuando se le erigió esa estatua (quizá en vida), ya se le designaba como "Gran Botijo", pues está claro que Magno Botixo se encuentra en dativo y es de dedicatoria.

El negociante ha ganado más con este documento que con los libros, pues me ha costado el papelito la friolera de 400 libras esterlinas, y eso que pedía 500 . No importa. Bien vale la pena hacer este pequeño sacrificio en homenaje al prócer.

Un fuerte apretón de manos de tu afectuoso amigo

Toribio Albarda

Buenos Aires, Septiembre 9 de 1913

Querido Toribio:

En medio del gran placer que me causa la adquisición que has hecho y los descubrimientos que con tanta sagacidad has realizado, no puedo ocultarte que me aflige en extremo una coincidencia. También pagué yo 400 libras por el papel quemado que poseo, y el vendedor me pidió 500 . Necesito que me describas el tipo de ese individuo y me comuniques todos los datos relacionados con él: altura, color, pelo, idioma y acento. Si recuerdas L'Immortel de Daudet, no habrás olvidado al personaje aquel que vendía a Astier documentos históricos. ${ }^{156}$ Todos los bibliófilos que he consultado aquí, algunos de ellos papyrognostas 157 muy hábiles, están de acuerdo en que ese papel de hilo es realmente de principios o mediados del siglo XVII, en que la impresión y carácter del grabado no desdicen con algunos de esa época, aunque a todos nos asombra que el fondo no está

156 L'Immortel (1890): novela del autor francés Alphonse Daudet (18401897). En ella se describe el mundo de intrigas y de maquinaciones de la Academia Francesa. El personaje principal es un investigador, Paul Astier-Rhéu, que es elegido académico o "inmortal", como son llamados los miembros de la Academia. Astier cae en manos de un falsificador que le vende cartas autógrafas y documentos falsos. Él y la Academia son ridiculizados y a consecuencia de esto Astier se suicida.

157 papyrognostas: neologismo de Holmberg, amantes del papel (pápyros), formado con la etimología griega de papel. 
rayado; pero tú sabes que en esos libros viejos solían agregar una o más hojas en blanco, y has de saber también que, al visitar al Doctor X me hizo ver un volumen en $4^{\circ}$ de 1650 , y encontró, con bastante sorpresa, que le habian arrancado precisamente dos de esas hojas que antes no le faltaban. Cuando nos veamos estudiaremos este punto.

Nada me dices de una curiosidad que se observa en la espada recta pendiente del tahalí que lleva Botijo: la ondulación de los bordes. Si hubiera ... no me animo a escribirlo... bueno: si hubiera una falsificación, no se puede negar que el falsificador tenía talento. Ruperto (efectivamente, así se llamaba), Ruperto Botijo, o Botixo, como se escribía en su tiempo, tenía una voz estentórea, y vibrante. En el grabado se ve que está hablando; - y mira qué rasgo: la vibración de la voz se transmite a la espada y la hace ondular.

He leído tu discurso, y su estructura es efectivamente la misma de la rúbrica de Cachimbo Pérez. ¡Cuánto siento no habértelo oído! Pero ya me lo leerás. No es dudoso, sin embargo, que le llevas una gran ventaja: tu voz es más sonora, más metálica, más vibrante; la de él era más débil. Estudiando su retrato, he mandado hacer al óleo uno de perfil - y éste será el que consagraremos.

Me colmas de elogios en tu recuerdo, consignado con motivo de las felicitaciones: "Agradezco sinceramente el alto homenaje que ustedes me dispensan; pero no olviden que, si poseo alguna habilidad oratoria la debo al ilustre maestro ausente, al Gran Olimpio etc., etc.". - No; tú no me debes nada. Ya te lo dije: eres un Demóstenes, Toribio.

Estos argentinos de Buenos Aires, porteños, como se llaman ellos (y la verdad es que en Monalia la mayor parte de la población es porteña, como que todas nuestras ciudades son puertos), son muy burlones. En cuanto oyen un apellido al que no están acostumbrados, y con esa amable trivialidad que los caracteriza, se desatan en improperios humoristicos, como si les hicieran cosquillas en los departamentos de la imaginación. El otro día me han hecho enojar - ya sabes la cara que pongo cuando me enojo- y tuve que hacerles algunas observaciones pesadas, diciéndoles que había algunos apellidos ridículos que eran un honor para la nación que los contenía, y en cambio otros, muy distinguidos, que pesaban como una pirámide de plomo patriótico sobre las personas y las cosas. Les di algunos ejemplos locales, y no puedo afirmar que quedaron contentos. A pesar de que convinimos en que muchos de duración secular se amoldaban perfectamente a la naturaleza de las personas, el tono general era más bien agrio. Como son muy aficionados a arreglar ciertos asuntos por intermedio de otras personas, lo habría pasado mal si no me hubiesen visto con anticipación desenvolverme con cierta soltura de maestro en los clubes en que se hace esgrima, o se pintan 9 moscas y 1 mosquito en 10 tiros a 20 pasos y a pistola. Por lo demás tienen un carácter delicioso. La cantidad de intelectuales es asombrosa. Pero lo que me ha dejado lleno de estupor es el arte soberano de algunos brutos para codearse con desenvoltura entre esos in- 
telectuales. Esto no lo conocemos nosotros en Monalia, donde el que sale bruto lo es de verdad, consecuencia y colocación. Como los monalitas somos tan serios en todos nuestros asuntos, me causa malestar cierta superficialidad que no siempre es legítima. Pero lo más curioso es que le juegan risa a las cuestiones más graves, y más curioso aún el hecho de que, con risa y todo, les salen bien. Cuando se dedican a los negocios, te hablan de una diferencia posible de 2 o 3 millones más o menos, como si se tratara de centavos, y esto lo atribuyo al abuso del juego en todas sus formas. Aquí se gana el dinero con tanta facilidad, que hoy te encuentras con muchos potentados que hace pocos años carecían de zapatos.

La fácil asimilación ultra-democrática del proletariado enriquecido con las familias patricias es un fenómeno complejo del cual me ocuparé en alguna de mis cartas ulteriores, porque se trata de algo muy interesante desde un punto de vista sociológico, aunque por suerte no tiene aplicación en Monalia donde, si bien es cierto que triunfan los más aptos, jamás se ha llegado a adquirir la fortuna sin aptitudes superiores por su naturaleza.

La misma facilidad con que se produce la fortuna origina en ciertos casos, relativamente comunes, y tanto individuales como colectivos, un despilfarro de consecuencias inevitables; pero es tan grande la potencia económica del país que, en estos momentos, y a pesar de los 200 millones gastados en la celebración del centenario (según me dicen), no se sabe de un modo positivo si existe actualmente o no crisis económica, así es que, para ocuparse de algo indiscutible, los hombres dirigentes procuran dedicar la mayor atención al abaratamiento de la vida.

Aquí todo es caro, porque la especulación es muy impaciente y los economistas por lecturas muy abundantes. Todas las administraciones son muy papeleras, y más que de los asuntos fundamentales se ocupan de la forma. Tal jefe de oficina devuelve una nota que contiene una materia vital porque el que la subscribe ha escrito al fin "Saluda a Ud. con toda consideración" en vez de decir "Dios guarde a usted muchos años", o porque en vez de consignar "Saluda a Ud. muy atentamente" le ha suprimido el muy por voluntad $\mathrm{u}$ olvido.

Si se necesita hacer un gasto de dos pesos para comprar con urgencia cierto tornillo de una máquina cuyo funcionamiento no puede ni debe retardarse dos horas, la nota del pedido tramitará por veinte oficinas durante quince días o un mes. Todos alborotan, todos gritan, todos protestan, y el expediente sigue su marcha o no. Si se le encuentra un defecto en la tramitación, máquina atrás, y venga como corresponde, y siga marchando, y cuando en el andar de los días llega la deseada autorización, nadie sabe de qué se trata, porque otra oficina de acción concomitante ha cambiado la máquina, los operarios son otros y todos ignoran para qué puede servir ese tornillo. En unas oficinas, los empleados toman aires de perros rabiosos porque un interesado va a preguntarles cómo anda su expediente y le contestan de mal modo que no necesitan lecciones para el cumplimiento de sus deberes (relativos al té o al café) -y en otra de gran ca- 
tegoría, a la cual no va el interesado porque supone que allí conocen su deber, le contestan que el asunto está olvidado porque no se ocupó de moverlo.

Por un empleado prevaricante que se castiga quedan doscientos absolutamente impunes; pero los libros están muy bien llevados desde un punto de vista estético y la documentación justificativa es admirable. La instrucción pública es muy barata y obligatoria, y los hombres más ilustrados del país piensan que solamente los analfabetos son los pícaros, aunque parece que muchos grandes bribones hubieran podido ilustrar a Pestalozzi158 y a Pico de la Mirándola. 159

¡Abaratamiento de la vida!

Por una razón o por otra se crea un nuevo impuesto mercatorio de 1 peso por cada animal vacuno que sale del matadero, y que le cuesta 100 pesos al beneficiante. En vista de "tan monstruosa exacción", de tal iniquidad, no se mira que el costo se ha aumentado en 1 por ciento - lo único que se ve es que se ha aumentado, y los trozos que antes de dicho impuesto se vendían por 50 centavos, ahora se venden a $75-$ y es curioso que estos aumentos de 50 por ciento en la venta, cuando el aumento del costo es de 1 por ciento, no se tomen en consideración en ninguna parte ostensible y sólo se traduzca por el grito unánime que reclama contra lo caro de la vida.

Una cabeza de repollo te cuesta 20 centavos en el mercado. El cultivador la había vendido por 2 , es decir, hay un aumento de 900 por ciento. ¿Te quejas? Te contestan tranquilamente: - "Si no le conviene no la compre."

Como tú no has salido aún de Monalia donde los suburbios de todas las ciudades son jardines de verduras y de flores, donde no falta nada para el bienestar de la población, no puedes imaginarte la impresión penosa que causan los alrededores de esta gran capital con 1 millón y medio de habitantes. Están constituidos por campos de pastoreo para vacas lecheras donde los animales comen lo que encuentran y en los que la acumulación de los mismos es mucho mayor que la proporción de 1 o 2 animales por hectárea. Pero, me dirás, ¿es posible que todos los terrenos estén ocupados por vacas? Sí; todos los que tienen una extensión suficiente como para contener el número de cabezas que conviene al tambero. ¿Y los que no les convienen? Un buen cultivador puede hacer mucho en terrenos relativamente pequeños. Es verdad; pero esos están subiendo, se están valorizando, y los propietarios no los quieren arrendar porque necesitan tenerlos disponibles en el momento preciso en que les convenga el precio de venta. Aquí los latifundios son incontables, y los propietarios pagan impuesto de pro-

158 Johann Heinrich Pestalozzi: (1726-1827) educador suizo que propició numerosas reformas sociales, morales y políticas. Sus principios fueron elaborados en su libro Cómo enseña Gertrudis a sus niños (1801). Creó una escuela modelo en Iverdon, cuya metodología fue imitada por educadores europeos y americanos.

159 Giovanni Pico de la Mirándola: (1463-1494) filósofo y erudito italiano, exponente del platonismo renacentista. 
ducción, por más que sean pelados o vacíos. Para el fisco, en muchos casos, sería muchísimo más ventajoso cobrar impuestos por la no producción. En la Provincia de Buenos Aires, cuyas tierras son riquísimas, los municipios sólo se ocupan de la parte urbana. Buenos pavimentos, luz eléctrica, vigilancia más o menos completa etc., etc., y la parte rural que se las arregle como pueda. Dada la composición del suelo, los caminos son un desastre en época de grandes lluvias, y de aquí resulta que los productos hortícolas, cuando a ellos se dedican, sólo se cultivan lo más cerca posible de las poblaciones consumidoras, menos en los alrededores de la capital donde los terrenos sólo sirven para la especulación permanente.

Hay otro factor muy interesante. En una de las giras que he realizado hasta algunas leguas de distancia de ésta mi sede ministerial momentánea, llegué a una casi ciudad. Penetré en un hotel, sin duda el más central y mejor, y me senté a almorzar. Me sirvieron carne en todas formas, y al pedir legumbres más variadas, porque sólo me habían servido papas del tamaño de cerezas, me dijeron que no había. - “¿Cómo no ha de haber, si todos los alrededores son quintas de verduras?"- "Es cierto, señor; pero esas ya pertenecen a los acaparadores que las adquieren con premura, las llevan a la capital, surten a los hoteles, a los innumerables buques que salen diariamente del puerto, a los trenes y hasta las envían a ciudades distantes que no las tienen, como por ejemplo Bahía Blanca. Esas mismas papas que Ud. ha comido han sido traídas de Buenos Aires, a donde las habrán llevado de Mar del Plata y hasta de Europa..."

¿Y qué me dices de la fruta? En verano, que es cuando más se necesita, no la hay. Los acaparadores la compran por mayor y la conservan en cámaras heladas hasta el invierno. Entonces te venden la docena de duraznos por 3, 4 o 5 pesos - “y si no le conviene no los compre". A esto se agrega el enorme consumo de fruta para conservar en tarros y enviar a Europa, lo cual no impide que vengan cargamentos de Europa, de Estados Unidos, de Australia y de otros países de Sud América.

Es indudable, sin embargo, que lo que aumenta en mayor escala el precio de los consumos es el número de intermediarios que separa al consumidor del productor. Se ha hecho mucho ruido a propósito de las ferias francas; pero, ni son tan frecuentes ni tan numerosas a la vez, y en muchos casos podría preguntarse si el abaratamiento de la mercancía no se debe en gran parte a su calidad inferior, como sucede con la carne. Donde he visto productos de primer orden en tales ferias ha sido en La Plata.

Pero la carestía de la carne en este pueblo esencialmente carnívoro, se debe también a una escasez creciente relativa, que aumentará luego de un modo considerable debido a la impaciencia por la ganancia ya segura, que mata sin distinción, para responder a las exportaciones, las vacas y los bueyes, sin tener en cuenta que el sacrificio de las primeras implica la merma en la producción. La mejor del país va para los mercados europeos especialmente Inglaterra y ahora hay que pensar en las modificaciones de régimen alimenticio de los japoneses y las muy probables en la China re- 
publicana. (Debo abrir, Toribio, aquí, un pequeño paréntesis. Si tuvieras la mala idea de publicar esta carta en Monalia, debes hacer notar que aquí se justifica el sacrificio de las vacas porque a cierta edad ya no deben producir, y el de las vacas jóvenes, porque se llaman terneras, vaquillonas, etc. y no llevan el nombre de vacas).

El consumo de animales ovinos es relativamente menor que en otro tiempo, porque se va perdiendo el gusto por ellos debido al predominio del carnero Lincoln que da más carne, pero inferior a la de las otras razas que antes se consumían...

No se preocupan aquí mayormente de la cría del conejo, quizá una de las más productivas (relativamente) y más baratas, si se considera su alimentación y la rapidez del crecimiento. Se dice que su carne es insípida; pero esto es absurdo, porque aquí toda la carne lo es. ¿Y cómo no ha de serlo, si en general no saben o no quieren condimentar los alimentos?... La liebre europea, que se ha propagado aquí hasta convertirse en una plaga, no es apreciada ni por los europeos. "Es insípida". Claro está, y eso porque los pastos naturales lo son. La liebre no encuentra aquí la abundancia de condimentos aromáticos que existen en las praderas de Europa: el tomillo, las mentas, el toronjil o melisa y tantas otras hierbas; no encuentran muchas veces sino virutas sin sabor y sin olor, como los llamados "pastos fuertes o duros", y los dueños de alfalfares las persiguen a muerte y sin misericordia, sin prestar atención al hecho de que la alfalfa les da el sabor que las hierbas restantes no les comunican. (Cómo se reirían los argentinos si leyeran esto, particularmente los que tienen alfalfares. Lo menos que dirían sería: A pesar de que la designa como "plaga" se ve que este Don Olimpio no sabe la cantidad de alfalfa que consumen mil o dos mil liebres en un campo).

Las plagas de insectos aumentan de un modo considerable, porque las leyes y decretos relativos a la caza no se cumplen. La polenta es insaciable y todo cae bajo los tiros, sin exceptuar las golondrinas, los benteveos, los horneros, los churrinches, las tijeretas, las ratonas, las calandrias y muchas otras avecillas insectívoras. El bicho moro hace tabla rasa de los tomates y de las papas, y los sapos que lo persiguen son violentamente asesinados por los muchachos o por todos los ignorantes que los consideran dañinos, o se exportan en grandes cantidades para que vayan a prestar sus servicios en jardines de países donde saben apreciarlos; las orugas de la mariposa blanca destrozan las coles, porque ya va desapareciendo la ratona o tacuarita que es uno de sus mayores enemigos; los crisomélidos destruyen los ajíes y zapallos por la misma causa, y el bicho de cesto se propaga más que nunca, porque su perseguidor más implacable, el benteveo, tiende a desaparecer en estas comarcas. Ya no se oyen teruteros hasta muchas leguas de Buenos Aires, la lechuza de las vizcacheras, azote de los ratones de campo, se mata por ser ave de mal agüero, lo que no impide que figure en los morrales, y que frita o saltada pierda toda su agüería. Se ha dictado recientemente un decreto muy juicioso por la selección de los animales que pueden matarse, y los que deben respetarse; pero una vez el cazador con la 
escopeta en mano, mientras su perro persigue una liebre, mata de paso cuanto encuentra a tiro para aprovechar el tiempo.

Unos pocos ejemplos de ejecución de las multas tendrían mucha resonancia. Pero las multas no son eficaces cuando son excesivas. El despojo de la escopeta sólo debería efectuarse por reincidencia. Una multa moderada haría roncha y propaganda entre los cazadores, y en la imposibilidad de cumplirla una breve prisión con trabajo equitativamente distribuido. La revisión de los morrales en los trenes y una multa de 2 pesos por cada pajarito resguardado por la ley, más el decomiso del resto, daría resultados muy rápidos y eficaces...

Sea lo que fuere. Cuanto te he dicho respecto del abaratamiento de la vida tropieza con lo que aquí se halla instituido como "Libertad de comercio". Esta clase de libertad lleva a todos los abusos, y, como postre te voy a transcribir un caso referido por uno de los hombres más espirituales de este país, a quien se lo he oído.

Cuenta A. L. que, siendo él muchacho, existía en su barrio la pulpería de un genovés, el cual llegó a un grado de fortuna suficiente como para retirarse del comercio, cuya máxima entrada le había sido proporcionada por la venta de vino. Viejo ya, y en su retiro, fue visitado por dos jóvenes porteños de antigua familia que pensaban dedicarse a los negocios, pero que no querían iniciarlos sin conocer los procedimientos del viejo pulpero. Lo fueron a ver; los recibió muy bien, y después de una breve conversación trivial y muchos elogios le preguntaron cuál era el modo de preparar los vinos. - "Ma, il vin si prepara de cuarque cosa, de cuarque cosa... anque al úrtimo con l'uva." Si quieres proteger a algunos labradores de Monalia, explícales cómo la ciudad de Buenos Aires es un maravilloso Gargantúa. Sin tiempo de leer lo que te escribo te envío un fuerte apretón de manos

Olimpio Pitango

\section{XIII}

\section{LAS MUJERES DE MONALIA A LOS MIEMBROS DE LA CONVENCIÓN CONSTITUYENTE. - CIEN VOLÚMENES DE FIRMAS. - OLIMPIO PITANGO ES LLAMADO A MONALIA. - SU RECEPCIÓN. - SI VIS PACEM PARA BELLUM. - PITANGO EMBAJADOR}

Uno de los hechos más conspicuos de la Historia de Monalia es la influencia decisiva que las mujeres han tenido siempre en el desenvolvimiento social, económico y político de la Nación. Educadas a la par que el hombre, sin más diferencia que lo que corresponde a cada uno de los sexos, hemos podido terciar siempre sin desdoro en las deliberaciones de nuestros padres, maridos, hermanos e hijos, y más de una vez han prevalecido nuestras opiniones, aunque éstas fueran conocidas por la Nación, después de los debates públicos de los hombres. 
Nuestros hogares han sido siempre santuarios inolvidables de la patria, donde los niños han aprendido, desde la más tierna edad, los principios de la moral y de la virtud, y donde, fortificados por el ejemplo, han sabido comprender, desde muy temprano, que la prédica del amor a la Humanidad es una colosal mistificación cuando él no radica en el amor a la patria.

Si la prosperidad inalterable de Monalia se debe, en el concepto de todos los ciudadanos y de todas las naciones a la selección y empleo de las aptitudes ¿cuál es el monalita que ha dado sus primeros pasos en la vida común que no haya salido del hogar con su aptitud personal bien definida y altamente desenvuelta?

El más famoso de todos, por el consenso universal, es hoy el Doctor Olimpio Pitango, la inteligencia más poderosa por su plasticidad extraordinaria, por la facilidad maravillosa con que se ha desenvuelto siempre al adaptarse a las variadas situaciones o actuaciones de su vida pública. Mientras su padre conquistaba en todas partes el aplauso de los más competentes por sus conocimientos jurídicos, la madre del niño Olimpio, conocedora de la energía de su hijo para desentrañar los principios fundamentales de justicia natural en los problemas sucesivamente más complicados que se le presentaban, y observando las formas oratorias con que expresaba sus opiniones, desde las suavidades convincentes de un Gladstone ${ }^{160}$ hasta las fulguraciones casi místicas del dominio imperioso de un O'Connell,161 le llenaba la mesa de estudio con las obras de Plutarco, ${ }^{162}$ de Xenofonte, ${ }^{163}$ de Voltaire, de Cormenin, de Pelletan ${ }^{164}$ y de Herbert Spencer. ${ }^{165}$

160 William Ewart Gladstone: (1809-1898) uno de los grandes políticos ingleses del siglo XIX, fue cuatro veces primer ministro. Conocido orador, mejoró la situación de Irlanda y del sistema electoral, estableció el librecambio y trabajó en favor de los sindicatos.

161 Daniel O’Connell: (1775-1847) líder político irlandés, uno de los grandes parlamentarios del siglo XIX, conocido como el Libertador.

162 Plutarco: (¿46-120?) biografista e historiador griego, famoso por su obra Vidas Paralelas, colección de 46 biografías de importantes figuras griegas y romanas. Los otros escritos de Plutarco, cerca de 60 tratados de diferente orden, se agrupan bajo el nombre de Obras morales.

163 Xenofonte: ( $₫ 430-355$ ? a.C.) historiador y escritor griego, fue el representante del estilo ático, revivido e imitado durante el período romano. Autor de Anábasis, Helénica, Memorabilia, Apología de Sócrates, etcétera.

164 Pelletan: probablemente aluda a Pierre Clément Eugéne Pelletan (18131884) político y escritor francés. En su libro Profession de foi du XIX siècle (1852), expuso una nueva teoría acerca del progreso. Otras obras: Histoire des trois journées de février 1848 (1848), Les Droits de l'homme (1858), Décadence de la monarchie française (1860). (La Grande Encylopédie, 21 vols. [París, Larousse, 1971-1978]).

165 Herbert Spencer: (1820-1903) filósofo inglés defensor de la visión científica del mundo en desmedro de la sobrenatural, fue el profeta del evolucionismo y del progreso. 
Ciprio Potante, nuestro gran geólogo, abandonaba a los diez años la lectura encantadora de las Mil y una noches para devorar materialmente las producciones de Lyell, ${ }^{166}$ de Brongniart, ${ }^{167}$ de Élie de Beaumont ${ }^{168}$ y de D’Orbigny, ${ }^{169}$ junto con las de Haüy, ${ }^{170}$ Bergman, ${ }^{171}$ Dufrénoy, ${ }^{172}$ Kengott ${ }^{173}$ y Naumann, ${ }^{174}$ regalos maternos todos, que, ampliados por estudios más extensos ya que no más profundos, le permitían publicar a los 20 años la Gea de Monalia, obra citada con elogio por todos los especialistas del mundo como trabajo insuperable de sagacidad, competencia y exactitud.

Terpinio Cloro, filósofo y botánico que, como Linneo, 175 lloraba desconsolado a los nueve meses hasta que le daban una flor, prefiriendo estos

166 Sir Charles Lyell: (1797-1875) geólogo inglés, autor de Elementos de Geologia, Principios de Geología. En su tercera obra La antigüedad del hombre (1863), apoya la teoría de Darwin sobre el origen de las especies.

${ }^{167}$ Alexandre Brongniart: (1770-1847), geólogo francés, director de la fábrica de porcelana Sèvres, que descubrió la composición de la cerámica. Su obra clásica fue Tratado de las artes cerámicas (1844).

168 Élie de Beaumont: (1798-1874) geólogo francés quien preparó con Dufrénoy el gran mapa geológico de Francia.

169 Alcide Dessalines D’Orbigny: (1802-1857) paleontólogo francés que con Charles Darwin inició el estudio de los fósiles de los mamíferos. Se lo considera el padre de la micropaleontología. Publicó en 1839-1842 Voyage dans l'Amérique Méridionale (E. B. 16: 1034).

170 René Just Haüy: (1743-1822) mineralogista francés, uno de los creadores de la cristalografía. Publicó en 1801 Tratado de mineralogía y en 1822 Tratado de cristalografia.

171 Torbern Olof Bergman: (1735-1784) naturalista y químico suizo que introdujo importantes mejoras en el método de análisis químico, mineralógico, geológico y cristalográfico. En 1766 publicó Descripción física de la tierra (E. B. 3: 505).

172 Dufrénoy, Ours-Pierre-Armand: (1792-1857) geólogo y minerólogo francés. Con Élie de Beaumont y bajo la dirección de Villiers, trazaron el primer mapa geológico moderno de Francia. Es el autor de la importante obra de mineralogía, Traité de minerálogie (Dictionary of Scientific Biography, s.v.).

173 Gustav Adolf Kenngott: (1818-1897) petrólogo, minerólogo y cristalógrafo austríaco. Autor de Die Mineral de Scweiz (1866) y de numerosos artículos sobre los minerales austríacos (William Antony Sarjeant, Geologists and the History of Geology. An International Bibliography from the Origins to 1978, 5 vols. [Melbourne, F. L., Krieger Pub. Co., 1980] s.v.).

174 Karl Friedrich Naumann: (1797-1873) geólogo y minerólogo alemán. Su libro Lehrbuch der Geognosie (1850-1854) fue la obra más importante de petrografía durante el siglo XIX, y la que contiene toda la información científica conocida sobre los terremotos (Dictionary of Scientific Biography. Charles Coulston Gillispie Ed. [N. Y., Charles Scribner's Sons, 1976], 18 vols. s.v.)

175 Carl von Lintué: (Carlos de Linneo, 1707-1778) botánico sueco, el primero en enunciar los principios para definir los géneros y las especies y en usar un sistema de binomio para nombrar plantas y animales. Publicó en 1735 Systema Naturae, en 1737 Genera Plantarum y en 1753 Species Plantarum (E. B. 14: 80). 
delicados caprichos de la naturaleza a los mejores caramelos y mamaderas, fue dirigido por la solicitud y competencia maternal durante una parte de sus exploraciones en el valle y en las montañas, como lo había sido en la interpretación de los textos latinos de De Candolle, ${ }^{176}$ de Bentham ${ }^{177}$ y Hooker, ${ }^{178}$ de Endlicher, ${ }^{179}$ de Willdenow, ${ }^{180}$ de Linneo, de Jussieu ${ }^{181}$ y de tantos otros botánicos ilustres, dando a luz a los 23 años la Flora Monálica, un verdadero monumento de prolijidad descriptiva, de método en la exposición, de gracia y minuciosidad en las ilustraciones, sin que hayan podido agregarle los investigadores que le han seguido otra cosa que algunos hongos microscópicos y algas ocasionales, traídas quizá de lejanos mares, a nuestras costas, enredadas en los anatifes adheridos a los cascos de los buques.

En iguales circunstancias se encuentra nuestro gran geólogo Teridión Pampelunio con su Fauna Monálica, solamente comparable con la Flora de Terpinio Cloro.

Podríamos recordar, Señores Convencionales, además de los grandes físicos y químicos que ilustran los institutos superiores de enseñanza de este país, desde los meleagrinos ${ }^{182}$ hasta los universitarios, los grandes prosistas y poetas que el mundo acoge con grandioso aplauso, para no mencionar a los matemáticos que, con el ilustre astrónomo Saturno Homizo fundador del meridiano de Molenia a la cabeza, y los geógrafos que han levantado

176 Agustin Pyrame De Candolle: (1778-1841) botánico suizo que estableció un sistema natural de clasificación de las plantas florales opuesto al "artificial" de Linneo. Sus obras más famosas fueron Regni vegetabilis systema naturale, Prodromus systematis naturalis regni vegetabilis (E. B. 4: 782).

177 George Bentham: (1800-1884) botánico inglés catalogador de plantas, autor en 1858 de Handbook of the British Flora (E. B. 3: 484).

178 Sir William Jackson Hooker: (1785-1865) botánico inglés famoso por los trabajos realizados como director del Jardín Botánico Real de Kew. Autor de numerosas obras, entre ellas, Exotic Flora (1822-1827) Flora Borealis Americana (18291840) (E. B. 11: 671).

179 Stephan Ladislaus Endlicher: (1804-1849) botánico austríaco conocido por la creación de un esquema de clasificación de plantas publicado en $183 \epsilon$ en Genera Plantarum (E. B. 8: 378).

180 Karl Ludwig Willdenow: (1765-1812) botánico alemán; en su obra Grundriss der Kräuterkunde (1792) desarrolla la concepción de una botánica histórica (Dictionary of Scientific Biography, s.v.).

181 Jussieu: apellido de una familia francesa que se distinguió por ser la mayoría botánicos: Antoine de Jussieu (1686-1758), Bernard de Jussieu (1699. 1777), Joseph de Jussieu (1704-1779), Antoine Laurent de Jussieu (1748-1836), Adrien Laurent Henri de Jussieu (1797-1853) (E. B. 13: 161).

182 meleagrinos: de meleagrinas (meleagro, género de aves gallináceas) f. pl. Zool. Aves gallináceas de la familia de las fasiánidas que comprende un solo género, el del pavo común (Martín Alonso, Enciclopedia del idioma, s.v.). Holmberg con la expresión "desde los meleagrinos hasta los universitarios", probablemente se refiera a los niños pequeños, a los párvulos. 
el mapa geodésico de Monalia cierran la brillante cohorte con nuestros ingenieros y mecánicos entre los cuales, para no citar sino aquellos cuya obra es políticamente ostensible, se destacan los de ferrocarriles que han creado modelos para la misma Inglaterra y para los norteamericanos.

No olvidemos que en un momento solemne envió la Francia enlutada ${ }^{183}$ por el 70 sus mejores pedagogos a estudiar las escuelas de Alemania y su veredicto será perdurable: "No son los ejércitos germánicos los que nos han vencido sino los maestros de escuela y las madres de familia de Alemania."184

Dos grandes hombres, representantes genuinos de estas dos últimas naciones, debieron su grandeza a la dirección materna y a su talento: Jorge Cuvier ${ }^{185}$ y Alejandro Humboldt, ${ }^{186}$ y con ellos podríamos citar pléyades de varones ilustres cuya celebridad tuvo igual origen.

$\mathrm{Y}$ si es un hecho evidente cuanto al respecto se vincula con Monalia ¿para qué arrancarnos de nuestros dominios domésticos?; ¿ por qué motivo ha de empeñarse la Convención en equipararnos con los hombres sometiéndonos a todas las molestias que implican los actos electorales, por más rápidos que sean en este país?; ¿por qué ha de disminuirse nuestro prestigio negando la influencia definitiva que ejercemos en los miembros masculinos de nuestras familias exponiéndonos en caso de disidencia a ganarles una elección ostensible cuando las tenemos siempre ganadas con sólo quererlo, y fomentando así la discordia que sería la ruina de todos?

Por otra parte, las funciones políticas distraerían, debilitándola, nuestra función educadora.

¿Qué efecto produciría en los niños que la Naturaleza y la Patria nos confían la contemplación de escenas de discordia, cuando nuestra principal tarea debe ser constante para despertar en sus tiernos corazones los más altos sentimientos de amor y de prudencia?

183 la Francia enlutada: alude a la desastrosa guerra para los franceses con Prusia (1870-1871), declarada por Napoleón III, en ella los prusianos le imponen a los franceses el Tratado de Francfort (1871).

184 Después de la guerra Franco-Prusiana, los franceses que estaban en conocimiento del gran desarrollo del sistema educativo en Prusia durante el siglo $\mathrm{XIX} \multimap \mathrm{cl}$ que sería imitado por muchos países europeos- advirtieron que el triunfo de aquéllos estaba directamente relacionado con su educación.

185 Georges Cuvier: (1769-1832) importante naturalista francés del sigio XIX creador de los estudios comparados de anatomía y paleontología. El resultado de sus investigaciones fue publicado en sus obras Récherches sur les ossements fossiles de quadrupèdes (1821) y Le Règne animal distribué d'après son organisation (1817) (E. B. 6: 931).

186 Alexander Humboldt: (1769-1859) viajero y naturalista alemán, el primer representante del período clásico de la geografía física y biogeografía. Se lo conoce por sus investigaciones sobre la corriente oceánica de la costa occidental de Sud América, la corriente de Humboldt. Entre sus obras, Kosmos, 5 vols. (1845-1862, el quinto volumen póstumo), Nova Genera et species plantarum, 7 vols. (1815$1825)$ escrita con Bonpland y C. S. Kunth (E. B. 11: 833). 
¡Desgraciada la nación en cuyos hogares solamente sigue la lección del odio a los que triunfan, el odio a muerte a los que batallan y llegan a la meta de su ambición!

¡Desgraciados aquellos pueblos cuyos hijos, educados en un ambiente doméstico en el que sólo se ve el gesto y se oye el grito de la ferocidad desenfrenada por los desequilibrios sociales, no tengan más tarde otros sentimientos en su alma que los que hayan dejado esas pasiones!

La lucha, toda vez que tenga un fin, un objeto, es la ley fundamental de la vida. ¿Para qué luchar sin objeto?

Mas ya que la gentileza de los Señores Convencionales ha subido, impulsada por la elocuencia deslumbrante de Toribio Albarda, al extremo de concedernos la plenitud de los derechos electorales, nosotras venimos a dar gracias por su gentileza, tanto mayor cuanto que ha satisfecho el amor propio de la mujer, sentimiento tan delicado como vehemente, manifestando que, si ella hubiese faltado, nos habríamos convertido en sufragistas incansables y tumultuosas, lo que ahora, no solamente no ha de ocurrir sino que manifestamos espontánea y colectivamente que renunciamos a la satisfacción de que tales concesiones figuren en nuestra Constitución en la que sólo desearíamos, sin exigirlo, ver consignado que los derechos electorales de la mujer no fueran acompañados de la imposición militar del voto obligatorio sino que quedaran abandonados a nuestra voluntad.

De esta manera se salvaguardan nuestros prestigios doméstico y social, se conjuran los peligros de la lucha política en el seno de las familias y se salva el principio de la superioridad de nuestro sexo en la educación de la niñez y de la juventud en un país en el cual no ha existido, no existe, ni existirá jamás el temor de una intromisión retrógrada, exótica y metafísica, que es la que en otros países ha dirigido la pluma de escritores mercenarios. Tenemos patria, honor y libertad sin más directores espirituales que los que surgen de nuestra conciencia.

Y con las consideraciones debidas a los Señores de la Convención Constitucional los saludamos con todo el aprecio que merecen.

Molenia, Octubre 15 de 1913.

(Siguen 100 volúmenes de firmas de 500 páginas cada uno.)

En la sesión celebrada por los Convencionales durante la cual se leyó la nota precedente, las exclamaciones fueron iniciadas por Moloso, el cual dijo:

— ¿Es claro! Así tenía que suceder.

Pero ni los Estados Unidos del Norte, ni Inglaterra, creyeron que tal medida fuese de aplicación en sus respectivos países, y se contentaron con decir:

—“They say so, but they don't mean it." 187

187 They say so, but they don't mean it: ellas lo dicen, pero no en serio. 
Lo que es un hecho innegable es que nadie leyó los 100 volúmenes, que se reservaron como deleite futuro para los grafománticos. Algún día publicará Monalia el resultado de tales investigaciones.

$$
\text { * * * }
$$

Cuando el Gobierno Central hubo tomado todas las medidas necesarias para la Defensa Nacional, término tan secreto como muchos otros, envió un telegrama a Olimpio Pitango llamándolo a Molenia.

Su llegada fue triunfal.

Las banderas y gallardetes de las naves surtas en el golfo, impelidos por el viento, parecían una bandada interminable de mariposas multicolores. Los cohetes, petardos y bombas estallaban a cada instante entre el confuso rumor primero y aclamación después de 200.000 personas ansiosas de agasajar al prócer de La Reforma.

Los miembros del Gobierno Central se adhirieron personalmente a la manifestación declarando que no tenían derecho consagrado para invertir ni un centésimo en fiestas de recepciones.

Cuando Olimpio desembarcó, fue tan estrepitoso el saludo que se rompieron miles de cristales en las puertas y ventanas de la ribera, y aún más adentro.

¿Y cómo olvidar que el ilustre viajero llegaba del "ostracismo" el 28 de Febrero de 1914?

Estaba conmovido. Es cierto que no sospechaba una recepción semejante; pero las personas que lo habían acompañado desde Buenos Aires afirmaban que se quedó taciturno desde el momento en que recibió el telegrama llamándolo a Monalia. Un mal de ausencia más vigoroso que la nostalgia había clavado las garras en su corazón magnánimo.

Una vez calmado el deseo de oír la voz de Olimpio y de expresarle mil sentimientos de adhesión, de afecto, se puso en marcha con los miembros del Gobierno Central dirigiéndose a la casa de dicho Gobierno. Allí penetró y se repitieron las ovaciones, hasta que, saliendo a su balcón pronunció un discurso fogoso como siempre y ensalzó al pueblo como al pueblo le gusta - porque al fin, una cosa es el patriotismo y otra el conocimiento de los resortes sensibles. Todos extrañaron que algunos nombres, en otro tiempo habituales, no se mencionaron y lo atribuyeron a cierta influencia nefasta ejercida en el ánimo del orador por los porteños, que de 
todo se acordaban, menos de Molenia y de Monalia, y por consiguiente de su ministro.

Al fin pudo Pitango entrar en vereda.

Claudio Moloso habló en nombre de la Patria.

-Tu campaña, Olimpio, ha sido ruda, y por lo tanto más bri-

llante tu triunfo. Ya no se trata de un gran grupo de ciudadanos reducidos por tu elocuencia avasalladora sino de la Nación entera. Has tenido el talento de asimilarte el alma del pueblo en que has nacido y de reconocer que las formas graves de los anglosajones son incompatibles con los sentimientos de los monalitas. ¿Por qué negarlo? Hemos llegado a dudar de la integridad de tus facultades, cuya claridad has sabido velar hasta el último momento. Eres un Prometeo aconsejado por el Océano. Hoy estamos convencidos de que tus geniales invenciones de Cachimbo Pérez y de Botijo, se han transformado en símbolos de una aspiración nacional cuya satisfacción lastima los hábitos de una rutina secular, pero infecunda e inaplicable en la actualidad de la política universal. Y aunque ridículos por su nombre y ridículos por su tipo, los has hecho respetables porque has encarnado en ellos el sentimiento profundo de la Patria y, al darles un carácter, has tenido la habilidad de hacerlos casi contemporáneos de esas soberbias creaciones de Corneille, 188 entidades de una pieza, tipos definidos de rumbo fijo en los cuales la voluntad tiene un norte y el carácter una temperatura de rojo-blanco. Si hubieras empleado en tus arengas y en tus escritos la misma formalidad que caracterizó siempre tus manifestaciones intelectuales no se habría realizado esa ley invariable que rige la exteriorización popular de todas las grandes reformas y que participa de la locura. Para un auditorio de sordos absolutos los movimientos de un Paganini,189 de un Sarasate 190 o de un Dangremont serían exteriorizaciones de un loco de remate. Para realizar tu gran concepto has gesticulado como un violinista. Lee este corto discurso de Toribio Albarda pronunciado en la primera sesión reservada de la Convención. Si ha sido guardado en secreto para ti hasta ahora era porque la se-

188 Pierre Corneille: (1606-1684) dramaturgo francés creador de la tragedia clásica. Autor de numerosas obras muchas de ellas inspiradas en temas históricos, El Cid, Horacio, Cinna, Polyeucto, Rodoguna, etcétera.

189 Niccolo Paganini: (1782-1840) famoso virtuoso del violín y compositor italiano, cuya técnica fue brillantemente expuesta en sus 24 Caprici para violín.

190 Pablo Sarasate: (1844-1908) violinista y compositor español cuyo virtuosismo se inspiró en Paganini. 
guridad de la Patria exigía que continuara Krespel gesticulando en su violín de Cremona. ${ }^{191}$

Cuando Olimpio hubo terminado la lectura no pudo contener sus emociones, y lo que quizá hubiera expresado por una explosión de lágrimas un temperamento menos firme, estalló en un grito estentóreo:

—iViva Monalia regenerada y actual!

— iViva Pitango, el genio de la Defensa Nacional de Monalia! -contestaron los miembros del Gobierno Central y los demás concurrentes.

Restablecida la tranquilidad, porque aquellas voces sólo hiperbólicamente podían considerarse como truenos, habló Pitango:

-No sé, amigos míos, si las futuras Cámaras consagrarán una o más fiestas nacionales; pero la fecha de hoy, segundo aniversario de nuestra primera exteriorización política de carácter moderno, será, mientras viva, mi 18 de Julio, mi 25 de Mayo. Mi actuación, desde que inicié la Reforma, es la consecuencia de una larga premeditación, sintetizada al fin en un dilema que se transformó inmediatamente en acción pública, contemporánea de la invasión de Colones caritativos que venían a descubrirnos con entrada paga y que, con raras excepciones, no tenían más objeto que escribir libros que contenían, junto con amables verdades, soberanas pamplinas. Aquel dilema se formulaba de este modo: O expongo en forma seria y grave los fundamentos de la reforma necesaria y entonces me consideran un loco de remate y me encarcelan o me condenan al ostracismo o a algo peor, me marcan con el estigma del traidor a la Patria y en este caso mi obra es infecunda, o bien expongo esos fundamentos en una forma fantástica y descabellada para una minoría seria y grave, que me considerará loco de remate y me dejará en paz, pero imponente y necesaria para una mayoría abrumadora, y en tal caso hay probabilidades de triunfo y entonces mi obra puede ser fecunda. No había que vacilar. Tupitambo fue el primero que, en una correspondencia escrita en Europa y publicada aquí poco antes del 15 de Enero del año pasado, expuso el cambio que sufría allí la opinión respecto de mis actos, y no hay duda de

191 Krespel: personaje central del cuento de Hoffmann "Councillor Krespel”. Violinista, cuyo errático comportamiento es interpretado como locura. Representa al artista que encuentra la realidad oprimente y rígida (Selected Writings of E. T. A. Hoffmann, L. Kent, E. Knight, eds. [Chicago \& London, The University of Chicago Press, 1969]). 
que, a pesar del humorismo variado de un modo en extremo pintoresco, dio en el clavo, y guardé silencio, como hacen los locos cuando les descubren la locura. Presentada la situación en una forma perfectamente clara, sin necesidad de tamizar la hojarasca anecdótica de esa correspondencia, Toribio Albarda se constituye en apologista y defensor mío en términos tan bien definidos que me llamó a silencio, y cuando, pasados algunos días, y como quien dijera para mantener viva y ardiente la llama del patriotismo, le invento el hallazgo del retrato de Cachimbo Pérez, me mata el punto con una sagacidad y una travesura incomparables equilibrando mi descubrimiento con el de los antecedentes relacionados con Botijo. Por otra parte, el plebiscito del 10 de Junio resolvió la cuestión, y como siempre he confiado en la prudencia de ustedes, he vivido tranquilamente en Buenos Aires estudiando esa gran Capital del Sur, descubriéndola, hasta que vengan los Argentinos a descubrirnos a nosotros. Tenía intenciones de recorrer toda la República en el momento en que me han llamado. Por otra parte, no ocurre con Monalia como ha ocurrido con las demás Repúblicas Hispanoamericanas. En pleno siglo XX y henchida de civilización, ella no surge de la barbarie colonial, de la ignorancia, del fanatismo, del atraso en que aquellas dormían. Sus reformas políticas internas no consistirán sino en la consagración escrita de sus costumbres seculares, y su buen sentido patriótico conservará a su frente a los mismos hombres que la han dirigido hasta ahora. Pero las reformas vinculadas con la política internacional, esas son las importantes. Ya no es posible ocultar las ingentes riquezas de nuestras montañas, salvadas de la invasión de piratas por una simple cuestión de idioma. Las naciones que usan otros, en su gran mayoría, piensan que en castellano no se publica nada de importancia, y este error ha sido nuestra salvaguardia. Los elogios prodigados a la obra de nuestro genial muchacho Ciprio Potante son de una banalidad infantil: no la han leído; la han juzgado por los mapas geológicos, por la perfección tipográfica, por el método admirable en la distribución de materias; pero no conocen el texto. Si lo conocieran no habrían pasado inadvertidas sus profundas observaciones de comparación de sincronismos con el Sur de África, como que Monalia no es más que una parte de ese antiguo continente Gondwana que abarcaba las dos regiones, y eso a pesar de haberle suprimido ustedes, una vez que lo convencieron de la necesidad de ocultarlo, no sólo cuanto se refería a las minas de oro sino también a la documentación y comentarios relativos a la amplitud 
enorme de otros yacimientos probables, - y como ustedes expresan con la fisonomía una curiosidad extrema por determinar cómo es que tales cosas han llegado a mi conocimiento, les diré que fui yo quien señaló a Ciprio la conveniencia nacional de presentar a ustedes su obra antes de entregarla a la imprenta, porque la leí primero. Moloso.

—iQué hombre eres, Olimpio; nada se te escapa! -interrumpió

-Ahora están ustedes convencidos de que Olimpio Pitango no estaba loco.

- Cuando has tenido el talento de hacernos creer que lo estabas, no lo menciones, porque eso nos recuerda que no hemos sido suficientemente sagaces. Por otra parte, nuestro llamado dará testimonio de la convicción actual. El Gobierno quiere ampliar tus credenciales, y la Patria te lo demanda. Pasado mañana te embarcarás con rumbo a Montevideo y una vez terminada la gestión que te lleva, volverás a Buenos Aires. Vas a celebrar, ad referendum, 192 un tratado de alianza ofensiva y defensiva con la República Oriental del Uruguay y con la Nación Argentina. Tenemos el mismo origen, las mismas necesidades, la misma sangre y el mismo idioma. Si te arguyen con el estado de transición política por el cual pasa Monalia les dirás que dentro de dos meses todas las reformas constitucionales estarán realizadas, y en funciones las diversas ramas de un Gobierno republicano-democrático, municipal-federal, con una base militar de quinientos mil hombres de pelea perfectamente disciplinados, usinas de elementos bélicos, astilleros, hierro y carbón en abundancia, y un intercambio temporal de jefes y oficiales a elección de las naciones contratantes. Así lo ha resuelto el Gobierno Central, así lo acepta la Convención Constituyente que servirá sin duda de base al futuro Parlamento, y así te lo exige la Patria. Prepárate, Olimpio, servidor de ella en grado heroico, prócer legítimo, que al pisar el suelo nativo te yergues sobre un pedestal.

- ¡Sí! —exclamó Olimpio lleno de entusiasmo- acepto la misión, y la acepto porque estoy convencido de que nuestros vecinos aliados, cuando quieren, saben entender los grandes problemas escondidos en pocas palabras. Existe un peligro enorme para la libertad de las naciones sudamericanas, y que se revela a los que saben observar y deducir con juicio, por actos a los cuales la generalidad superficial no atribuye importancia, y entre ellos ninguno

192 ad referendum: lat., bajo condición de informar. 
le mayor magnitud que los ferrocarriles estratégicos del sur del Brasil en la proximidad de Misiones. Ni los orientales, ni los argentinos, ni nosotros tememos al Brasil, porque los diplomáticos brasileños son demasiado hábiles para no comprender que nada ganarían en una guerra contra nosotros, porque su país es demasiado rico en toda su vasta extensión para no satisfacer hasta las mayores pesadillas de bienestar y de riqueza, sin contar lo que representaría la ruptura de unas relaciones internacionales cada vez más afectuosas y más profundas dentro de la solidaridad americana, si he de expresarme con toda la ingenuidad de mi patriotismo sin dobleces. Esos ferrocarriles son obra de una sugestión, que ellos no han sabido pesar, porque los verdaderos intereses del Brasil no se encuentran en esas vecindades. Esta alianza se extenderá más tarde por todo el Continente Americano y si con Sáenz Peña debemos exclamar "América para el mundo entero" 193 en el sentido de proporcionar la riqueza y el bienestar a todos los hombres de buena voluntad que pisan su suelo, llegaremos al delirio de todas las crueldades para defender nuestra independencia nacional mientras quede en nuestras venas una gota de sangre viva.

\section{XIV}

\section{EN PLENA ORGANIZACIÓN POLÍTICA. - EL ALMA DE LAS REPÚBLICAS SUDAMERICANAS}

En sus gestiones diplomáticas tuvo Pitango un éxito completo, declarando los gobiernos Argentino y Oriental que estarían dispuestos a firmar los tratados una vez que la Nación Monálica se hubiese constituido en forma de acuerdo con la Constitución y proyectada y aprobada por los convencionales.

Y no procedieron con ligereza respecto del Ministro Plenipotenciario en cuestión, porque la actitud anterior del mismo quedaba

193 América para el mundo entero: el lema "América para la humanidad" fue expresado por Roque Sáenz Peña (1851-1914), abogado, diplomático, presidente del país (1910-1913) y autor de la ley de sufragio obligatorio. Roque Sáenz Peña fue uno de los representantes argentinos en el Congreso Panamericano, Washington (1889-1890) que más ardientemente “opuso a la fórmula estadounidense de América para los americanos, la de América para la humanidad, que reflejaba a la vez la decisión de algunos países de mantener sus vínculos desiguales con metrópolis europeas y la de los sectores que dentro de otros se oponían al avance ya amenazante de la hegemonía norteamericana" (Tulio Halperin Donghi, Historia contemporánea de América Latina [Madrid, Alianza Editorial, 1983 ] 288). 
universalmente explicada, no sólo por el éxito político de su propaganda, sino porque dejaba demostrado que, en los países sudamericanos, el camino más corto y más seguro suele ser el de los medios más absurdos, más incongruentes, más disparatados para llegar al triunfo, y como lo había dicho Pitango en la Junta del Gobierno Central, se puede desconfiar de un hombre serio y grave; pero nadie desconfía de un loco.

Estas doctrinas no eran viables en las prácticas europeas según los autores moderados o pelucones. Si Pitango, por otra parte, hubiese continuado incansable con su propaganda respecto de los próceres de Monalia, en particular aquellos más fantásticos vinculados a la Patria por una acción militar activa y sangrienta, absurdo colosal, desde que jamás habían dado batallas los monalitas, se habría podido pensar que su locura era real y positiva. Como lo había declarado el jurisconsulto, no empleó las formas graves para iniciar su grande obra, porque temió que ésta fracasara, ni pensó siquiera en una revolución armada, porque habría sembrado para siempre la semilla de la discordia nacional. ¿En qué se habría fundado, por otra parte, una revolución armada? ¿En los actos tiránicos del Gobierno? Pero el Gobierno era absolutamente paternal, juicioso, progresista y democrático por su origen electivo en períodos regulares. ¿En que las prácticas políticas de tres siglos habían consagrado la reelección? Pero la reelección mana de la voluntad de un pueblo que ve, en un acto semejante, la estabilidad de las instituciones bien servidas. ¿En actos de coacción electoral o de cualquier otro género? ¡Jamás! Ningún monalita se habría atrevido ni en sueños a realizar un acto semejante. ¿Ambiciones de mando? ¡Pero si el gobierno de Monalia no mandaba! ¿Aspiraciones de pompa, de deslumbramientos, de contratos leoninos, ${ }^{194} \mathrm{de}$ playitas? 195 ¡Qué disparate! Los deslumbramientos y la pompa no existían, como que los miembros del Gobierno Central no tenían sueldo; y en cuanto a los contratos leoninos y playitas, ni tenían existencia posible, dado el régimen económico del país, ni se hu-

194 contratos leoninos: contratos en que todas las ventajas recaen sobre una de las partes.

${ }^{195}$ playa: f. Arg. Par. y Urug. Explanada, lugar espacioso y llano destinado para usos especiales en los poblados y establecimientos industriales que ocupan mucha superficie. Arg. En las estancias, el lugar destinado a la esquila. Arg. y Chile, playa infantil (Marcos A. Morínigo, Diccionario manual de americanismos [Bs. As., Muchnik, 1966] s.v.). El significado que le otorga Holmberg en el texto, actos ilícitos o injustos, no aparece en ninguno de los diccionarios o glosarios consultados. 
biese encontrado quien se atreviera a proponerlos o a aceptarlos. No. La visión de Pitango se vinculaba con la seguridad de la paria, y esa visión flotaba indecisa, casi amorfa, en el espíritu nacional. Él había sentido como un gran rumor lejano, como un susurro de alas, como voces monitorias que no eran agüerías sino ideas que ansiaban corporizarse - y eso fue una inspiración profética. Cuando estalló su locura exaltada y ficticia, habló de próceres, de batallas, de victorias, de los grandes demagogos de los tiempos pasados, y el pueblo se dio cuenta exacta de que todo eso le falta$b a, y$ de que todo eso era necesario.

Su preparación jurídica, sus vastos conocimientos, su honorabilidad reconocida, su elocuencia vibrante y fogosa, todo contribuyó a que la Nación reconociera en él una síntesis de todas aquellas aptitudes ausentes de la actualidad, y lo convirtió de golpe en su ídolo inspirador.

A pesar de todas las proclamas universales de todos los congresos de la paz, de todas las mieles verbales de la diplomacia exteriorizada como una morisqueta carnavalesca, de todas las efusiones de confraternidad internacional, todavía pasaban por los aires las nubes de humo de la pólvora quemada en los campos de Grecia, de las Antillas, del Transvaal y de Orange, del Egipto, de la Manchuria, de Port-Arthur y de la Rusia; tronaba el cañón en Marruecos, en Trípoli, en el Archipiélago griego, en los Balcanes; y sobre los campos de batalla rugía siempre la necesidad de expansión territorial, de la depleción de las naciones abarrotadas de gente, de mercaderías, y en particular de las aspiraciones más o menos solapadas de la alta Banca, porque arriba de todos los congresos, de todas las mieles, de todas las fraternidades y de todos los sentimientos, se levanta la ley natural del hombre, de la lucha por la vida, y del triunfo de los más aptos, cualesquiera que sean los instrumentos que esa lucha pueda poner en juego.

Era necesario que Monalia fuese apta igualmente como nación, ya que lo eran todos sus ciudadanos. Él no tenía confianza en la buena fe de los leones sino cuando los leones carecen de colmillos y de garras, que es cuando no sirven para nada; él no aprobaba la conducta de otras naciones que han tenido próceres y ya no los tienen, que los cantan y glorifican como cantaban a la sombra de los poetas griegos porque les hacía falta en sus campos asoleados, y por lo mismo que los tuvieron se duermen sobre los laureles del pasado y adoran sombras intangibles sin tener un concepto claro del presente. 
Olimpio Pitango estaba convencido de que todas las naciones hispanoamericanas eran víctimas de una impregnación venenosa del espíritu añejo de su origen, con leyes civiles y militares hediondas de Inquisición y de Siete Partidas, 196 tufo de horcas y de conventos, infulas de republicanos que hablaban de libertad y democracia mientras hacían punterías a blasones apócrifos o banales; con pescuezos elásticos que de igual modo se erguían con el poder como se desdoblan ante el mandón; señores feudales civilizados y bruñidos en los grandes centros, y asesinos inmundos de cepo y de látigo en los tugurios solariegos adquiridos por la usurpación a los débiles; corazones corrompidos por el ejercicio de una autoridad secular ejercida sobre almas primitivas a las que no habían dado en tanto tiempo otra luz que la de los candiles, conservándolas bajo la influencia de un terror perpetuo con el nombre de religión, la que imponian con la amenaza o el azote, como lo habían hecho los antepasados con la hoguera y el martirio, mientras sus arcas, repletas de oro, les permitían representar todos los papeles de una tragedia de payasos.

Exenta de tales cánceres, Monalia se encontraba en condiciones de consagrar sus costumbres seculares en sus leyes escritas y realizar la Magna Carta ${ }^{197}$ en Sud América sin imponerse a Rey alguno.

Su permanencia en el Continente, la lectura constante de los diarios de todos los colores, le habían permitido establecer comparaciones de fecunda aplicación, e inspirando a sus prosélitos superiores como Toribio Albarda, había conseguido que el proyecto de Constitución mantuviera incólumes los derechos del ciudadano, que sólo podía ser juzgado por tribunales civiles, aún en tiempo de guerra. Esta innovación fundamental no ofrecería dificultades en la práctica cuando llegasen a Monalia los jefes y oficiales Orientales y Argentinos, ni menos cuando los monalitas (por el proyecto de reciprocidad) pasaran temporalmente a los ejércitos Oriental o Argentino.

Sin embargo, él no concentraba su pensamiento en un solo objetivo porque antes de ser un político era un gran patriota. El ambiente en que su actividad se desenvolvía en estos momentos era en extremo favorable para estudiar las ventajas y los inconvenientes

196 Siete Partidas: colección de leyes de gran interés histórico mandada compilar por Alfonso X el Sabio (1221-1284), que ofrece luz sobre la sociedad de la segunda mitad del siglo XIII.

${ }^{197}$ Magna Carta (Carta Magna): base de las libertades inglesas; constitución concedida en 1215 por el monarca Juan Sin Tierra al clero y a la nobleza. 
de una democracia incondicional. En su país, en la próspera Monalia, nadie se quejaba de su suerte, ni las condiciones económicas del país reclamaban los beneficios de una inmigración sin límites. En las naciones continentales, el espíritu absolutista de los primitivos colonizadores, servidos por una iglesia que había contribuido siempre a mantener la ignorancia en las clases inferiores, continuaba reinando; pero hubo un momento, a principios del siglo XIX, en que pudo quebrarse de un golpe con las prácticas añejas de un feudalismo intransigente: fue el grito de Independencia y la realización de ésta.

Para exaltar el espíritu de los pueblos, para que las manos de los guerreros improvisados se crisparan al empuñar el sable, la lanza o el fusil, era necesario comparar el cuadro del servilismo bajo el dominio del español, con el que se ofrecía para el porvenir y cuyas pinceladas llenas de esperanzas, de luz y de vida eran evocadas por las promesas de libertad, igualdad, fraternidad, la patria, la independencia, las garantías individuales y colectivas, la victoria del pueblo y por lo tanto la democracia triunfante.

Cuando en los campos de Ayacucho quedó quebrado el último eslabón de la cadena ibera, 198 cuando no se oyó más el rugido del león hispano en todo el continente, los pueblos no tenían para la democracia otra preparación que la de haber aprendido a obedecer con las armas en la mano.

La pretoría goda continuó siendo ejercida por los próceres de la libertad.

Aunque Olimpio conocía a fondo la historia de los pueblos sudamericanos, se detuvo en la Argentina. Libre ésta del yugo español, no pudo dedicarse a la educación de las masas porque la anarquía surgente de la libertad y de las turbas indisciplinadas trajo al fin la Dictadura. A los gritos de odio y de venganza que entronaban como himnos los Tirteos ${ }^{199}$ galoneados de la Patria surgente, sucedieron los gritos de odio y de venganza de la anarquía entronizada en todo el país al que no se le había enseñado lo que era fraternidad; los amos, los jefes, tenían demasiado poder para que los pueblos aprendiesen lo que era igualdad, $y$, en cuanto a la libertad, no la concebían sino como licencia. La Patria, por lo demás, era un

198 Ayacucho: (1824) victoria final de la independencia sudamericana de España, bajo las órdenes del general Antonio José de Sucre y los granaderos de San Martín.

199 Tirteo: poeta griego del siglo VII a.C., sus versos impulsaron a los soldados espartanos a la lucha durante la segunda guerra de Mesenia. 
concepto vago que olía a terruño y la independencia había pasado a ser una época histórica, y nada más.

Con la Dictadura 200 quedaron abolidas las garantías individuales y colectivas; el triunfo del pueblo se consagró con la ostentación del trapo rojo, y entonces la democracia triunfante pudo entonar su victoria coreándola con las palabras de amor:

¡Mueran los salvajes, inmundos, asquerosos unitarios!

¡Viva la federación!

¡Libertad! ¡igualdad! ¡fraternidad!

Cayó el tirano.

Un inmenso suspiro de alivio que los vientos esparcían por todos los ámbitos del país hizo desaparecer los últimos hedores fatídicos de las marcas de sangre de degollados, y la República tuvo claros de tranquilidad a los que sólo llegaba de tarde en tarde la sombra de nubarrones más fatídicos aún, que surgían como vapor de sangre en las Provincias Andinas, en el Centro y en el Litoral y que no tenían más razón de ser que la necesidad imperiosa de consolidar las garantías individuales y colectivas recientemente conquistadas.

La Patria tuvo entonces una Constitución.

El sufragio libre, la representación proporcional, las armonías surgentes de las libertades provinciales dentro de las garantías constitucionales consagradas dentro del régimen federal, la libertad de cultos, la religión de estado que permite a los gobernantes levantar una iglesia donde todavía falta una escuela, la guerra exterior que absorbe la atención y los recursos nacionales, ...todo esto representa el camino que conduce a la conquista de la verdadera libertad; pero no la libertad misma.

-En este país - pensaba Olimpio Pitango- no existen realmente los partidos políticos. La Constitución Nacional que consagra hasta el derecho de su reforma, y que en medio siglo no se ha reformado sino en el sentido de aumentar sueldos, es realmente una obra maestra. ${ }^{201}$ Sin que esto importe un cataclismo, se viola con

200 A partir de este párrafo se refiere al gobierno de Juan Manuel Ortiz de Rosas (1793-1877), estanciero argentino, militar, caudillo y jefe del partido federal a la muerte de Dorrego. Gobernador de Buenos Aires (1829-1832, 1835-1852) fue derrotado en Caseros (1852) por Urquiza, quien puso fin a un régimen de vioiencia. 201 Se refiere a la Constitución de 1853. Las Constituciones de 1819 y 1824 , precedieron a la Constitución de 1853. En 1949 esta Constitución fue reformada durante la primera presidencia de Juan Domingo Perón (1946-1955). Durante la presidencia de Pedro Aramburu (1955-1958), la Constitución de 1949 fue cancelada en 1956, e instituida nuevamente la de 1853 . 
frecuencia; pero el único partido de fundamento que puede existir por ella es el constitucional. De aquí nacen los partidos personales, los que, siguiendo la tradición, se odian a muerte. Hasta ahora las elecciones han andado como han andado, porque la masa numérica ha sido venal, y con frecuencia ha triunfado el que tenía la sartén por el mango. Consagrado el voto secreto, desaparece la venalidad; las elecciones son tranquilas; la fiscalización del acto que se realiza por delegados de los diversos partidos excluye toda manipulación vituperable con las urnas; pero la anulación de una o más de éstas, como ha ocurrido ya en muchos casos, porque los sellos no estaban intactos, no sólo no prueba una vigilancia intachable sino que acusa paladinamente a los que han triunfado con urnas intactas, y lo natural sería repetir la elección allí donde la urna se ha anulado desde el momento que los electores, legitimados por su libreta de enrolamiento no pueden ser privados de un derecho que la Constitución reconoce y la nueva ley transforma en un deber.

La elección del 7 de abril de 1912 dio el triunfo a los radicales con la mayoría y a los socialistas con la minoría en la Capital.202 Consagrada como un hecho la pureza de una elección, el partido radical, dados los elementos principales que lo forman, es un partido constitucional. En este caso, su aspiración consiste en procurar siempre el triunfo para mantenerse custodio de aquella pureza, lo cual es perfectamente legal. Los socialistas no. Su grito de guerra es otro. Si en los primeros existe una aspiración secreta, ella sólo es conocida por los iniciados; pero en los segundos la aspiración, el anhelo, el ideal, son del dominio público. Su existencia, como partido, es perfectamente constitucional, y, mientras respeten las leyes nacionales, nadie podrá inmiscuirse en lo que anhelan, porque eso corresponde al fuero personal inviolable. Como consecuencia de su programa político, su triunfo en toda la línea representaría la reforma total de la constitución en su forma y en su esencia, quitándole todos los fundamentos tradicionales que la han inspirado.

En las elecciones del 30 de Marzo de 1913, los papeles se han cambiado en la Capital. 203 El triunfo numérico de los socialistas

202 Alude a las elecciones de diputados en la capital realizadas el 7 de abril de 1912 en las que triunfan los radicales; los socialistas entran con dos diputados (Ezequiel Gallo, Roberto Cortés Conde, Argentina la República Conservadora [Bs. As., Paidós, 1972, 238]).

203 En las elecciones de senadores de 1913, los socialistas reciben 48.000 votos frente a 30.000 de los radicales (Ezequiel Gallo, Roberto Cortés Conde, Argentina la República Conservadora, 228). 
no tiene precedente en la República. Han sacado un senador y dos diputados con la mayoría, y los radicales un diputado con la minoría. Éstos, por su parte, han publicado un manifiesto, no un programa.

¡Olimpio Pitango! ¡mucho ojo! ¡mucho ojo!

¿Pero qué es esto que desde hace un rato se empeña en estimularme la imaginación y me hace cosquillas en el cerebro? Bueno; ya que aspira a que le dé forma, se la daré, y así me será posible dispersarlo y se desvanecerá la obsesión.

Cierto día se presentó un individuo a un Rey mostrándole un burrito que llevaba.

- ¿Y qué tiene de particular ese burrito? - preguntó el Rey.

-Tiene que es muy inteligente y me comprometo a enseñarle a hablar, a leer, a escribir y a contar en diez años. ello?

_iHola! ¡eso es una cosa extraordinaria! ¿Y qué me pides por de Rey.

- Que durante ese tiempo me mantenga su Majestad a cuerpo

- ¿Y si no lo consigues?

- Su Majestad me hace cortar la cabeza.

- ¡Convenido!

Y desde aquel día el Rey cumplió su palabra como Rey que era. Los amigos del quídam le dijeron:

-Eres un mentecato; sabes muy bien que no podrás cumplir el compromiso.

-Los mentecatos son ustedes - repuso el otro- porque no saben que, en diez años, o el burrito, o el Rey o yo nos hemos muerto.

Todo esto pensaba el prócer de Monalia.

\section{XV}

UNA DAMA DESCONOCIDA

Mientras Olimpio Pitango estudiaba los numerosos problemas sociales, económicos, históricos y políticos que debían servirle de fundamentos accesorios en tiempos no lejanos, cuando hubiera de desenvolver su indiscutible actuación patriótica que por el momento sólo se señalaba por sus actos diplomáticos, la Convención $\mathrm{Na}$ cional terminaba sus funciones en Molenia y entregaba al Gobierno Central el texto de la Constitución de Monalia calcado hasta cierto 
anto en el de la de Estados Unidos del Norte y otros derivados milares.

En tales circunstancias, el Gobierno decretó su impresión para istribuirla a todos los habitantes del país. En uno de los artículos lel decreto se imponía su lectura en todas las escuelas y establecinientos nacionales o particulares a lo menos una vez por mes. En tro se autorizaba la reimpresión libre de todo cargo, excepto el de levar el Visto Bueno de una oficina pública y con la condición de repartirla gratis.

Dos semanas después se convocaba al pueblo a elecciones de Diputados y de Senadores y como ya se ha visto que las elecciones eran rápidas y limpias, las dos cámaras funcionaban a los tres días.

Como rama del mismo tronco, la Constitución de Monalia era muy semejante a la Argentina, pero presentaba algunas diferencias muy esenciales que surgían de las tradiciones respectivas, siendo las más importantes las que se relacionaban con la religión, el divorcio, el voto y la elección del Presidente.

Libertad absoluta de cultos, lo que excluía la necesidad del patronato y de la representación oficial de cualquier iglesia. Los convencionales reconocían que el Estado no puede ni debe intervenir en lo que corresponde al fuero personal más íntimo, y como la Constitución disponía la redacción de todos los Códigos, ninguna falta ni crimen vinculados de algún modo con la Religión en concepto de alguien podían ser tomados en cuenta en el Código Penal. No se creaba una prisión nacional. Bastaba con el Manicomio Tarpeyo. A los desgraciados que de él caían al mar se les atribuía un "descuido" - en otros países los designaban como "resistidos".

El Divorcio no se conocía en Monalia. Pero los convencionales lo admitían en tres grados: $1^{\circ}$. de Medicina Legal; 20. de Justicia Ordinaria y 3o. de Justicia Superior, que podía resolverse por expatriación o por reclusión en el Tarpeyo. En cuanto al voto, se consideró que la situación política del país exigía la persistencia de las prácticas consagradas; pero en un inciso del artículo que a él aludía, se anunciaba la posibilidad de que tarde o temprano se aceptaría calificado.

El texto de la Constitución monalita es uno de los folletos más fáciles de adquirir y en cuanto a los Códigos, cuya redacción se ha confiado a los mejores jurisconsultos del país, aún no están publicados.

Las minas de oro, de plata, de cobre, de plomo, de carbón y de hierro pertenecen a la Nación, así como las cantidades que ésta 
necesita de los otros usuales. Los otros metales y las piedras preciosas no, excepto los diamantes necesarios para obras públicas de perforación.

La pena de muerte está abolida. (Pero los extranjeros mal intencionados dicen que algunos grandes criminales suelen caerse por casualidad desde el Manicomio de Tarpeyo al mar: 5.500 metros).

El pueblo de Monalia había realizado, pues, el fin de su delirio, y se preparaba a dormir sobre un lecho de laureles.

Primero el plebiscito, después la elección de convencionales, la Convención, la Constitución Nacional, elección de Presidente, de diputados y de senadores, y al fin y al cabo todo, en el fondo, funcionaba como antes, con las mismas autoridades, con las mismas ideas, pero después de variar un tanto los nombres. La Convención primero, y el Parlamento después, determinaron que la Constitución fuera jurada el 20 de Abril, fecha que se adoptaba como de la Gran Fiesta Nacional que sería celebrada anualmente con toda la pompa que admitiera el buen sentido. Cada cuatro años, en el día bisiesto, tendrían lugar también los Juegos Olímpicos, tomando por modelo los de los griegos, pues no solamente se dedicarían a todas las manifestaciones del ejercicio corporal, sino también del mental. Los poetas, los artistas, los hombres de ciencia, los intelectuales, en una palabra, presentarían allí sus obras, y conviene advertir que los superiores resolvieron imitar a Herodoto 204 y a Plutarco, porque la Nación entera reconoció que solamente de tales obras podrían surgir los verdaderos próceres de Monalia que tanta falta hacían, no solamente para satisfacer justos anhelos del orgullo nacional, sino también un poco por amor al arte y también pour la galerie. 205

Esta cuestión de los próceres era muy delicada. La Gran Comisión de Jueces nombrada por el Parlamento y presidida por Olimpio Pitango, resolvió rechazar toda obra histórica que no estuviese documentada, y someter a un tribunal de médicos alienistas a todo historiador que se valiera de la leyenda y de la tradición con preferencia al sentido común para justificar sus afirmaciones, pues la libertad de prensa le permitía afirmar cuanto quisiera y gastar

204 Herodoto: (siglo V a.C.) historiador griego llamado el Padre de la Historia. El tema central de su monumental obra Historia es la guerra entre Grecia y Persia.

205 pour la galerie: expresión francesa que significa para los espectadores. Se aplica a aquellas cosas que se hacen para engañar o halagar al público (Lisandro Segovia, Diccionario de argentinismos, neologismos y barbarismos [Bs. As, Coni, 1911 l] s.v.). 
todo el papel y tinta que tuviese a su disposición, y mandar al Manicomio Tarpeyo a los que, para hacer resaltar la figura de sus personajes predilectos aunque de menor cuantía, difamaran a los próceres legítimos.

El Manicomio Tarpeyo era el sitio más higiénico de la Nación. Estaba situado en la cresta más alta de la Cordillera Austral, en el borde del abismo. Su creación se debía a algún espíritu práctico. Allá, al pie y al fondo del farallón, rugía sin descanso la mar turbulenta. Sus bramidos se oían desde la cumbre; pero nunca revelaba los secretos del abismo.

Por lo demás, los oficiales y jefes orientales y argentinos ya ocupan sus puestos en las reparticiones de los Ministerios Militares de Monalia; y su porte, su competencia, su ilustración y su cultura, son el encanto de la mejor sociedad de la Nación, y especialmente del pueblo que los aclama todas las veces que al frente de las compañías, de los batallones o de los regimientos de jóvenes monalitas, dirigen su parte de ejercicios doctrinales. Algo análogo ocurre en la escuadra. Por su parte ellos son insensibles a los agasajos que se les prodigan, y es justo recordar también que los jefes y oficiales monalitas que se encuentran en los ejercicios de las Repúblicas Oriental y Argentina, de acuerdo con lo estipulado por las tres naciones, no encuentran términos, cuando escriben a sus familias y amigos, para significar su contento por las mismas causas.

Es una desgracia que el espíritu de la guerra no se haya extinguido, ni se pueda extinguir jamás en la Humanidad, género de mamíferos provisto de colmillos; pero es un hecho innegable que ninguna manifestación de simpatía alcanza, a lo menos aparentemente, proporciones más considerables que la que surge de tales expresiones de solidaridad internacional militar. Y es claro: la guerra es una brutalidad en acción; pero el militar es un altruista y casi siempre una víctima.

Desde hacía dos meses se había anunciado un gran simulacro, pero nada más. El secreto más profundo envolvía su fecha.

En la madrugada del 15 de Octubre, la Capital Molenia y todas las ciudades principales de la costa despertaron amenazadas por escuadras poderosas. Las naves pintadas de negro y, al tope, el pabellón rojo de guerra, sin que hubiese mediado declaración alguna, electrizaron a los monalitas. De Norte a Sur, y de Este a Oeste, llenaban el aire los clarines y tambores llamando a asamblea. Tronaban los cañones de los fuertes; nubes de humo surgían de los barcos invasores, pero ... iprodigio de la disciplina y de una alta 
dirección estratégica! el sol, al asomar por el horizonte marino, alumbró a 500.000 hombres, no acuartelados previamente, en marcha con todas sus armas y bagajes.

Cuando a las 11 de la mañana todos los clarines tocaron atención y fajina, las banderas de las tres naciones se izaban en todas las naves de guerra, enemigos presuntos, que así comprobaban el poder, la eficacia, y la seriedad de su alianza dentro de una disciplina perfecta incubada por un patriotismo generoso.

Tupitambo, que ya estaba de regreso en Monalia, escribió a sus amigos de otros países refiriéndoles todo cuanto había ocurrido en ese día; pero ellos no quisieron creer.

Aunque Monalia procedió en sus planes de defensa nacional con todo sigilo, algo se exteriorizó. Bastaba conocer el mapa de la Isla para que, comenzando por la suspicacia, la ciencia completara el conocimiento, en general, de los fundamentos de aquella defensa.

Su Prólogo era éste: La Defensa Nacional justifica todos los medios empleados. Muchos años antes, una nación sudamericana lo había proclamado, aunque, felizmente, no se llevó a la práctica. Bajaron a tierra con permiso en uno de sus puertos los marineros de una escuadrilla mandados por cierto jefe de altísima graduación de una Gran Potencia europea. Promovieron todo tipo de escándalos y desórdenes y el jefe del puerto los hizo meter presos. En cuanto lo supo el marino, envió una nota seca al jefe del puerto exigiendo la devolución de sus marineros para juzgarlos según las leyes de su propio país. El americano, con toda cortesía, contestó que las leyes propias de su Nación juzgaban las faltas y crímenes en el mismo país. El marino insistió con mayor crudeza. El jefe del puerto contestó que había comunicado el caso a su gobierno pues él no podía resolverlo sino por las leyes nacionales y esperaba la contestación. Al leer esto el marino pasó a otra cosa: "Si en el término de 12 horas no me devuelve Ud. mis marineros, bombardearé la ciudad". El gobierno del país, en conocimiento de esta nota, envió la siguiente: "Dentro del término de 6 horas abandonará Ud. las aguas de este país; si no lo hace, a la primera bomba que estalle en el puerto haré pasar a degüello a todos sus compatriotas. Dios guarde a Ud. muchos años". Y se fue.

En cuanto a la defensa natural contaba con el farallón del Sur mucho más inexpugnable aun que el de Gibraltar por el lado de 
aña. Por el Norte, miríadas de arrecifes, a flor de agua en su yoría en bajamar y aguas poco profundas. Por el Oeste, mar rbulenta; $y$ por el Naciente, en gran parte, altos farallones y arrees. Militarmente, un rosario de fuertes y baterías poderosamente tillados, más el recurso de las minas y submarinos, de los que seían modelos propios ejecutados como ejercicios científicos de iventiva en sus escuelas mecánicas, y así diferentes pólvoras desubiertas en sus numerosos laboratorios químicos. Respecto del aire, sus tácticos pensaban que de un momento a otro las naves aéreas estaban llamadas a representar un papel inesperado y no se abían dormido.

Los recursos de vituallas eran inagotables. El país no podía producir más de lo necesario y sólo recibía del Exterior lo superfluo en especialidades, muchas de las cuales podrían fabricarse allá mismo.

El servicio sanitario era completo, y los medios de transporte, suficientes ya, se aumentarían sin embargo.

Moralmente, consideraban recursos de primer orden el profundo sentimiento de la patria y de la unidad nacional.

Es de advertir que Monalia tenía tácticas de verdad y que su Estado Mayor había previsto ya todos los casos probables y posibles. Por el mar, y ésta es la verdad, confiaban sobre todo en los submarinos.

En tales condiciones, Monalia se dedicó a todas sus prácticas habituales de estudio y de actividad, en la confianza de que había hecho en favor de la paz cuanto era humanamente posible.

$* * *$

Por ese entonces bajó de las montañas una señora de porte majestuoso, ya de cierta edad, blanca de canas, y que vestía un traje de tela humilde. Nadie la conocía, o nadie la reconocía en Molenia.

Solían verla sentada en el banco de alguna plaza, con frecuencia rodeada de chicuelos de ambos sexos. Cuando les dirigía la palabra, todas las caritas se volvían hacia ella, y le prestaban tal atención que los ojos parecían como remachados y las bocas se abrían cual si un encanto especial les aflojara los músculos que sostienen la mandíbula inferior. Debía decirles algo muy interesante, porque no se movían.

Varias veces tentaron algunos adultos acercarse a esas reuniones extrañas; pero la señora se llamaba a silencio y los chicos quedaban inmóviles. Al parecer, los había disciplinado. 
Esto se repitió durante algunos días; pero nadie podía averiguar de qué se trataba, porque los niños guardaban el secreto en forma tenaz. ¡Es claro! Eso no se averigua; se adivina. Y a nadie se le ocurrió adivinarlo.

El hecho es que llamó la atención del mismo Gobierno, y en cierta ocasión en que, al parecer, había terminado su discurso y repartía caramelos a los chicos, se acercó a ella un caballero, y le entregó una carta. Rompió el sobre y sacó una tarjeta de

\section{Claudio Moloso \\ Presidente de la Nación Monalita}

Rogaba encarecidamente a la Señora pasara por la casa de Gobierno, si no tenía ningún inconveniente.

- ¡Señor!, sírvase decir al Presidente que estaré allí dentro de media hora, y manifestarle que se ha anticipado a mis deseos, pues pensaba hacerle una visita.

El caballero saludó y se fue.

Cuando media hora después era introducida en el salón del Presidente, éste, que se encontraba con sus ministros, le ofreció un asiento, y después de una ligera ceremonia social incompleta, le dijo:

- Señora: ruego a Ud. me disculpe esta libertad; pero no dudo que lo hará complacida en atención al móvil que nos ha impulsado, pues mi tarjeta contiene una expresión colectiva. ¿Es Ud. monalita?

-Sí, Señor; de las montañas, y hace muchos años que no he bajado a Molenia.

-Entonces queda todo en casa. Ud. no ignora que la mayor preocupación de nuestro pueblo ha sido, durante tres siglos, la instrucción pública, y continúa siéndolo. Varias veces la hemos visto a Ud. rodeada de niños, y cuando en alguna ocasión, reunidos aquí, hemos hablado de Ud., todos a un tiempo, al recordar la expresión de esos chicos, sin excepción, hemos citado unas palabras de Victor Hugo: "Hay momentos en que el cuerpo está de pie, pero el alma está de rodillas".206 Ellos guardan, sin embargo, su secreto, y aunque nos encontramos muy lejos de pretender quebrantarlo, no he-

206 No es la primera vez que Holmberg incluye esta cita en sus obras, apareció antes en el cuento "El ruiseñor y el artista" (1876). El juego de elementos en oposición (cuerpo, de pie/alma, de rodillas) es propio del estilo de Víctor Hugo, pero no he podido identificar la fuente. 
mos querido dejar pasar un día sin ponernos en comunicación con $\mathrm{Jd}$., porque realiza un ideal pedagógico, porque Ud. siembra un ncanto en sus oyentes que nadie puede igualar, $y$ hemos consideado que era obra patriótica pedir a Ud. su secreto para difundircomo una ley racional, y digo racional, porque no todas las lees humanas lo son.

-Mi secreto, Señor, es muy sencillo, y mi asombro no tiene medida al considerar que a nadie se le haya ocurrido adivinarlo. Por otra parte, esta circunstancia, aparentemente tan simple, ratifica la tesis que voy a desarrollar con toda brevedad. ¿En qué ocasión única de la vida presentan los niños el aspecto que Uds. han observado?

- Seguramente cuando escuchan algo que les interesa en extremo.

- ¿Y qué es lo que puede interesarles tanto? ¿La descripción de un simulacro?, ¿la de un objeto natural?, ¿las ideas filosóficas de...?

- ¡Pero si esto es más claro que el día! ¡los cuentos!

Todos se echaron a reír.

- Sí Señor, los cuentos. Y lo que yo hago es contarles cuentos. Desde hace muchos años, abrigo la convicción de que la grandeza real de Monalia se debe a esa preocupación constante de desenvolver, desde la más tierna infancia, las aptitudes individuales de los niños, colocándolos en condiciones tales que no distraigan su educación con temas que no les interesan. Pero hay un tema que interesa a todos los niños, y que se ha descuidado siempre en Monalia: los cuentos. No es una novedad, para personas de la ilustración de Uds., que la facultad más necesaria para el hombre intelectual es la imaginación. Sin ella no podrían los matemáticos que son, entre los intelectuales, los que más habitan el mundo del ideal, desenvolverse en la evolución de sus problemas, ni tampoco los químicos, ni los físicos, ni los naturalistas de vuelo. El músico, el poeta, el escultor y el pintor no alcanzan a tender sus alas sin ella, y la misma Historia y la Filosofía encuentran, con su ayuda, lo que la documentación, las meditaciones y los mejores talleres no pueden darles.

- Verdades son todas esas que no podríamos rebatir.

-Por lo común se presta poco cuidado al elegir los cuentos que se refieren a los niños, y eso, cuando llega con rareza el caso, y, por regla general, más se procura asustarlos, horripilarlos, y causarles pesadillas y contratiempos cuando duermen. Mi primera preocupación técnica es que me entiendan; me alejo de la realidad posible lo menos que puedo, intercalo con prudencia lo maravilloso y procuro bordar todo en un ambiente de alegría serena, poniendo todo mi 
empeño en obligarlos a pensar sin que lo sientan. Así es cómo, en mi opinión, se desarrolla la imaginación en los niños, y esto se ha descuidado siempre en Monalia.

-Pero Señora: todo eso reclama un talento especial y factores de que no todos disponen. Nosotros hemos sido testigos de una parte de esos factores, y ahora observamos otro: el timbre de su voz, que no nos es desconocida; y los que ya podíamos juzgar de vista eran la majestad de su apostura, la dignidad de su actitud y la expresión del gesto.

- $\mathrm{Si}$ Ud. considera que todo eso contribuye a los fines indicados, no creo que sea tan difícil adquirirlo.

-Pero hay otro factor muy importante, que seguramente pone Ud. en juego, y sobre el cual no podríamos opinar sin oírle uno de sus cuentos.

$-¿$ Se refiere Ud. a la ingenuidad?

-Sí, Señora.

- La crea el ambiente; no tenga Ud. duda. De tal manera estoy convencida de ello, que puedo asegurar, sin temor de equivocarme, que se reirían a carcajadas si les dijera que Uds., los que se encuentran aquí reunidos, pudiesen formar ese ambiente de ingenuidad que necesita el que refiere cuentos a niños.

-Y sin embargo, Señora, desde el punto de vista en que nos hemos colocado, o, si Ud. lo prefiere, tomando en cuenta la base patriótica de que hemos partido, no nos haría daño escuchar uno de esos cuentos.

-Ahora sí que me toca reír a mí. Pero al fin, no lo creo impracticable. En estos días se celebra en el Teatro Nacional una velada musical y literaria. Denme Uds. un número.

-Dicho y hecho.

-Pero debo advertirle, Señor Presidente, que no podré dirigirme a la concurrencia desde el escenario, como lo hace un artista. Será indispensable que me coloquen Uds. en mi ambiente propio, esto es, quince o veinte chicos de ambos sexos, y haciendo como que prescindo del resto de la concurrencia, les contaré a ellos algún cuento en que haya también un poco de ingenuidad para los grandes. Después veremos lo que se puede hacer con relación a la ley que Ud. hizo alusión.

- Se llevará todo a cabo, Señora, como Ud. lo indica. ¿Me hace Ud. entretanto el honor de darme su gracia?

-Por ahora desearía conservar el incógnito, y me llamo simplemente María. Pero antes de alejarme, deseo manifestar a Ud. mi 
isto orgullo patriótico. En ninguna parte del mundo se ha presenado el caso de que una curiosidad, que ha afligido hasta a los misos hombres del Gobierno, no haya hecho seguir por un esbirro a a persona a quien se quería conocer.

Hizo un saludo inclinando el cuerpo y, lo mismo que María Antonieta de Francia, abarcó a todos con una sola mirada, dando cada uno, Presidente y Ministros, lo que a cada uno correspondía. Y se retiró.

\section{XVI \\ LA PRINCESA RAYO DE LUZ (CUENTO). - EL FINAL DE UN DISCURSO DE OLIMPIO PITANGO}

La fiesta estuvo brillante, como sucede siempre en un país donde cada uno sabe lo que hace y donde sólo juzgan y aplauden o vituperan los que saben. Cuando llegó su turno, la señora María, rodeada de chicos, y dirigiéndose a ellos, dijo:

Érase que se era, en tiempo de Ñanga-Pichanga, un Rey muy poderoso que tenía:

una Reina muy bondadosa y muy linda que escribía cuentos para los niños y cosía ropas que daba a los pobres y que tenía:

un Príncipe heredero, su hijo llamado Picaflor, muy valiente y muy lindo, que tenía:

una hermana muy poderosa, la Princesa Diamela, y muy bondadosa y muy linda, que ayudaba a su mamá a coser las ropas que daba a los pobres, y muy valiente, porque nunca tuvo miedo de los ratones ni de las cucarachas.

Todos los habitantes del reino estaban convencidos de que la Princesa Diamela era la joya de la familia, y los sabios decían que era la síntesis de la familia, poderosa como el Rey, bondadosa como la Reina, valiente como el Príncipe, y más linda que los tres, porque tenía diez y ocho años y el Rey cuarenta y cinco, y la reina cuarenta, y el príncipe veintidós, y aunque éste era realmente muy lindo, como sabía que era valiente, se arreglaba el bigote de un modo imperial, y siempre fruncía el ceño, porque sus amigos le habían dicho que no basta que un príncipe sea valiente sino que debe parecerlo.

La fama de la Princesa Diamela corrió por el mundo, y todos los príncipes y reyes y emperadores jóvenes enviaron Embajadores a la corte del Rey Brumbún, que así se llamaba, como que era tan poderoso, y entregaron innumerables presentes de cosas inútiles, porque así lo exigía el buen tono internacional, para toda la familia.

El Rey entonces mandó acuñar unas cruces o estrellas muy hermosas de oro de 14 kilates que regaló a los Embajadores, y éstos, como testimonio de 
gratitud besaron la mano del Rey, el cual no les permitió besarle nada a la Reina, y ellos declararon que habían preferido darle un beso en los labios a la Princesa, porque en esa época no era antihigiénico besar en los labios a las princesas lindas, sobre todo cuando se hacía como testimonio de aprecio.

Los Embajadores se habían presentado en la corte con todo el ceremonial, y todo el aparato, y toda la prosopopeya que exigía el protocolo; conversaron más de una vez con el Rey y con el Gran Canciller y con el Gran Chambelán sobre asuntos de fraternidad humana, y sobre las lluvias y el arco-iris; pero a nadie confesaron que su verdadera misión consistía en estudiar a la Princesa Diamela.

Al día siguiente de llegar enviaron comunicaciones a sus comitentes diciéndoles por cifra que la Princesa era realmente muy linda; y los Príncipes, y los Reyes y los Emperadores se fastidiaron porque ya lo sabían.

Al otro día avisaron que era muy buena, muy hacendosa y muy caritativa, y los comitentes dieron una patada en el suelo, sin manifestar - porque hubiera sido impolítico- que habrían deseado estuviese bajo su taco la nariz del respectivo Embajador, porque todo eso ya lo sabían.

Un día después remitieron innumerables pliegos declarando que ignoraban por qué motivo se afirmaba que era muy poderosa; y los Príncipes, y los Reyes y los Emperadores dieron otra patada, pero con el otro pie, para que no se les torciera el mismo taco y creyese la gente que eran chuecos, y manifestaron que al fin había algo que ellos no sabían.

El Rey Brumbún y la Reina Bombón (éste era el sobrenombre que el Rey le dio al día siguiente de regalarle la corona) y el Príncipe Picaflor se dieron cuenta de cuál era la misión de los Embajadores. Eran muy perspicaces. Desde el momento que todos los días enviaban o recibían pliegos, sospecharon que estaban en comunicación frecuente con sus monarcas, $y$ como no se ocupaban absolutamente de cuestiones internacionales sino de hacer la corte a la Princesa, reconocieron, con esa clarividencia, que cuando la tiene ei vulgo se llama lógica, que su misión estaba vinculada con la Señorita Diamela.

Como el Rey Brumbún era tan poderoso, tenia odio a los tapujos, y entonces inventó un gran banquete con motivos internacionales, lo que no era un tapujo, y a él asistieron la familia real, los embajadores y los grandes personajes del reino. En aquellos tiempos de Ñanga-Pichanga, que casi eran tiempos heroicos, los invitados comían y bebían hasta saciar el hambre y la sed, reservando un rinconcito en su despensa anatómica para el momento de los brindis.

Y ese momento llegó.

El Rey, como un homenaje a su propia dignidad, se puso de pie, y levantando la gran copa de oro, dijo:

"Bebemos y brindamos a la salud de los ilustres Príncipes, Reyes y Emperadores que nos han enviado sus mejores ministros para que estudien secreta y profundamente a nuestra muy noble y amada hija la Princesa Diamela", - y vació la gran copa de oro, que su copero volvió a llenar. 
"Bebemos y brindamos a la salud de los ilustres Embajadores manifestándoles que la Princesa Diamela tiene un Hada Madrina, la cual le ha prohibido, so pena de convertirla en mala, fea y tonta que se case contra los deseos de su corazón y que tenga más de cinco años que ella, y que no sea un Príncipe, Rey o Emperador" - y vació la gran copa de oro, que su copero volvió a llenar.

"Bebemos y brindamos al buen retorno de los ilustres Embajadores que no quieran perder su tiempo ni el de sus monarcas que conocen ya nuestras reales comunicaciones"; ... - y vació la gran copa de oro que su copero volvió a llenar.

El Rey Brumbún, que era muy elocuente, hubiese continuado hablando; pero la Reina le pisó el pie con toda oportunidad, como hacía en todos los banquetes, y él no ignoraba que ese signo doméstico y burgués se refería al colosal tamaño de su copa de oro que vaciaba después de cada brindis, y aunque era muy poderoso, su gran poder no le impedía que fuera poderosamente fastidioso cuando prodigaba sus brindis. Por amor a la elocuencia él dijo a la Reina en voz baja que continuaría hablando con la copa vacía. Pero el Gran Chambelán que sabía traducir por el movimiento de los labios del Rey lo que decía, se levantó para acercarse a él, en momentos en que la Reina dijo a S. M.:

-Eso podría creerse si tu copa no fuera opaca y no estuviese llena; toma una de cristal.

-Al Diablo con el cristal —dijo el Rey.

- Un Rey poderoso no debe hacer uso de apariencias - dijo la Reina.

-Eso sería contra el ceremonial, Señor - dijo el Gran Chambelán.

— iAl Diablo con el ceremonial! —dijo el Rey.

- Mira, Pedro, si no te estás con juicio, me voy a levantar — dijo la Reina.

-El ceremonial te lo prohíbe -observó el Rey.

- iAl diablo el ceremonial! — dijo la Reina, y haciendo una seña a uno de los coperos, éste se dirigió con rapidez al fondo de la sala y descorrió una cortina.

En el mismo instante sonó un laúd.

Todos miraron en esa dirección y vieron un joven paje que arrancaba de las cuerdas tiernos acordes.

Nadie lo conocía.

Vestía calzas de color ceniza y casaquilla de terciopelo carmín, calzón verde abuchado, con acuchillados de seda dorada, zapatillas de tafilete rojo, cinturón blanco y espadín recto con empuñadura de nácar recamada de piedras preciosas, un gorrito celeste y una pluma blanca de paloma sostenida por un broche de oro en cuyo centro fulguraba un gran rubí circundado de brillantes.

Cuando acabó de preludiar sus acordes, inició una melodía tan dulce, tan delicada que todos los corazones volaron hacia él; pero lo que aumentó el entusiasmo fue la ejecución. Sus blancos y finos dedos volaban como 
mariposas agitadas en un torbellino, y de todos esos movimientos surgía un canto claro, afectuoso, insinuante, algo que hacía pensar en la gloria, en la juventud, en el amor, en el cielo azul, en las estrellas de la noche y en las que no se ven, pero que están siempre más allá, mucho más allá. Languidecía por momentos y era tanta la angustia infiltrada en las almas de los oyentes que algunos deseaban morirse y, cuando la tristeza parecía realmente mortal, surgían combinaciones nuevas como rayos de luz, como una aurora de púrpura y oro, y brillaba la vida llena de alegría, de vigor y de grandeza, noble, sublime, seductora, y terminaba con un acorde valiente que parecía una nota de amor decidido, categórico, invencible y triunfante.

El Rey entonces aplaudió y miró su copa vacía y a la Reina. La copa quedó inmóvil y la Reina sonrió.

Todos aplaudieron después. Las damas se secaron algunas lágrimas, y las que no podían llorar estornudaban.

La Princesa, que llevaba un pimpollo de rosa en la cabellera, se lo sacó, y le pidió permiso a su mamá para...

-No, niña; te lo prohíbe la etiqueta.

— iAl Diablo el ceremonial! —dijo la Princesa.

Y colocando el pimpollo en un plato de oro se lo envió al trovador con un copero, y él, no teniendo un ojal desocupado donde ponerlo se sacó el gorrito y lo aseguró junto al broche de rubí rodeado de brillantes.

El Rey presentó su copa al copero, el cual le hizo notar que se la había llenado a escondidas, y poniéndose majestuosamente de pie, se acercó al trovador, el cual apenas se mojó los labios con el vino y devolvió al Rey la gran copa de oro.

-Perdón, Majestad; si bebo no podré cantar.

- Mejor - dijo el Rey para su capote. - Parece que el muñeco este no se turba cuando un Rey poderoso lo sirve.

La Reina volvió a pisarle el pie.

El Rey la miró.

-Eres un aprovechador — dijo la Reina. - Esa copa está llena y ahora no más, distraído, te la vas a beber.

Oyóse un nuevo preludio; todos guardaron silencio, y el trovador cantó.

Los Embajadores se miraron.

- Muy peligroso - dijo uno en voz baja.

- La Princesa no tiene visibles ahora más pimpollos que sus labios. -Dijo otro en voz tan baja, que las mejillas de la Princesa se pusieron encendidas, como para demostrar que también tenía rosas de fuego.

- ¡Si habrá un caso de Lola-Ruk! —observó otro en voz más baja.

Jamás se había oído en el vasto reino de Brumbún una voz semejante. ¡Qué registro!, iqué poder!, ¡qué entonación! Era de una potencia sugestiva tan grande que, en ciertos pasajes, cuando la iba apagando gradualmente concluía por apagarla del todo, y sin embargo, continuaban oyéndola lejos, muy lejos, de donde volvía poco a poco y se levantaba por gra- 
dos como si penetrara, primero en las nubes y después más arriba, mucho más, allá en el cielo azul donde parecía que los ruiseñores coreaban la deliciosa melodía.

Cuando terminó, aquello fue delirio. El Rey se levantó, le dio un abrazo y ocupó su asiento; la Reina, no sabiendo qué ofrecerle, le dio un beso en la frente; y el Rey, por lo mismo, se bebió íntegro el contenido de la gran copa de oro, y la Reina ocupó su asiento; la Princesa se acercó a él, y él se ruborizó, se le hizo agua la boca y la Princesa le dijo que no tenía más pimpollos que ofrecerle.

- ¿Es posible? - preguntó asombrado el trovador, y la miró de un modo tan raro que la Princesa no pudo dormir desde entonces, y los médicos ignoraban lo que tenía.

Los Embajadores, personas muy cultas, muy distinguidas, se retiraron poco a poco. Cuando llegaron a su país, algunos fueron decapitados porque de todos modos, en concepto de sus monarcas, sus cabezas no servían para nada.

Entretanto, la Princesa languidecía cada vez más. Como los médicos no sabían por qué motivo, el Rey llamó a todos los sabios del Reino, y entonces celebraron grandes juntas. La pesaron, y tenía 150 libras, y como en esa época no había termómetros, ni rayos de Roentgen, 207 ni microscopios, ni química, ni nada, acudieron a las estrellas; pero como eran sabios, las estrellas estaban mudas para ellos.

Entonces la Reina llamó al Hada Madrina y el Hada dijo que lo único que tenía la Princesa era que estaba llena de música. Buscaron al trovador, pero éste no quiso ir a la corte, porque la Princesa tenía un nombre muy vulgar, el mismo nombre de una perrita lanuda de su tía Petrona, y cuando se quedó solo se le apareció el Hada y le dijo que no fuera tonto, que el nombre verdadero de la Princesa era Rayo de Luz, por lo mismo que se llamaba Diamela. ${ }^{208} \mathrm{Al}$ oír esto, el trovador bailó de alegría.

El Rey, entretanto, había celebrado varias conferencias con la Reina y ésta lo convenció al fin de que la enfermedad de la Princesa era porque estaba enamorada del trovador.

El Rey entonces se indignó, manifestando que era ignominia que una Princesa tan juiciosa como Diamela, hubiese puesto patas arriba el reino de un Rey tan poderoso; que los Embajadores se hubieran retirado descontentos; que todos los Reyes y Emperadores de sesenta años arriba les hubiesen hecho cortar la cabeza a los suyos como si de ellos dependiera lo que

207 Röntgen, Guillermo Conrado: (1845-1923), físico alemán que descubrió los rayos X. Fue Premio Nobel en 1901.

${ }^{208}$ Holmberg demuestra aquí sus conocimientos etimológicos: los dos nombres de la princesa, Diamela y "Rayo de Luz", se acercan semánticamente debido a la etimología de la palabra Diamela: la estrella, el jazmín del día (Diamela: Día, del lat. vg. día, y gemela, (especie de jazmín). (Joan Corominas, Diccionario crítico etimológico castellano e hispánico s.v.). 
buscaban; que hubiesen quedado al descubierto los médicos y los sabios por falta de termómetros y microscopios y rayos de Roentgen y química, y que nadie hubiese podido entender lo que decían las estrellas, y que hasta el Hada Madrina fuese tan bellaca que declarase que la muchacha estaba llena de música, como si se tratara del aire, y que fuera necesario desinflarla con ritornellos y baladas y preludios, y acordes y arpegios y trémulos, y todo a causa de ese mequetrefe que perdía su tiempo rascando tripas torcidas de gato en un laúd de morondanga...

—Vamos, Pedro; cálmate — dijo la Reina- hoy estás muy vulgar en tu lenguaje. Acuérdate de otros tiempos cuando tú también supiste conquistarte una Reina joven y linda en los torneos de lanza y espada y en los del laúd y del canto, y eso que tu Reina no pesaba más que 130 libras.

- Sí, pero ahora pesas 200. Además yo era un Príncipe, azul hasta las espuelas, y ese rascatripas...

-Acuérdate de dónde ha bajado la corona de los reyes, y con ella ese poder que, de una sola plumada, puede crear cincuenta príncipes y cien duques y doscientos condes...

-Bueno, bueno. Ya veremos eso. Entretanto, que venga ese trovador. Le daremos un banquete.

-No me parece conveniente. Lo primero que hay que hacer es que se cure Diamela.

-Bueno, bueno; arregla tú ese asunto. Al fin y al cabo los Reyes, por más poderosos que seamos, no sabemos discutir con las mujeres ni hacerlas entrar en razón.

La Reina se ocupó seriamente del asunto. El trovador fue adscripto al servicio de la casa real y desde el primer día se notó que la Princesa mejoraba.

Como era tan correcto y tan cumplido caballero, solían dejarlo solo con ella, y entonces la música era más dulce, más tierna, más íntima. A veces los acompañaba el Príncipe Picaflor, el cual, si bien es cierto que se moría de envidia cuando el trovador ponía en juego sus habilidades, no dudaba de que a fuerza de aplicación y de ejercicio podría llegar a igualarlo; pero habiendo cantado una vez en presencia del Gran Chambelán, el cual experimentó un violento desbarajuste de sus tímpanos al oír aquella voz de rana resfriada, le dijo:

- No cuadran estas nimiedades con la dignidad de Vuestra Alteza, y eso sin tener en cuenta que el protocolo se lo prohíbe.

— ¡Malhaya con el protocolo! —exclamó al Príncipe-. Y no volvió a cantar.

El caso es que Diamela mejoraba de un modo sensible. Su hogar, por otra parte, no estaba desolado. Disposiciones muy sabias del Gran Chambelán se oponían a ello.

En cierta ocasión en que el Rey había salido del palacio para una cacería, el trovador y la Princesa estaban solos. Aquél sentía que la inspiración del momento era única y de tal manera tocó y cantó que la Princesa, en un rapto de entusiasmo, le dijo: 
- Tu laúd y tu voz me llegan de tal manera al corazón que desearía poseer todas las flores del mundo para arrojarlas a tus pies; $y$ he sido tan ingrata, que sólo te he regalado un pimpollo en la noche del banquete.

Sin decir una palabra el trovador ejecutó un preludio breve, y con una expresión arrobadora, única, celestial, cantó:

Rayo de luz, en la cuna, te dieron por dulce nombre $y$ has de ser luz para un hombre, gloria y amor y fortuna, $y$ aunque protesten los sabios que nada entienden de amores para mi no hay otras flores que el pimpollo de tus labios.

Y se quedó mirándola.

Y como estaba acostumbrada a hacer su voluntad, porque para eso tenía un Hada Madrina se puso de pie, y acercando la cara le dijo:

- Pues si no tienes más ambición que esa, realízala.

El trovador no se lo hizo repetir y con una vehemencia impropia del lugar, de la persona y de la dignidad de ambos, estampó en el pimpollo de la octava un beso que sonó como un pistoletazo.

A muy corta distancia se oyó un ruido como de tos, o como de una garganta que quería ponerse en orden.

El trovador tomó rápidamente el laúd, y golpeando el suelo con el taco y pellizcando las cuerdas de distintos modos violentos estaba a punto de darse por vencido cuando se presentó la Reina, y le dijo:

-Es inútil, trovador;

pues estando yo delante

no le hallarás consonante

a ese sonido traidor. - Diamela, S.M. el Rey, tu Augusto Padre, te llama.

- Señora Reina y Madre; tendré el honor de comunicar a S. M. el Rey, mi Augusto Padre, que me encuentro completamente restablecida. - Y salió.

$¿ Y$ el trovador?

De pie, muy respetuosamente en presencia de la Reina; pero sólo un poco desconcertado.

-El caso es grave, muy grave - dijo S. M.

-En efecto, Señora; es tan grave, que mi vida pende de una sola palabra de los augustos labios de V. M. - repuso con voz tranquila, pero decidida.

-No hace mucho, joven trovador, que mis augustos labios se posaron en tu frente y los tuyos en el borde de la copa de oro del Rey. Quien tales 
mercedes ha recibido está libre de la muerte ignominiosa, porque lo que acaba de ocurrir aquí es un crimen de lesa majestad, no lo dudes. Pero tú no eres el culpable.

— iNo señora! —exclamó hincando una rodilla en la espesa alfombra. - iYo estoy loco de amor por la Princesa!

- iToma! El caso estaba previsto. El Rey, muy poderoso, te anticipa este pergamino. El Hada Madrina no podrá oponerse. De una sola plumada te ha hecho Príncipe del Rayo de Luz.

Tomó el Príncipe del Rayo de Luz la mano de la Reina y sus labios se posaron en ella con la suavidad de una mariposa en una flor. Y poniéndose de pie, dijo:

-Agradezco, Señora, la gracia que el Rey me dispensa; pero juro por mi honor de caballero que si mi sangre no fuera tan azul como la de la Princesa, jamás, nunca jamás, habría tenido la osadía de herborizar en sus labios: Soy el Príncipe Rayo de Sol, heredero del Imperio de Sichinta.

-Eso cambia de especie. Dame el brazo, Príncipe Rayo de Sol de Sichinta y del Rayo de Luz de Calamina y Rey supremo y poderoso del genio y del talento que llevas en el corazón y en la cabeza. Antes de salir de sus respectivos países, los Embajadores ya habían perdido su tiempo. ¡Desgraciados! algunos han perdido la cabeza también. El Rey nos espera.

Bueno, niños. Así fue como el Príncipe Rayo de Sol conquistó a la Princesa Rayo de Luz. Las fiestas de las bodas fueron pomposas como nunca. Duraron quince días, asistieron muchos príncipes y embajadores, y el Rey mandó acunar muchas medallas conmemorativas de cobre, de plata y de oro de 14 kilates. Los esposos encontraron muchos consonantes, fueron muy felices y tuvieron muchos hijos.

Y... Buenas noches.

La narradora fue muy aplaudida y una comisión de caballeros le pidió, en nombre del Gobierno, que se dignase aceptar una taza de té en la casa Central.

La fiesta improvisada tuvo mucho éxito como realidad. Hubo algunos discursos, pero el último fue el de Olimpio Pitango, que terminô así:

Porque hay algo, Señora, Señores, que la Razôn más poderosa no puede jamás destruir. Se derrumban las monarquías porque las repúblicas son la encarnación del más alto progreso político; se extinguen los pueblos porque la lucha por la vida los desaloja; se debilitan y mueren las religiones porque la razón las excluye; pero el sentimiento humano es la flor inmarcesible de la civilización y del progreso, porque está servido por la imaginación y la fantasía que son las energías motrices de la ciencia y de los descubrimientos. Este cuento tan sencillo en su forma, que los niños escuchaban "con el alma de rodillas" y nosotros hemos escuchado también 
como los niños, encierra un espíritu que coronará nuestra obra constitucional y de reformas, porque no basta destruir: es necesario crear sobre las ruinas. Mozart, Bach, Bellini, ${ }^{209}$ Donizetti, 210 Wagner, 211 Beethoven, Perrault 212 y La Fontaine ${ }^{213}$ sombras augustas que habitáis en el reino de los iguales, vosotros también sois redentores de la humanidad civilizada.

Y al decir estas palabras, todos pudieron ver, no, no pudieron ver bien, porque todos los ojos estaban empapados.

$\mathrm{Y}$ algunos lloraban como lloran los próceres.

Olimpio, quizá más conmovido que los otros, se acercó a la señora y le besó la mano.

-Sí, tú eres el mejor comprobante de mis opiniores - dijo ella.

Irguiéndose luego el prócer, dijo con voz ya serena.

- iCaballeros! ¡esta señora es mi madre!

Y entonces fue que el Presidente de la República de Monalia promulgó este Decreto (que más tarde aprobaron las Cámaras):

Nómbrase al doctor Olimpio Pitango Ministro Plenipotenciario, Enviado Especial y Extraordinario y Embajador ante las Repúblicas Sud Americanas, para invitar a todas a sostener la Doctrina de Monalia: South America for the South Americans. ${ }^{214}$

209 Vincenzo Bellini: (1801-1835) compositor italiano de ópera; su Norma otorgó nueva vida a las figuras rígidas de la ópera clásica. Otras composiciones: $\mathrm{Il}$ Pirata, I Capuletti ed i Montecchi, La Sonnambula.

210 Gaetano Maria Donizetti: (1797-1848) compositor italiano de ópera. Entre sus producciones más importantes, Lucia di Lammermoor, La Favorita, Don Pasquale.

211 Richard Wagner: (1813-1883) teórico y compositor alemán cuyas concepciones de profundo contenido simbólico tuvieron gran influencia en el desarrollo de la ópera. Entre sus obras: Tannhäuser, Lohengrin, Tristán e Isolda, El anillo de los Nibelungos.

212 Charles Perrault: (1628-1703) escritor francés recordado por su colección de cuentos Histoires ou contes du temps passé (1697), muchos de ellos de fama universal: "Caperucita roja", "El gato con botas", "La Cenicienta", "La bella durmiente del bosque", "Pulgarcito", etcétera.

213 Jean De La Fontaine: (1621-1695) poeta francés cuyas Fábulas (16681693) se consideran una de las obras clásicas de la literatura francesa.

214 Esta expresión, "South America for the South Americans" que apareció en el periódico La Prensa (dic. 21, 1902), reflejaba la necesidad de solidaridad de todas las naciones sudamericanas ante el bloqueo naval a Venezuela, iniciado por Gran Bretaña, Alemania y más tarde Italia, como represalia por la deuda financiera de Venezuela a estos países. Esta invasión originó la llamada Doctrina Drago (véase p. 197 ). (Thomas F. McGann, Argentina, the United States, and the InterAmerican System 1880-1914 [Cambrigde, Massachusetts, 1957] 218-221). 
Y cuando este Ministro munido de un modo especial de todos los títulos que el Decreto le confería hubo realizado la gira por todas las Repúblicas Sud Americanas regresó a Monalia, conferenció (como en otros tiempos difíciles) con el Presidente y le declaró de palabra, antes de hacerlo por escrito, que:

Todas las Repúblicas Sud Americanas se unían en un solo pensamiento y adoptaban la técnica de Monalia no solamente para las elecciones libres sino también para la escuela militar desde la edad de 3 años. 


\section{VARIANTES}

\section{Criterio seguido en la presentación de las variantes}

En su mayor parte las variantes son modificaciones realizadas por Holmberg que iluminan el proceso genético y de elaboración de la obra. Estos cambios muchas veces son indicaciones para una lectura más apropiada; otras veces son amplificaciones o explicitaciones, escritas generalmente en las páginas en blanco enfrentadas al texto.

Holmberg, que persigue en su novela una pluralidad de discursos, muchas veces sustituye vocablos por otros que mejor reflejan el nivel lingüístico apropiado. Así se rastrean cambios de vocablos cultos por otros populares, cuando el texto rechaza un cultismo por artificial.

La transcripción de las variantes ha ayudado a una lectura correcta del texto definitivo. Para la transcripción de las mismas se da la página y la línea. Entre corchetes se indican las enmiendas hechas por Holmberg [enm.], las tachaduras [tach.], los agregados [agr.], la lectura dudosa [lec. dud.], y las erratas [err.]. Entre llaves $\{-\}$ se introducen los cambios dentro de las variantes. Para facilitar la localización de la variante, se da su punto de inserción con la palabra que la precede o la sigue.

\section{Estudio de las variantes principales}

Según informa la extensa nota de Holmberg, que se transcribe aquí en el Apéndice, la idea generatriz de la novela fue la anécdota que Holmberg escuchó en la Inspección General de Enseñanza Secundaria, sobre ese personaje en el que perduraron las "exteriorizaciones del lenguaje parlamentario mucho tiempo después de la 
cesación del mandato", dato importante para comprender muchas enmiendas realizadas por Holmberg a lo largo de la novela. Holmberg, como ya lo manifestó antes, consideraba que "la expresión pura" era "la espada de la inteligencia" (La noche clásica de Walpurgis, 47); y en las relecturas del manuscrito, fiel a este principio, él pulió muchas expresiones o las cambió por otras menos artificiosas, o que mejor reflejaban el registro representado.

Cuando después del artículo incendiario de Olimpio Pitango que conmovió a toda la población, se inició el proceso institucional, decidieron instituir ese día como el más grande de la nacionalidad, y todos gritaban aprobando:

hasta que no pudiendo gritar más, al sentir que les iba a faltar el resuello para el grito supremo, estallaron en voz económica pero profunda:

- ¡Al fin tenemos partidos políticos y comités! $(88)^{1}$

Resuello es el resultado de dos cambios anteriores. Originariamente la palabra era: la energía, luego fue el aire, y finalmente Holmberg escribió el resuello, que mejor describe la magnitud de los gritos de estos nuevos políticos. Idea que se complementa con el segundo cambio, estallaron, que por su efecto explosivo, define más la situación que el vocablo previo, vociferaron.

Otro ejemplo de rechazo del lenguaje artificial se advierte constantemente en el cuento "La Princesa Rayo de Luz", donde la prosopopeya y el ceremonial de la corte se destruyen, primero, con los nombres vulgares de la familia real: el rey Brumbún, la reina Bombón, la princesa Diamela, el príncipe Picaflor. Segundo, que estos miembros, a lo largo del cuento, manifiestan un desprecio por las actitudes, comportamiento $y$ lengua de la corte que los lleva más de una vez a exclamar: "Al diablo el ceremonial." Holmberg cambia cinco veces la palabra protocolo por ceremonial, que connota mas afectación:

-Eso sería contra el ceremonial, Señor —dijo el Gran Chambelán.

-Al Diablo con el ceremonial - dijo el Rey. (185)

-El ceremonial te lo prohibe -observó el Rey. (185)

-Al Diablo el ceremonial! —dijo la Reina. (185)

-Al Diablo el ceremonial —dijo la Princesa. (186)

${ }^{1}$ La paginación de los ejemplos de variantes en este estudio corresponde al texto; en la transcripción de las variantes que se hace a continuación, se dan los puntos de inserción de las mismas. 
Además de las variantes que buscan el concepto bien definido o apropiado, o los vocablos más expresivos o descriptivos, hay otros tipos que cambian completamente el contenido de primeras versiones, como así sucede con la segunda versión de los infiernos.

Holmberg, al redactar nuevamente esta parte, cambió la ordenación de los mismos: así el 2 do. "Infierno de los condenados", era el 3ro.; el 3ro. "Purgatorio" era el 4to.; y el 4to. "Limbo de los niños" era el 2 do. No sólo la numeración se altera sino también el tono, menos bombástico. En la primera versión los ataques contra la religión o la moral eran más fuertes. En la versión final Holmberg suprimió completamente las partes demasiado combativas; así, en el 1ro. "Limbo de los Justos o Seno de Abraham" tachó:

aquél que, yendo a Egipto con Sara, y habiéndola visto el Faraón de Egipto le regaló al marido, al día siguiente, muchas vacas y borricos y ovejas y carneros etc., etc. (137)

Alude al viaje de Abraham y Saray a Egipto, motivado por el hambre en su pueblo. Allí Abraham sugiere a su esposa que, como era mujer hermosa, se haga pasar por su hermana. Saray es llevada a la corte del Faraón, quien al otro día le regaló a Abraham "ovejas, vacas, asnos, siervos, siervas, asnas, y camellos" (Génesis, 12. 10-24).

Más adelante, volvió a cargar las tintas contra Abraham y lo tachó nuevamente:

en vez de llevarse al Empíreo las almas de todos esos badulaques que vendían a su mujer por unos pocos carneros menos cornudos que ellos que se cubrían el lomo, noble receptor de dignas palizas, con un cuero incontaminado por el agua y el jabón ... (138)

Del 2do., "Infierno de los condenados", aunque dejó entre los condenados a Sócrates, Platón, Aristóteles y Darwin, los fundadores de la filosofía y de la ciencia moderna, omitió a: Aristófanes, César, Bruto, Dante, Rabelais, Voltaire, Rousseau, Montesquieu, Diderot, Holbach, Lamarck, Ameghino, Buffon, Lavoisier, y Laplace, es decir todos hombres del pensamiento universal. Irónicamente Holmberg eximió dos nombres de esta lista: "Torquemada y los Borgias ya están curados y han ido al cielo". Es interesante puntualizar que entre los condenados figura el sabio paleontólogo argentino Florentino Ameghino (1854-1911), contemporáneo de Holmberg. (138) 
Las omisiones a veces aluden a aspectos de la historia argentina; Holmberg tachó todo un párrafo de la carta de Olimpio del 23 de julio, sobre sus impresiones de la Argentina, en el cual decía:

Los pueblos, como te decía, tienen muchas necesidades. ¡Si vieras cuántos próceres han inventado en este Continente! ya están consagrados -y eso per secula seculorum. (139)

La ironía reside en que el gobierno de Monalia alejó a Olimpio del país, porque proponía inventar próceres como tenían todas las naciones civilizadas, y la Argentina no sólo los había inventado sino que ya estaban consagrados.

Resultado de lecturas posteriores son los agregados que introducen hechos contemporáneos a la economía argentina. Así en la extensa carta de Olimpio sobre sus impresiones sobre la Argentina, fechada el 9 de setiembre de 1913, en donde hace un estudio de la sociedad y del porteño, Holmberg agregó todo el final referido a la carne y a su consumo, las plagas de insectos y las nefastas consecuencias de la libertad de comercio: la anécdota del italiano falsificador de vino (154156). Cuando Holmberg publicó esta parte de la carta con el título "El encarecimiento de la vida en Buenos Aires" (Fray Mocho, 25 de octubre de 1917), estos agregados que figuran en el manuscrito en la página enfrentada, fueron incorporados al discurso.

Otro extenso agregado es el final del capítulo XVI, donde reflexiona sobre la historia de las naciones sudamericanas y de la Argentina (170-174). Aquí analiza las razones por las cuales tanto las naciones sudamericanas como la Argentina, no están preparadas para vivir procesos democráticos. Ciertos hechos políticos contemporáneos en la Argentina corroboran su ineptitud para vivir en libertad: a pesar de la ley electoral de Sáenz Peña para evitar el fraude electoral (1912) éste se sigue cometiendo. Concluye con las reflexiones relativas a las elecciones de diputados en la capital, la del 7 de abril de 1912 con la mayoría radical y luego la del 30 de marzo de 1913, con el triunfo numérico socialista. Holmberg parece favorecer este partido, por su apertura política frente a la oscuridad que rodea a aquéllos, custodios de la constitución nacional aunque se viola con frecuencia.

Holmberg tacha un párrafo que informa sobre el origen del nombre Monalia, que conviene rescatar:

porque si Monalia es un nombre que puede haber querido significar una sola cosa lisa, refiriéndose quizá a la planicie elevada y unida en que 
se fundó Molenia, es seguro que a estas horas el mundo entero lo traduce "país de los monos" (el énfasis es mío, 112).

Luego Holmberg omite otra vez la palabra monos en el mismo párrafo y deja "estos locos de Monalia por espíritu de imitación". Esta afición de Holmberg de bucear en la etimología de los nombres, no es nueva, sino que aparece ya en sus primeras publicaciones.

\section{Corrección de erratas}

El estudio de las variantes permite comprender ciertas erratas que hubieran sido advertidas por el autor si hubiera pasado a limpio el borrador. Una, que afecta la cronología de la novela, es la de la fecha: 15 de enero de 1912 en vez de 1913 (121). En otra oportunidad, al estudiar las diferencias entre la constitución de Monalia y la de Argentina, Holmberg originariamente menciona dos, la religión y el divorcio, y las desarrolla. Más tarde agrega la del voto con su explicitación; finalmente añade "la elección del Presidente" y olvida desarrollarla (175).

Otras erratas subsanadas en la edición:

Cap. I: Mahavarata en vez de: Mahabharata;

Cap. II: Metagintion en vez de: Metagitnion;

Cap. IX: Vasishta en vez de: Vasishthas;

Cap. X: Mutzu-Hito en vez de: Mutsuhito;

Cap. XII: L'Académicien en vez de: L'Immortel, novela de Daudet;

Cap. XIII: se corrigieron los nombres siguientes: Bergman, Brongniart, O’Connell, Kenngott.

El plebiscito del 15 de Enero en vez de: el plebiscito del 1 de Junio.

Drago en vez de: Sáenz Peña. En esta última errata Holmberg atribuye a Drago la expresión: "América para el mundo entero", que como lo informa la nota explicativa en el texto, fue dicha por Roque Sáenz Peña en el Congreso Panamericano (Washington 1889-1890). Luis María Drago (1859-1921), ministro de relaciones exteriores durante la presidencia de Julio A. Roca (1902) fue el autor de la "Doctrina Drago" (1902), originada ante el bloqueo conjunto de Alemania, Gran Bretaña e Italia a Venezuela, por incumplimiento del pago de la deuda externa. En esta oportunidad Drago refuerza la soberanía de las Naciones Latinoamericanas, al 
especificar que la deuda pública no justifica la intervención armada de ningún país. La Doctrina Drago sería el suplemento económico de la doctrina Monroe (1823): "América para los americanos."

En el Apéndice, Holmberg expresa que Conan Doyle "publicó en The Strand Magazine una novela titulada Danger"; en realidad no fue una novela sino un artículo "Danger" que se publicó en el Fortnightly Review en febrero de 1913. tada]

* Pág. 73 [Toda esta primera página fue escrita en el reverso de la por-

2 On fait courir la voix [se ha cambiado esta expresión por la más apropiada: le bruit] qu'un des chiens

4 dans un trou du verandah [err.: de la véranda]

10 y [tach. ilegible] aún de

* Pág. 75

2 [El título del capítulo, con otra tinta, parece haber sido agregado después; originariamente el título era Monalia, tach. luego]

El pueblo. [tach.: Falsas] Opiniones

4 nuevos [tach.: descubridores] Colones

13 semejante [tach.: creencia, escrito encima: opinión], el que

14 de que [tach.: aquélla, agr.: ella] fue

15 de la Humanidad [agr.: aunque sólo sea en estilo figurado.]

18 fertilidad [tach.: no permiten, escrito encima: excluyen] la

19 limítala al [enm.: cerca del] Norte

20 y [tach.: en, escrito encima: hacia, deja: $e n]$ la parte

22 suavemente [agr.: como un talweg] hasta

* Pág. 76

3 cultivados [agr.: de las montañas $y$ ] del valle

4 variadísima [tach.: de ramilletes]. Las praderas

12 moderno, [tach.: de] unos

18 su vuelo un espacio [enm.: ese espacio] marítimo

22 camino, [agr.: $y$ asi ] excava tilados], y

de los [tach.: ingentes farallones, escrito encima: formidables acan-

24 sin [tach.: cesar, escrito encima: parar] el áspero

26 grietas del [tach.: promontorio, escrito encima: farallón]

29 proximidades del [tach.: farallón, escrito encima: acantilado] desde

38 habitantes [tach.: eran] fuesen

* Pág. 77

4 libertad era [tach.: orgánica, escrito encima: espontánea]

17 en [tach.: sendos, escrito encima: gruesos] volúmenes 
23 derecho de [agr.: mandar y de] combatir

30 para tener el lujo de [enm.: para ostentar el lujo de]

* Pág. 78

6 capital [agr.: Molenia] un historiador

18 teatro, [tach.: estaba, escrito encima: se encontraba] éste

* Pág. 79

4 se [tach.: dignó, escrito encima: se preocupó de] mencionar

11 El ciudadano que [tach.: lo presentó, escrito encima: hizo la presentación] inició

* Pág. 80

3 hace [agr.: más de] 40 siglos

* Pág. 81

$1 \mathrm{Al}$ [agr.: otro] día [tach.: siguiente] la prensa

11 diverso [enm.: diversa, tach.: carácter, escrito encima: indole] emigración [agr.: temporal] a Monalia

12 de la cultura [tach. ilegible, agr.: humana.]

19 la existencia de los Museos de Prehistoria Universal [enm.: Museos Universales de Prehistoria] viene a

30 Colón [tach.: musical, agr.: literario]

* Pág. 82

5 [título agregado: Un artículo incendiario. - Fervor político]

8 término [agr.: inmediato] o hacerse

14 invasores que [tach. ilegible, escrito encima: iban] a Monalia

16 pasando por [tach.: Apuleio], Petronio, Apuleio, Boccaccio [agr.: Cervantes], Voltaire

\section{* Pág. 83}

4 [agr.: Pero nunca fueron venales: jamás recibieron un centavo por el elogio, ni por la defensa, ni por el ataque.]

15 No conocemos los monalitas [enm.: Los monalitas no conocemos] los peligros

19 tiempos prehistóricos [agr.: o casi], y si

26 la paz [tach.: del siglo] de la edad de oro, el bienestar [tach.: $y$ ] la riqueza [agr.: $y$ la justicia]

28 ley [agr.: fundamental] de la vida [agr.: política]

31 los inventaremos [agr.: como han hecho otros] y como los pueblos 38 dedicarán [tach.: sendas] interminables

* Pág. 84

9 según [tach.: las afirmaciones de tres, agr.: los testimonios] de los que 
10 sino [tach.: afirmaciones, escrito encima y tach.: testimonios, versión final: documentos] de carácter

22 talento [tach.: a llenar] reconstitutivo

* Pág. 85

4 victorias [agr.: de] Tipitamba

9 artículo [agr.: leído con entusiasmo y en altas voces por todos los ámbitos de la Nación]

15-22 más tumultuoso [agr. desde porque cada vez lo leian hasta el final del párrafo, el rumor sinfónico de las arengas, pág. 107, con las cambios que se detallan aquí]:

17 elocuencia [agr.: $y$ verdad]

19 las muchedumbres [agr.: en ciertas ocasiones]

22 el rumor [tach.: verbal, escrito encima y tach.: fabuloso, escrito encima: sinfónico] de las arengas

27 el humo de las [tach.: fábricas, agr.: fraguas.]

29 levantado [agr.: estupefacta] y electrizada [tach.: como un solo hombre]

* Pág. 86

1 no [tach: fueron, escrito encima: se levantaron] todos los

6 iba [tach.: derrumbar, agr.: a sacrificar todo] su bienestar

10 se [tach.: inflama, escrito encima: enardece, tach.: suben todas] las llamas [agr.: le suben] hasta

11 y le [tach.: consumen, escrito encima y tach.: queman, escrito encima: consumen] todo el fósforo

14 útiles [tach.: es decir de la técnica del desenfreno, agr.: es decir les faltaba la técnica del desenfreno]

15 consecuencias oratorias [tach.: $y$ políticas.]

17 primeros [tach.: furores, escrito encima: fervores] del entusiasmo

19 jerarquías [agr.: oficiales] dentro de

22 propagar [agr.: -lo] con ellas [tach.: aquel incendio] los menos aptos se [tach.: fueron] eliminando [enm.: eliminaron] espontáneamente [enm.: espontánea] y sucesivamente

24 también, [tach.: de modo, escrito encima: hasta] que al fin

33 más [tach.: energía] vigor

40 y de los más [tach.: graves] pesados

* Pág. 87

11 y [tach.: levantemos escrito encima: mantengamos] cada vez más [tach.: alto] ardiente

12 [agr. desde: $y$ gritemos bastante, hasta el final del párrafo.]

21 el uno sosteniendo [enm.: sosteniendo el uno] que

23 patriotismo [agr.: en su forma secular] era inherente

27 entusiasmo [agr.: correlativo] sin 
29 embrionaria [agr.: o si se quiere latente en] que

* Pág. 88

1 [agr.: 18] de Julio, 27 de Agosto, [tach.: 39, escrito encima: 18] y 2

3 Metagintion [err.: Metagitnion]

4 fuerte [agr.: que lo que se grita en Lohengrin] hasta

6 faltar [tach.: la energía, escrito encima y tachado: el aire, escrito encima: el resuello] para el grito supremo, [tach.: vociferaron, escrito encima: estallaron, agr.: en voz económica pero profunda]

8 políticos [agr.: $y$ comités]

10 [aunque el título del capítulo: El mejor de sus escritores, fue tachado, se lo ha dejado pues responde a la intención totalizadora de la novela de poner títulos que contengan las ideas principales del capítulo]

11 [agr: Con tan fausto motivo] por todas

14 de marras [tach.: que ya, agr.: cuyo nombre] sonaba [agr.: ya] en los corrillos

161 de Marzo [agr.: de 1912 en] El Patriota

18 algo [agr.: nuevo] que [agr.: cae de su peso] que nunca

20 se ha [tach.: desarrollado] manifestado

25 las [tach.: mas] altas virtudes

* Pág. 89

2 sugestión [tach.: palpitan] de aquellos

$6 \mathrm{Al}$ escuchar anoche las improvisaciones de los oradores juveniles, en distintos banquetes, [enm.: Al escuchar anoche, en distintos banquetes, las improvisaciones de los oradores juveniles]

12 los dos [tach.: partidos, escrito encima: bandos] que

16 permita [tach.: consagrar] conmemorar

22 [tach.: Este articulo, escrito encima: Pero] fue

28 la fecha [tach.: conmemorando el 29 en los años bisiestos, y el 28 en los no bisiestos]

31 la insistencia [agr.: adversa] de los

32 tuvo [err.: tuvieron] su cisma también

* Pág. 90

11 forma, [tach.: pero] constituyendo

14 del 10 [agr.: siempre] más el 29 de Febrero

17 estableciendo [tach.: un convenio general por el cual, agr.: que] en tal fecha

20 Y téngase [tach.: presente, escrito encima: en cuenta] que

* Pág. 93

7 III [enm.: IV]

8 El Regulador. [agr. al título: Un documento. - Europa alborotada]

104 de Marzo [agr. un año ilegible, escrito encima: de 1912] 
12 letras [tach.: negras], las siguientes

19 nuestro partido, [tach.: en] el cual

21 opinión [tach.: en un] fundadas

22 pero el [tach.: tacto, agr.: tino] político

33 voto imperativo [agr.: $y$ secreto] de que

33-34 9 de Marzo [tach.: será en adelante, escrito encima: llegará a ser] uno [tach.: de nuestros] de los más gloriosos

35 comicio libre, [tach.: puro] no contaminado

* Pág. 94

8 documentos [tach.: agrarios] de nuestro

20 colega [tach.: del] de El Patriota [tach.: anuncia] proclama

22 porque [tach.: esta] el artículo

24 verba flexible, pintoresca, imaginativa, [enm.: verba flexible, imaginativa, pintoresca]

28 le hemos encontrado [tach.: siempre]

29 como [tach.: es] el [tach.: Partido] Patriota

31 februarios, [agr.: Insistentes] marciales, [agr.: e Insistentes] terciarios.

33 Lamentamos [agr.: también] que

* Pág. 95

13 no [tach.: vemos, escrito encima: veríamos] en ello

16 [agr. de, tach.: El día] 7 de Marzo

20 Cachimbo [agr.: de] Pérez

22 [agr.: de, tach.: El día] 8 de Marzo

24 intenciones [agr.: aprovechando de paso la terminología de nuestras frases culminantes] nos es grato

31 [tach.: El dia] 9 de Marzo

* Pág. 96

2 [tach.: El día] 10 de Marzo

6 [tach.: El día] 11 de Marzo

15 [tach.: El día] 12 de Marzo

18 revestidos [agr.: los delegados]

19 invitar a [tach.: todos] los ciudadanos

monalita [tach.: $a$, escrito encima: para]

2015 de [tach. palabra ilegible, escrito encima: Mayo]

25 espíritu [tach.: anticuado, escrito encima: vetusto]

28 empeño de [tach.: reformar, escrito encima: modificar] las costumbres

33 algo [agr.: $\sin$ ] fundamento

cámaras [tach.: que representen el, escrito encima: como] poder

37 En [tach.: posesión, escrito encima: presencia] de tales

38 de un [enm.: una, tach.: estado] ignorancia 
* Pág. 97

11 [tach.: fueron, escrito encima: han sido] siempre

14 congregaban [tach.: constantemente, escrito encima: siempre] un público

15 mayor empeño [tach.: $y$ habilidad] la ilustración general. [tach.: Cada] No se

19 realizado allí [agr.: en el mismo día] experimentos

28 pesadilla, [tach.: es una] verdadera

30 a convertirlas [tach.: en hechos que] por una sugestión

33 es un [tach. palabra ilegible] solemne

36 Marzo 14. [agr.: -Del Fígaro:] La

ha [tach: aparecido, escrito encima: estallado] en

*Pág. 98

6 cuando [tach.: de asuntos de] le zumbaban

9 escritores [tach.: extranjeros, escrito encima: europeos] que

12 propaganda [agr.: tan] perniciosa [tach.: en las] si llega

20 Rey, [agr.: a causa de la risa se] retiró

22 toma [agr.: a lo serio] los

27 masas, [tach.: algo] muchas

29 Pedro [tach.: se debe, escrito encima: quedaria bien] designar [enm.: designado]

30-32 [agr.: La Academia, por su parte, ha (tach.: resuelto, escrito encima: ha dictaminado, tach.: que las vocales, preposiciones y conjunciones, escrito encima: que las vocales sueltas\} no sean acentuadas, lo que representa una enorme economía de tinta]

* Pág. 99

2 que [tach.: saldrá mañana, escrito encima: primero salga] para himno

5 momentos [tach.: de componer, escrito encima: en orquestar] el

8 Hoy [agr.: se] ha [tach.: sido] embarcado

12 [agr.: Marsella-Marzo 14. On vend]

23 plasma la [tach.: noble] ilustre

* Pág. 100

6 lectores del [enm.: de] El Patriota

7 político [agr.: literario] de altísima

9 nos ha [agr.: ofrecido] ayer

19 [agr.: $y$ de E viva Garibaldi]

[tach.: La verdad, empero, es que no queda mal con la de muchas otras canciones populares.]

21 IV [err.: V]

22-23 [título del capítulo agregado]. Causas de superioridad. [tach.: 
Claudio Moloso]. Sud América [agr.: Continental]

30 patria [agr.: de origen]

* Pág. 101

3 [agr.: cuando en sus prácticas fueron tan altos como los de Aragón $y$ proclamando así los derechos del hombre $21 / 2$ siglos antes que estallara la Revolución Francesa de 1789]

8 exponían ante [escrito encima de una palabra ilegible] sus

10 resolvieron [tach.: ocultar el secreto] convertir en

secreto [tach.: el descubrimiento] el conocimiento

14 de que [tach.: el mayor] el solo hecho

19 procuraron [tach.: sobre todas las cosas] adelantarse

*Pág. 102

8 especies, [tach.: toda] Monalia

escuelas [tach.: que no podían] de todo

14 relativa [tach.: barbarie, agr.: dureza bárbara]

$21 \mathrm{La}$ [enm.: Las] única [enm.: únicas, agr.: entidades] metafísicas [agr.: superiores de carácter moral] que [tach.: conocian, escrito encima: enseñaban] los monalitas era [enm.: eran] la Verdad [agr.: y la Justicia]

24 No [tach.: la, agr.: les] definían [agr.: la Verdad]

diciendo que [tach.: la Verdad] es lo que

25 los hechos [agr.: las cosas] demostrándoles

34 los nombres [tach.: les educaban a la vez, escrito encima: se fortificaba de paso]

36 y [agr.: desarrollada] la aptitud

* Pág. 103

6 entendiesen [tach.: y la asimilaran como una condición, escrito encima: Más tarde podrian asimilarlo o rebatirlo. Respecto de la Justicia el procedimiento era análogo]

20 concepto $\tan [$ tach., escrito encima y tach.: acabado, claro, escrito encima: bien definido] de la aptitud

21 loco [agr.: mal patriota] y caduco

23-24 entendido [agr. y tach.: solamente] en la fabricación de vidrio solamente [agr.: o a otro reconocido apto en la confección de versos líricos].

25 [agr.: Y, tach.: Por que] es necesario

26 la edad de [tach.: tres, escrito encima: 3] años

26-27 ya [tach.: conocían, escrito encima: eran aptos para] todos

27 a los 15 [agr.: para] los de

31 apto para [tach.: hacer una estatua] pintar un cuadro

33 distinciones [agr.: especiales], no era 
40 catalanes [agr.: valencianos] andaluces

41 canarios [tach.: celtas, eslavos] ... tenían

* Pág. 104

2 mauritanos [tach.: de celtas, agr.: de eslavos]

3 rojos [agr.: $y$ según Basaldúa, habitantes de un continente sumergido, de una raza antiquísima (tach.: primitiva\} como los atlantes]

9 humo [agr.: al] que [tach.: tuvo] se reconoció

15 revolución [tach.: sin documentos], y una

19 ejercicio [agr.: natural] de las

21 centralización [agr.: absoluta] de poderes

22 pueblos [agr.: animados por el sentimiento profundo de la patria]

24 tenían la [agr.: clase de] dirección

27 imperiosamente [agr.: en una de ellas] la creación

* Pág. 105

6 enloquecer [agr.: de modo ostensible] a media

8 en sus [agr.: últimos] escritos [tach.: más fogosa] más ardiente

15 real [agr.: y comparable.]

20 no [tach.: discutieron] el caso [agr.: fue discutido]

21 propusiera [tach.: la fundación de un manicomio instituto que nunca habia hecho falta en Monalia para, escrito encima y tach.: el recuerdo] encerrar a Olimpio Pitango en él [agr.: Manicomio Tarpeyo]

22 no era [tach.: viable, agr.: justa]

23 encerrarían los numerosos [enm.: innumerables] oradores

31 Inglaterra, según telegrama de Río [enm.: Según telegrama de Río, Inglaterra,] ordena

* Pág. 106

8 que las [tach.: contiene, escrito encima: encierra, tach.: $y$ te alejarás de Monalia]. Aquí tienes el [tach.: pliego] que

10 energía [tach.: $y$ ] a tu talento [agr.: y a tu patriotismo] lo que

13 se fue [agr.: pero murmurando : -iQué lástima! iqué retardo! ¡cuánto tiempo perdido!]

20 pero en [tach.: casi todas] las [agr.: otras] naciones

28 se curará [agr.: porque ellos hablan como él, y \{tach.: mucho más\} hasta con mayor vehemencia, como que no mienten]

31 su rango [tach.: ha sido, escrito encima: fue] recibido [agr.: ayer]

32 Nación Monálica [agr.: Exmo. Señor Dr. Olimpio Pitango]

33 muy agasajado en [tach.: sus] diversos círculos y como [tach.: tiene] goza

39 el [agr.: Exmo. Señor] Ministro Plenipotenciario 
* Pág. 107

8 y en [tach.: $m i$ ] tu dulzura

9 me has dado cuerpo y alma, que me han [lec. dud.: faltado]

13 pedido. [tach.: Pitango lo revisó, escrito encima: Lo revisó el ilustre jurisconsultol tomando

14 escribió [tach.: Aquí se hermanan la gloria y belleza

$y$ el escritor debe ser muy prolijo

$y$ boy más que nunca

para \{tach.: arrancar\} expresar]

19 inspírame con tu [lec. dud.: acento]

22 que de la luz son la gloria

[tach.: $y$ antes que aquí, en mi memoria,

guarda mis tristes despojos

levantaré un monumento]

[escrito encima: y se queda en tu memoria

míos serán los despojos]

30 vale así; nuestro [enm.: así. Nuestro] Ministro

31 arengas y [tach.: escritos, escrito encima: artículos] políticos

33 Abril 19 ... [agr.: 1912]

34 nos ofrecen [agr.: el retrato o] la caricatura

*Página 108

1 retratos. [agr.: Conociéndole sus \{agr.: recentísimas\} afecciones, ha sido muy solicitado por los coleccionistas de estampillas postales]

9 guías [agr.: magnificos dientes], modales

12-13 abajo, [agr.: en el periodo siguiente alternan], las mejillas se le incendian alternativamente, [agr. lec. dud.: también], todo lo cual

14 diabólico [agr. lec. dudosa: $y$ fantástico]

18 exige; entonces [enm.: exige. Entonces]

24 embarramos. Nuestro [agr.: Aun fuera de agua, enm.: nuestro] Ministro

32 cumplirse [tach.: el año, escrito encima: medio año] de ausencia

37 Pitango [agr.: murmuró "Espia!"] se paseó

38 y [tach.: murmuraba, escrito encima: repetía entre dientes]: Botijo

*Pág. 109

1 pueblos [tach.: Sud Americanos], Señor Ministro

2 las glorias de los próceres [escrito encima y tachado: individuales, escrito encima: locales]

8 durante una semana [enm.: un mes]

$15 \mathrm{~V}$ [err.: $\mathrm{VI}]$

18 de la [enm.: las, tach.: Capital] cataratas

19 como [agr.: la] continuación

19-20 contrafuerte [agr.: de los mayores] situado [err.: situados] 
* Pág. 110

2 han hecho [tach.: señales, escrito encima: telegrama]

7 con afecto [agr.: la mano] tres ciudadanos

32 Aunque [tach.: los Ministros] nos han [tach.: manifestado, escrito encima: asegurado] que su presencia

40 Y no hay [tach.: más remedio] qué hacerle

* Pág. 111

1 artículo [agr.: descabellado pero] incendiario

23 gobierno, [agr.: cuyo jefe era Moloso, a quien invitaron a, tach.:

Todos invitaron a Moloso a] tomar la palabra.

25 meditado [tach. ilegible, agr.: con toda prudencia]

31 dictadura [tach.: $y$, agr.: o] la ley marcial

34 ¿Qué [tach.: nos queda que, escrito encima: podemos] hacer

37 primero [agr.: por un plebiscito] si la quieren

38 pertenece a sus [tach.: habitantes, escrito encima: ciudadanos]

40 excepciones, forman parte todos los ciudadanos [enm.: forma parte toda la población]. Olimpio Pitango, [tach.: excepcionalmente, escrito encima: inesperadamente] discreto

* Pág. 112

7 cuando [tach.: en la cuestión del Estado] al discutir

12-13 asuntos religiosos [tach.: porque si Monalia es un nombre que puede haber querido significar una sola cosa lisa, refiriéndose quizá a la planicie elevada y unida en que se fundó Molenia, es seguro que a estas horas el mundo entero lo traduce "país de los monos"] porque estos [tach.: monos] locos de Monalia por espíritu de imitación, van [agr.: a convertirse en creyentes $y$ a] dividir sus opiniones

17 ministros [agr.: extranjeros]; sus intenciones

17-18 buenas [tach.: seguramente] y retirarán

24 que [agr.: primero] había

26 Mayo [tach.: 3, escrito encima: 15] de 1912

30 representan [tach.: la expresión de] un derecho inalienable [tach.: de los derechos] de

33 por cuanto ella garante [err: garantiza] la mayor

* Pág. 113

3 el día [tach.: 9 de Marzo, escrito encima: $1^{\circ}$ de Junio del año corriente 1912] si quieren o no quieren que se [tach.: redacte una Constitución Nacional, agr.: reúna una Convención Nacional Constituyente.]

15 buques [agr.: europeos] de guerra

19 la mañana del [tach. lect. dud.: 14, escrito encima: 16] de Mayo

20 las cinco [agr .: europeas] de guerra 
29-30 inherentes a [tach.: un Gobierno constitucional, agr.: las reformas presuntas, habiendo exteriorizado aquella fiebre, por otra parte, la enorme importancia de las energías vitales de la Nación.]

33-34 batería de [tach.: la costa, escrito encima: las salvas]; el pueblo con [agr.: casi] todos los cohetes voladores [agr.: y bombas] que

37-9 (pág. 114) [agregado todo un párrafo que empieza: pero la verdadera, y termina con: militares inviolables.]

* Pág. 114

16 un modo que no [tach. lect. dud.: habría, agr.: daría] lugar

20 semejantes [agr.: $y$ desde aquella edad se sentía más orgulloso de tal deber que de tal derecho.]

25 formando el [tach.: 9 de Mayo, escrito encima: $1^{\circ}$ de Junio]

32 sin saber [tach.: bastante de Matemáticas, escrito encima: contar y escribir], el Gobierno

33 toque de [tach.: los] tambores [enm.: tambor]

35 deseen [tach.: una, escrito encima: la] convocatoria

35-36 Nacional [agr.: Constituyente] dos pasos

* Pág. 115

4 Antes del [tach.: 9 de Mayo, escrito encima: $1^{\circ}$ de Junio] los

19-20 tiempos [agr.: o algún distinguido paleógrafo ulterior] inventó

Hoc siqno vinces [err.: In hoc signo vinces]

24 que para [tach.: él tanto valiera Cristo como Júpiter, escrito encima: su cerebro de pensador no hubiera tanta distancia entre] Júpiter y Cristo

* Pág. 116

12 que [tach.: todo er] tó 'er

20 A medio día, a pocos minutos después, [enm.: Pocos minutos después de medio día] sonaban

28 VI [err.: VII]

* Pág. 117

1-5 cada una. [agr.: Por otra parte, hasta final de párrafo: grandes diferencias]

12 VI [err.: VIII]

13-15 [agr. el título: Una correspondencia curiosa de Tupitambo. Medio millón de ciudadanos vota en media hora. - Los constituyentes]

16 Poco antes de [enm.: del, tach.: esa fecha, escrito encima con otra tinta: 15 de Enero de 1913]

* Pág. 118

19 casos más [tach.: curiosos, escrito encima: extraordinarios] 
* Pág. 119

13 Mutatio optima quamquam paradisum gaudeatur [err.: Mutatio optima tanquam paradisus gaudeatur]

34 escritos. [tach.: Ese, escrito encima: Aquel] tono

* Pág. 120

2 y de [tach.: diversas, escrito encima: variadas]

30 o no han leído Homero y [agr.: se jactan de ello porque no existe un Alcibiades que los haga arrepentirse de una cachetada; ] no conocen a

* Pág. 121

4 El 15 de Enero de [agr.: de 1912, errata de Holmberg que afecta toda la cronología subsiguiente] como se había resuelto

11 estruendo [agr.: $y$ el olor] de la pólvora

19 religiosas, [agr.: directamente o por elevación,] con tales

* Pág. 122

11 esto se [tach.: ha hecho, agr.: hizo] por la

24-25 pie. [agr.: - A la una! a las dos a las tres!]

34 su deber, [agr.: y cuando tal forma de gobierno empiece a ser cara, los mandatarios irán a dar un paseo por el Manicomio Tarpeyo]

39 se [tach.: nombraron, escrito encima: instalaron] las comisiones

* Pág. 123

3 de las [tach.: comisiones, escrito encima: otras.]

9-11 [agr.: Al retirarse del recinto hasta administraciones papeleras!]

15 VIII [err.: IX]

16 Feminismo. [agr. al título: -Un telegrama y una carta de Olimpio Pitango, err. la carta de Olimpio se transcribe en el próximo capítulo]

22-23 Es verdad [enm.: Verdad es] que [tach.: $m i$, escrito encima: la] proposición [agr.: que voy a presentar] tiene acomodo

33 comparamos la [tach.: actitud, escrito encima: figuración] política 36 casos [tach.: modern] contemporáneos

37 constitucional [agr.: y parlamentario] porque

* Pág. 124

4 hasta [agr: alimentarse con las yerbas, tach. lec. dud.: comer el pasto] de los campos

* Pág. 125

1 Cronwell se la hizo cortar [enm.: se la cortó] a Carlos I

2 y es un hecho [agr.: comprobado]

5-6 se debió a las [enm.: los, agr.: Hados y a las] condiciones

6-7 incompleta, [tach.: aún] porque [tach.: éste, escrito encima: él] no 
había puesto [agr.: aún] en juego

7 táctica [tach.: primero] con Ariadna y [tach.: luego] más tarde con Fedra, [agr.: sino con Antíope]

9 de las [agr.: mutilaciones por] etimología más que de los [enm.: la, tach.: hechos] estética

14-15 no haya sido desempeñada alguna vez [enm.: más de una vez desempeñada] por

* Pág. 126

6 precedido por [tach.: su bermana] Belona [tach.: que es la, escrito encima: por la] Discordia

11 y cabellera [tach.: de reflejos] negra [agr.: como el Tártaro]

14-15 que ha [tach.: dado] hecho surgir de la tierra [tach.: $\mathrm{el}$, escrito encima: de un] golpe de [tach.: $s u$ ] tridente

18 del soldado [tach.: $y$ ] e infundiéndole

19 Palas Glauca [tach., ilegible] avanza

23 a tejer [tach.: prolijas] primorosas

* Pág. 127

1 llamarán de [tach.: punto de] Escocia

2 me impide [tach.: justificar, agr.: especificar.]

11 símbolo [agr.: de infinita tristeza] impregnado con

* Pág. 128

1 Nemrod, de [agr.: Aquiles], de Alejandro

4-5 de sus [tach.: anuncios, escrito encima: predicciones]

5-6 Zaragoza [agr.: las mujeres] derraman [lec. dud.: su] sangre patriótica [tach.: junto a, escrito encima: al lado de] sus hijos

8 entre [tach.: aquellas, escrito encima: las] turbas

* Pág. 129

4 Hace [tach.: unos, escrito encima: algo más de] veinte siglos

5-6 cantando [agr.: por última vez] al borde [agr.: de] un abismo

* Pág. 130

1-2 a que [tach.: ellos, agr.: los tontos con la prolijidad de un pedagogo chino] les

13-14 estruendosamente [agr.: al orador] significándole

20-21 Molenia el siguiente telegrama [enm.: el telegrama siguiente]

22 Julio 20 [agr. lect. dud.: de 1812, err.: de 1913]

25 Toribio. [tach.: Lo anuncié, escrito encima: Asi lo dije] en el

$28 \mathrm{Tu}$ [tach. ilegible] honda

29 gradualmente [tach.: la presentación, escrito encima: el despliegue] de los grandes [tach.: personajes] caracteres 
Pág. 131

1-2 primer [tach.: término, escrito encima: plano Otelo y] D'Artagnan

2-3 y [tach.: en primer término, escrito encima: a su frente] los hombres

4-5 Licurgo [tach.: fue un retrógrado que] quiso

7.8 de leyes [tach.: para] de acuerdo

9 constitucionalistas [tach.: modernos] contemporáneos

19-20 de política [tach.: práctica] positiva

* Pág. 132

22 ahora [tach.: está, escrito encima: se encuentra] en una [tach. lect. dud.: una grata] situación mucho más grave

24-25 [agr.: No; se creería que no has leído Esquilo. Acuérdate del consejo de Océano a Prometeo; "El secreto del hombre prudente está en parecer loco."]

* Pág. 133

2 profeta, [tach.: $y$, escrito encima: $e s]$ un vidente

6-7 Ese [enm.: Esa] gran [tach.: país, escrito encima: nación]

8 de costumbres, [agr.: de] carácter, [tach.: afinidades] de

9 menos [agr.: de] política

10 como [agr.: todas las] locuras

13 y eso [agr.: en los comienzos y] bajo la

14 hiperbólico, [tach.: habló de] brindó

20 monarquía [agr.: del Río de La Plata], lo que

23-1 (pág. 134) faltaría [tach.: más] sino

*Pág. 134

12 VIII [err.: $X$ ]

15 [tach.: Ya que ustedes son tan] "La China, mi caro

21 dominan [agr.: con su dinastía] en el

* Pág. 135

2 como [tach.: lo aman] los japoneses

5 errores [agr.: apenas] de 500 años

6-7 cultivo [escrito encima: de la morera, del] gusano de seda

10 genuina, [agr.: el resultado] de la

14 [tach.: El error de todos] Los filósofos [tach.: no consiste en cometer errores sino en] se imaginan

24 que [agr.: aún] no se

26 tierras [agr.: por ellos] conquistadas

* Pág. 136

12 por [agr.: más] ficticias

13 deseadas [tach.: en] frente a 
19 amor propio [agr.: lo que parece un empeine por jugar con gatos], se empeñan

21 Es una [tach.: maravilla] golosina

enviaré [tach.: uno de estos días, escrito encima: dentro de poco] para

* Pág. 137

7 Eneas [tach.: en compañía, escrito encima: ayudado por] la cadencia

12-13 mayor interés; pero el [tach.: cuarto] 4o. sí. [err.: Holmberg rehizo luego esta división de los infiernos y olvidó cambiar este número, que corresponde al 2o. de la definitiva]

15-3 (pág. 138) Abraham [tach.: aquel que, yendo a Egipto con Sara, y habiéndola visto el Faraón de Egipto le regaló al marido, al día siguiente, muchas vacas, y borricos y ovejas y carneros etc., etc... \{agr.: Toma la Biblia y vuelve a leer la vida de Abram y luego Abraham. Es uno de los ejemplos más vivos de lo que dije antes respecto de la evolución de la Humanidad y en particular del criterio con que debe juzgarse la ilustración, el carácter y la moral de los hombres según los tiempos o las épocas.\}] Pero lo

* Pág. 138

4 venerable [tach.: sanatorio] hospicio.

5 niebla [tach.: vaga, escrito encima: difusa] o humo

7 translúcidos [tach.: y me aseguran que así lo afirma Renan en un libro que estoy ansioso por leer. Siguen luego tres palabras ilegibles]. De modo

10-15 [agr.: Hay aqui una planta europea que llaman Cardo de Castilla (desconocida en Monalia). Cuando los frutos están maduros y abierto el penacho que los corona, el viento se los lleva y con mayor razón cuando el grano se desprende. Estos penachos caen a veces en los patios, se acumulan en los rincones, o los llevan las brisas de una parte a otra. Asi deberian andar las almas de los justos.]

[tach.: El $2^{\circ}$ infierno es muy \{tach.: interesante, escrito encima: curioso\}. Se llama el limbo de los niños. - ¿ Te imaginas el salón de ceremonias de Don Ramiro, lleno de polillas revoloteando inconscientes en un ámbito oscuro y con olor a todo lo que quieras? Pues así revolotean alli las almas de los nonatos y de todos aquellos párvulos que dejaron de funcionar vitalmente sin haber recibido el agua de bautismo. Pongo ahora en prensa tus meollos, no para que funcionen como endenantes, magüer tu protesta, y quiero que me digas si no hubiera sido mejor, en vez de llevarse al Empireo las almas de todos esos badulaques que vendian a su mujer por unos pocos carneros menos cornudos que ellos, que se cubrian el lomo, noble receptor de dignas palizas, con un cuero incontaminado por el agua y el jabón para soplarle al hermano el derecho de primogenitura, arrebatándola al padre ciego que en sus mocedades enriquecía su rebaño con 
brujerias de palitos moteados etc. etc., si no hubiera sido mejor, decia llevarse la mencionada colección de lepidópteros \{lect. dud.: tineinos\} para convertirlos durante el viaje en ornitópteros ptilogenos, asomáticos, apodos y anuros, como un contingente de querubines.]

[El 3o es el más interesante, $y$ si algún día llegamos a tener en Monalia todo eso que ya sabemos, será necesario poseer una Rotisserie como ésta. Se trata del Infierno de los condenados. iQué gloria! Alli se están friendo como buñuelos las almas de los que mueren en pecado mortal. A pesar de todo, ahi está Sócrates, Aristófanes, César, Bruto (los brutos van a otra parte, ya te diré a donde), Dante, Rabelais, Voltaire, Rousseau (Torquemada y los Borgias ya están curados y han ido al cielo), Montesquieu, Diderot, Holbach, Lamarck, Darwin, Ameghino, y naturalmente Buffon, Lavoisier, Laplace y centenares de otros pensadores. iQué hermosa verdad dogmática! ¡Qué club! iqué academia! ¡qué Ateneo! Alli arden, pues, las mencionadas almas, por toda una eternidad, como ratones empapados en kerosene perpetuo].

[El 4o es una creación soberbia \{tach. lect. dud.: muy interesante\}. Se llama El Purgatorio. Alli va una especie de burguesía intelectual. No son categorias como los alarifes del $3^{\circ}$ van alli los que se equivocan de mano, y se van por el empedrado en vez de tomar la vereda, los que consienten cuando sueñan, los que sufren a la vista de las estatuas griegas y padecen asmas efimeras \{agr.: frecuentes en la soledad de su arrepentimiento\}, los que mienten o trampean de mil pesos arriba, los que ...etc, etc. No vale la pena. Estas almas son convalecientes; pueden irse al cielo por 20 o 30 pesos en misas. - Me ha dicho el Rev. P. Losange que este infierno no existe realmente; pero que es una canongia para los Reverendos, porque alli sólo van los tontos, y con mayor razón los ricos ignorantes; pero que los hombres de verdadero valer se van de cabeza al Infierno de los condenados].

16 (pág. 138) -5 (pág. 139) [Versión definitiva de los infiernos escrita en el manuscrito en las páginas enfrentadas, las variantes siguientes corresponden a la pág. 138:]

16 No hay [agr.: alma de] persona de [agr.: verdadero] mérito

18 hierven [agr.: eternamente] y se

25 atroces. [agr.: Ahora] los criminales

27 que [tach.: va a pie] por una calle

* Pág. 139

5 voy a [tach.: estudiar] examinar bien

[tach.: Imaginate ahora que todo eso es dogma y el que no lo acepta, condenado.

¡Y pensar que por unos simples próceres más o menos inofensivos, casi me han linchado en Monalia! Vivo de asombros. Cuando entremos en vereda te voy a remitir dos correspondencias por semana\} \{esta página, la 103 del manuscrito, tiene aquí una gran perforación que corres- 
pondió a un párrafo tachado con anterioridad\} tach.: Bueno, pues, Toribio. Los pueblos, como te decía, tienen muchas necesidades. ¡Si vieras cuántos próceres han inventado en este Continente! ya están consagrados -y eso per sécula seculorum. Es como el dinero robado. Si te pillan, eres un miserable ladrón. Pero si te lo encuentran definitivamente cristalizado en tus balances, ya eres el respetado jefe de una familia rica $y$ honorable, $y$ si lo encuentras de buen humor al amigo Migoya, Rey de armas ocasional, te fabrica una ejecutoria de la que sales Conde por lo menos; si eres prole de Murcia te entronca en Galicia o en León y si eres de Extremadura o de Castilla, te convierte en Marqués valenciano o andaluz y si eres hidalgo de bragueta te entronca con la casa de Austria como quien dice mus.]

6 examines [tach.: todos] los archivos

8 cuando reinaba [tach.: aquí, escrito encima: alli]

11 rara habilidad para [tach.: deducir] elaborar

12 con lonas [agr.: remendadas] de techo de carretas y tablas [agr.: viejas] de mostradores

14 y si [agr.: uno por mil de] mis compatriotas olfatean [enm.: olfatea]

24 tres infiernos, [agr.: aunque] uno de ellos [agr.: es] muy

25 alegre, y uno [agr.: más] desalquilado

26 de pintar [lec. dud.: Pitriflini] envejeciéndolo

27 de tabaco, [tach.: comprar como de Praxíteles] o negar

28 porque [agr.: $n o$ ] le falta

* Pág. 140

6 IX [err.: $X I]$

7 Documentos [agr.: Régimen político de una nación modernizada. La Convención]

9 Agosto [agr. número ilegible, escrito encima: 9 de 1912 [err.: 1913\}] En el número del 4 de Marzo [tach.: (p. 30). Esta pág. corresponde a la del manuscrito donde se anunció el descubrimiento]

13 reconocida hoy [tach. ilegible] le permitiô

* Pág. 141

1-6 [agr.: Y luego agregaba: -El Patriota empero debe exigir que atruenen las trompetas de la Fama a causa del descubrimiento que acaban de hacer y sobre el cual no ha llamado la atención debido a esa modestia delicada que lo caracteriza. Veladas a veces las ruinas por arenas de playa marina deben presentar una vegetación de aspecto tropical] .Pero - [tach.: agregaba, escrito encima: continuaba] El Regulador

11 llena de abrojos y [tach.: no olvidemos] bastará

13 en [tach.: aquel, escrito encima: cierto] vaso

15 de las [tach.: afirmaciones] dudas

16 consignemos aquí [tach.: la interpreta] la reconstrucción

21 se arruinará en [tach. lec. dud.: fortuna, escrito encima: salud] 
24 Agosto [agregado: 11 de 1912, err.: 1913]. El Regulador

26 para pontificar [agr.: en todos los casos] cuando tiene

28 de insano [agr.: que es lo que sugiere la interpretación que ha publicado] por lo menos

38 arroja [agr.: como] al acaso

40 si no pudiera [enm.: pudiese, tach.: interpretarlo, escrito encima: traducirlo] cualquiera que

* Pág. 142

1-2 de sus "lectores". [agr.: ;Qué falta de ajuste! ¡Qué diferencia con el del original de Ñango-Pichango!]. Así son los corifeos

14 Toda la navegación [tach.: de mar y cielo] se debe a

19-20 de un Pichango [agr.: la existencia presunta de] toda una civilización

21 Agosto 12 de 1912 [err.: 1913]

22 llegó a Monalia [tach.: una] sumergida

25 del patriotismo y de [agr.: la] cultura

26-27 por causa de un [agr.: indigno] rompecabezas

* Pág. 143

3 Himalaya reperitum [enm. con tinta roja: repertum, tach.: convenit satis bene alterorum convenit] satis

6 en el Museo de [tach.: Monal] Molenia [tach.: a la], entre las

9-10 algún naturalista [agr.: Seguro que la letra del original, tan única, no puede ser de Teridion Pampelunio].

12-13 hace unos [tach.: veinte, agr.: 15] años, llevó a tal grado los elogios [agr.: prodigados a cierto Instituto], fabricó

16-17 donde han hecho camino, [tach.: donde] porque,

21-23 [agr.: ¡Qué sorpresa! Tenemos oportunidad, al corregir la prueba de comunicar a nuestros lectores la noticia de habernos llegado, en este momento, 3 interpretaciones nuevas: 1 en francés, otra en italiano y la $3 a$. en inglés].

24 El Patriota [dos palabras ilegibles, tach.: siguiente, escrito encima: de Agosto 13 de 1912, err.: 1913]

25 políticos [tach.: aplicando, agr.: haciendo] al latinajo

26 pero [tach.: este diario, poco des] se supo

27-28 no se ocupara más [tach.: del asunto] de las ruinas

33 y [tach. ilegible] dirigirse [agr.: luego] ambos, [tach.: poco después], a la oficina

* Pág. 144

8 fecunda de [agr.: inútiles] discordias ulteriores [tach.: En compan], tanto menos

18 Los unos [tach.: piensan] piensan

21-23 el aire. [agr.: Pero esto sirve de fundamento para deducir las 
monstruosidades a que podrán llegar los paleógrafos de Monalia cuando estudien o interpreten viejos legajos devorados por la polilla]

28-33 sitio elegido. [agr.: Esto demuestra la existencia de cráneos tan tenaces como su propio contenido y la necesidad de triturarlos para modificar su estructura porque la evidencia es inaccesible para ellos. Y demuestra también que muchas veces, para despejar tinieblas que parecen impenetrables, el camino más corto es el más simple: encender una vela]

* Pág. 145

3 moderna [tach.: es decir], una vez que

8 Monalia como [agr.: entidad] arcaica para convertirse [agr.: de un golpe] en Humanidad [agr.: moderna] ilustrada

17-18 fundirian las [tach.: chapas, escrito encima: barras] de acero con que se [tach.: forjan, escrito encima: forjan las espadas y se construyen] los acorazados

8-10 los submarinos [agr.: sin contar los otros instrumentos con que los pueblos defienden su existencia o luchan por la vida]; y los convencionales

11 transformación [agr.: fundamental] que creaban

13 no se promulgaría [tach.: hasta que] mientras

16-17 como sardinas [agr.: y se tragó luego su arpón].

19 sus manos [tach. ilegible, escrito encima: se apoyaba] el porvenir

22-23 atención [tach.: particular sobre mi persona, escrito encima: especial] porque la evidencia no [tach.: necesita, escrito encima: ha menester $d e]$ reclamos

24 instante [tach.: pero deseo] en este momento

* Pág. 146

1 anglosajones [tach. ilegible] estriba

2 cuando [agr.: $n o$ ] se trata

4 se llega a [tach.: una, escrito encima: las] solución [enm.: soluciones, agr.: deseadas].

7-9 fundamento. [agr.: no somos aptos para la continuidad de la tarea. Tenemos la versatilidad de los monos sin atención]. Monalia

$16 \mathrm{X}$ [err.: XII]

17-20 [todo el título de este capítulo parece haber sido agregado con los siguientes cambios:]

17 Pérez y de [tach.: Mam] la estatua

18 Botijo [agr.: próceres de Monalia] -Los secretos

21 Agosto 20 de 1912 [err.: 1913]

22 imaginar, [tach.: $m i$ ] querido [tach.: Toribio, escrito encima: amigo], a qué grado

33 se salvó en 1876 [enm.: 1875] del incendio

* Pág. 147

7-8 simetría del [tach.: cuadro, escrito encima: conjunto], y dime 
10 la unidad, [agr.: el equilibrio], la energía

28 derramando [agr.: su elocuencia] en lazos

32 una parte de los [agr.: antecedentes $y$ ] argumentos

37 plantea [tach.: una premisa] un silogismo

* Pág. 148

1 hechos históricos [tach.: que] justifican [enm.: justificativos de] la opinión

23 Aunque [tach.: en este pais, escrito encima: aqui] existen

33 Molenia, Septiembre 5 de 1912 [err.: 1913]

40 interpretación. [agr.: Al pronunciarlo], me han

* Pág. 149

4-8 unanimidad. [agr. en la pág. enfrentada: Por otra parte, hasta: no tiene probabilidades]. Creo

11 a tí [tach.: $t e$ ] lo debo

35 leer [tach.: Mam, escrito encima: Rup] ... Botixo

36 llamaba [tach.: Mamerto, escrito encima: Ruperto]

37 dato [agr.: lleno de] interesante [enm.: interés] el dibujante

* Pág. 150

1 con parte de [tach.: una, escrito encima: la] pierna

8 Monalia... magis [enm.: agis] (m)agno

18 Septiembre 9 de 1912 [err.: 1913 ]

28 aquí [agr.: algunos de ellos papyrognostas muy hábiles], están

* Pág. 151

4 precisamente [tach.: una, escrito encima: dos] de esas hojas

9 talento. Mamerto [escrito encima: Ruperto] (efectivamente, así se llamaba), Mamerto [escrito encima: Ruperto] Botijo

11 estentórea, y [escrito encima y tach.: muy] vibrante

17 más sonora, más [agr.: metálica, más] vibrante

18 he mandado hacer [agr.: al óleo] uno de perfil

20 elogios [tach.: con, escrito encima: en] tu recuerdo

31 -[tach.: $y$ ] ya sabes

34-35 una pirámide [agr.: de plomo] patriótica [enm.: patriótico] sobre 429 moscas y [tach.: un, agr. 1] mosquito

44 lleno de estupefacción [enm.: estupor] es el arte

45 entre los [enm.: esos] intelectuales

* Pág. 152

2 lo es de verdad, [tach.: $y$ ] consecuencia [agr.: y colocación].

3 nuestros [tach.: asuntos, escrito encima y tach.: tareas, temas] asuntos

3-4 causa [tach.: disgusto, escrito encima: malestar] cierta [tach.: trivialidad que] superficialidad que 
9-10 encuentras con [agr.: muchos] potentados

15 si bien [agr.: es cierto que] triunfan

16 superiores [agr.: por su naturaleza.]

18 casos, [tach.: no raros] relativamente

21-22 no se sabe [agr.: de un modo] positivamente [enm.: positivo] si existe [agr.: actualmente] o no crisis económica [tach.: en estos momentos, $y$ dirigen], así es que

23 de algo [tach.: evidente los] indiscutible, los

31 suprimido el muy [tach.: o se ha olvidado, agr.: por voluntad $u$ olvido.]

33 comprar [tach.: $u n$ ] con

35 del pedido [tach.: puede estar tramitando, escrito encima: tramitará por veinte oficinas durante] quince días

37 su marcha [agr.: $o$ no].

38 y siga [tach.: andando, escrito encima: marchando], y

39 llega ela [enm.: la] deseada autorización

45-1 (pág. 153) en otra [agr.: de gran categoría], a la cual

* Pág. 153

4-5 absolutamente [tach.: tranquilos, escrito encima: impunes]; pero

5-6 bien llevados [agr.: desde un punto de vista estético] y la

9 ilustrar [agr.: a Pestalozzi] y a

[ A partir de la línea 11 (pág. 153): Abaratamiento de la, hasta la línea 28 (pág. 156): Olimpio Pitango, se incorporan, en la mayor parte, los cambios que evidencian una versión más cuidada, realizada por Holmberg al publicar parte de esta carta en Fray Mocho, 25 de octubre de 1917].

12 se crea un [agr.: nuevo] impuesto

13 matadero [agr.: ,] y que

14 al [tach.: carnicero, escrito encima: beneficiante]. En vista de tal [enm.: tan, agr.: monstruosa] exacción

iniquidad, [tach.: de tal robo]

15 el costo se [tach.: le] ha

16-17 antes [agr.: de dicho impuesto] se vendían por 50 centavos [agr.: ,] ahora

22 es decir, [agr.: hay] un aumento

24 Monalia [tach.:,] donde

24-25 suburbios [agr.: de todas las ciudades] son [tach.: "erdaderos] jardines

31 Pero [agr.: ,] me dirás

32 Sí [tach.: ,, agr.: ;] todos

35 Es verdad [tach.: ,, agr.: ;]

37 precio [agr.: de venta]

38 y [tach.: aunque] los propietarios 
* Pág. 154

1-2 que sean [tach.: terrenos] pelados [agr.: o vacíos]. Para el fisco [agr.: , en muchos casos,] sería

5 menos completa $\mathrm{x}, \mathrm{x}$, [enm.: etc., etc.] y la

12 sede ministerial [agr.: momentánea], llegué a

14-15 al pedir [tach.: verduras, agr.: legumbres] más variadas

15 papas [agr.: del tamaño de cerezas], me

19 que del puerto salen diariamente [enm.: que salen diariamente del puerto, agr.: a los trenes] y hasta

23 Europa [agr.: ...]

27 duraznos [tach.: hasta] por 3, 4, o 5 pesos [tach.: peras y ma] “y si no le conviene

29-30 enviar a Europa, [agr.: lo cual no impide que vengan cargamentos de Estados Unidos, de Australia y de otros países de Sud América].

31-43 [tach.: Pero; agr. desde: Es indudable sin embargo, que hasta: merma en la producción]

$43 \mathrm{La}$ mejor [tach.: carne] del país

43-44 europeos [agr.: especialmente Inglaterra] y ahora hay

44 pensar en las [tach.: altera] modificaciones

* Pág. 155

1-5 [agr.: (Debo abrir, Toribio, aquí, un pequeño paréntesis. Si tuvieras la mala idea de publicar esta carta en Monalia, debes hacer notar que aqui se justifica el sacrificio de las vacas porque a cierta edad ya no deben producir, y el de las vacas jóvenes, porque se llaman terneras, vaquillonas, etc. y no llevan el nombre de vacas).

6 (pág. 155) - 25 (pág. 156) [agr. desde: El consumo, hasta: al úrtimo con l'uva, se consignan a continuación los siguientes cambios de este agregado:]

6 El consumo de [tach.: la carne de] animales

9 se consumían [agr.: ...]

11 productivas [agr.: (relativamente)]

11-12 alimentación [agr.: $y$ la rapidez del crecimiento]

13 toda la carne [agr.: lo] es [tach.: insípida].

14 los alimentos? [agr.: ...]

16 Es insípida [tach.: Naturalmente, escrito encima: Claro está], y eso porque

17-18 aromáticos que [escrito encima de una palabra ilegible: existen] en las

18 el toronjil [agr.: o melisa] y tantas otras [tach.: yerbas, agr.: hierbas]

19 sino virutas [tach.: insipidas] sin sabor

19-25 y sin olor [agr.: como los llamados "pastos fuertes o duros", hasta: mil o dos mil liebres en un campo.]

28-29 los horneros [agr.: los churrinches, las tijeretas,] las ratonas 
[agr.: las calandrias] y muchas otras

29 tabla rasa [tach.: de las plantas] de los tomates

30 son [tach.: vilmente, agr.: violentamente] asesinados

32-33 servicios en [tach.: los] jardines [tach.: de Inglaterra, agr.: de paises donde saben apreciarlos]

34-35 ratona [agr.: o tacuarita]

35 crisomélidos [tach.: destrozan, agr.: destruyen]

39 vizcacheras, [tach.: el] azote

41 frita [agr.: o saltada]

41-42 ha dictado [tach.: un reciente, agr.: recientemente $u n$ ] decreto

*Pág. 156

5 debería efectuarse [agr.: por reincidencia, tach.: cuando el cazador no pudiera responder con dinero].

6-7 de cumplirla [tach.: una prisión con trabajo servil, agr.: una breve prisión con trabajo equitativamente distribuido.]

7-8 Una [enm.: $L a]$ revisión

8 los trenes [tach.: de regreso] y una multa

11 [tach.: Todo esto y mucho más me dicen personas entendidas.]

17 siendo él muchacho [tach.: habia, escrito encima: existia] en su barrio [tach.: una, escrito encima: la] pulpería

18 de fortuna [tach.: como] suficiente como vino

19-20 proporcionada por el [enm.: la, tach.: vino falsificado] venta de

21 porteños de [tach.: buena, agr.: antigua] familia

24 trivial [agr.: $y$ muchos elogios]

32 XI [err.: XIII]

34 [agr. al título: Cien volúmenes de firmas. Olimpio Pitango es llamado a Monalia. Su recepción. Si vis pacem para bellum. Pitango Embajador]

38 que la mujer [enm.: las mujeres] ha [err.: han] tenido [agr.: siempre] en el

* Pág. 157

5 amor a la patria [tach.: la paz].

11 es [agr.: hoy] el Doctor

21 hasta las [agr.: fulguraciones casi místicas] del dominio

* Pág. 158

4 Bergman, Dufrénoy [enm. ilegible la primera versión]

10 como Linneo, lloraba [tach.: como Linneo, escrito encima: desconsolado] a los

* Pág. 159

3-4 había sido en la [tach.: difícil] interpretación

5 Hooker [agr.: de Endlicher, de Willdenow], de Linneo 
6 a los [tach.: veintitrés] 23 años

10-11 traídas quizás [enm.: quizá, agr.: de lejanos mares], a nuestras

19 para no [tach.: recordar] mencionar

20 Homizo [tach.: descubridor del] fundador del

* Pág. 160

2-3 ingenieros [agr.: y mecánicos entre los cuales, para no citar sino aquellos cuya obra es políticamente ostensible, se destacan los de] ferrocarriles

14 de nuestros [tach.: imperio, escrito encima: dominios] domésticos

20-21 sólo quererlo, [tach.: y provocando asi] y fomentando así las [enm.: la, tach.: fuentes de la discordia, escrito encima y tach.: disidencias, agr.: discordia] que serían [enm.: sería] la ruina

22-9 (pág. 161) [agr. desde: Por otra parte, hasta: luchar sin objeto?, con los siguientes cambios:]

22 debilitándolas [enm.: debilitándola], nuestra

25 contemplación de [tach.: cuadros, escrito encima: escenas] de discordia, [tach.: o de] cuando

\section{* Pág. 161}

1 la nación [tach.: Señores Convencionales], en

5 doméstico [tach.: de aspiración] en el que

6 sociales, [tach.: sólo] no tengan [agr.: más tarde] otros

8 La lucha, [agr.: toda vez que tenga un fin, un objeto], es la ley

10 [tach.: Y puesto, escrito encima: Mas ya] que

12-13 venimos a [agr.: dar] agradecer [enm.: gracias, agr. por] esa [enm.: su] gentileza

17-18 renunciamos [agr.: a la satisfacción] de que

19 que sólo deseamos [enm.: desearíamos, agr.: sin exigirlo] ver

19-20 derechos electorales [agr.: de la mujer] no van [err.: fueran] acompañados

21 sino que quedan [err.: quedaran] abandonados

22 esta manera [tach.: quedan, escrito encima: se] salvaguardados [enm.: salvaguardan]

23 social, [agr.: se] conjurados [enm.: conjuran] los peligros

24 y [agr.: se] salvado [enm.: salva] el principio

27-29 y metafísica [agr. desde: que es la que en otros países, hasta: de nuestra conciencia].

31 con toda [enm.: todo, tach.: consideración, escrito encima: $e l]$ aprecio

32 Molenia, Octubre 15 [agr.: de 1912, err.: 1913].

* Pág. 162

2 deleite [agr.: futuro] para los

9 surtas en el [tach.: puerto, escrito arriba: golfo], impelidos 
22 el 28 de Febrero [tach.: ?, agr.: de 1913?, err.: 1914]

25-26 momento [agr.: en] que recibió [tach.: en Buenos] el telegrama 29 [tach.: Cuando, agr.: Una vez calmados] el deseo

30 de afecto [tach.: quedaron calmados], se puso

31-32 casa de [agr.: dicho] Gobierno

36-37 extrañaron que [tach.: ciertos, escrito encima: algunos] nombres, [agr.: en otro tiempo habituales],

* Pág. 163

3 entrar en [tach.: materia, escrito encima: vereda]

5 y por lo [tach.: mismo, escrito encima: tanto] más

13 momento. [agr.: Eres un Prometeo aconsejado por el Océano]

14-15 invenciones [tach. ilegible] de Cachimbo [agr.: Pérez] y de Botijo [agr.: se] han

17 inaplicable en los momentos actuales, [enm.: la actualidad] de la política

18-24 [agr. desde: Y aunque ridiculos, hasta: temperatura de rojoblanco, con el cambio siguiente:]

18-19 por su tipo [agr.: los] has [tach.: creado, escrito encima: hecho] respetables

27-28 las grandes [tach.: $y$ ] reformas

32 Lee este [agr.: corto] discurso

32- 33 Albarda [agr.: pronunciado en la, tach.: última, escrito encima: primera] sesión [tach. ilegible, escrito encima: reservada] de la Convención

34-1 (pág. 164) la seguridad de la patria [enm.: Patria] exigía

* Pág. 164

4 y lo [agr.: que] quizá

5-6 grito estentóreo [tach.: solamente comparable con El Grito de Ipiranga]

7 regenerada y [tach.: moderna, escrito encima: actual, tach.: $y$ que el Diablo, si quiere, se cargue luego con Botijo y con Cachimbo Pérez!]

9 Gobierno Central [agr.: y los demás concurrentes]

15 fecha de hoy, [agr. y tach.: primer, escrito encima: segundo] aniversario

19-20 inmediatamente en [tach.: un dilema] acción pública

21-22 y que, con [tach.: una sola, escrito encima: raras] excepción

[enm.: excepciones]

22 que escribir [tach.: un] libro [enm.: libros] que

30-31 grave, [agr. que me considerará loco de remate y me dejará en paz], pero imponente [agr.: $y$ ] necesaria [tach.: $y$ fecunda] para

3515 de Enero de este año [err.: del año pasado]

* Pág. 165

11 con el de los [tach.: documentos, escrito encima: antecedentes] re- 
lativos a [enm.: relacionados con]

12 el plebiscito del 15 de Enero [err.: 1 de Junio] resolvió la cuestión

13-14 he vivido [agr.: tranquilamente] en Buenos Aires

15 Argentinos [tach.: $y$ en particular los porteños] a descubrirnos

21-22 reformas políticas [agr.: internas] no consistirán

26-27 riquezas de [tach.: sus, escrito encima: nuestras] montañas

28 Las naciones [tach.: europeas, escrito encima: que usan otros, tach.: idiomas], en su gran mayoría

33 admirable [tach.: de, escrito encima: $e n]$ la distribución

36 de comparación [agr.: de sincronismos] con el Sur

38 Gondwana que [tach.: contenia ambas, escrito encima: abarcaba las dos] regiones

* Pág. 166

4 quien [tach.: aconsejó, escrito encima: señaló] a Ciprio

5-6 porque la leí [tach.: antes que ustedes] primero

7 -iQué hombre [agr.: eres Olimpio, tach.: que hombre!] nada

11-12 lo estabas [tach.: no seas cruel en repetirlo, escrito encima: no lo menciones,] porque

12-13 nos recuerda que [tach.: nosotros estábamos tontos, escrito encima: no hemos sido suficientemente sagaces].

17 Vas a [tach.: tratar] celebrar [agr.: ad referendum] un tratado

19-20 el mismo origen, [tach.: casi] las mismas necesidades

23 las diversas [tach.: ramificaciones, escrito encima: ramas] de un

24 Gobierno [tach.: unit] republicano-[tach.: unitario] democrático

25-26 hombres [agr.: de pelea] perfectamente disciplinados [tach.: fábricas, escrito encima: usinas] de elementos bélicos

32 suelo nativo [tach. lect. dud.: caminas, escrito encima: te yergues] sobre

33-19 (pág. 167) [agr. desde: -Sí! —exclamó Olimpio, hasta: gota de sangre viva, con los siguientes cambios:]

34 vecinos aliados [agr.: cuando quieren], saben

36-37 Existe un [tach.: gran] peligro [agr.: enorme] para [agr.: la libertad] de las naciones

38-39 actos a los [agr.: cuales la] generalidad [agr.: superficial] no

* Pág. 167

7 de riqueza, [tach.: además] sin contar dentro

8-9 más afectuosas y más [tach.: sólidas, escrito encima: profundas] que]

10-11 sin dobleces [tach.: empleando la convicción de un francés, por-

11-12 sugestión [tach.: de la, agr.: que ellos no han sabido pesar], porque

14 y si con Drago [err.: Roque Sáenz Peña] debemos exclamar

20 XII [err.: XIV] 
$21 \mathrm{El}$ alma [agr.: de las repúblicas] sudamericanas

25 tratados [tach.: secretos] una vez

26 constituido [agr.: en forma] de acuerdo

26-27 Constitución [agr.: y proyectada y aprobada, tach.: que, escrito encima: por] los convencionales [tach.: habian]

29 la actitud [agr.: anterior] del mismo

* Pág. 168

1 explicada [tach.: por] no sólo por [tach.: que] el éxito

3 camino más corto [agr.: Y más seguro] suele ser el [tach.: más] de los medios

10 hubiese continuado con su propaganda incansable [enm.: continuado incansable con su propaganda] respecto

21 juicioso, [tach.: $y$ ] progresista y democrático

* Pág. 169

1 se atreviera a [tach.: realizarlos, escrito encima: proponerlos] o a aceptarlos [agr. $y$ tach.: El Tarpeyo era la salvaguardia de la moral patriótica]

2 seguridad [tach.: del país, escrito encima y tach.: de la Nación, agr.: de la patria], y esa visión

4-5 como un [tach.: roce, escrito encima: susurro] de alas

18 morisqueta [tach.: de] carnaval [enm: carnavalesca]

19 confraternidad [tach.: universal, agr.: internacional], todavía

19-20 pasaban [agr.: por los aires] las nubes [agr.: de humo] de [agr.: la] pólvora

21-22 de Orange, [agr.: del Egipto], de la Manchuria,

Port-Arthur [agr.: $y$ de la Rusia]; tronaba

23-24 Marruecos [tach.: $y$ ] en Trípoli [tach.: $y$ ], en el [tach.: Congo, agr.: Archipiélago griego, en los Balkanes]; y sobre los

26-27 mercaderías, [agr.: y en particular de las aspiraciones más o menos solapadas de la alta Banca], porque

29-31 ley natural [agr.: del hombre, de la lucha por la vida, y] del triunfo de los más aptos, [agr.: cualesquiera que sean los instrumentos que esa lucha pueda poner en juego.]

35 de garras, [agr.: que es cuando no sirven para nada; él no

* Pág. 170

2 hispanoamericanas [tach.: tenían] eran

5 ínfulas de [tach.: mestizos, escrito encima y tach.: híbridos, agr.: republicanos]

de libertad [agr.: $y$ democracia] mientras

9 asesinos inmundos de [agr.: cepo y de] látigo [tach.: y cepo]

11-12 autoridad seculares [enm.: secular] ejercida sobre almas primitivas [agr.: a las] que [agr.: no] habían

13-14 de los candiles [tach.: dándoles, escrito encima: conservándolas 
bajo la influencia] de un terror

26-27 derechos del ciudadano, [tach.: comenzando por la dignidad militar], que sólo podía ser juzgada [err.: juzgado] por tribunales civiles

30-31 los monalitas, [tach.: por el, sigue una palabra ilegible] ( por el proyecto de [tach.: retardarlo] reciprocidad)

31 ejércitos [tach. ilegible] Oriental

33-29 (pág. 174) [agr. desde: Sin embargo, hasta: el prócer de Monalia, con los cambios siguientes:]

33 en un objetivo solo [enm.: en un solo objetivo]

* Pág. 171

3 de una inmigración [agr.: sin limites.]

6-7 clases inferiores [agr.: continuaba reinando; pero hubo] un momento

13-15 el cuadro del servilismo [tach.: actual] bajo el dominio del español, [tach.: con las pinceladas de una era futura] con el que se ofrecía para el porvenir y cuyas pinceladas [tach. ilegible] llenas de esperanzas [tach.: $y$ promesas] de luz

17-18 colectivas [tach.: el triunfo, escrito encima: la victoria] del pueblo y [agr.: por la tanto] la democracia triunfante.

24 continuó [agr.: siendo] ejercida

30 de venganza [tach.: contra] que entronaban

34 demasiado poder para que [agr.: los pueblos] aprendiesen

* Pág. 172

12 desaparecer los [agr.: últimos] hedores

16 en el [tach.: Interior, escrito encima: Centro], en el Litoral

20 La Patria [tach.: tenía] tuvo entonces

24 que permite a los [tach.: pueblos, escrito encima: gobernantes] levantar una iglesia donde [tach.: falta una] todavía falta

29--30 no existen [tach.: propiamente, escrito encima: realmente] los partidos

32 sino [agr.: en] el sentido

* Pág. 173

7-8 del acto [agr.: que se] realizado [enm.: realiza] por delegados de los [tach.: partidos] diversos

9-16 [este párrafo final fue tachado y luego Holmberg escribió al costado un signo de pregunta, se ha dejado en el texto porque encaja con todo el pensamiento anterior, va desde: pero la anulación de una o más de éstas hasta: $y$ la nueva ley transforma en un deber]

17 [tach.: En estos días] La elección

17-18 a los radicales [agr.: con la mayoría] y a los socialistas [agr.: con la minoría]

19 la pureza [tach.: del voto] de una elección

20-21 los elementos principales que lo [tach.: constituyen, escrito en- 
cima: forman], es un partido constitucional.

23 Los socialistas no. [tach.: El grito] Su grito

30-31 de la constitución [agr.: en su forma y en su esencia, quitándole todos los fundamentos tradicionales que la han inspirado.]

33 En las elecciones del 30 de Marzo de este año [err.: de este año] de 1913 ,

* Pág. 174

7-8 ya que [tach.: se empeña en] aspira a que

8 y así [tach.: podré, agr.: me sera posible] dispersarlo

17 durante [tach.: esos diez] ese tiempo

30 XIII [err.: XV]

32-33 sociales, [tach.: $y$ ] económicos

34 de fundamentos [agr.: accesorios] en tiempos

* Pág. 175

1 Estados Unidos [agr.: del Norte] y otros

12 rápidas y [tach.: legítimas, escrito encima: limpias], las dos cámaras

16-17 la religión, [tach.: $y$ ] el divorcio [tach.: $y$, agr.: el voto, $y$ la elección del Presidente. Por haberse agregado la elección del Presidente posteriormente, con otra tinta, Holmberg olvidó desarrollar esta otra diferencia de la constitución de Monalia].

18-19 Libertad absoluta de cultos, [agr.: lo que excluía la necesidad del patronato y de la representación oficial de (tach.: ninguna, escrito encima: cualquier\}] iglesia.

22-24 de todos los Códigos [tach.: las faltas o crímenes, escrito encima: ninguna falta ni crimen] vinculados de algún modo con la Religión [tach.: serían motivo tratado en, escrito encima: en concepto de alguien podían ser tomados en cuenta en el] Código Penal.

26-27 [agr.: A los desgraciados que de él caían al mar se les atribuía un "descuido" en otros países los designaban como "resistidos"].

31-35 [agr. desde: En cuanto al voto, hasta: se aceptaría calificado].

36 [tach.: Por otra parte] El texto de

39 no están publicados [tach.: Hecho interesante y curioso: el Código Agrario se ha confiado lo redacta Olimpio Pitango].

40 de plata [agr.: de cobre, de plomo] de carbón

41-3 (pág. 176) a la Nación [agr.: asi como las cantidades que ésta necesita de los otros usuales.] Los otros metales y las piedras preciosas no [agr.: excepto los diamantes necesarios para obras públicas de perforación.]

* Pág. 176

4 Pero [tach.: algunos, escrito encima: los] extranjeros

5 caerse [agr.: por casualidad] desde el

15 fuera jurada el [tach.: 10 de Marzo, escrito encima: 20 de Abril], 
fecha que se [tach.: creaba, escrito encima: adoptaba] como de

21 Los poetas, los [tach.: músicos] artistas,

* Pág. 177

2 Tarpeyo [tach.: (en construcción)] a los que

3 predilectos [agr.: aunque de menor cuantia,] difamaron

7 se debía [tach.: al, escrito encima: a algún] espíritu práctico [tach.: de Claudio Moloso.]

17 ejercicios doctrinales [tach.: $y$ aún de simulacros, escrito encima y tach.: inclusive los]

25-26 género [agr.: de mamíferos] provisto de colmillos

29-31 internacional militar. [agr.: Y es claro: la guerra es una brutalidad en acción; pero el militar es un altruista y casi siempre una víctima.]

34 En la madrugada del [tach.: 20 de Diciembre, escrito encima: 15 de Octubre], la Capital

* Pág. 178

3 sus armas y bagajes [tach.: cuando Guillermo lo supo envió a Monalia sus embajadores]

7-8 su alianza [agr.: dentro de una disciplina perfecta incubada por un patriotismo generoso.]

13-25 (pág. 179) [agr. desde: Aunque Monalia, hasta: humanamente posible, con los siguientes cambios:]

13 defensa [agr.: nacional] con todo

20 con permiso [agr.: en uno de sus puertos] los marineros

27 leyes propias [agr.: de su Nación] juzgaban

29-30 su gobierno [agr.: pues él no podía resolverlo sino por las leyes nacionales] y esperaba

38-39 contaba con el [tach.: formidable] farallón del Sur [agr.: mucho] más

* Pág. 179

6 ejecutados como [tach.: ensayos] ejercicios

15 y los [agr.: medios] de transporte

20-21 y posibles. [tach. palabra ilegible, escrito y tach.: Pero] Por el mar

* Pág. 182

6 y ahora [tach.: conocemos, escrito encima: observamos] otro

31 a la concurrencia [agr.: desde el escenario] como lo

35-8 (Pág. 183) [desde: para los grandes, hasta: $y$ se retiró, este final del capítulo, que corresponde a la pág. 171 del manuscrito, fue escrito en la página enfrentada]

* Pág. 183

$9 \mathrm{XV}$ (Final) [err.: XVI] 
10 La Princesa Rayo de Luz [agr.: (Cuento)] dijo:]

12-15 [agr. desde: La fiesta estuvo brillante, hasta: dirigiéndose a ellos,

20 su hijo [agr.: llamado Picaflor,] muy

30 cuarenta y [tach.: tres, escrito encima: cinco] y la reina

35 corrió por [tach.: todo] el mundo

40 unas cruces [agr.: o estrellas] muy hermosas

41 de [tach.: 18 , escrito encima: 14 ] kilates

* Pág.: 184

7-8 Gran Canciller [agr.: y con el Gran Chambelán] sobre asuntos

11 comunicaciones a sus [tach.: mandatarios, escrito encima: comitentes

18 remitieron [tach.: sendas páginas, escrito encima: innumerables pliegos] declarando

20 los Reyes y los [tach.: Embajadores] Emperadores

21 torciera el [agr.: mismo] taco como

27 frecuente con sus [tach.: mandatarios, escrito encima: monarcas], y

37 la sed [tach.: sin excluir, escrito encima: reservando] un rinconcito

41 la [agr.: gran] copa de oro

42-44 Reyes y Embajadores [enm.: Emperadores] que nos han enviado [tach.: $a$ ] sus mejores ministros para que estudien [agr.: secreta $y$ ] profundamente llenar.]

45 - y vació la [agr.: gran] copa de oro, [agr.: que su copero volvió a

*Pág. 185

5 Emperador, [agr.: y vació la gran copa de oro, que su copero volvió a llenar.]

$8 \mathrm{ni}$ el de sus [tach.: mandatarios, escrito encima: monarcas] que conocen

9-10 comunicaciones; ..." y [agr. y tachado: bebió, agr.: vació la gran copa de oro que su copero volvió a llenar]

13 signo doméstico [agr.: y burgués] se refería al colosal

14 tamaño de su copa [agr.: de oro] que vaciaba

17 él [tach.: el] dijo [agr.: a la Reina en voz baja] que continuaría hablando

18 el gran Chambelán [tach.: se levantó para] que sabía traducir

21 fuera opaca [agr.: y no estuviese llena; toma una

25 contra el [tach.: protocolo, escrito encima: ceremonial, Señor] - dijo

26 con el [tach.: protocolo, escrito encima: ceremonial!] — dijo

29 - "El [tach.: protocolo, escrito encima: ceremonial] te lo

30 - iAl Diablo el [tach.: protocolo, escrito encima: ceremonial!] - dijo 
33 En [tach.: ese, escrito encima: el] mismo

37 de terciopelo [tach.: de] carmín

$40 \mathrm{y}$ una [tach. ilegible, escrito encima: pluma] blanca

* Pág. 186

2-3 en la gloria, [agr.: en la juventud] en el amor

4 las almas [agr.: de los oyentes] que

6 surgían [agr.: combinaciones nuevas] como rayos

9 decidido, [tach.: terminante,] categórico

12 aplaudieron [agr.: después]. Las damas

16 lo prohibe [tach.: el protocolo, escrito encima y tach.: ceremonial, agr.: la etiqueta]

17 el [tach.: protocolo, escrito encima: ceremonial], - dijo

21 al copero, [agr.: el cual le hizo notar que se la habia llenado a escondidas], y poniéndose

23-24 devolvió al Rey la [agr.: gran] copa de oro

34 Los [tach.: Ministr] Embajadores

36 no tiene [agr.: visibles ahora] más pimpollos [tach.: ahora] que

37-38 que la [enm.: las, tach.: Princesa] mejillas de la Princesa se [tach.: pusieron rojas, escrito encima: pusieron encendidas], como

39 un caso de Lola-Ruk! [enm. sobre una palabra ilegible] —observó

41-42 potencia sugestiva tan [tach.: poderosa, escrito encima: grande] que

43 y sin embargo, [tach.: todos] continuaban

* Pág. 187

2 que los [tach.: querubines, escrito encima: ruiseñores] coreaban

6-7 el contenido de la [agr.: gran] copa

11-12 los médicos [tach.: no sabían, escrito encima: ignoraban, tach.: que era] lo que

29 bailó de alegría. [tach.: y fue a la corte. Cuando]

* Pág. 188

12 y eso que [tach.: esa, escrito encima: $t u$ ] Reina

13 ahora pesas [tach.: $d o$ ] 200.

23-24 con las mujeres [agr.: $n$ i hacerlas entrar en razón]

30-31 no dudaba [agr.: de] que a fuerza

32-33 el cual experimentó una [enm.: un] violento

36 tener en cuenta que el [tach.: protocolo, escrito encima y tach: ceremonial, deja: protocolo] se lo prohibe

39 [tach.: Por otra parte, escrito encima: El caso es que] Diamela

* Pág. 189

3 un pimpollo [agr.: en] la noche

4 [agr.: Sin decir una palabra] el trovador 
5 arrobadora, [agr.: única,] celestial, [tach.: única] cantó:

6-13 [Holmberg hizo la siguiente indicación al margen de esta octava: "tipo más chico"]

8 para [tach.: $e l$, escrito encima: $u n$ ] hombre

9 gloria y amor y fortuna

[tach.: Sin tí que valen honores]

16 y acercándole [enm.: acercando] la cara

23 el laúd, [agr.: y golpeando el suelo con el taco $y$ ] pellizcando

24 distintos modos [tach.: rudos, escrito encima: violentos] estaba

29 a ese sonido traidor [escrito inmediatamente después de este verso: -Diamela, S. M. el Rey, tu Augusto Padre, te llama]

* Pág. 190

2 lesa majestad [agr.: no lo dudes]. Pero tú no eres [agr.: el] culpable.

12 la gracia [tach.: del, agr.: que el] Rey [tach.: y el honor que] me

14 nunca jamás, [tach.: $m e$ ] habría [tach. ilegible] tenido

16-17 Príncipe [agr.: Rayo de Sol] de Sichinta

17 de Calamina [tach.: Emperador, escrito encima: Rey] supremo

20 la cabeza [agr.: también]. El Rey

23 quince días, [tach.: vinieron] asistieron

24 medallas [agr.: conmemorativas] de cobre

24-25 de oro de 18 [enm.: 14] kilates

$28 \mathrm{La}$ [tach.: cuentista, escrito encima: narradora] fue

36 encarnación del [tach.: último, escrito encima: más alto] progreso [agr.: político]; se extinguen

38 la razón las [tach.: abomina, escrito encima: excluye]; pero

38-39 la flor [tach.: soberana, escrito encima: inmarcesible] de la

40 las [tach.: potencias, escrito encima: energias] motrices

* Pág. 191

3-4 Beethoven, [agr.: Perrault y La Fontaine] -sombras [tach.: inmortales] augustas

[En la página enfrentada a la 18 del cuento, Holmberg escribió el siguiente párrafo que luego tachó:

Y sobre todo esto, Señora, Señores, y en particular Señor Presidente de la República de Monalia, preocupémonos de los hombres que tienen ideas; fomentando su actividad, con todos nuestros recursos, porque ellos son los que representan las fuerzas vivas, las fuerzas motrices del engrandecimiento de las naciones. Los psicólogos puros, que tantas veces nos han descarrilado a causa de imperceptibles desviaciones de una lógica más o menos elástica, nos han enseñado para siempre, sin embargo, que existe en el Hombre una entidad trinitaria, soberana, omnipotente y gloriosa, la que lo habilita para sentir, la que lo habilita para pensar la que lo habilita para querer: sentimiento, pensamiento y voluntad -el alma toda del individuo el alma toda de la Humanidad.] 
8-13 [tach. y luego lo deja, desde: Y algunos lloraban, hasta: es mi madre!]

14-9 (pág. 192) [agr.: desde $Y$ entonces, hasta la edad de tres años, última página del manuscrito, muy deteriorada por carecer de contratapa este cuaderno borrador, de letra manuscrita irregular cuyos caracteres difieren de la cuidada caligrafía inglesa presente a lo largo del texto, Holmberg la escribió probablemente después de la terminación de la novela. Hay luego cuatro renglones ilegibles]. 


\section{ÍNDICE \\ DE PALABRAS Y EXPRESIONES ANOTADAS}

\author{
Abram, 137 \\ ad referendum, 166 \\ alcaraván, 143 \\ Alcibíades, 118 \\ Alejandro, 109 \\ Amazonas, 123 \\ "América para el \\ mundo entero", 167 \\ Aníbal, 109 \\ Antíope, 125 \\ Apolo, 139 \\ Apuleyo, 82 \\ Aquiles, 128 \\ Ariadna, 125 \\ Arístides, 117 \\ Aristófanes, 82 \\ Aristóteles, 138 \\ Arquímedes, 142 \\ Aspasia, 127 \\ Astete, 136 \\ Athena, 126 \\ atlantes, 104 \\ Ayacucho, 171 \\ Baltasar, 124 \\ Basaldúa, 104 \\ Bayardo, 128 \\ Beaumont, 158 \\ Belgrano, 133 \\ Bellini, 191 \\ Belona, 126
}

\author{
Bentham, 159 \\ Bergman, 158 \\ Boccaccio, 82 \\ Broca, 135 \\ Brongniart, 158 \\ cabeza, 136 \\ Carlos I, 124 \\ Carlos II, 124 \\ Catalina II de Rusia, 124 \\ chalitas, 73 \\ Champollion, 142 \\ China, 134 \\ claqueur, 97 \\ Comte, 131 \\ Confucio, 134 \\ consejo de Océano, 132 \\ Constantino, 115 \\ Constitución, 172 \\ contratos leoninos, 168 \\ Corneille, 163 \\ Cornelia, 127 \\ Cristo, 137 \\ Cromwell, 125 \\ Cuvier, 160 \\ D'Artagnan, 128 \\ Darwin, 138 \\ Daudet, 150 \\ De Candolle, 159 \\ Demóstenes, 130
}


Diamela, 187

Dickens, 83

dinastía de los Incas, 133

dinastía de los manchúes, 135

Donizetti, 191

Donnerwetter, 98

D'Orbigny, 158

Dorrego, 133

Dufrénoy, 158

eczema circular, 136

ejércitos germánicos, 160

Endlicher, 159

Enrique III, 115

Esquilo, 132

Federico el Grande, 125

Fedra, 125

Fenelon, 137

Fernando de Nápoles, 121

Fidias, 84

filología, 78

Francia enlutada, 160

Galileo, 127

Garibaldi, 100

Genghis-Khan, 128

Gladstone, 157

Gondwana, 79

Haüy, 158

Herodoto, 176

Hooker, 159

Hugo, 131

Humboldt, 160

indo-germánicos, 80

inferne, 137

Ingersoll, 139

Isabel de Castilla, 128

Isabel de Inglaterra, 124

Isaías, 120

Juana de Arco, 100

Juana, fundadora [...]

de la silla gestatoria, 127
Júpiter, 115

Jussieu, 159

Karma, 129

Kengott, 158

Krespel, 164

La Eneida, 137

La Fontaine, 191

La Gioconda, 139

Lao-Tsé, 134

Las nubes, 118

laurorum genitrix, 147

Leverrier, 142

Licurgo, 131

L'Immortel, 150

Linneo, 158

Lohengrin, 88

Luis XIV, 125

Luis XVI, 129

Lyell, 158

Magna Carta, 170

Mahabharata, 80

Mahoma, 136

manzana de discordia, 143

Maquiavelo, 130

María Antonieta, 129

María Stuart, 124

María Teresa, 125

Marte, 126

mayorazgo, 101

meleagrinos, 159

Metagitnion, 88

Milón, 99

Minerva, 126

Moreno, 133

Murillo, 84

Mutatio optima, 119

mutilaciones por etimologia, 125

Mutsubito, 135

Nabucodonosor, 124

Napoleón, 109

Napoleón en Arcole, 128

Naumann, 158 
Nemrod, 128

Neptuno, 126

'No sólo de pan, 136

Numancia, 128

Océano, 132

O'Connell, 157

Omar, 146

Paganini, 163

Palas, 126

paleoscópica, 129

palí, 80

papyrognostas, 150

"Paraíso" del Dante, 120

Pelletan, 157

Penélope, 121

Pentesilea, 123

Pericles, 85

Pero Grullo, 102

Perrault, 191

Pestalozzi, 153

petizo, 132

Petronio, 82

Pico de la Mirándola, 153

pitado, 73

Platón, 138

playitas, 168

Plutarco, 157

pólvora, 121

pour la galerie, 176

pracrito, 80

Praxíteles, 84

precursores de Galileo, 137

ptomaínas, 82

Pullman, 118

Quinquendona, 85

Rabelais, 98

radicales, 173

Rafael, 84

Ramadán, 88

Ramayana, 80

Rembrandt, 84

Revolución Francesa, 101
Roentgen, 187

Rosas, 172

Saavedra, 133

Sáenz Peña, 167

Safo, 129

Sagunto, 128

sánscrito, 80

Sarasate, 163

Sardanápalo, 124

Savigny, 131

Schiller, 81

Semiramis, 124

Siete Partidas, 170

sigmatóideo, 147

socialistas, 173

Sócrates, 117

Solón, 111

South America for the South

Americans, 191

Spencer, 157

talweg, 75

Tártaro, 126, 138

teorías filológicas, 78

Teseo, 125

"They say so, but they don't mean it.", 161

Tirteos, 171

Turena, 128

Twain, 82

Vasishthas, 129

Venus de Medici, 139

Virgilio, 81, 137

Voltaire, 82, 157

Wagner, 191

Willdenow, 159

Xenofonte, 157

Ypiranga, 87

Zaragoza, 128 


\section{APÉNDICE}

Se transcribe a continuación la extensa nota explicativa de Holmberg al lector, escrita con letra mucho más pequeña y apreta$\mathrm{da}$, que aparece en el manuscrito en las páginas enfrentadas a las 143,144 y 145 , que permite reconstruir el proceso histórico de la novela y esclarecer su fecha de finalización. Como ya lo apunté en la introducción donde estudio parte de esta nota, un hecho que confirma que la novela no fue concluida en 1913 es que es contemporánea a la iniciación de la primera Guerra Mundial (1914), según lo declara Holmberg aquí:.

Escribí este libro en 1913 y no lo publiqué entonces por cualquier motivo. Por qué lo escribí... Vaya! Tanto valdría preguntar por qué cantan las aves, por qué pican los mosquitos, por qué mojan los escritores su pluma en la tinta.

Me encontraba en la Inspección General de Enseñanza Secundaria, en la misma oficina en que otro Inspector y un distinguido Profesor de Literatura trataban de algún punto del programa. Cómo vino la cuestión, lo ignoro, pero el Profesor refería las peripecias de un cerebro en el cual persistieron las exteriorizaciones del lenguaje parlamentario mucho tiempo después de la cesación de mandato. Lector asiduo de Dickens, de Mark Twain, de Arthemus Ward y de los humoristas de otras naciones, aquella conversación era para mí de un encanto extraordinario. Persona de alta cultura en todo sentido, el narrador exponía sin burla ni encono dando a sus frases solamente la energía que despierta la sonrisa; pero tenía un arte diabólico para acumular intenciones y al final estallamos los tres en una espléndida carcajada. - ¿Me regala, Doctor, esos datos? -le pregunté.

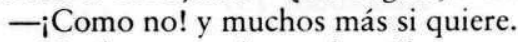

- No, basta con lo que he oído.

Esa misma noche, al regresar a casa, encontré una carta de Carlos Correa Luna: "Doctor, necesito una página suya para Fray Mocho." Claro! Ya tenía el tema y me senté a escribir. ¿Qué cosa? El primer capítulo de 
este libro. Pero eso no era lo que me pedía el Director de Fray Mocho. Había deseado ubicar, localizar al personaje a que antes aludí y el cuadro resultó demasiado grande para él, de manera que en todo el libro no hay una palabra, no hay una idea que recuerde la narración que yo había escuchado. La imaginación, al separarse de las primeras intenciones por las interferencias de una filiación de ideas, compleja y múltiple, me había hecho olvidar el tema. Al cerrar ese capitulo primero, el libro todo estaba bocetado.

No pensaba al terminarlo que habría de publicarse en 1915.

El Drama inmenso, colosal, único en la Historia de nuestro mundo afectado, dolorido y avergonzado, estaba previsto por todos aquellos que siguen con interés las intenciones y no la exteriorización diplomática de pueblos, cuya evolución se sigue con interés porque marchan al frente de lo que hasta ahora llamábamos civilización; pero nadie pensaba que se representase en las proporciones monstruosas que ha adquirido, ni nadie soñaba llegar a contemplar las incongruencias internacionales más monstruosas, aunque constituyen su trama escénica.

Aunque de vieja estirpe militar, odio la guerra porque es la forma de lucha por la vida más brutal y más injusta que ha podido imaginar el mamífero erguido y con cuatro colmillos que se llama Hombre, y cuya exteriorización más elevada, que es la ciencia, se pone al servicio de las naciones para encontrar los procedimientos más eficaces y más crueles de exterminio y desolación; y la física, la química, las matemáticas, que son la gloria del espíritu humano, entregan sus tesoros para ponerlos al servicio de la crueldad.

Si los habitantes de un planeta vecino pudieran observarnos con la misma claridad con que nosotros escudriñamos por el microscopio los organismos que se encuentran a nuestro alcance, quedarían asombrados al comparar la desproporción que existe entre las porciones pobladas y cultivadas del nuestro y lo que aún no se utiliza.

$\mathrm{Al}$ estruendo de los duelos de artillería, sigue el estruendo de las opiniones fundadas en la mosca que pasa o el susurro que no se puede localizar; la base en que se apoyan es la simpatía, pero cuando pasen los siglos en su marcha inexorable y la Historia dé su fallo, volverá a resonar una voz milenaria dirigiéndose a las naciones: "Aquélla de vosotras que esté sin pecado arroje la primera piedra."

Entretanto, los ejércitos en campaña y todas las poblaciones de los beligerantes dedican una parte de su tiempo a dirigir plegarias a Dios por el triunfo de sus armas, y lo hacen en 50 idiomas, convencidos todos de que la justicia está con ellos, y que aplaste, reviente, desmenuce a sus enemigos que también están rezando. Pero todos tienen cañones, fusiles, balas, bombas, metralla, pólvora, lanzas, espadas, bayonetas, naves aéreas, acorazados, submarinos; pero los ejércitos de nuestra simpatía tienen todo esto para dulcificar la situación de los enemigos. Cuando A con 15 hombres en un submarino echa a pique un acorazado de 900 tripulantes de B, 
comete un acto de barbarie, estúpido, feroz; cuando B, con un submarino que lleva 15 hombres echa a pique un acorazado de 900 tripulantes de $\mathrm{A}$, realiza un acto laudable de justicia y de humanidad. $Y$ hay quienes creen que Dios los escucha y va a proceder en consecuencia, siendo así que muy probablemente los 900 de A y los 900 de B ignoran por qué motivo real matan o los matan. Pero dejemos que el tiempo archive los acontecimientos.

Poco antes de la guerra, el Dr. Conan Doyle, actualmente uno de los astros más brillantes de la literatura inglesa, creador de Sherlock Holmes y autor de Neil, El mundo perdido, El crimen del Congo y muchas otras obras en extremo interesantes, publicó en Fortnightly Review un artículo titulado Danger (El peligro). Esta obra es quizá la primera que ha presentado de un modo palpable e imponente la enorme potencia del submarino en la guerra naval. A estas horas el autor debe estar pensando que, no obstante el veredicto de los almirantes y peritos en estos asuntos, favorable a sus opiniones, Inglaterra no se dio cuenta del enorme valor de su alarma.

A los muy pocos días de iniciarse la guerra, los diarios de Buenos Aires publicaron cuadros representativos de los recursos bélicos navales de cinco potencias europeas, $\mathrm{y}$ esos cuadros en que las cinco naciones daban las abscisas y los recuerdos las ordenadas, ofrecían datos numéricos concretos en las coordenadas, menos en una: "Alemania, número de submarinos de tipo ambiguo, 27; de tipo moderno (?)." Llamé a más de uno la atención sobre este dato sugestivo, el interrogante, vinculándolo con la novela de Conan Doyle. Aquí no se trata de simpatías, se trata de juzgar. ¿Es posible dar una opinión eficaz del resultado de un combate naval entre Inglaterra y Alemania tomando en cuenta el coeficiente bélico de sus naves descubiertas? Sí. ¿Es posible hacer lo mismo mientras ese interrogante no se convierta en cantidad concreta? No.

La terminación de la guerra en Europa devolverá por algún tiempo a sus hogares a los sobrevivientes, porque en realidad no se trata de que Alemania se quede o no con Bélgica y con Polonia, o Rusia con una parte de Austria, o ésta con una fracción de los Balcanes o de Rusia, o Inglaterra con Egipto y Chipre, o que Francia recupere Alsacia y Lorena y vaya o no a Berlín, ni Alemania a París... Se trata del dominio del mundo entero y en el mundo está Monalia. Olimpio Pitango había seguido "con interés las intenciones y no la exteriorización diplomática" de las potencias. Había previsto un peligro. Es de desear que por honor de las naciones no tenga realidad la previsión de Olimpio Pitango.

No se crea, sin embargo, que la guerra actual haya influido en lo mínimo en la redacción de este libro, cuyo primer capítulo fue leído en una fiesta de los estudiantes de la Facultad de Ciencias Exactas, Físico Matemáticas y Naturales; y el último en ... una fiesta a beneficio de la Escuela graduada de la localidad. Si el autor escribiera un libro influenciado por la actual guerra, su principal personaje hablaría de otro modo, porque Olimpio Pitango es épico y conoce a Esquilo y a Prometeo. 


\section{ÍNDICE}

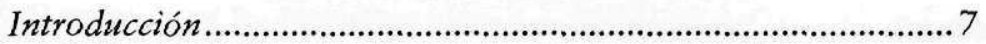

Contexto histórico del texto .........................................

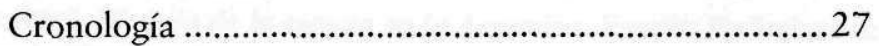

Olimpio Pitango de Monalia ...............................................30

Visión carnavalesca de un mundo al revés ........................32

Fijación del texto crítico ....................................................55

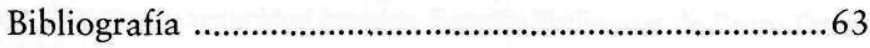

Olimpio Pitango de Monalia ........................................................71

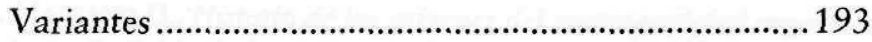

Índice de palabras y expresiones anotadas...................233

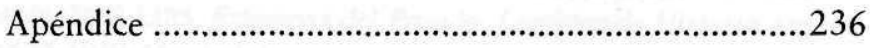




\title{
BIBLIOTECA \\ "DIMENSIÓN ARGENTINA"
}

\author{
dirigida por \\ GREGORIO WEINBERG
}

\section{Títulos publicados}

Alberdi, JuAN B., Fragmento preliminar al estudio del Derecho. Estudio Preliminar de Bernardo Canal Feijoo. (Agotado)

ARLT, ROBERTO, Nuevas aguafuertes porteñas. Estudio preliminar de Pedro

G. Orgambide. (Agotado)

BABINI, JosÉ, Historia de la ciencia en la Argentina. Estudio Preliminar de Marceio Montserrat.

Bagú, Sergio, Argentina 1875-1975. Población, economía, sociedad. Estudio temático y bibliográfico. (Agotado)

Baigorria, Manuel, Memorias. Prólogo de Félix Luna y Cronología razonada de J. A. de Diego.

BARROS, ÁlVARO, Fronteras y territorios federales de las pampas del sur. Estudio preliminar de Alvaro Yunque. ( $2^{a}$ edición)

- Indios, fronteras y seguridad interior. Estudio Preliminar de Pedro Daniel Weinberg

BEAUmont, J. A. B., Viajes por Buenos Aires, Entre Ríos y la Banda Oriental. Estudio Preliminar de Sergio Bagú. Traducción y Notas de José Luis Busaniche. (Agotado)

BOSCH, MARIANO G., Historia de los orígenes del teatro nacional argentino y la época de Pablo Podestá. Estudio Preliminar de Edmundo Guibourg. BURgin, Miron, Aspectos económicos del federalismo argentino. Estudio Preliminar de Beatriz Bosch. Traducción de Mario Calés. ( $5^{a}$ edición) BuSANICHE, José LuIS, Estampas del Pasado. Lecturas de Historia Argentina. 1527-1910. (Agotado)

- Historia Argentina. Advertencia Preliminar de Gregorio Weinberg. ( $8^{a}$ edición)

Cancionero tradicional argentino. Recopilación y Estudio Preliminar, Notas y Bibliografía de Horacio Jorge Becco. (Agotado) 
Coni, Emilio A., El gaucho. Estudio Preliminar de Beatriz Bosch. (2 ${ }^{a}$ edición). Correspondencia entre Rosas, Quiroga y López. Recopilación, Notas y Estudio Preliminar de Enrique M. Barba. (2a edición)

ChIARAmONTE, José CARLOS, Nacionalismo y liberalismo económicos en Argentina, 1860-1880. (2 $2^{a}$ edición)

DENIS, PIERRE, La valorización del país. La República Argentina - 1920. Traducción, Estudio Preliminar y Notas de Elena Chiozza.

DORFMAN, ADOLFO, Historia de la industria argentina. ( $2^{a}$ edición)

- Cincuenta años de industrialización en la Argentina. 1930-1980. Desarrollo y perspectivas

Drama rural [El]. (Barranca abajo, de Florencio Sánchez; La flor del trigo, de José de Maturana; Madre tierra, de Alejandro Berruti; Las víboras, de Rodolfo González Pacheco; El guaso, de Alberto T. Weisbach; Los afincaos, de Enzo Aloisi y Bernardo González Arrili). Estudio Preliminar de Luis Ordaz. (Agotado)

EbÉLOT, AlfRED, Relatos de la frontera. Traducción de V. D. Bourillons. Estudio Preliminar y Notas de Alicia Carrera. (Agotado)

Elflein, Ada María, De tierra adentro, Cuentos y tradiciones. Estudio Preliminar de Julieta Gómez Paz. (Agotado)

FAlKNer, P. TOMÁs, Descripción de la Patagonia y de las partes contiguas de la América del Sur. Estudio Preliminar de Salvador Canals Frau. Traducción y Notas de Samuel Lafone Quevedo. (2 ${ }^{a}$ edición)

FERNS, H. S., Gran Bretaña y Argentina en el sigo XIX. Traducción de Alberto Luis Bixio. ( $5^{\mathrm{a}}$ edición)

Fontana, Luis Jorge, El Gran Chaco. Estudio Preliminar de Ernesto J. A. Maeder.

FragueIro, Mariano, Cuestiones argentinas y Organización del crêdito. Estudio Preliminar de Gregorio Weinberg.

Franco, LuIS, El general Paz y los dos caudillajes. Estudio Preliminar de David Viñas. (Agotado)

Gaignard, Romain, La pampa argentina. Ocupación, Poblamiento, Explotación. De la conquista a la crisis mundial. 1550-1930.

GÁlVEZ, MANUEL, Recuerdos de la vida literaria:

Tomo I, Amigos y maestros de mi juventud. (Agotado)

Tomo II, En el mundo de los seres ficticios. (Agotado)

Tomo III, Entre la novela y la historia. (Agotado)

Tomo IV, En el mundo de los seres reales. (Agotado)

GERCHUNOFF, ALBERTO, El hombre importante. (Agotado) 
Germani, GINO, Estructura social argentina. Estudio Preliminar de Jorge Graciarena.

GIBERTI, HoRACIO C. E., Historia económica de la ganadería argentina. $\left(5^{a}\right.$ edición, actualizada y corregida)

GonZÁleZ, JoAquín V., La tradición nacional. Prólogo de Bartolomé Mitre. (Agotado)

GutiérRez, Eduardo, Croquis y siluetas militares. Estudio Preliminar de Alvaro Yunque. (Agotado)

El Chacho. Estudio Preliminar de León Benarós. (Agotado)

La muerte de Buenos Aires. Estudio Preliminar de Juan Carlos Ghiano. (Agotado)

Los montoneros. Estudio Preliminar de León Benarós. (Agotado)

Holmberg, Eduardo L., Cuentos fantásticos. Estudio Preliminar de Antonio Pagés Larraya. (Agotado)

INGLÉs [UN], Cinco años en Buenos Aires: 1820-1821. Estudio Preliminar de Alejo B. González Garaño. (Agotado)

KORN, ALEJANDRO, Influencias filosóficas en la evolución nacional. Estudio preliminar de Gregorio Weinberg.

Leguizamón, Martiniano, De cepa criolla. Estudio Preliminar de Guillermo Ara. (Agotado)

Calandria. Estudio Preliminar de Juan Carlos Ghiano. (Agotado)

Montaraz. Estudio Preliminar de Roberto J. Payró. (Agotado)

Recuerdos de la tierra. Estudio Preliminar de Joaquín V. González. (Agotado)

Lima, FÉLIX, Entraña de Buenos Aires, Recopilación, Estudio Preliminar, Notas y Vocabulario de José Barcia.

MaC CANN, William, Viaje a caballo por las provincias argentinas. Traducción y Nota Preliminar de José Luis Busaniche. Con un Apéndice documental. (Agotado)

B.MACKINNON, L. B., La escuadra anglo-francesa en el Paraná (1842). Estudio Preliminar, Traducción y Notas de José Luis Busaniche. (Agotado).

Mansilla, Lucio V., Mis memorias. Infancia. Adolescencia. Estudio Preliminar de Juan Carlos Ghiano. (Agotado)

Entre nos. Estudio Preliminar de Juan Carlos Ghiano. (Agotado)

Mercante, Víctor [F. Scanavecchia], Los estudiantes. Estudio Preliminar de Amaro Villanueva. (Agotado)

Miers, JoHN, Viaje al Plata. 1819-1824. Estudio Preliminar, Traducción y Notas de Cristina Correa Morales de Aparicio. 
Mitre, BaRtolomé, Las ruinas de Tiahuanaco. Estudio Preliminar de Fernando Márquez Miranda. (Agotado)

Moreno, Francisco P., Viaje a la Patagonia Austral. 1876-1877. Estudio Preliminar y Notas de Raúl Rey Balmaceda. ( $3^{\mathbf{a}}$ edición).

Musters, George Chaworth, Vida entre los patagones. Estudio Preliminar y Notas de Raúl Rey Balmaceda. Traducción de Arturo Costa Alvarez. ( $3^{a}$ edición)

OBligado, PASTOR, Tradiciones Argentinas. Selección y Estudio Preliminar de Antonio Pagés Larraya. (Agotado)

Parish, Woodbine, Buenos Aires y las Provincias del Río de la Plata desde su descubrimiento y conquista por los españoles. Estudio Preliminar de José Luis Busaniche. Traducción y Notas de Justo Maeso. (Agotado)

PAYRó, RoBerto J., Teatro Completo. (Canción trágica; Sobre las ruinas; Marco Severi; El triunfo de los otros; Vivir quiero conmigo; Fuego en el rastrojo; Mientraiga; Alegría.) Estudio Preliminar de Roberto F. Giusti. (Agotado)

PETTORUTTI, EMILIO, Un pintor ante el espejo.

PONCE, ANIBAL, Sarmiento constructor de la Nueva Argentina y La vejez de Sarmiento. Estudio Preliminar de Luis F. Iglesias. (Agotado)

PRado, Comandante Manuel, Conquista de la pampa. Estudio Preliminar de Germán García. (Agotado)

ROJAS, RICARDO, El país de la selva. (Agotado)

ROMERO, JosÉ LUIS, El desarrollo de las ideas en la sociedad argentina del siglo XX. (Agotado)

Rossi, VICENTE, Cosas de negros. Estudio Preliminar y Notas de Horacio Jorge Becco. (Agotado)

- Teatro nacional rioplatense. Estudio Preliminar de J. A. de Diego. (Agotado)

RODRIGUEZ BUSTAMANTE, NORBERTO (editor), Debate parlamentario sobre la Ley Avellaneda. (Agotado)

Sainete Criollo [El]. (El amor de la estanciera, Anónimo del siglo XVIII; Los devotos, de Nemesio Trejo; Gabino el mayoral, de Enrique García Velloso; Fumadas, de Enrique Buttaro; A falta de pan, de Pedro E. Pico; El velorio del angelito, de Carlos R. de Paoli; El debut de la piba, de Roberto L. Cayol; La fonda del "pacarito", de Alberto Novión; La ribera, de Carlos Mauricio Pacheco; Entre bueyes no hay cornadas, de José González Castillo; El candidato del pueblo, de José A. Saldías; Tu cuna fue 
un conventillo, de Alberto Vacarezza; Babilonia, de Armando Discépolo.) Estudio Preliminar de Tulio Carella. (Agotado)

SÁnCheZ Gardel, Julio, Teatro. (Noche de luna; Después de misa; Las campanas; Los mirasoles; La montaña de las brujas.) Estudio preliminar de Juan Carlos Ghiano. (Agotado)

SARMIENTO, DOMINGo F., Viajes:

Tomo I, De Valparaíso a París. Estudio Preliminar de Alberto Palcos. (Agotado)

Tomo II, España e Italia, Estudio Preliminar de Norberto Rodríguez Bustamante. (Agotado)

Tomo III, Estados Unidos. Estudio Preliminar de Antonio de la Torre. (Agotado)

- Educación común: Estudio Preliminar de Gregorio Weinberg.

SAStre, M.; Alberdi, J. B.; GutiéRrez, J. M..; Echeverría, E., El Salón Literario, Estudio Preliminar de Félix Weinberg. (Agotado; reimpreso como Weinberg, Félix, El Salón Literario de 1837)

SCOBIE, JAMES R., La lucha por la consolidación de la nacionalidad argentina. 1852-1862. Traducción de Gabriela de Civiny. ( $2^{a}$ edición)

- Revolución en las pampas. Historia social del trigo argentino. 1860-1910. Traducción de Floreal Mazía. (2 ${ }^{a}$ edición)

- Buenos Aires, Del centro a los barrios. 1870-1910. Traducción de Mary Williams. ( $2^{a}$ edición)

TEDESCO, JuAn CARLOS, Educación y sociedad en la Argentina (18801945). Estudio Preliminar de Gregorio Weinberg. ( $2^{\mathrm{a}}$ edición)

The BRITISH PACKet, De Rivadavia a Rosas. Recopilación, Traducción, Notas y Estudio Preliminar de Graciela Lapido y Beatriz Spota de Lapieza Elli. (Agotado)

Weinberg, Félix, El Salón Literario de 1837. M. Sastre - J. B. Alberdi - J. M. Gutiérrez - E. Echeverría.

Weinberg, Gregorio, Mariano Fragueiro. Pensador olvidado. (Agotado; reimpreso como Estudio Preliminar de M. FRAGUEIRo, Cuestiones argentinas y Organización del crédito.)

WoOdBine Hinchliff, ThOMas, Viaje al Plata en 1861. Estudio Preliminar de Rafael Alberto Arrieta. Traducción y Notas de José Luis Busaniche. (Agotado)

Zeballos, Estanislao S., Callvucurá y la dinastía de los Piedra. Estudio Preliminar de Roberto F. Giusti. ( $3^{a}$ edición)

- Painé y la dinastía de los Zorros. 
- Relmu, reina de los Pinares.

- Callvucurá y la dinastía de los Piedra; Painé y la dinastía de los Zorros; y Relmu, reina de los Pinares. [En un solo volumen]. Estudio Preliminar de Roberto F. Giusti. (Agotado)

- La conquista de quince mil leguas. Estudio Preliminar de Enrique M. Barba. ( $2^{a}$ edición en prensa)

- Viaje al país de los araucanos. Estudio Preliminar de Andrés R. Allende. (Agotado)

ZinNY, ANTONIO, Estudios Biográficos. Estudio Preliminar de Narciso Binayán. (Agotado) 


\title{
Olimpio Pitango de Monalia
}

\author{
por EdUARDo L. HOLMBERG
}

\begin{abstract}
"El inusual polimorfismo de E. L. Holmberg, que conjuga el hombre de ciencia con el hombre de letras, emerge enmarcado por el concepto del intelectual, que está consciente del poder del pensamiento, para lograr transformaciones de orden público. Será el Holmberg intelectual, el que en una situación de oposición con el medio, contrapondrá a la estrechez y beatería, el pensamiento racional de la ciencia, misión didáctica desarrollada durante sus cuarenta años de enseñanza, a la que agregará la divulgación de los últimos adelantos científicos y la reflexión histórica sobre su país.

"Esta conjunción del intelectual con el científico aparece en la novela Olimpio Pitango de Monalia (1915), que según sus declaraciones fue "de todo lo que había escrito lo que más quería". (La Razón, 1927). Olimpio Pitango de Monalia es la obra totalizadora de su actividad creadora, ya que al participar de toda su vida, es Holmberg en toda su complejidad, en todos sus tiempos.

"En 1912, en Monalia una isla imaginaria, un sabio escritor, Olimpio Pjtango, provoca una verdadera revolución al exponer la necesidad de que su país se organice constitucionalmente para que pueda entrar en el concierto de las naciones más civilizadas, entre las que estaba la Argentina. Su plan de reforma tiende a que la nación tenga héroes, ruinas históricas, partidos políticos, constitución, todo lo que tenían los países más avanzados y que Monalia carecía hasta ese momento. Así fantásticamente se crea una situación falsa, se descubren ruinas históricas, se inventan héroes...

"Valiéndose de una multiplicidad ideológica y genérica, la novela desarrolla un universalismo filosófico que se completa con una visión carnavalesca del mundo. Contribuye a esta visión carnavalesca... las situaciones extremas y ridículas presentes en la novela - las disparatadas interpretaciones paleográficas, la invención de héroes y de documentos históricos- la pluralidad de los discursos opuestos, y la multiplicidad de géneros. Tono múltiple y dispar, integrado para crear la representación de un mundo al revés, el de la civilización actual..."
\end{abstract}

